WHC-EP-0659

\title{
Characterization of Past and Present Solid Waste Streams from 231-Z
}

\author{
J. A. Pottmeyer \\ D. S. DeLorenzo \\ M. I. Weyns-Rollosson \\ D. E. Berkwitz \\ E. J. Vejvoda
}

Los Alamos Technical Associates, Incorporated

D. R. Duncan

Westinghouse Hanford Company

Date Published

June 1993

Prepared for the U.S. Department of Energy Office of Environmental Restoration and Waste Management

\section{(2) Westinghouse P.O. Box 1970}

Hanford Company Riviland, Washington 99352

Hanford Operations and Engineering Contractor for the

U.S. Department of Energy under Contract DE-AC06-87RL10930 


\section{LEGAL DISCLAIMER}

This report was prepared as an account of work sponsored by an agency of the United States Government. Neither the United Elates Government nor any agency ithereof, nor any of their employees, nor any of their contractors. subcontractors or their employees, makes ary warranty, express or implied. or assumes any legal liability or responsibility for the accuracy, compleleness, or any third party's use or the results of such use of any information, apparatus, product, or process disclosed, or represents that its use would not infringe privately owned rights. Reference herein 10 any specific commercial product, process, or service by trade name. trademark, manufacturer, or otherwise, does not necessarily consitute or imply its endorsement, recommendation, or lavoring by the United States Government or any agency thereof or its contractors or subcontractors. The views and opinions of authors expressed herein do not necessarily state or reflect those of the United States Government or any agency thereof.

This report has been reproduced from the besl avallable copy. Ayallabie in paper copy and microfiche.

Available to the U.S. Department of Energy and its contraciors trom

Olfice of Scienulic and Technical information

P. O. Box 62

Oak Ridge, TN 37831

(615) 576.840

Avallaple 10 the public from the U.S. Department of Commerce National Technical information Service

5285 Port Royal Road

Soringfield, VA 22161

(703) 487.4650

Panted in the Unitod Stales oi America

DISCLM. . CHP $(1 \cdot 91)$ 
WHC-EP-0659

Document title:

Prepared by:

Approved by:
Characterization of Past and Present Solid Waste Streams from 231-z

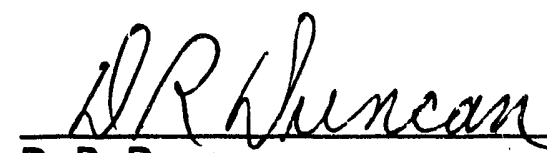

D. R. Duncan

$\frac{61 / 2 / 93}{\text { Date }}$

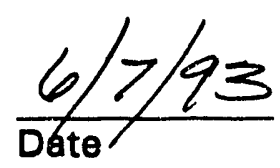

E. P. Martens, Manager

Waste Characterization

iii 


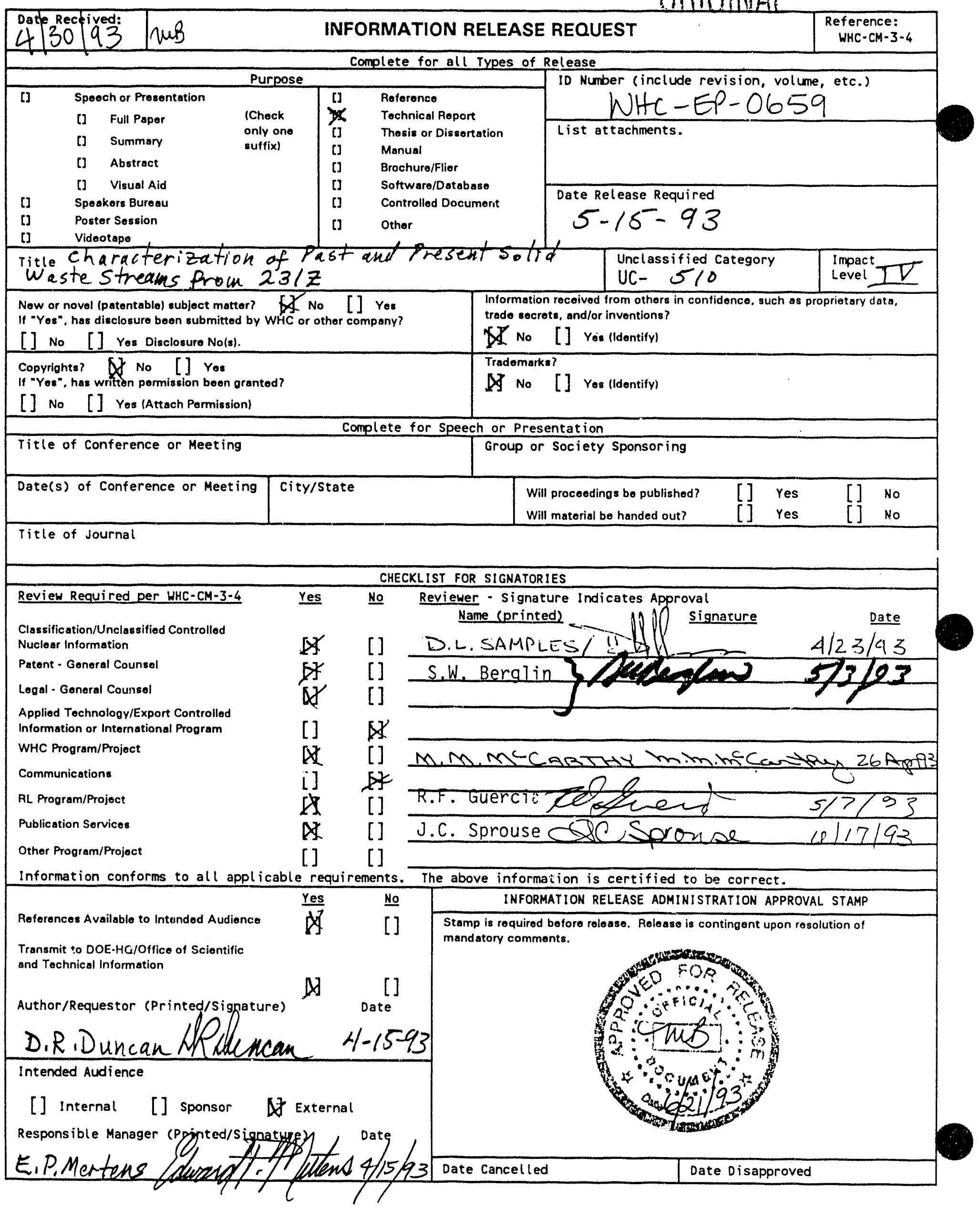


WHC-EP-0659

\section{ACKNOWLEDGEMENTS}

The following people generously shared their time and knowledge of 231-Z operations and solid waste generation:
V. C. Asmund
R. R. King
M. W. McCoy
F. F. Walters.

Also thanks are due to S. L. Gaistad and S. L. Claybrook for their assistance with the Solid Waste Information Tracking System database. 
WHC-EP-0659

This page intentionally left blank. 


\section{EXECUTIVE SUMMARY}

During the next two decades the transuranic (TRU) wastes now stored in the burial trenches and storage facilities at the Hanford Site are to be retrieved, processed at the Waste Receiving and Processing Facility, and shipped to the Waste Isolation Pilot Plant near Carlsbad, New Mexico for final disposal. Over $8 \%$ of the TRU waste to be retrieved for shipment to the Waste Isolation Pilot Plant has been generated at the Plutonium Metallurgy Laboratory (231-Z) Facility.

The purpose of this report is to characterize the radioactive solid wastes generated by $231-Z$ using process knowledge, existing records and oral history interviews. For most of the period of interest in this report, the $231-Z$ Facility was operated by Pacific Northwest Laboratory who ran the facility from 1965 until 1984 when its operation was assumed by Rockwell Hanford Operations. At the present time, much of $231-Z$ is being used as office space by Westinghouse Hanford Company.

The 231-Z Facility is located in the 200 West Area of the Hanford Site adjacent to the Plutonium Finishing Plant. Research and development programs utilizing plutonium have been conducted at $231-Z$ in the fields of physical metallurgy, property determination, alloy development, and process development. Section 2.0 provides further details of the 231-Z physical plant, facility operations, facility history, and current status.

The following are sources of solid waste generation at the 231-z Facility:

- General Weapons Development Program

- Process waste from gloveboxes

- Numerous classified research and development programs

- Advanced decontamination and decommissioning technologies, including sectioning, vibratory finishing, electropolishing, solution process, and small bench-scale work

- General laboratory procedures

- Foundry area 
- Housekeeping activities

- Four cleanout campaigns.

The types and estimated quantities of waste resuiting from these activities are discussed in detail in Section 3.0.

All solid wastes originating at 231-Z were packaged for onsite/offsite storage or disposal. The waste packages were designed to safely contain the waste during transportation and storage, and to meet the criteria of the storage/disposal unit. Waste packaging and reporting requirements have undergone significant changes throughout the history of 231-Z. Current and historical packaging and handling procedures for radioactive wastes at 231-Z Facility are provided in Section 4.0.

Information on the radioactive wastes generated at $231-\mathrm{Z}$ can be found in a number of existing documents and databases. The most important of these are the Solid Waste Information and Tracking System database and Solid Waste Burial Records. Facility personnel also provide excellent information about past waste generation and the procedures used to handle that waste. Section 5.0 was compiled using these sources to characterize the radioactive wastes, especially TRU wastes, generated at 231-Z.

Between 1969 and 19883,971 containers of radioactive solid waste were generated at $231-\mathrm{Z}$. These containers represent over $700,000 \mathrm{~kg}(1,543,209.8 \mathrm{lb})$ of waste occupying $2,470 \mathrm{~m}^{3}\left(87,226.75 \mathrm{ft}^{3}\right)$ of space. Section 5.0 provides an indepth look at this waste including the following:

- Weight and volume of the waste

- Container types and numbers

- Physical description of the waste

- Radiological components

- Hazardous constituents

- Current stiorage/disposal locations. 


\section{CONTENTS}

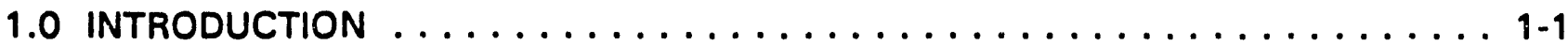

1.1 PURPOSE ............................. 1 .1

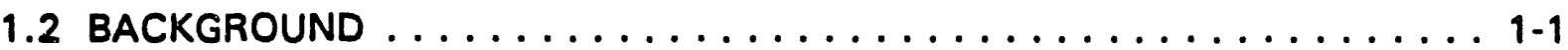

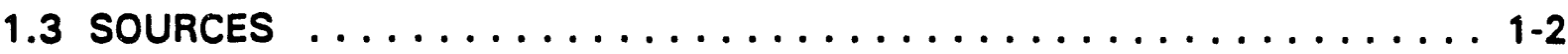

1.4 SCOPE ............................... 1-3

2.0 DESCRIPTION OF THE $231-Z$ BUILDING $\ldots \ldots \ldots \ldots \ldots \ldots \ldots \ldots \ldots$

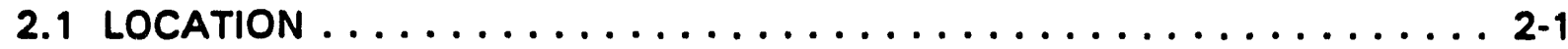

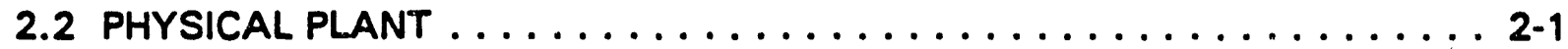

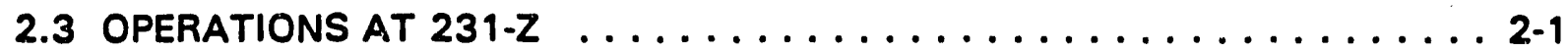

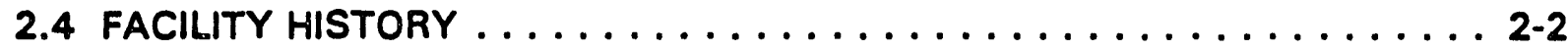

2.5 CURRENT STATUS . . . . . . . . . . . . . . . . . . 2-3

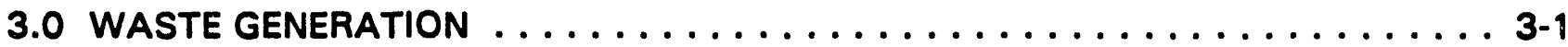

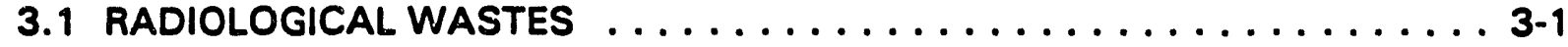

3.1.1 Gaseous Radioactive Wastes . . . . . . . . . . . . . . 3-1

3.1 .2 Liquid Radioactive Waste . . . . . . . . . . . . . . 3-1

3.1.3 Solid Radioactive Wastes . . . . . . . . . . . . . . . 3-2

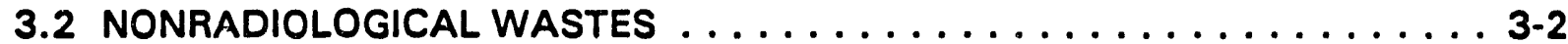

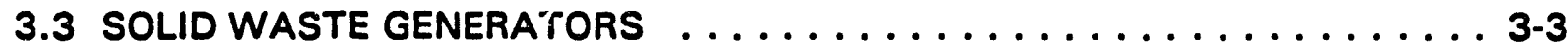

3.3.1 Types of TRU Waste Generated . . . . . . . . . . . . . . . . 3-3

3.3.2 Types of Low-Level Waste . . . . . . . . . . . . . . . . . 3-4

3.3.3 Waste Generated by Cleanout Campaigns . . . . . . . . . . . . . 3-4

4.0 SOLID WASTE HANDLING PRACTICES AND PROCEDURES . . . . . . . . . . . 4-1

4.1 HISTORICAL SOLID WASTE CHARACTERIZATION . . . . . . . . . . . . 4-1

4.2 HISTORICAL WASTE PACKAGING AND HANDLING PROCEDURES $\ldots \ldots$. . 4-2

4.3 CURRENT WASTE HANDLING AND PACKAGING . . . . . . . . . 4-3

5.0 CHARACTERIZATION OF RETRIEVABLY STORED

SOLID WASTE GENERATED BY $231-Z \ldots \ldots \ldots \ldots \ldots \ldots \ldots \ldots \ldots \ldots$

5.1 SUMMARY OF $231-Z$ WASTE GENERATION . . . . . . . . . . . 5-1

5.1 .1 Waste Stored in 55-Gallon Steel Drums . . . . . . . . . . . . 5-1

5.1.2 Waste Stored in Containers Other Than 55-Gallon Steel Drums . . . . . . . . . . . . . . . . . . . . . 5-3

5.1.3 Summary of Waste Generation Rates at

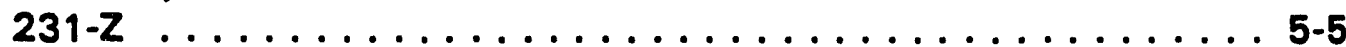

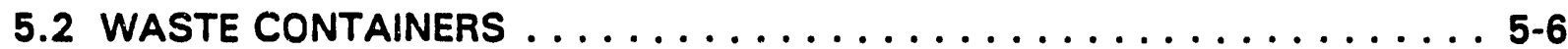

5.2.1 TRU Waste Containers . . . . . . . . . . . . . . . . 5-6

5.2.2 Non-TRU Waste Containers . . . . . . . . . . . . . . . . . . 5-6

5.3 TRU WASTE STORAGE LOCATIONS . . . . . . . . . . . . . . . . 5-7

5.4 PHYSICAL CONTENTS OF TRU WASTE CONTAINERS $\ldots \ldots \ldots \ldots \ldots$

5.5 RADIOLOGICAL DESCRIPTION OF $231-Z$ SOLID WASTE $\ldots \ldots \ldots \ldots \ldots$

5.6 RADIOACTIVE ISOTOPES PRESENT IN $231-Z$ SOLID WASTE $\ldots \ldots \ldots$

5.7 HAZARDOUS CONSTITUENTS OF SOLID WASTE GENERATED BY 231-Z . . 5-9

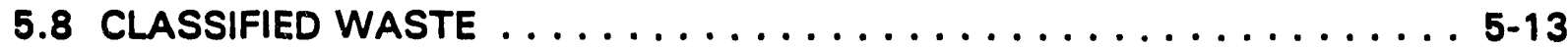




\section{CONTENTS (cont.)}

\section{APPENDIXES}

A DATA ON 231-Z WASTE GENERATION FROM THE SOLID WASTE INFORMATION TRACKING SYSTEM . . . . . . . . . . . . . . . . . A-1

A. 1 CONTAINER NUMBER AND WEIGHT OF TRU WASTE IN 55-GALLON DRUMS BY WASTE TYPE

A.2 231-Z TRU WASTE CONTAINERS SORTED BY CONTAINER DESCRIPTION, SIZE, YEAR, AND PRIMARY WASTE TYPE

A.3 231-Z NON-TRU WASTE CONTAINERS SORTED BY CONTAINER DESCRIPTION, SIZE, YEAR, AND PRIMARY WASTE TYPE . . . . . . . . A-23

A.4 RADIOLOGICAL DATA FOR TRU WASTE CONTAINERS SORTED BY DATE, PRIMARY WASTE TYPE, AND STORAGE FACILITY $\ldots \ldots \ldots \ldots \ldots \ldots \ldots$. . . A-35

A.5 PHYSICAL CONTENTS DESCRIPTION FOR 231-Z 55-GALLON DRUMS CONTAINING TRU WASTE SORTED BY DATE, PRIMARY WASTE TYPE, AND STORAGE FACILITY . . . . . . . . . . . . . A A-43

A.6 PHYSICAL CONTENTS DESCRIPTION FOR 231-Z TRU WASTE CONTAINERS OTHER THAN 55-GALLON DRUMS SORTED BY DATE, PRIMARY WASTE TYPE, AND STORAGE FACILITY $\ldots \ldots \ldots \ldots$. . . A-49

A.7 HAZARDOUS CONSTITUENTS OF 55-GALLON DRUMS CONTAINING TRU WASTE . . . . . . . . . . . . . . . . A A-55

A.8 HAZARDOUS CONSTITUENTS OF TRU WASTE CONTAINERS OTHER THAN $55-G A L L O N$ DRUMS . . . . . . . . . . . . . . . A A-61

A.9 ISOTOPES LISTED IN 55-GALLON DRUMS CONTAINING TRU WASTES . A-67

A.10 ISOTOPES LISTED IN TRU CONTAINERS OTHER THAN 55-GALLON DRUMS ..................... 
WHC-EP-0659

LIST OF FIGURES

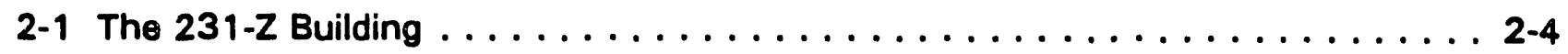

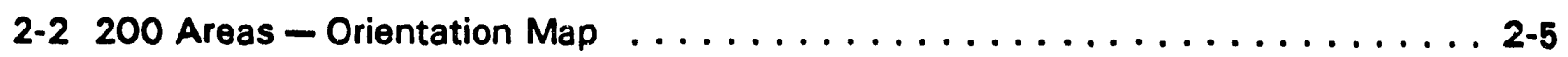

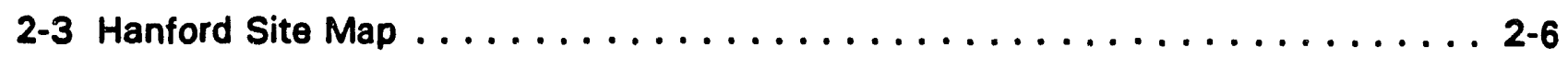

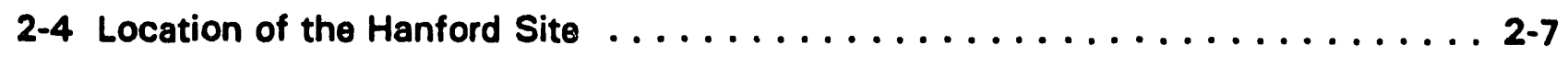

2.5 Layout of $231-z$ Building from 1960 to early 1970's . . . . . . . . . . . . 2-8

2-6 Current Layout of the 231-Z Building

First Floor. ............................... 2-9

2-7 Location of Waste Items in PNL Isolated Facilities,

231-z Building . . . . . . . . . . . . . . . . . . . . . . 2-10

5-1 55-Gallon Drum Waste Count Generated by 231-Z Annually . . . . . . . . . 5-14

5-2 Percentage of $231-Z$ TRU/Non-TRU 55-Gallon Drums $\ldots \ldots \ldots \ldots \ldots$. . . . . 5-15

5-3 Weight of 55-Gallon Drum Waste Generated by 231-z Annually . . . . . . . 5-16

5-4 Weight Percentage of 231-z 55-Gallon Drums . . . . . . . . . . . . 5-17

5-5 Volume of 55-Gallon Drum Waste Generated by 231-Z Annually . . . . . . . . 5-18

5-6 Volume Percentage of $231-z$ 55-Gallon Drums $\ldots \ldots \ldots \ldots \ldots \ldots$. . . . . . 5-19

5-7 Other Container Waste Count Generated by 231-Z Annually . . . . . . . . . . 5-20

5-8 Percentage of 231-Z TRU/Non-TRU Other Containers . . . . . . . . . . . 5-21

5-9 Weight of Other Containers Generated by 231-z Annually . . . . . . . . . . 5-22

5-10 Weight Percentage of Other Containers

Generated by $231-z$ Annually . . . . . . . . . . . . . . . . . . . . 5-23

5-11 Volume of Other Containers Generated by $231-z$ Annually . . . . . . . . . . . . 5-24

5-12 Volume Percentage of Other Containers

Generated by $231-z$ Annually . . . . . . . . . . . . . . . . . . 5-25

5-13 Total Number of Waste Containers Generated by 231-Z Annually . . . . . . . 5-26

5-14 Total Weight of Waste Generated by 231-z Annually . . . . . . . . . . . 5-27 
WHC-EP-0659

\section{LIST OF FIGURES (cont.)}

5-15 Total Volume of Waste Generated by $231-z$ Annually $\ldots \ldots \ldots \ldots \ldots \ldots$ 5-28

5-16 Grams of TRU Waste Generated by $231-z$ Annually . . . . . . . . . . . 5-29 
WHC-EP-0659

\section{LIST OF TABLES}

2-1 Remaining TRU Waste Inventory at $231-Z \ldots \ldots \ldots \ldots \ldots \ldots$. . . . . . . . . 1

4- १. TRU Storage Requirements for the Hanford Site . . . . . . . . . . . . . 4-5

5-1 TRU Waste Generated at 231-Z by Container Type and Year . . . . . . . . . . 5-29

5-2 Non-TRU Waste Generated at 231-Z by Container Type and Year . . . . . . . 5-32

$5-3231-Z$ Waste Summary Data for $55-G a l l o n$ Drums $\ldots \ldots \ldots \ldots$. . . . . . . 5-36

5-4 231-Z Waste Summary Data for Containers Other Than 55-Gallon Drums . . . . 5-37

5-5 231-Z Burial Boxes From 1980 and $1981 \ldots \ldots \ldots \ldots \ldots \ldots$

5-6 231-Z TRU Waste in 55-Gallon Drums - Drum Count by Storage Location . . . . . . . . . . . . . . . . . . . . . . . 5-39

5-7 231-Z TRU Waste in Containers Other Than 55-Gallon Drums Container Count by Siorage Location . . . . . . . . . . . . . . . . . . . . . 5-39

5-8 Distribution and Percentage of TRU 55-Gallon Drum Physical

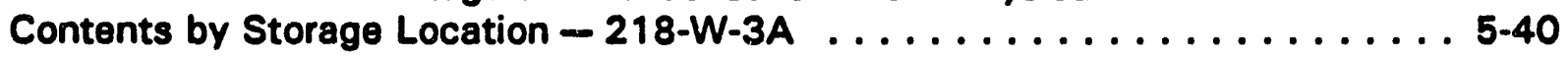

5-9 Distribution and Percentage of TRU 55-Gallon Drum Physical Contents by Storage Location $-218-W-4 B \ldots \ldots \ldots$. . . . . . . . . . . . 5-40

5-10 Distribution and Percentage of TRU 55-Gallon Drum Physical Contents by Storage Location $-218-W-4 C \ldots \ldots \ldots$. . . . . . . . . . . 5-41

5-11 Distribution and Percentage of TRU Containers Other Than 55-Gallon Drums Physical Contents by Storage Location - 218-W-3A

5-12 Distribution and Percentage of TRU Containers Other Than 55-Gallon Drums Physical Contents by Storage Location - 218-W-4B

5-13 Distribution and Percentage of TRU Containers Other Than 55-Gallon Drums Physical Contents by Storage Location - 218-W-4C

5-14 231-Z TRU Waste in 55-Gallon Drums - Total Grams TRU by Storage Location . . . . . . . . . . . . . . . . . . . . . 5-43

5-15 231-Z TRU Waste in Containers Other Than 55-Gallon Drums Total Grams TRU by Storage Location 


\section{LIST OF TABLES (cont.)}

5-16 231-Z TRU Mixed Waste in 55-Galion Drums - Drum Count by Storage Location . . . . . . . . . . . . . . . . . . . . . . . . . . 5-44

5-17 Number and Percentage of 231-Z TRU 55-Gallon Drums Containing Hazardous Constituents by Storage Location $-218-W-4 B \ldots \ldots \ldots \ldots$. . . . . 5-45

5-18 Number and Percentage of 231-Z TRU 55-Gallon Drums Containing Hazardous Constituents by Storage Location $-218-W-4 C \ldots \ldots \ldots \ldots$. . . . 5-45

5-19 Hazardous Substances Known or Suspected to be in the 231-Z Solid Waste System . . . . . . . . . . . . . . . . . . . . . . . . . . . . 5 546

5-20 Summary of Information from Solid Waste Storage Disposal Records for TRU Wastes with Hazardous Contents from PNL 231-Z . . . . . . . . . 5-49

5-21 Summary of Information from Solid Waste Storage Disposal Records for Low-Level Waste with Hazardous Contents from PNL 231-Z . . . . . . . . . 5-50 


\section{LIST OF TERMS}

\begin{tabular}{|c|c|}
\hline $\begin{array}{l}231-Z \\
\text { AEC } \\
\text { D\&D } \\
\text { DMA } \\
\text { DOE } \\
\text { DOT } \\
\text { ECOlogY } \\
\text { EPA } \\
\text { FFTF } \\
\text { FRP } \\
\text { HEPA } \\
\text { HMS } \\
\text { HVAC } \\
\text { IAD } \\
\text { LLW } \\
\text { MW } \\
\text { NDA } \\
\text { NRC } \\
\text { ORM } \\
\text { PCB } \\
\text { PFP } \\
\text { PIN } \\
\text { PNL } \\
\text { PUREX } \\
\text { R-SWIMS } \\
\text { R\&D } \\
\text { RCRA } \\
\text { REDOX } \\
\text { RHO } \\
\text { RMO } \\
\text { RTL } \\
\text { SAR } \\
\text { SGSAS } \\
\text { SNM } \\
\text { S/S } \\
\text { SWBR } \\
\text { SWITS } \\
\text { SWSDR } \\
\text { TRU } \\
\text { WHC } \\
\text { WIPP } \\
\text { WRAP }\end{array}$ & $\begin{array}{l}\text { Plutonium Metallurgy Laboratory } \\
\text { U.S. Atomic Energy Commission (now DOE) } \\
\text { decontamination and decommissioning } \\
\text { Division of Military Applications } \\
\text { U.S. Department of Energy } \\
\text { U.S. Department of Transportation } \\
\text { Washington State Department of Ecology } \\
\text { U.S. Environmental Protection Agency } \\
\text { Fast Flux Test Facility } \\
\text { fiberglass reinforced polyester } \\
\text { high efficiency particulate air (filter) } \\
\text { Hanford Meteorology Station } \\
\text { heating, ventilation, and air conditioning } \\
\text { immediate action directive } \\
\text { low-level waste } \\
\text { mixed waste } \\
\text { nondestructive assay } \\
\text { U.S. Nuclear Regulatory Commission } \\
\text { other regulated material } \\
\text { polychlorinated biphenyl } \\
\text { Plutonium Finishing Plant } \\
\text { personal identification number } \\
\text { Pacific Northwest Laboratory } \\
\text { Plutonium-Uranium Extraction (Plant) } \\
\text { Richland Solid Waste Information Management Systems } \\
\text { research and development } \\
\text { Resource Conservation and Recovery Act of } 1976 \\
\text { Reduction Oxidation (plant) } \\
\text { Rockwell Hanford Operations } \\
\text { Radiation Monitoring Office } \\
\text { Research Technology Laboratory } \\
\text { safety analysis report } \\
\text { Segmented Gamma Scan Assay System } \\
\text { special nuclear material } \\
\text { sectioning and size reduction } \\
\text { Solid Waste Burial Record } \\
\text { Solid Waste Information and Tracking System } \\
\text { Solid Waste Storage and Disposal Record } \\
\text { transuranic } \\
\text { Westinghouse Hanford Company } \\
\text { Waste Isolation Pilot Plant } \\
\text { Waste Receiving and Processing Facility }\end{array}$ \\
\hline
\end{tabular}


WHC-EP-0659

This page intentionally left blank. 


\subsection{INTRODUCTION}

\subsection{PURPOSE}

The purpose of this report is to characterize, as far as possible, the solid waste generated by the Plutonium Metallurgy Laboratory (231-Z) Facility since its construction in 1944. Solid waste as defined in this document is any containerized or self-contained material that has been declared waste. This characterization is of particular interest in the planning of transuranic (TRU) waste retrieval and repackaging operations, because 231-Z has generated approximately $8.2 \%$ of the total volume of TRU waste currently stored at the Hanford Site. Liquid effluents are discussed briefly to provide a more complete picture of waste production at $231-\mathrm{Z}$.

\subsection{BACKGROUND}

Since 1944 the production of defense-related materials at the Hanford Site has generated radioactive wastes. The bulk of these wastes have been disposed of or stored in the 200 East Area and 200 West Area burial grounds and waste storage facilities.

In the period between 1944 and 1970 both TRU and low-level wastes (LLW) were disposed of in shallow land trenches with no attempt to segregate these materials by their chemical or radioactive natures. In 1970 the U.S. Atomic Energy Commission (AEC, now the U.S. Department of Energy [DOE]) directed that AEC sites segregate "waste with known or detectable contamination of transuranium nuclides" from other waste types (Immediate Action Directive [IAD] 0511-21 [AEC 1970]). TRU radionuclides are those with an atomic number greater than 92. The AEC further directed that these wastes be packaged and stored as contamination-free packages for at least 20 years. The 20-year interim storage period was to allow time to study permanent disposal options for TRU contaminated wastes.

The IAD did not provide a detailed definition for TRU waste in 1970. AEC contractors implemented the IAD to the best of their ability with the instrumentation then available. In 1973 the AEC manual (AEC 1973) further defined TRU waste as material contaminated with certain alpha-emitting radionuclides with half-lives greater than 20 years, and activity greater than $10 \mathrm{nCi} / \mathrm{g}$. The radionuclides included were ${ }^{233} \mathrm{U}$ and its daughter products, as well as plutonium and transplutonium nuclides, with the exception of ${ }^{238} \mathrm{Pu}$ and ${ }^{241} \mathrm{Pu}$. In 1982 the TRU waste segregation limits were raised to $100 \mathrm{nCi} / \mathrm{g}$ by DOE Order 5820.1, Management of Transuranic Material (DOE 1982).

In addition to radioactive materials, Hanford Site production plants and support operations used a wide variety of chemicals. Many of these chemicals are currently classified as dangerous or hazardous by the U.S. Environmental Protection Agency (EPA) and the Washington State Department of Ecology (Ecology). When dangerous or hazardous wastes are found in radioactive wastes they are termed "mixed" wastes (MW). 
During the time much of the MW at the Hanford Site was generated, there were no definitions or regulations governing the storage, disposal, or documentation of $M W$. In 1987 the DOE issued a mixed by-product ruling stating that the hazardous components of MW are regulated by the Resource Conservation and Recovery Act of 1976 (RCRA) (10-CFR-962). In November 1987 the EPA authorized Ecology to regulate the hazardous constituents of MW on the Hanford Site.

During the next two decades the TRU waste now stored in the burial trenches and storage facilities is to be retrieved, processed at the Waste Receiving and Processing (WRAP) Facility, and shipped to the Waste Isolation Pilot Plant (WIPP) near Carisbad, New Mexico for final disposal. Over $\mathbf{8 \%}$ of the total volume of TRU waste to be retrieved for shipment to WIPP has been generated by the 231-Z Facility.

\subsection{SOURCES}

Data for this study were compiled from a variety of sources. Each of the major sources used is listed in following paragraphs with a few explanatory notes. Greater detail on each of the data sources can be found in the body of this document as the information from each is discussed.

Documents that describe $231-Z$ processes and experiments, including the Safety Analysis Report (SAR), 231-Z Building (BNWL 1970), and the 200 Areas Fact Book (RHO 1985) were used to determine the solid wastes that may have been generated at 231-Z during its 42-year history.

Documents that describe 231-Z Waste Packaging and Handling Procedures, including the Hanford Site Radioactive Solid Waste Acceptance Criteria (Willis and Triner 1991), were used to describe packaging and handling practices.

Interviews with current and former 231-Z personnel were used to gather information regarding unusual waste contents and historical waste handling and packaging procedures.

Characterization data were derived primarily from the Solid Waste Information and Tracking System (SWITS) database. The SWITS database was created in 1991, primarily with the solid waste data from the Richland Solid Waste Information Management System (R-SWIMS). The SWITS database contains information about TRU and low-level radioactive wastes, buried or stored in the 200 Areas since 1970 . Originally data in SWITS were taken from Solid Waste Burial Records (SWBRs) and their replacements, the Solid Waste Storage and Disposal Records (SWSDRs). Both SWBRs and SWSDRs, which will be jointly referred to as "burial records" in this document, often contain supplementary forms such as shipment manifests and U.S. Nuclear Regulatory Commission (NRC) 741 Forms.

Hazardous waste components were determined using information from the SWITS database, SWBRs, SWSDRs, and personnel interviews. Additional information was obtained from Reactive and Unstable Chemicals in Transuranic Retrievable Waste at the 
Hanford Site, WHC-EP-0603 (Reddinger 1992) and an internal report examining hazardous components of solid waste.

\subsection{SCOPE}

The major sections of this document and the topics they cover are outlined briefly in following paragraphs. Because of the number of tables and figures included in this report, they appear at the end of each section.

Section 2.0 provides a brief description of the $231-\mathrm{Z}$ physical plant and the operations that occurred there. A short history of the significant occurrences and changes at $231-Z$ follows this description.

Section 3.0 identifies the solid waste streams that arose from $231-\mathrm{Z}$ activities. The types and amounts of solid waste that may have been generated from each of the waste streams are estimated.

Section 4.0 discusses the waste handling and packaging procedures used at 231-Z. Historical changes in waste handling, packaging, and recordkeeping are also reviewed in this section.

Section 5.0 contains the results of a search for actual waste container data including database searches, literature review, and personnel interviews. This section describes what is known about the physical, radiological, and hazardous characteristics of the radioactive solid waste from $231-\mathrm{Z}$.

Section 6.0 lists the references used in the compilation of this report.

Appendix A contains the original SWITS data runs that form the basis for most of the tables and figures found in Section 5.0. 
WHC-EP-0659

This page intentionally left blank. 


\subsection{DESCRIPTION OF THE 231-Z BUILDING}

The 231-Z Building was used for metallurgical research on plutonium and its alloys. Fabrication development work was also conducted on plutonium parts and reactor fuels containing plutonium or other alpha emitting components. Large quantities of plutonium, from 100 to $200 \mathrm{~kg}$ (220.46 to $440.92 \mathrm{lb})$, were routinely handled and stored at this facility. Nearly all operations involved plutonium metal in the dry or unmoderated state. A photograph of the 231-Z Building is shown in Figure 2-1.

\subsection{LOCATION}

The 231-Z Building is located in the 200 West Area of the Hanford Site adjacent to the Plutonium Finishing Plant (PFP). Orientation of the 231-Z Building with respect to other installations in the 200 Areas is shown in Figure 2-2. The 200 West Area is situated near the center of the Hanford Site. The Hanford Site occupies $1,527,707.5 \mathrm{~m}^{2}$ (365,000 acres) of arid steppe in the southeastern part of Washington State, approximately $72.42 \mathrm{~km}$ (45 miles) north of the Oregon border (Figure 2-4).

\subsection{PHYSICAL PLANT}

The 231-Z Facility is a two-story building of reinforced concrete and concrete block construction. The first floor has an area of approximately $2508.3 \mathrm{~m}^{2}\left(27,000 \mathrm{ft}^{2}\right)$. During the period when the solid waste discussed in this report was generated, about $492.37 \mathrm{~m}^{2}$ $\left(5,300 \mathrm{ft}^{2}\right)$ of this floor was used for building service machinery, with the remaining $2,015.93 \mathrm{~m}^{2}\left(21,700 \mathrm{ft}^{2}\right)$ used for laboratory area. The upper floor is essentially one large open bay with a floor area of approximately $2183.15 \mathrm{~m}^{2}\left(23,500 \mathrm{ft}^{2}\right)$. Until 1987 this floor was used for piping, ventilation ducts, filter cages, miscellaneous storage, and supporting facilities (vacuum pumps, hydraulic equipment, etc.) for equipment on the first floor.

In addition to the main laboratory structure, there is a $278.7 \mathrm{~m}^{2}\left(3,000 \mathrm{ft}^{2}\right)$ office extension of concrete block construction. This office building is attached to the laboratory structure and is isolated by air locks. The functional arrangement of the 231-Z Building during the period between 1960 and the early 1970's is shown in Figure 2-4. Figure 2-5 shows the current layout of the 231-Z Building's first floor.

\subsection{OPERATIONS AT 231-2}

The 231-Z Facility was operated by DuPont from 1944 until 1947, General Electric from 1947 until 1965, and what is now the Pacific Northwest Laboratory (PNL) from 1965 until 1984 when its operation was taken over by Rockwell Hanford Operations (RHO). Currently it is used primarily for office space by the Westinghouse Hanford Company (WHC), which succeeded RHO in 1986 and is now the Hanford Site operations and engineering contractor. 
Plutonium research and development has been conducted at 231- $Z$ in the areas of physical metallurgy, property determination, alloy development, and process development. Research and development activities included melting, alloying, casting, machining, rolling, pressing, forging, electron beam welding, and vapor deposition of plutonium and plutonium alloys. Metallurgy research operations included metallography, electron microscopy, dilatometry, density determination, electron microprobe, $X$-ray diffraction, high temperature and high speed properties determination, and room temperature property determination. The operations performed at $231-\mathrm{Z}$ involved quantities of plutonium ranging from small metallographic samples weighing a fraction of one gram to large parts weighing in the multi-kilogram range.

\subsection{FACILITY HISTORY}

The 231-z Building was one of the original chemical separation facilities on the Hanford Site. Beginning operations in 1944, it was the location for the final step in a processing series to separate plutonium from irradiated fuel slements. The end produrt of this operation, a highly concentrated plutonium nitrate solution, was then shipped to the Los Alamos National Laboratory. This mission for $231-z$ lasted through 1955 when the newly constructed PFP, also referred to as 234-5Z, assumed this role.

In 1956 the 231-Z Building began to evolve into a research facility, and process development and plutonium metallurgy personnel moved into the laboratory. The primary mission of the research team was to support nuclear device research and development. The special laboratory was outfitted with a double-filter exhaust system; contaminated drain systems; emergency detection and alarm equipment; and a special heating, ventilation, and air conditioning (HVAC) system for radiation zone work.

One of the jobs of the $231-Z$ research team was to build one-of-a-kind nuclear devices for testing. The device fabrication was done using designs provided by Lawrence Livermore National Laboratory. After fabrication and assembly of prototype devices, the devices were sent to Nevada for testing. After each Nevada test, there was a written evaluation of the device performance and of the personnel involved in its design and construction.

Design agency support at $231-Z$ increased following the Rocky Flats fire in 1969. Sponsorship of the work at $231-Z$ was 80 to $85 \%$ AEC, Division of Military Applications (DMA): 10\% AEC Division of Physical Research; and 5 to $10 \%$ other, including services to other Hanford Site programs.

One of the successes of the research team at 231-Z was the development of a sputtering process. With the successful demonstration of sputtering in 1973, the Process Development Laboratory was remodeled to accommodate the new process. During the modification, a substantial amount of equipment and fixtures were torn out and disposed of as solid waste.

In January 1975 PNL was advised by the DMA of its intention to phase out the General Weapons Development Program. The sponsor subsequently gave $\$ 4.8$ million to the 231-Z program to tear out gloveboxes and refurbish the building. The majority of the 
waste went out with the glovebox changeout. Approximately 56 gloveboxes and 9 pieces of large equipment were packaged in 19 fiberglass reinforced polyester (FRP) burial boxes during 1976, 1977, and 1978. These boxes were not moved to the burial grounds until 1980.

In 1978, as DMA work phaseout continued, new work began in 231-Z to develop advanced decontamination and decommissioning (D\&D) technologies. This project, which ran from 1978 until 1981 and was cleaned up between 1983 and 1985, was separated into the following tasks:

- Sectioning - Done in a large walk-in glovebox that contained manipulators, a plasma cutting torch, and cranes

- Vibratory Finishing - Done in a large vibrating tub and was used for polishing, deburring, and cleaning a variety of items

- Electropolishing - Used rinse tanks for decontamination

- Solution Processing - Used an evaporator in a process that included ion exchange and solidification

- Other - Small, bench-scale work, including metallography.

A sacond major cleanout campaign ran from 1982 to 1984. Its primary mission was to continue disposing of waste stored in the $231-Z$ vaults. In 1982 all remaining operations were moved to the Research Technology Laboratories, RTL-2, and the Decontamination Program was terminated.

In 1984 a major portion of the 231-Z Building was transferred to RHO, along with landlord responsibilities for the entire facility. PNL maintained a small portion of the facility on a rental basis for limited research and development (R\&D) work until 1985. At that time it was decided to terminate all R\&D work in 231-Z. Two more cleanout campaigns in 1985 and 1986 were undertaken to continue the disposal of waste stored in the 231-Z vaults.

\subsection{CURRENT STATUS}

At the present time, much of the 231-Z Facility is being used as office space. The building still contains an inventory of TRU contaminated equipment and waste containers. These remaining waste items are listed in Table 2-1. A map of the areas where these waste items are located can be found in Figure 2-6. 
Figure 2-1. The 231-Z Building.

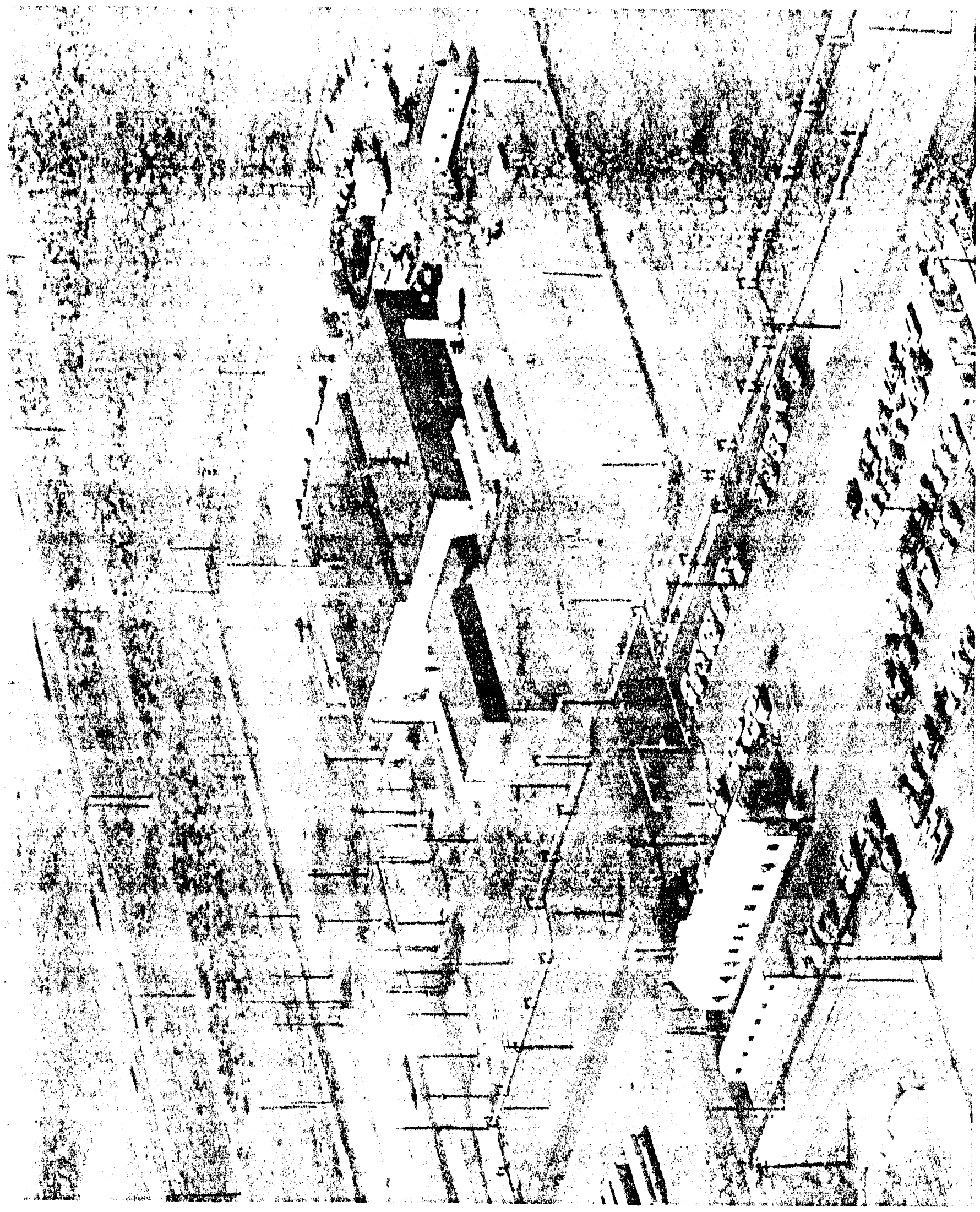




\section{WHC-EP-0659}

Figure 2-2. 200 Areas - Orientation Map.
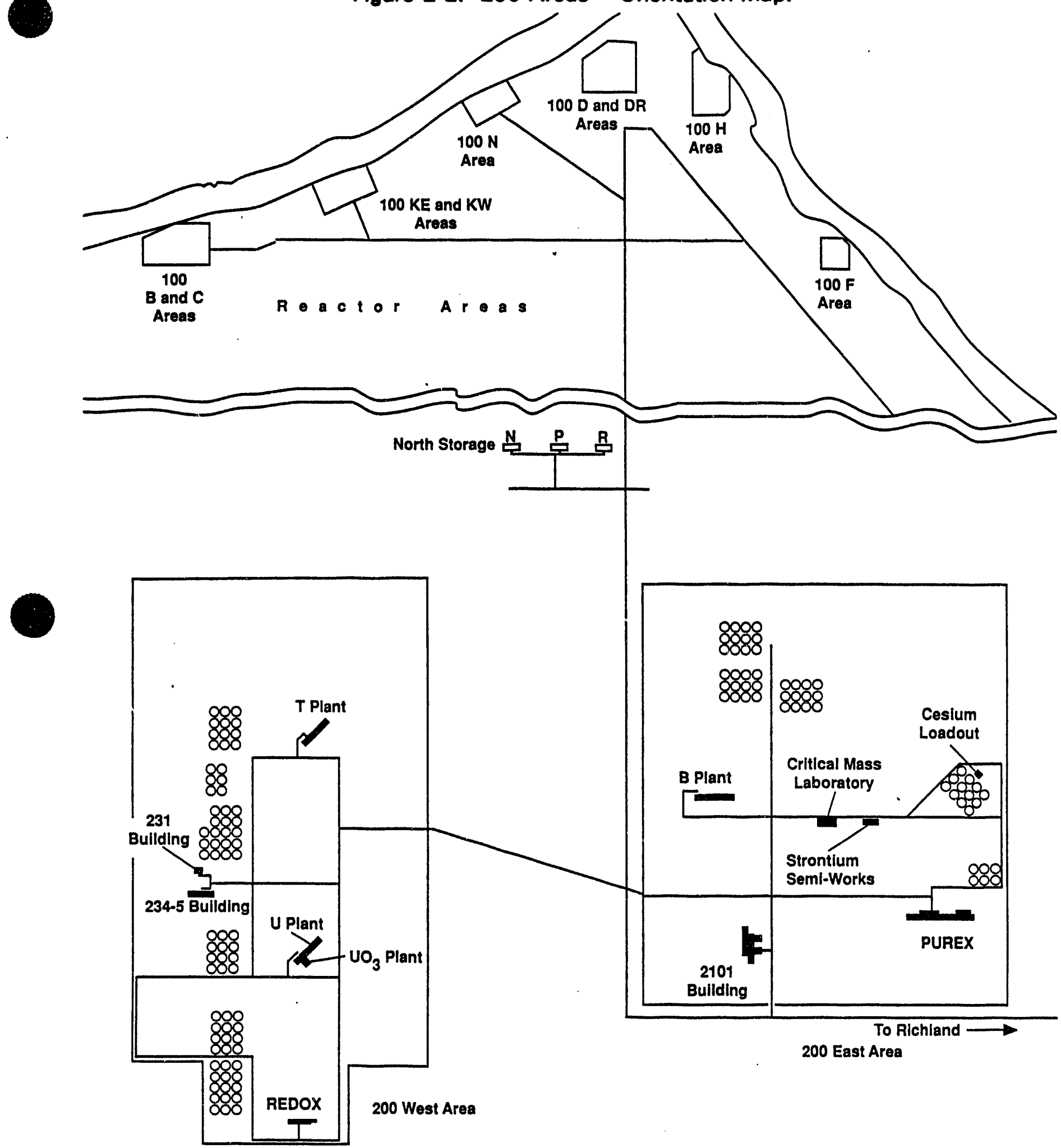

PUREX = Plutonium-Uranlum Extraction (Plant)

REDOX = Reduction Oxidation (Plant) 
Figure 2-3. Hanford Site Map.

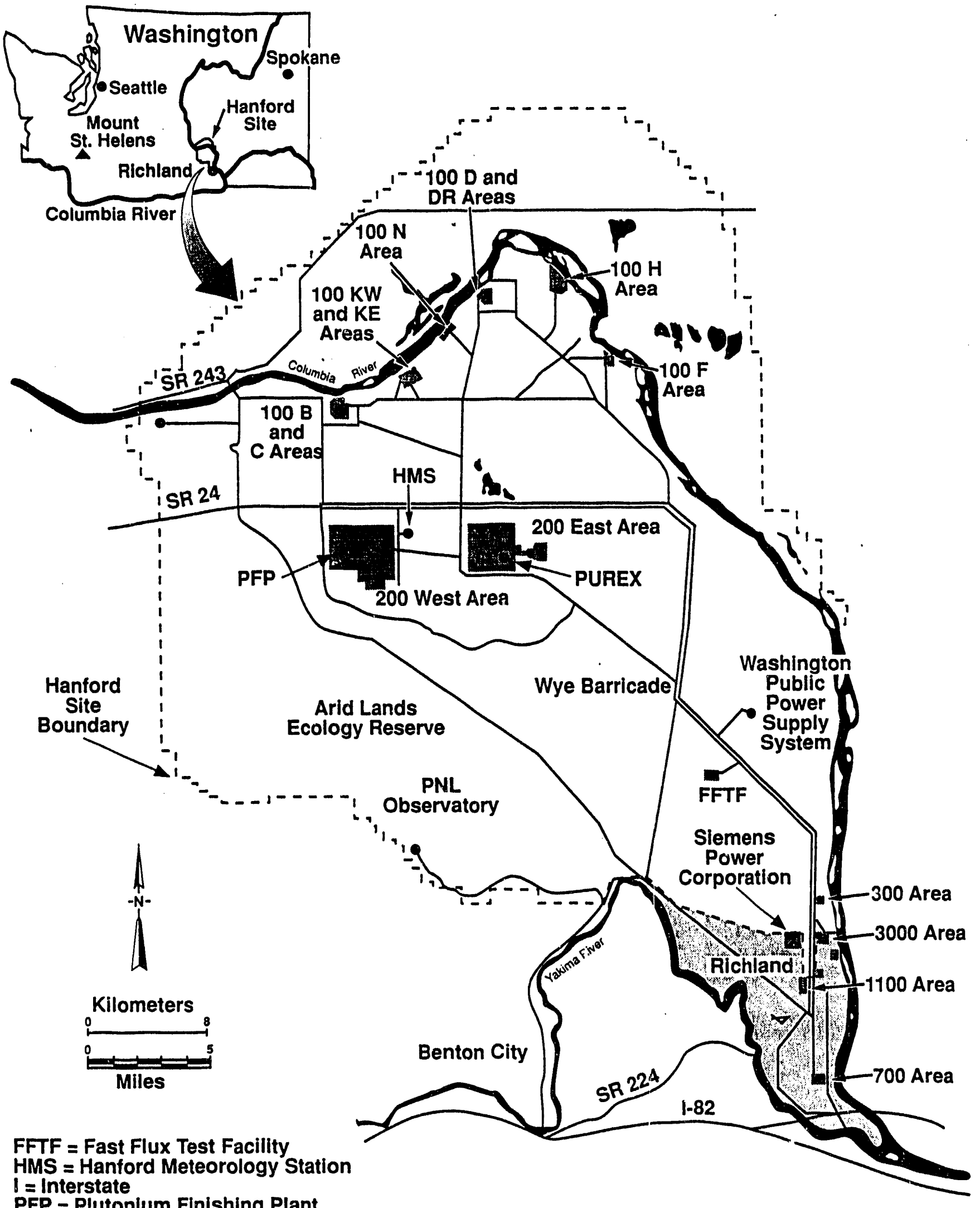

PFP = Plutonlum Finishing Plant

PNL = Pacific Northwest Laboratory

PUREX = Plutonium-Uranium Extraction (Plant)

SR = State Route 
Figure 2-4. Layout of 231-Z Building from 1960 to Early 1970's.

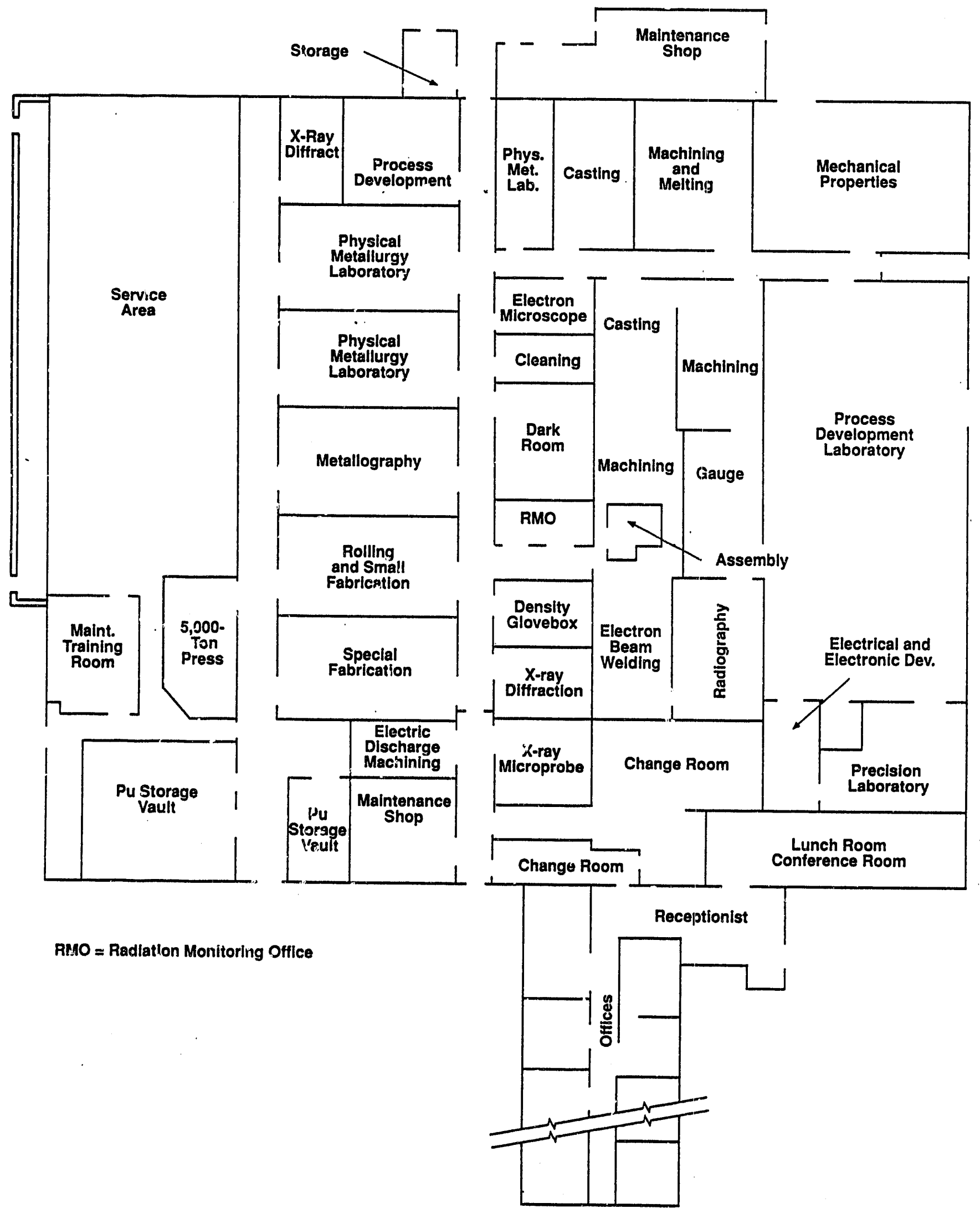


WHC-EP-0659

This page intentionally left blank. 


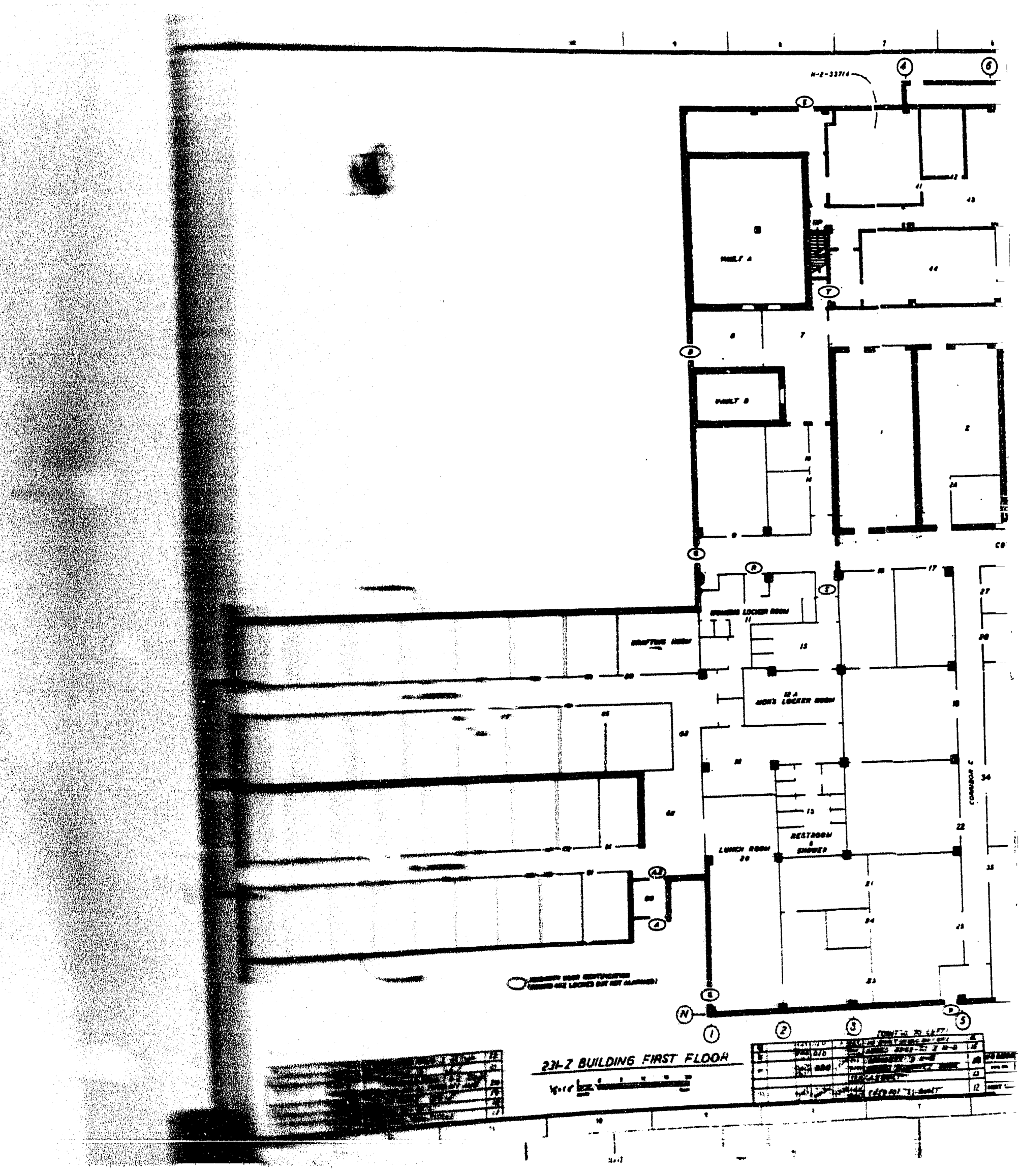


Figure 2-5. Current Layout of the 231-Z Building First Floor.

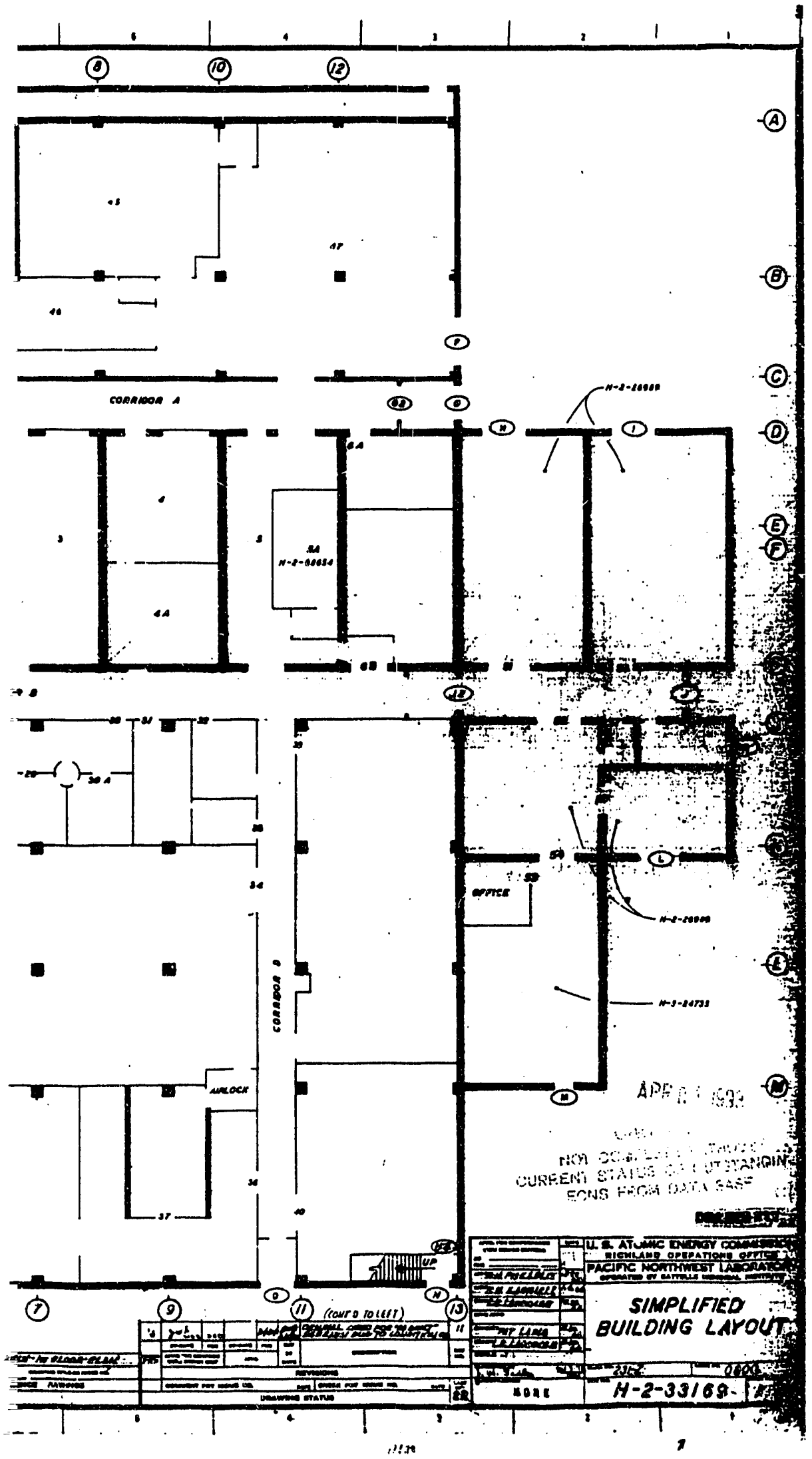


Figure 2-6. Location of Waste Items in Pacific Northwest Laboratory's Isolated Facilities - 231-Z Building.

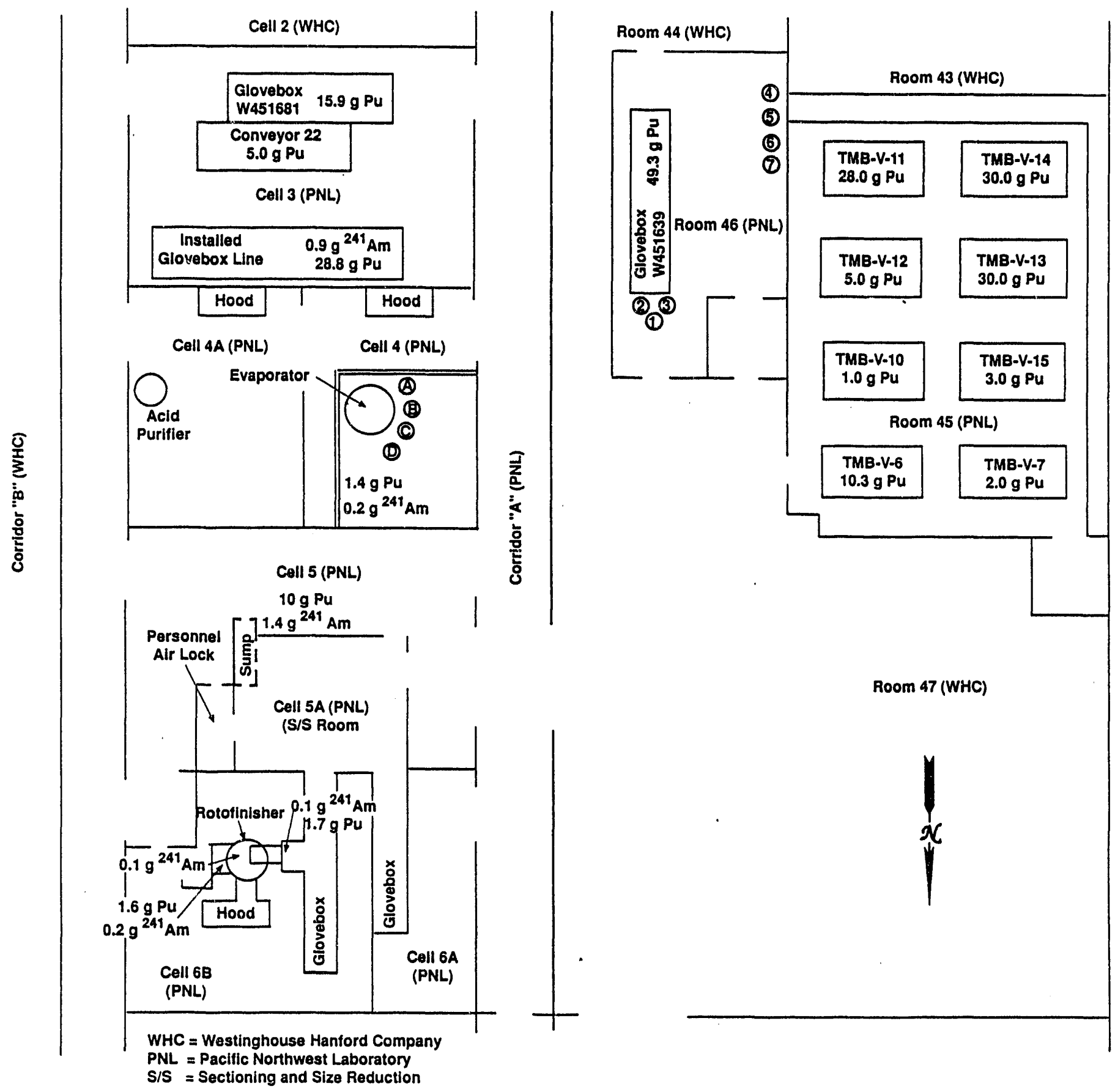


Table 2-1. Remaining TRU Waste Inventory at 231-Z.

\begin{tabular}{|c|c|c|c|}
\hline \multirow{2}{*}{$\begin{array}{l}\text { Container identification } \\
\text { number/description }\end{array}$} & \multirow{2}{*}{ Location } & \multicolumn{2}{|c|}{ Grams of TRU } \\
\hline & & Plutonium & ${ }^{241} \mathrm{Am}$ \\
\hline \multicolumn{4}{|c|}{ Burial boxes } \\
\hline $\begin{array}{l}\text { TMB-V-6 } \\
\text { TMB-V-7 } \\
\text { TMB-V-10 } \\
\text { TMB-V-11 } \\
\text { TMB-V-12 } \\
\text { TMB-V-13 } \\
\text { TMB-V-14 } \\
\text { TMB-V-15 }\end{array}$ & $\begin{array}{l}\text { Room } 45 \\
\text { Room 45 } \\
\text { Room } 45 \\
\text { Room } 45 \\
\text { Room 45 } \\
\text { Room } 45 \\
\text { Room } 45 \\
\text { Room 45 }\end{array}$ & $\begin{array}{r}10.3 \\
2.0 \\
1.0 \\
28.0 \\
5.0 \\
3.0 \\
30.0 \\
3.0\end{array}$ & $\begin{array}{l}-- \\
-- \\
-- \\
-- \\
-- \\
-- \\
--\end{array}$ \\
\hline \multicolumn{4}{|c|}{ 55-gallon drums } \\
\hline $\begin{array}{l}\text { PNL } 186020 \\
\text { PNL } 186035 \\
\text { PNL } 186036 \\
\text { PNL } 188019 \\
\text { PNL } 188021 \\
\text { PNL } 188022 \\
\text { PNL } 188023\end{array}$ & $\begin{array}{l}\text { Room } 46 \\
\text { Room } 46 \\
\text { Room } 46 \\
\text { Room } 46 \\
\text { Room } 46 \\
\text { Room } 46 \\
\text { Room } 46\end{array}$ & $\begin{array}{l}9.6 \\
0.2 \\
2.1 \\
0.1 \\
0.9 \\
1.2 \\
4.9\end{array}$ & $\begin{array}{l}-- \\
-- \\
-- \\
-- \\
-- \\
--\end{array}$ \\
\hline \multicolumn{4}{|c|}{ Other equipment } \\
\hline $\begin{array}{l}\text { Glovebox, W } 451639 \\
\text { Glovebox, W } 451681 \\
\text { Conveyor } 22 \\
\text { Installed glovebox line } \\
\text { Acid purifier } \\
\text { Evaporator } \\
\text { A, B, C, \& D Evaporators } \\
2 \text { Gloveboxes } \\
\text { Sump } \\
\text { Personnel air loc } \\
\text { Glovebox } \\
\text { Glovebox } \\
\text { Rotofinisher } \\
\text { Hood }\end{array}$ & $\begin{array}{l}\text { Room } 46 \\
\text { Cell } 3 \\
\text { Cell } 3 \\
\text { Cell } 3 \\
\text { Cell } 4 A \\
\text { Cell } 4 \\
\text { Cell } 4 \\
\text { Cell 5A } \\
\text { Cell } 5 \\
\text { Cell 5A } \\
\text { Cell 6A } \\
\text { Cell 6A } \\
\text { Cell 6B } \\
\text { Cell 6B }\end{array}$ & $\begin{array}{c}49.3 \\
15.9 \\
5.0 \\
28.8 \\
\cdots \\
1.4 \\
0.0 \\
0.0 \\
10.0 \\
-- \\
-- \\
0.7 \\
-- \\
1.6\end{array}$ & $\begin{array}{c}- \\
-- \\
0.9 \\
-- \\
0.2 \\
0.0 \\
0.2 \\
1.4 \\
-- \\
-- \\
0.1 \\
0.1 \\
0.2\end{array}$ \\
\hline \multicolumn{2}{|c|}{ Total inventory } & $214.0 \mathrm{~g} \mathrm{Pu}$ & $2.9 \mathrm{~g}^{24}$ \\
\hline
\end{tabular}




\subsection{WASTE GENERATION}

The wastes generated by $231-Z$ past operations can be segregated into radiological or nonradiological wastes in gaseous, liquid, and solid forms.

\subsection{RADIOLOGICAL WASTES}

The radioactive wastes generated have been classified into five categories:

1. Gaseous

2. Low-level liquid

3. High-level liquid

4. Miscellaneous solids

5. Failed equipment.

The five category classification was developed based on the waste's potential radioactivity levels, methods of handling, and disposal procedures.

\subsubsection{Gaseous Radioactive Wastes}

The gaseous discharge points of the $231-z$ Building were filtered by high efficiency, fire and moisture resistant, Type A filters. The use of these filters ensured against a contamination release to the environment in case of an accident involving a contamination release within one of the laboratory rooms. All glovebox gaseous effluents passed through secondary filters of equal quality before entering the exhaust duct. An air sample was located just before the exhaust fan. The filter from this sampler was changed and checked on a weekly basis.

\subsubsection{Liquid Radioactive Waste}

Throughout its operational history, 231-Z was never connected to tank farms. Occasionally liquid wastes were shipped by tank trucks to the 200 Area Tank Farms. The remainder of the liquid effluents were discharged to onsite ponds and cribs. The liquid effluents generated by $231-\mathrm{Z}$ can be characterized as follows:

- Liquids from process drains, which were essentially free of radioactive contamination, were discharged to the U-10 swamp (Reduction Oxidation Plant [REDOX] pond). This swamp was isolated, covered, and backfilled with gravel in the late 1970's to early 1980's.

- Very low-level or potentially contaminated liquid wastes were discharged to the Z-16 crib. All of the drain lines leaving the facility and going to the ump tank area, weir box, and Z-16 crib were excavated and buried as contaminated waste in accordance with the Detailed Plan for the Decontamination and Restoration of the 231-Z Facility (BNWL 1976). 
- Liquid wastes, containing mixed fission products, were discharged to the two 231-W-151 tanks located in a concrete pit to the east of the 231-Z Building. These were relatively small tanks that were routinely jetted to cribs.

The accommodation of the liquid effluent streams generates some solid wastes in the form of failed equipment, unplanned sludge accumulation and miscellaneous industrial maintenance wastes, which may or may not be contaminated with radioactivity.

\subsubsection{Solid Radioactive Wastes}

Solid wastes generated at $231-Z$ between 1969 and 1988 were segregated by their radioactivity levels into three categories: Nonradioactive, low-level, and TRU waste.

In 1969 , the primary mission of $231-Z$ was military support, with 80 to $85 \%$ of the work under the sponsorship of DMA, 10\% AEC Division of Research, and 5 to $10 \%$ other work. While the amount of military work composed 80 to $85 \%$ of the $231-Z$ support, the TRU contaminated waste generated by the facility was probably best represented by $90 \%$ defense or defense-related waste and $10 \%$ other. The defense-related work would

represent plutonium with a ${ }^{240} \mathrm{Pu}$ content of $6 \%$ or less. In fact, many plutonium criticality standards used today are still based on criticality measurements made with $5 \%{ }^{240} \mathrm{Pu}$ material.

With the cancellation of the weapons work in 1975, the facility was decontaminated and the gloveboxes removed. A phosphoric acid electropolishing decontamination facility was established by Pacific Northwest Laboratory in 1978. Later decontaminated work included the clean up and decontamination of at least 11 of the original 231-Z gloveboxes. Though a lot of the decontamination work was varied, most of it was defense-type equipment. Therefore, most of the contaminated waste generated by the facility was plutonium with an isotopic content of less than $6 \%{ }^{240} \mathrm{Pu}$. Solid wastes generated include section gloveboxes in boxes and metal containers, and solidified liquid waste in drums. The solidified waste included low-temperature, salt melt solids; absorbed liquid; and some drums of urea formaldehyde matrices.

\subsection{NONRADIOLOGICAL WASTES}

Cooling water used by vacuum systems, furnaces, and all 231-Z Building service equipment was drained into an underground line that emptied into the U-10 swamp (REDOX pond) located south of the 234-5Z Building. Solid nonradioactive wastes primarily consisted of ordinary trash originating outside of contaminated areas (e.g., offices, lunchrooms, and restrooms). 


\section{WHC-EP-0659}

\subsection{SOLID WASTE GENERATORS}

During the 20-year time period (1965-84) that the 231-Z Building was operated by PNL, solid waste was generated by the following sources:

- General Weapons Development Program

- Process waste from gloveboxes

- Numerous classified R\&D programs

- Advanced D\&D technologies, including sectioning, vibratory finishing, electropolishing, solution process, and small bench-scale work

- General laboratory procedures

- Foundry areas

- Housekeeping activities

- Four cleanout campaigns.

\subsubsection{Types of TRU Waste Generated}

Solid TRU waste was generated by $231-\mathrm{Z}$ processes such as metallurgical research on plutonium and its alloys, fabrication development work on plutonium components and reactor fuels containing plutonium or other alpha emitting materials, and advanced D\&D technology. These wastes include the following types of materials:

- Spent and failed equipment and tools

- Housekeeping items such as metal cans, glass, paper, aerosol cans, rags, plastic bottles, wipes, and cardboard containers

- Glovebox maintenance materials such as high efficiency particulate air (HEPA) prefilters, glovebox gloves, cut out plastic bags, and other miscellaneous items

- Ventilation HEPA filters and associated ductwork

- Metal fines, turnings, and oxides that adhered to other glovebox waste

- Demolition and major equipment removal, such as gloveboxes, tanks, and piping

- Absorbed liquids, acids, bases, and process chemicals

- Processing items such as polypropylene wound filters and drum filter cloth 
WHC-EP-0659

- Glovebox sections, associated ducts, tanks, refrigeration equipment, and reservoirs

- Absorbed contaminated lubricants, such as oils, and hydraulic fluids.

\subsubsection{Types of Low-Level Waste}

Until 1978 virtually all waste generated at 231-Z was disposed of as TRU waste. In approximately 1979, 231-Z implemented a nondestructive assay (NDA) system. However, relatively small amounts of waste were determined to be non-TRU as a result of the $10 \mathrm{nCi} / \mathrm{g}$ limit and conservative labeling practices. When the TRU limit changed to $100 \mathrm{nCi} / \mathrm{g}$ in 1982, the percentage of non-TRU waste increased to over $98 \%$.

The majority of non-TRU waste was generated by room activities rather than by glovebox activities as in the case of TRU waste generation. Maintenance equipment with low levels of radioactive contamination were often able to be disposed of as non-TRU. When possible, the equipment was sent to other site operations for re-use, rather than for disposal as non-TRU waste.

\subsubsection{Waste Generated by Cleanout Campaigns}

Four distinct cleanout campaigns were conducted at the 231-Z Building beginning in $1975,1982,1985$, and 1986, respectively. Each of these campaigns generated large quantities of waste, both non-TRU and TRU, to be sent to the burial grounds for storage. However, some of the waste remains in the 231-Z Building awaiting disposal (see Section 2.5).

There were 79 glovebox sections, representing a volume of $339.8 \mathrm{~m}^{3}\left(12,000 \mathrm{ft}^{3}\right)$, removed for burial as a result of the 1975 cleanout. While these gloveboxes were packaged for disposal, they were not transported to the burial grounds until 1980 . Contaninated equipment such as vacuum pumps, hydraulic systems, and refrigeration equipment that were external to, but attached to the gloveboxes, were buried with the gloveboxes when practical. A variety of uncontaminated laboratory and ventilation equipment and instrumentation, which became obsolete as the restoration of the building progressed, were either excessed following standard property disposal procedures or sent to the 200 Area LLW burial grounds.

During the fiscal year 1986 cleanout campaign, a large amount of non-TRU waste was sent to the 200 Area LLW burial grounds. The waste is summarized as follows:

- Six truckloads of plastic wrapped waste, $\sim 62.3 \mathrm{~m}^{3}\left(\sim 2,200 \mathrm{ft}^{3}\right)$

- Five plywood boxes containing waste, $-18.12 \mathrm{~m}^{3}\left(-640 \mathrm{ft}^{3}\right)$

- Cardboard cartons containing waste, $-1.42 \mathrm{~m}^{3}\left(-50 \mathrm{ft}^{3}\right)$.

The disposal of disconnected gloveboxes was the most difficult task of the cleanout because of their classification as TRU waste. Eight gloveboxes were sectioned and loaded into eight TMB-V. TRU burial containers. Electropolishing tanks, associated ventilation 
ducting, the false floor, the greenhouse, and power supplies also were removed from the building for disposal. Figures 3-1 and 3-2 show the location of the major cleanout items on the first and second floors of the 231-Z Building, respectively. 
Figure 3-1. Location of Major Cleanout Items Fiscal Year 1986 Campaign First Floor of the 231-Z Building.

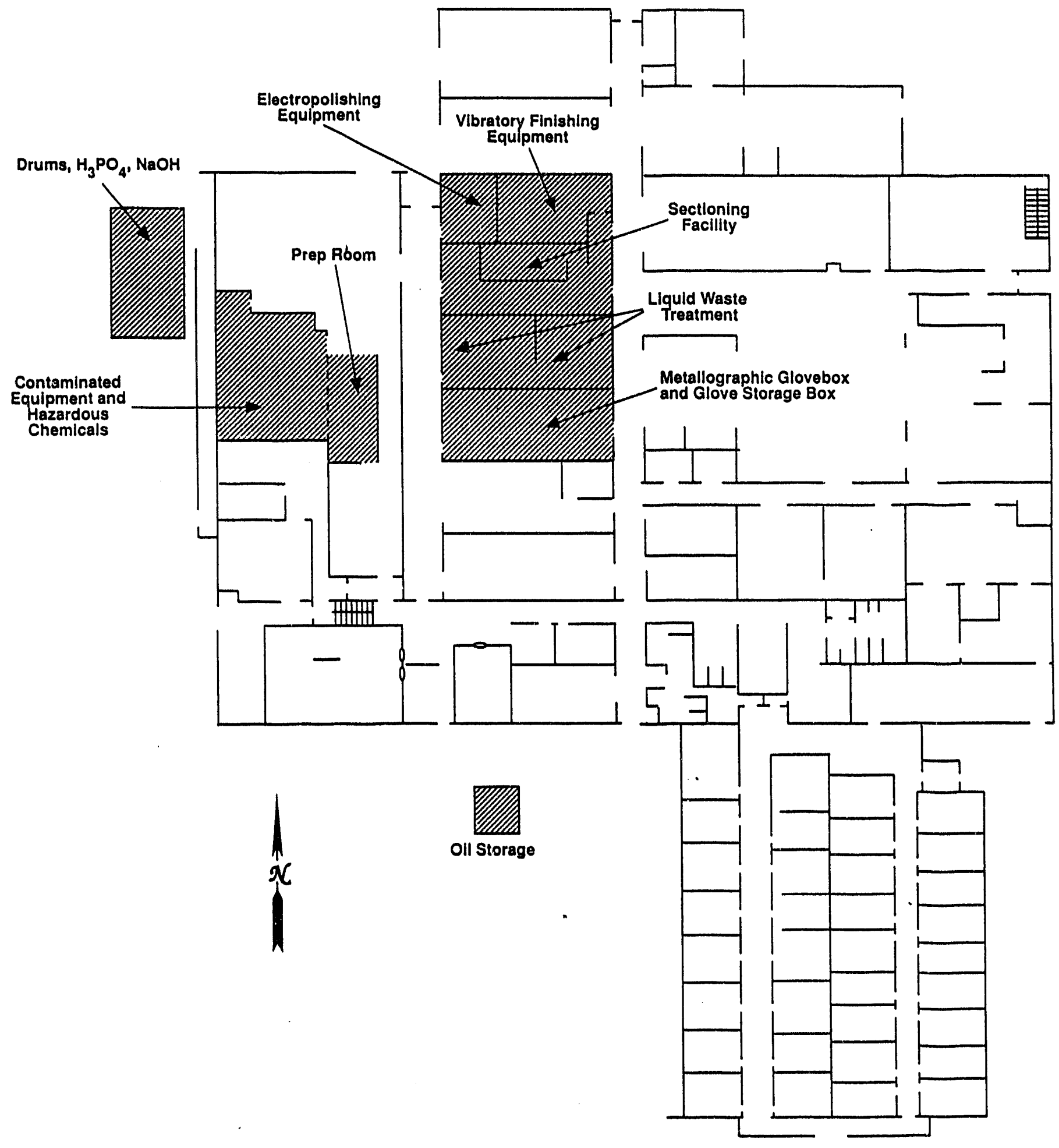

39305122.5 
Figure 3-2. Location of Major Cleanout Items Second Floor of the 231-Z Building.

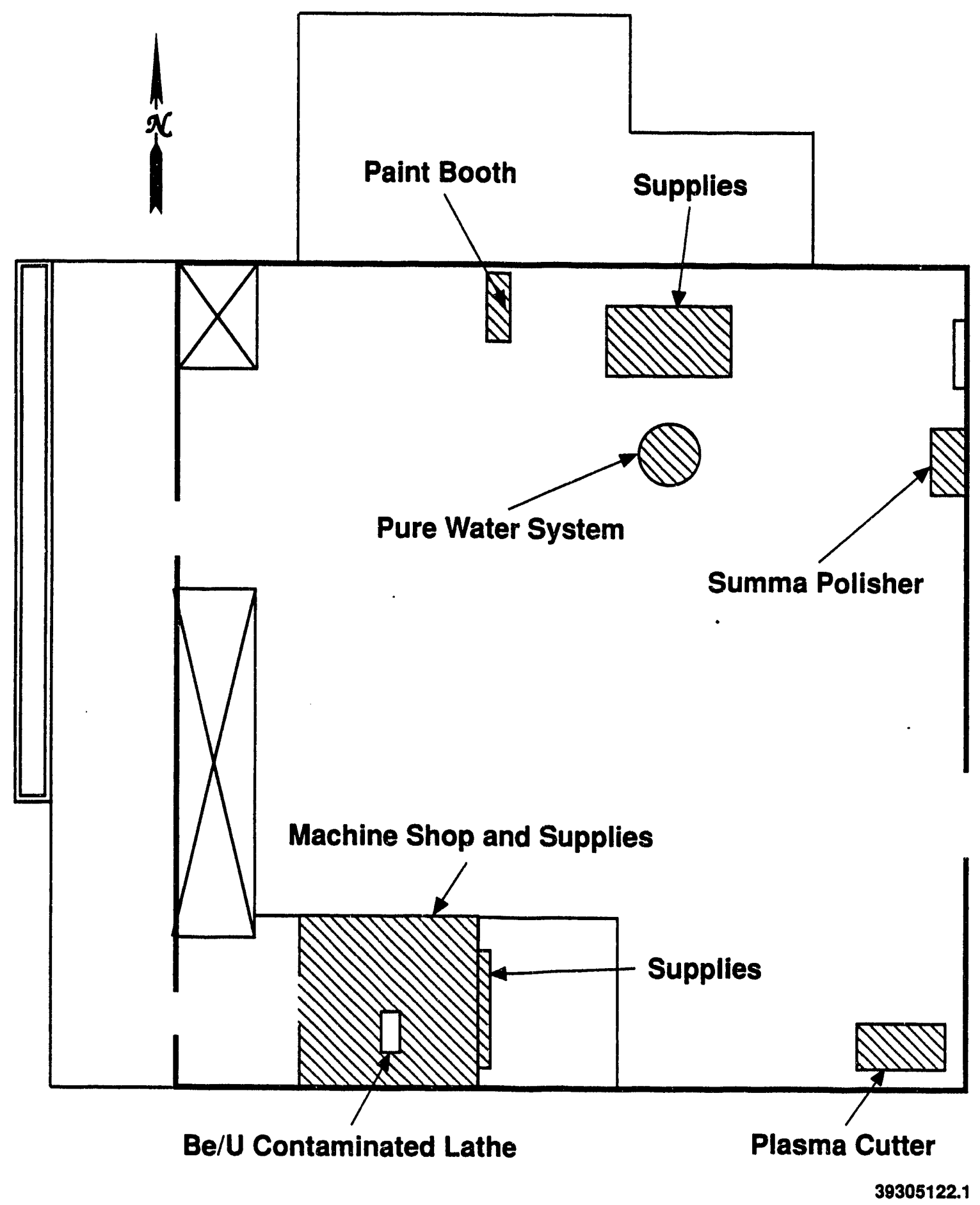


WHC-EP-0659

This page intentionally left blank. 


\subsection{SCLIO WASTE HANDLING PRACTICES AND PROCEDURES}

\subsection{HISTORICAL SOLID WASTE CHARACTERIZATION}

Solid radioactiv 3 waste handling, packaging, and characterization at the 231-Z Facility progressed through five general phases:
1. 1944-69
2. $1970-73$
3. $1974-78$
4. $1979-81$
5. $1982-88$.

During the first period, 1944-69, radioactive solid waste received very little attention as to characterization, packaging, sorting, or treating. Marginal records were maintained, with eiriphasis on the special nuclear material (SNM) operating laws. Since waste retrieval was not a factor for consideration, the radioactive waste burial conitiners were not chosen for their resistance to long-term corrosion, weathering, or degradation. The solid radioactive waste burial during this time period is not very definable with respect to today's intricate waste classification system.

The AEC directive establishing the basis for TRU waste, and the requirement for 20-year retrievable storage, was issued in 1970. From 1970 to 1973 , the $231-Z$ Facility waste practice was to consider all waste to be TRU unless it could be determined otherwise. SWBRs were kept for all containers, although the intormation on physical contents and hazardous constituents was limited.

During the next period, 1974-78, the AEC TRU limit of $10 \mathrm{nCi} / \mathrm{g}$ was in effect, however, $231-Z$ did not have the assay capability to iripligment it. To be as conservative as possible, all solid radioactive wastes from $231-Z$ were considered to be TRU. Record keeping and waste packaging improved during this time period.

Before 1979, 231-Z waste was sometimes sent to the 234-5Z Building; one reason for this may have been NDA. Because of chain-of-custody policies, it is possible that some of this 231-Z waste may have been shipped to the burial grounds as 234-5Z waste.

In approximately 1979 , the ability to assay waste packages accurately was implemented in the form of a Segmented Gamma Scan Assay System (SGSAS). With the $10 \mathrm{nCi} / \mathrm{g}$ TRU limit in effect through 1981, virtually all of the waste from 231-Z was characterized as TRU. At this time, entries on SWBRs began to be made on a per container basis, instead of a per shipment basis, improving the ability to characterize and categorize these wastes for retrieval.

In the last phase of $231-\mathrm{Z}$ waste generation, 1982-88, the $100 \mathrm{nCi} / \mathrm{g}$ TRU limit was in effect. With this change in the TRU requirements, and with improved recording, packaging, and sorting practices, virtually all the waste was able to be categorized as lowlevel. Waste acceptance criteria were developed and improved at this time also. 
RCRA requirements and other more strict compliance criteria have been applied to radioactive solid waste handling, packaging, characterization, and recordkeeping practices.

\subsection{HISTORICAL WASTE PACKAGING AND HANDLING PROCEDURES}

Eleven historical waste packaging manuals were reviewed for information regarding packaging and labeling requirements for TRU waste in retrievable storage at the Hanford Site. These manuals covered requirements from 1974 through 1988.

Packaging requirements have changed over time and have become more stringent. Table 4-1 summarizes TRU storage requirements for the Hanford Site from 1974 through 1988. The columns in Table 4-1 are not symmetrical; when a definition or requirement is consistent between manuals, text is shared under several document number columns. A blank spot indicates that no requirements or definition are found in that manual. Defiritions (i.e., hazardous and toxic materials) change from manual to manual and so require reference to each particular manual.

Some of the more significant changes that have occurred in the past 20 years with regard to the packaging, handling, and recordkeeping for radioactive wastes from $231-Z$ follow:

- The definition of TRU waste has changed since 1970, and the designation of waste packages as TRU has also changed. During the period from 1 y70 to 1973 TRU segregation was based on generator practice. From 1974 until 1982 TRU waste was segregated if the concentration of TRU was greater than $10 \mathrm{nCi} / \mathrm{g}$. In 1982 the current $100 \mathrm{nCi} / \mathrm{g}$ definition for TRU waste was implemented by the DOE.

- Because of the varied contents of the waste containers, chemical reactions can occur. Gases may accumulate, including hydrogen which can contribute to fire and/or explosicii. Since 1982 waste materials that generate $\mathrm{H}_{2}, \mathrm{O}_{2}$, or $\mathrm{NO}_{x}$ are prohibited unless drums have been permanently fitted with vent clips to allow continual release of gases or include catalyst packs to recombine any hydrogen that may be produced.

- Criticality specifications limited the amount of TRU to less than $250 \mathrm{~g}$ (8.82 oz) per 55-gal drum from $1975-78$ and to $200 \mathrm{~g} /$ drum after that time. Before 1975 the criticality limit on drums and cartons was $400 \mathrm{~g}(14.11 \mathrm{oz}$ ).

- Individual container weights were not required before 1977; however, estimated weights for pre-1977 containers were added to the records in the R-SWIMS database during the data re-entry program in the mid-1980's. Standard weights were given for each container type. All 55-gal drums, for example, were given a value of $68 \mathrm{~kg}(149.91 \mathrm{lb})$. 
- Originally, waste burial records for TRU were not done for individual containers, but for entire shipments. In 1982, TRU burial and storage records began to be based on an individual container basis. The entry of unique data for each waste container into the R-SWIMS database was not fully implemented until 1984. During the R-SWIMS re-entry program, historical TRU records were converted to an individual basis so that today there is one SWITS record for each TRU container stored at the Hanford Site.

The conversion from group data to individual container data required some assumptions $t$, be made about the containers in the group. Chief among these assumptions was that an even distribution of radiological and hazardous constituents existed among the members of the group.

LLW records are still kept for multiple containers rather than for individual containers.

- Information on the hazardous constituents of waste containers was not required before 1986. During the R-SWIMS re-entry program any available information from the SWBRs was added. However, this information is limited.

- Physical descriptions of the waste contents were not required on the SWBR before 1978. SWITS records for waste buried before 1978 list the contents as "miscellaneous" in most cases. In more recent years the physical contents description has become more detalled. Many of the records now include the weight and volume percentages of a given component in the waste container.

- Between 1972 and 1978, combustible and noncombustible waste components were segregated. Although the SWITS database did not retain a data field for this information, it was added to the physical contents description field.

- The most common TRU waste container used at the Hanford Site is the 55-gal steel drum. U.S. Department of Transportation (DOT) $17 \mathrm{C}$ or $17 \mathrm{H}$ drums with minimum wall thicknesses of $0.134 \mathrm{~cm}(0.053 \mathrm{in}$.$) and 0.109 \mathrm{~cm}(0.043 \mathrm{in}$.$) ,$ respectively, were both used. Before 1982 most of the drums were painted, so there is approximately $0.0127 \mathrm{~cm}(0.005 \mathrm{in}$.) of paint on both the exterior and interior of the drums. In 1982, galvanized drums replaced the painted drums. Recycled 55-gal drums were also permitted for the storage of TRU waste from 1973 to 1978.

- Data for wastes generated before 1970 are not included in the SWITS database.

\subsection{CURRENT WASTE HANDLING AND PACKAGING}

As discussed in Section 2.5, there is still an inventory of radioactive waste to be cleaned out of the 231-Z Facility. Any waste disposed of by 231-Z will be packaged and handled in accordance with current waste generation guidelines as contained in WHC-EP-0063, Revision 3 (Willis and Triner 1991). 
WHC-EP-0659

This page intentionally left blank. 


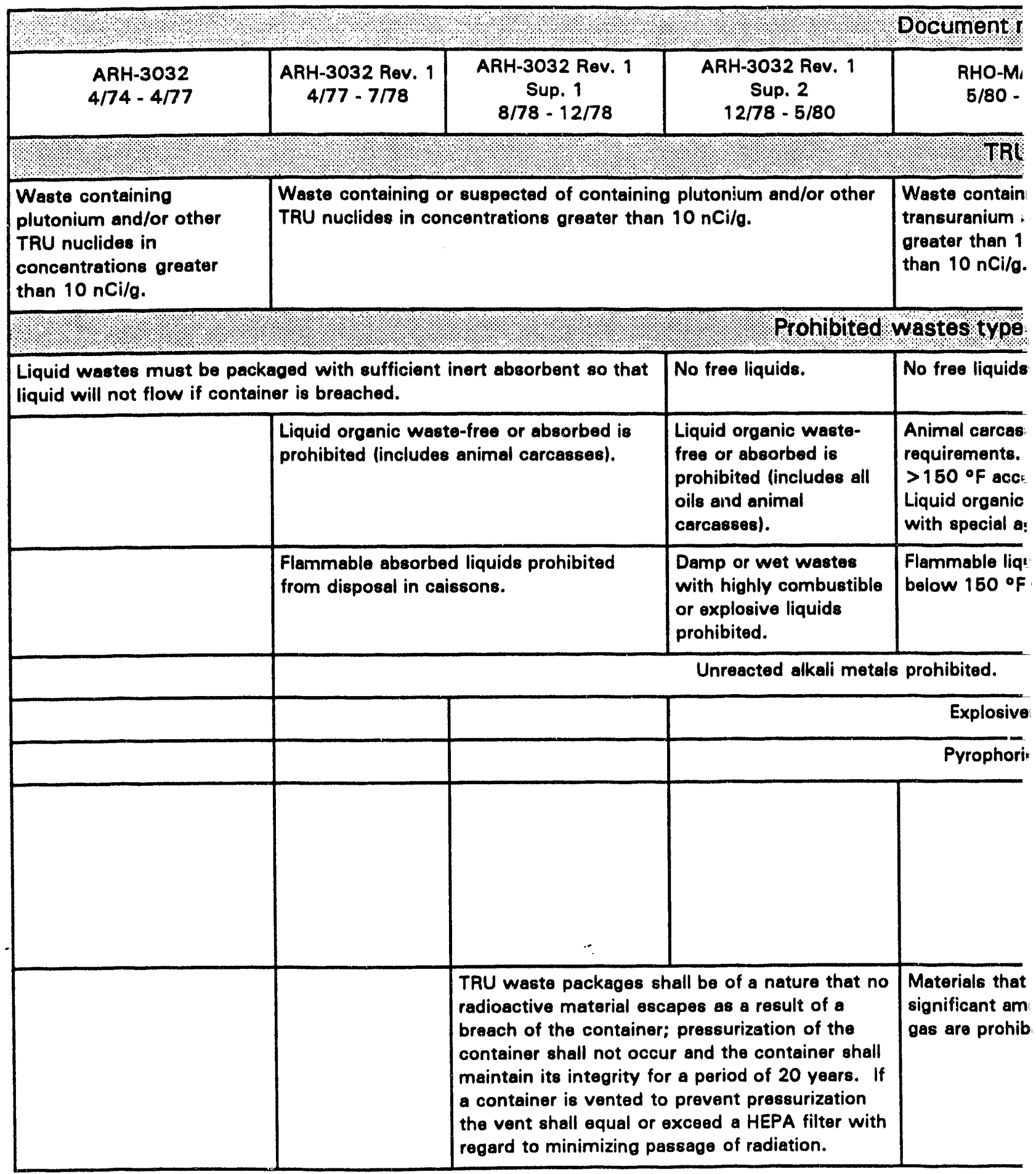




\begin{tabular}{l|c|c|c|c|}
\hline-222 & RHO-MA-222 & RHO-MA-222 Rev. 1 & RHO-MA-222 & Rev. 2* \\
$i / 82$ & $6 / 82$ Revision & $6 / 83-3 / 84$ & $7 / 84-8 / 85^{*}$ & $7 / 84-8 / 85^{*}$ \\
& $6 / 82-6 / 83$ & & & \\
\hline
\end{tabular}

\section{definition}

ig or suspected of containing

pha-emitting radionuclides with half-lives

0 years or ${ }^{233} \mathrm{U}$ in concentrations greater
Document unavailable.

Waste containing alpha-emitting radionuclides with atomic numbers greater than 92 and half-lives greater than 20 years or ${ }^{226} \mathrm{Ra}$ or ${ }^{233} \mathrm{U}$ in concentrations greater than $100 \mathrm{nCi} / \mathrm{g}$.

\section{and packaging requirements}

$$
\text { - except liquid organic wastes. }
$$

Liquid organic waste with flash point ted if properly labeled and packaged. -saste with flesh point $<150^{\circ} \mathrm{F}$ accepted proval.

ds free or absorbed with flash points spohibited.

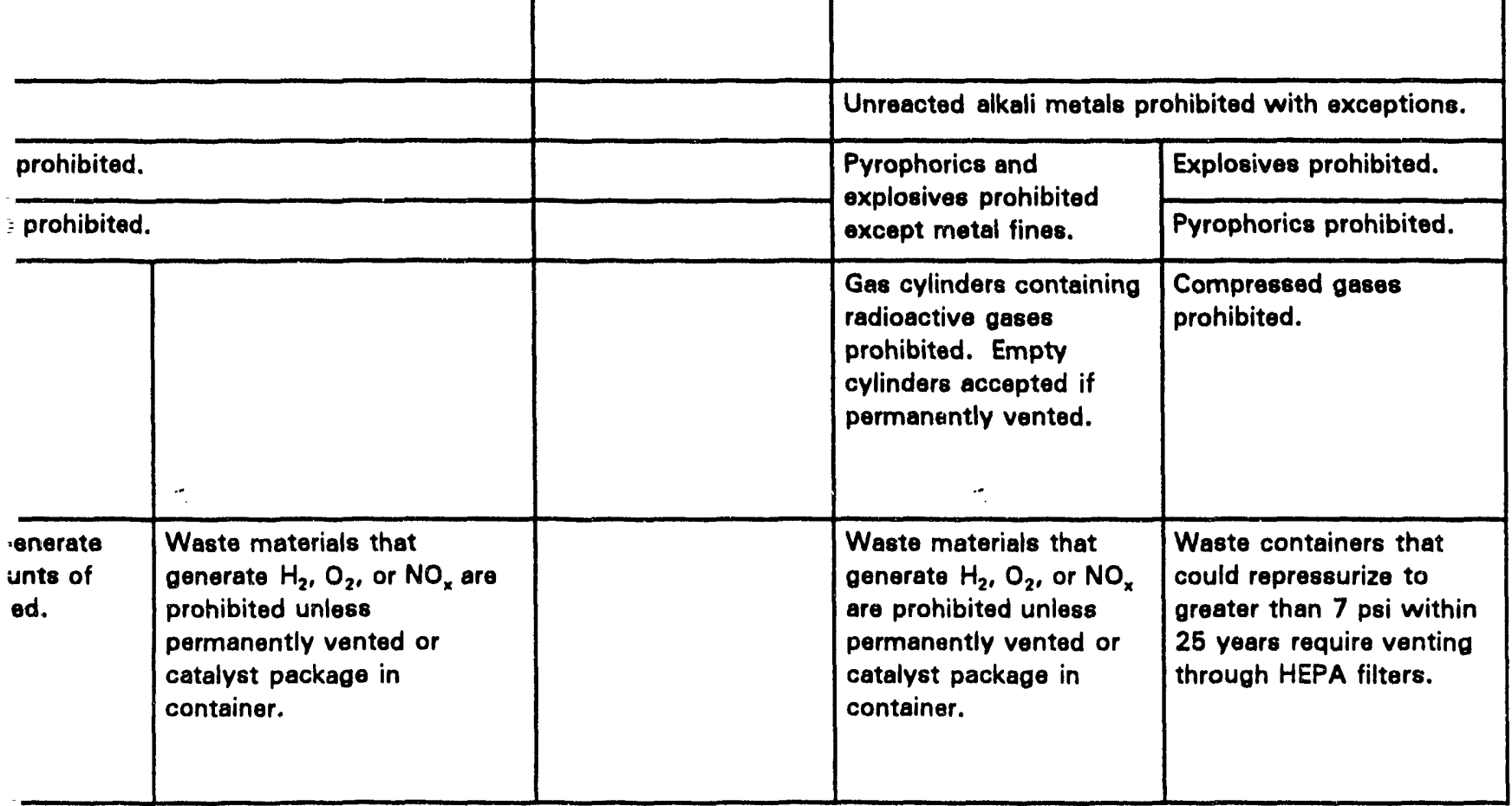




\begin{tabular}{|c|c|c|c|c|}
\hline$\$$ & ২ै২ & & & Document nut \\
\hline $\begin{array}{l}\text { ARH-3032 } \\
4 / 74-4 / 77\end{array}$ & $\begin{array}{l}\text { ARH-3032 Rev. } 1 \\
4 / 77-7 / 78\end{array}$ & $\begin{array}{c}\text { ARH-3032 Rev. } 1 \\
\text { Sup. } 1 \\
8 / 78-12 / 78\end{array}$ & $\begin{array}{c}\text { ARH-3032 Rev. } 1 \\
\text { Sup. } 2 \\
12 / 78-5 / 80\end{array}$ & $\begin{array}{r}\text { RHO-MA-2 } \\
5 / 80-6 / \%\end{array}$ \\
\hline \multicolumn{5}{|c|}{ prohibited wastes types and } \\
\hline & \multicolumn{3}{|c|}{ Hazardous and toxic materials must be treated prior to burial. } & $\begin{array}{l}\text { Hazardous and to } \\
\text { basis. }\end{array}$ \\
\hline & \multicolumn{3}{|c|}{$\begin{array}{l}\text { Exterior surfaces must be free from smearable contamination- } \\
\text { fixation allowed. }\end{array}$} & $\begin{array}{l}\text { Exterior surface } \\
\text { free from smeara } \\
\text { contamination. }\end{array}$ \\
\hline & & & & \\
\hline & \multicolumn{3}{|c|}{ Contamination that is easily airborne must be in an inner liner. } & $\begin{array}{l}\text { Loose contaminat } \\
\text { thet the surface } \\
\text { detectable loose }\end{array}$ \\
\hline \multicolumn{4}{|c|}{ Beryllium requires double containment. } & $\begin{array}{l}\text { Double containm: } \\
\text { required for all TR } \\
\text { and for all waste } \\
\text { accepted from off } \\
\text { generators. Beryl } \\
\text { mercury required } \\
\text { containment. }\end{array}$ \\
\hline
\end{tabular}


Table 4-1. TRU Storage Requirements for the Hanford Site. (4 sheets)

\begin{tabular}{|c|c|c|c|c|}
\hline$: 2$ & $\begin{array}{c}\text { RHO-MA-222 } \\
6 / 82 \text { Revision } \\
6 / 82-6 / 83\end{array}$ & $\begin{array}{c}\text { RHO-MA-222 Rev. } 1 \\
6 / 83-3 / 84\end{array}$ & $\begin{array}{l}\text { RHO-MA-222 } \\
\text { Rev. 2" } \\
7 / 84-8 / 85\end{array}$ & $\begin{array}{c}\text { RHO-MA-222 Rev. } 2 \\
7 / 84-8 / 85^{*}\end{array}$ \\
\hline \multicolumn{5}{|c|}{ ackaging requirements (cont) } \\
\hline \multicolumn{2}{|c|}{ ic materials accepted on case-by-case } & & \multicolumn{2}{|c|}{$\begin{array}{l}\text { Hazardous and toxic materials must be treated to } \\
\text { meet the waste acceptance criteria for disposal. }\end{array}$} \\
\hline $\begin{array}{l}\text { ust be } \\
\text { Iy }\end{array}$ & $\begin{array}{l}\text { Exterior surfaces free from } \\
\text { smearable contemination } \\
\text { fixation allowed. }\end{array}$ & & $\begin{array}{l}\text { Exterior surfaces free } \\
\text { from smearable } \\
\text { contamination fixation } \\
\text { allowed. }\end{array}$ & $\begin{array}{l}\text { Removable surface } \\
\text { contamination limits } \\
\text { fixation is not acceptable. }\end{array}$ \\
\hline & & & & $\begin{array}{l}\text { Flammable solids (metal } \\
\text { fines) must be mixed } \\
\text { with chemically stable } \\
\text { material to produce a } \\
\text { solidified waste matrix } \\
\text { (glass, concrete, etc.) }\end{array}$ \\
\hline \multicolumn{2}{|c|}{$\begin{array}{l}\text { In must be stabilized or contained so } \\
\text { the container remains free of } \\
\text { intamination. }\end{array}$} & & $\begin{array}{l}\text { Loose contamination } \\
\text { must be stabilized or } \\
\text { contained so that the } \\
\text { surface of the container } \\
\text { remains free of } \\
\text { detectable loose } \\
\text { contamination. }\end{array}$ & $\begin{array}{l}\text { Powders, ashes, and } \\
\text { similar particulates must } \\
\text { be immobilized in } \\
\text { concrete, glass, or similar } \\
\text { solidified matrix if } \\
>1 \text { wt\% of the matrix } \\
\text { weight is particulates } \\
<10 \text { microns in diameter } \\
\text { or if }>15 \text { wt } \% \text { is } \\
<200 \text { microns in } \\
\text { diameter. }\end{array}$ \\
\hline $\begin{array}{l}\text { It waste } \\
\text { ite } \\
\text { um and } \\
\text { ouble }\end{array}$ & $\begin{array}{l}\text { Double containment required } \\
\text { for all TRU waste. Double } \\
\text { containment is required for } \\
\text { cadmium and mercury. } \\
\text { Beryllium, cadmium, and } \\
\text { mercury must be packaged } \\
\text { with at least } 6 \text { in. of } \\
\text { concrete on all sides. }\end{array}$ & & $\begin{array}{l}\text { Double containment } \\
\text { required for all TRU } \\
\text { waste. Double } \\
\text { containment is required } \\
\text { for cadmium and } \\
\text { mercury. Beryllium, } \\
\text { cadmium, and mercury } \\
\text { must be packaged with } \\
\text { at least } 6 \text { in. of concrete } \\
\text { on all sides. }\end{array}$ & $\begin{array}{l}\text { Double containment } \\
\text { required for all TRU } \\
\text { waste. Beryllium, } \\
\text { cadmium, mercury, and } \\
\text { other class B poisons } \\
\text { must be immobilized in } \\
\text { concrete for burial. }\end{array}$ \\
\hline
\end{tabular}




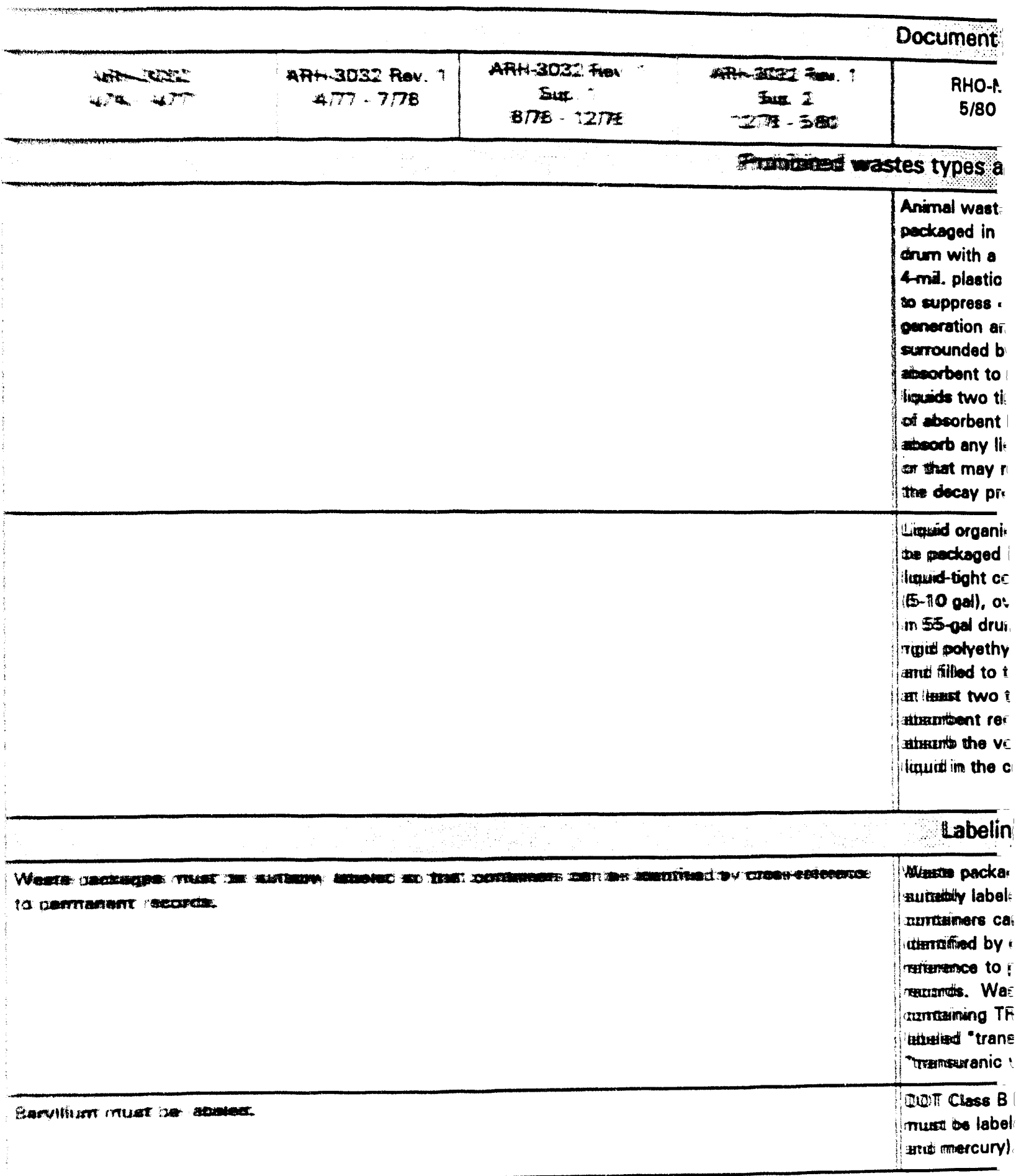


Table 4-1. TRU Storage Requirements for the Hanford Site. (4 sheets)

\section{umbers and dates}

\begin{tabular}{c|c|c|}
\hline A-222 & RHO-MA-222 & RHO-MA-222 Rev. 1 \\
$6 / 82$ & $6 / 82$ Revision & $6 / 83-3 / 84$ \\
& $6 / 82-6 / 83$ & \\
\hline
\end{tabular}

\section{id packaging requirements (cont)}

\section{must be} 55-gal inimum iner, treated 8

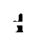
sufficient revent free ies amount equired to sid present sult from

jes8.

waste must i a sealed itainer rpackaged I with a sne liner - top with nes the sired to ume of intainers.
Animal waste must be packaged in a 55-gal drum with a minimum 4-mil. plastic liner, treated to suppress gas generation and surrounded by two times amount of absorbent required to absorb any liquid present or that my result from the decay process.
RHO-MA-222

Rev. 2*

$7 / 84-8 / 85^{\circ}$
RHO-MA-222 Rev. 2 $7 / 84$ - $8 / 85$ •
Animal waste must be packeged in a 55 -gal drum with a minimum 4-mil. plastic liner, treated to suppress gas generation, and surrounded by two times amount of absorbent required to absorb any liquid present or that may result from the decay process.

\section{requirements}

Liquid organic waste must be packaged unabsorbed in a sealed liquid-tight container (5-10 gal), overpackaged in 55-gal drum with a rigid polyethylene liner and filled to the top with at least two times the absorbent required to absorb the volume of liquid in the containers.
Liquid organic waste must be packaged unabsorbed in a sealed liquid-tight container (5-10 gal), overpackaged in 55-gal drum with a rigid polyethylene liner and filled to the top with at least two times the absorbent required to absorb the volume of liquid in the containers.
Liquid organic waste must be solidified for storage or disposal. Exceptions are considered on a case-bycase basis.

\begin{tabular}{l|l|l|l|}
\hline $\begin{array}{l}\text { must be } \\
1 \text { so that } \\
\text { be }\end{array}$ & $\begin{array}{l}\text { Waste packages must be } \\
\text { suitably labeled so that } \\
\text { containers can be identified } \\
\text { by cross-reference to } \\
\text { oss- } \\
\text { permanent } \\
\text { e packages } \\
\text { I must be } \\
\text { Iranic" or } \\
\text { aste". }\end{array}$ & & $\begin{array}{l}\text { Waste packages must be suitably labeled so that } \\
\text { containers can be identified by cross-reference to } \\
\text { permanent records. }\end{array}$ \\
\hline $\begin{array}{l}\text { oisons } \\
\text { d beryllium }\end{array}$ & $\begin{array}{l}\text { Beryllium, cadmium, and } \\
\text { mercury must be labeled. }\end{array}$ & & \\
\hline
\end{tabular}




\begin{tabular}{|c|c|c|c|c|}
\hline \multirow[b]{2}{*}{$\begin{array}{l}\text { ARH-3032 } \\
4 \sqrt{74}-4 \sqrt{77}\end{array}$} & & 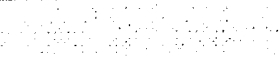 & & Document $\mathrm{n}$ \\
\hline & $\begin{array}{c}\text { ARH-3032 Rov. } 1 \\
4 \Pi 77-7 \Pi 78\end{array}$ & $\begin{array}{c}\text { ARH-3032 Rev. } 1 \\
\text { Sup. } 1 \\
8 / 78-12 / 78\end{array}$ & $\begin{array}{c}\text { ARH-3032 Rev. } 1 \\
\text { Sup. } 2 \\
12 / 78-5 / 80\end{array}$ & $\begin{array}{l}\text { RHO-MF } \\
5 / 80 \ldots\end{array}$ \\
\hline & & & & Labelingrer \\
\hline & \multicolumn{3}{|c|}{ Hazerdous and toxic waste must be labeled. } & \\
\hline & & & & $\begin{array}{l}\text { Liquid organice } \\
\text { labeled. }\end{array}$ \\
\hline & & & & Animal waste. \\
\hline & & & & $\begin{array}{l}\text { "Fissile Materi } \\
\text { and Type "E" } \\
\text { indicating seal } \\
\text { contents inclu. } \\
\text { more grams. } \\
\text { containing plut } \\
\text { must have plut } \\
\text { quantity in gre } \\
\text { on the side ank }\end{array}$ \\
\hline
\end{tabular}

NOTE: For the period 1970 through April 1974, document numbers are unknown.

- Includes RHO-MA-222, Rev. 3, 3A, and 4 (RHO 1980). The changes made in these revisione are general requirements listed under rovision 2 of RHO MA-222 (RHO 1980) are effective up to the effective date of WHC-EP DOT = U.S. Department of Traneportation.

HEPA = High-officiency particulate air (filter).

TRU = Transuranic. 
Table 4-1. TRU Storage Requirements for the Hanford Site. (4 sheets)

\section{mbers and dates}

\begin{tabular}{|c|c|c|c|c|}
\hline $\begin{array}{l}222 \\
182\end{array}$ & $\begin{array}{l}\text { RHO-MA-222 } \\
6 / 82 \text { Revision } \\
6 / 82-6 / 83\end{array}$ & $\begin{array}{l}\text { RHO-MA-222 Rev. } 1 \\
6 / 83-3 / 84\end{array}$ & $\begin{array}{l}\text { RHO-MA-222 } \\
\text { Rev. } 2^{\circ} \\
7 / 84-8 / 85\end{array}$ & $\begin{array}{l}\text { RHO-MA-222 Rev. } 2 \\
7 / 84-8 / 85\end{array}$ \\
\hline \multicolumn{5}{|c|}{ frements (cont) } \\
\hline & $\begin{array}{l}\text { DOT labels required for all } \\
\text { classes of wasto that apply } \\
\text { to the package. }\end{array}$ & & \multicolumn{2}{|c|}{$\begin{array}{l}\text { DOT labels and color coding required on all waste } \\
\text { packages. }\end{array}$} \\
\hline must be & $\begin{array}{l}\text { Liquid organics must be } \\
\text { labeled and must have flash } \\
\text { point range listed on label. }\end{array}$ & & $\begin{array}{l}\text { Liquid organice must be } \\
\text { labeled and must have } \\
\text { flash point range listed } \\
\text { on label. }\end{array}$ & \\
\hline \multicolumn{2}{|c|}{ lust be labeled. } & & \multicolumn{2}{|c|}{ Animal waste must be labeled. } \\
\hline $\begin{array}{l}\text { label } \\
\text { mper } \\
\text { equired if } \\
1 \text { or } \\
\text { rums } \\
\text { inium } \\
\text { inium } \\
\text { is posted } \\
\text { lid. }\end{array}$ & $\begin{array}{l}\text { Fiseile material label required } \\
\text { if contents include } 1 \text { or more } \\
\text { orams. Plutonium quantity } \\
\text { must be labeled if } 1 \text { or more } \\
\text { grams of plutonium is in the } \\
\text { container. }\end{array}$ & & \multicolumn{2}{|c|}{$\begin{array}{l}\text { Fissile material label required if contents include } 1 \text { or } \\
\text { more grems. Plutonium quantity must be labeled if } \\
1 \text { or more grams of plutonium is in the container. }\end{array}$} \\
\hline
\end{tabular}

nd do not affect the packeging, storage, or disposal requirements of TRU unstable or reactive wastes specifically. The 2063, Rev. O (Willis and Triner 1991 ). 


\subsection{CHARACTERIZATION OF RETRIEVABLY STORED SOLID WASTE GENERATED BY 231-Z}

The information found in this section is based primarily on data from the SWITS database. This database, which incorporated the older R-SWIMS database, is used to track information on radioactive and other wastes stored or disposed of at the Hanford Site. TRU solid waste packages have been tracked since 1970; however, there was an effort made to identify TRU wastes that were disposed of in the years immediately preceding 1970. This is the reason that the graphs and tables in this section begin with 1969. In the intervening years, changes in the requirements and regulations governing radioactive wastes have left their mark in the quantity and quality of the data contained in this database. Caveats are included in the text to alert the reader to changes that may affect the interpretation of the data provided.

The bulk of the data provided is limited to information about the TRU waste that was generated at 231-Z; however, some general information on the non-TRU waste is included for completeness. The term non-TRU waste is used instead of LLW because a small percentage of the unsegregated waste is designated only as not TRU. Tables 5-1 and 5-2 present TRU and non-TRU waste generation summaries by container type and year. Since the initial retrieval efforts and WRAP 1 will focus on 55-gal drums, these containers are considered separately from all other container types. Therefore, the term "other containers" in this report will refer to all container types except 55-gal drums. The term "drum" refers to 55-gal drums only, unless specified otherwise.

The original SWITS data that form the basis for most of the tables and figures in this section can be found in Appendix A. Each computer run is preceded by the query used to generate the data.

\subsection{SUMMARY OF 231-2 WASTE GENERATION}

\subsubsection{Waste Stored in 55-Gallon Steel Drums}

The most common waste container for TRU waste stored at the Hanford Site is the 55-gal steel drum. The drums used are either DOT $17 \mathrm{C}$ or $17 \mathrm{H}$ drums made from carbon sheet steel with minimum thicknesses of $0.134 \mathrm{~cm}(0.053 \mathrm{in}$.$) and 0.109 \mathrm{~cm}(0.043 \mathrm{in}$.$) ,$ respectively. Before 1982 most of the drums were painted, so these drums have approximately $0.013 \mathrm{~cm}(0.005 \mathrm{in}$.) of paint on both the exterior and interior of the drums. In 1982 galvanized drums replaced painted drums. Recycled 55-gal drums, were also permitted for the storage of TRU waste between 1973 and 1978.

The AEC 1970 stipulated that TRU wastes be packaged and stored as contamination-free packages for at least 20 years. The 20 -year interim period was to allow time to study permanent disposal options for TRU contaminated wastes. 
As more of the 55-gal drums reach and exceed the 20-year storage mark, more attention is being given to ascertaining the condition of these drums. A discussion of the previous studies of steel drum corrosion and degradation can be found in WHC-EP-0225, Rev. 1 (Anderson et al. 1991 ) and WHC-SA-1450-FP (Duncan et al. 1992).

Table 5-3 contains waste summary data for 55-gal drums of radioactive waste generated at 231-Z between 1969 and 1988. The upper portion of this table presents the number, total weight, and total volume of TRU waste drums. The number of TRU MW drums are also indicated. The same information for non-TRU waste follows. At the bottom of the table are the relative percentages of TRU and non-TRU wastes by container number, weight, and volume. Figures 5-1 through 5-6 present this information graphically.

5.1.1.1 Number of Drums. Between 1969 and 1988 1,978 55-gal drums of radioactive waste were generated at 231-Z. This total includes 618 drums of non-TRU and 1,360 drums of TRU waste. The total number of radioactive MW drums is 73, which includes 55 non-TRU MW drums and 18 TRU MW drums. Figure 5-1 provides a graph of the number of 55-gal drums of TRU and LLW generated at $231-Z$ by year. The major features of this graph are directly related to historical events that took place at $231-Z$.

The large amounts of waste generated from 1973 through 1975 are likely due to the remodeling of the Process Development Laboratory. Also contributing to waste generation in 1975 was the phase-out of the weapons/device fabrication operation and the attendant glovebox cleanout.

From 1976 to 1977 a major effort to refurbish the 231-Z Building and clean and tear out gloveboxes was undertaken. This cleanout generated substantial amounts of waste, particularly in 1977. Since this was largely a maintenance activity, the waste was able to be disposed of in 55-gal drums.

The Advanced Decontamination and Decommissioning Technology Program was conducted from 1978 through at least 1982. This program accounts for a portion of the drum waste generated during these years. The $231-z$ facility also went through the second, third, and fourth cleanout campaigns in 1982, 1985, and 1986, respectively. In addition, waste stored in $231-\mathrm{Z}$ vaults was packaged for disposal in this period, further contributing to the quantities of waste generated for onsite storage.

A secondary trend shown in Figure $5-1$ is the change in the ratio of TRU to non-TRU waste drums in 1979. This is depicted more clearly in Figure 5-2, which shows the relative percentages of TRU and non-TRU waste drums by year. The reason for this change was the ability to assay waste before shipment. All waste from $231-Z$ was considered at packaging to be TRU waste unless it could be demonstrated to be non-TRU. In 1979 a SGSAS became operational for the assay of $231-Z$ waste. With this new capability, all waste was no longer disposed of as TRU.

5.1.1.2 Weight. In the period between 1969 and 1988 approximately $93,857 \mathrm{~kg}$ $(206,915.78 \mathrm{lb})$ of TRU waste and $91,814 \mathrm{~kg}(202,411.81 \mathrm{lb})$ of non-TRU waste generated at 231-Z were stored in 55-gal drums. These numbers are estimates since container weights were not required for individual containers before 1977. During the R-SWIMS data re-entry program in the mid-1980's, all pre-1977 containers were assigned 
standard weights. All 55-gal drums, for instance, were assigned a value of $68 \mathrm{~kg}$ (150 lb). Since 1979, however, the average weight of $1231-\mathrm{Z}$ drums has been $72 \mathrm{~kg}(158.7 \mathrm{lb})$. However, while the average weight of TRU drums from that period was $69 \mathrm{~kg}(152.1 \mathrm{lb})$, the average weight of non-TRU drums was $149 \mathrm{~kg}(328.48 \mathrm{lb})$, making these drums more than twice as heavily loaded as the TRU drums.

The probable explanation for the average weight difference is the Decontamination Program, which began in 1978. Since there was no other contaminated research or development work underway at this time, there was no LLW pool, or any provisions for storing low-level contaminated equipment onsite external to the gloveboxes. Because of this, any conter.inated equipment that was changed out of the low-level gloveboxes, for whatevar reason, was packaged for disposal as LLW. These process pieces would typically be fairiy heavy, and their load-out would contribute to a heavily weighted drum.

Figure 5-3 presents the total weight of ooth TRU and non-TRU radioactive wastes stored annually in 55-gal drums. The relative weight percentages for TRU and non-TRU drums generated annually at 231-Z are shown in Figure 5-4. These figures show, once again, the reduction in the amount of waste designated as TRU after waste assay began.

5.1.1.3 Volume. The total volume of waste generated at 231-Z and stored in 55-gal drums is $417 \mathrm{~m}^{3}\left(14,726.14 \mathrm{ft}^{3}\right)$, of which $286 \mathrm{~m}^{3}\left(10,099.94 \mathrm{ft}^{3}\right)$ is TRU and $131 \mathrm{~m}^{3}$ $\left(4,626.2 \mathrm{ft}^{3}\right)$ is non-TRU. Annual waste generation information is shown in Figure 5-5; the volume percentages of radioactive waste stored in 55-gal drums are provided in Figure 5-6. Since all 55-gal drums have a volume of $0.21 \mathrm{~m}^{3}\left(7.42 \mathrm{ft}^{3}\right)$, the patterns shown in Figu'es 5-5 and 5-6 are the same as those described for Figures 5-1 and 5-2 (drum number), respectively. They are included here so that comparisons with later figures can be made.

\subsubsection{Waste Stored in Containers Other Than 55-Gallon Steel Drums}

Radioactive solid wastes have been stored or disposed of in a wide variety of containers other than 55-gal steel drums. Other container types used for solid waste generated at $239 \cdot \mathrm{Z}$ include the following:

- Burlap, cloch, paper, or plastic bags

- Concrete boxes

- Fiberboard/plastic boxes, cartons, or cases

- Metal drums, barrels, or kegs (other than 55-gal drums)

- Metal boxes, cartons, and cases

- iRP boxes

- Wooden boxes, cartons, and cases.

Some items were disposed of or stored without additional packaging, such as dump trucks; gloveboxes; HEPA filters; miscellaneous scrap; trucks, flatbeds, compactors, loadluggers; and self-con.ained equipment. These items are also included in the "other container" category. 
Table 5-4 summarizes the waste data for containers of radioactive waste, other than 55-gal drums, that were generated at $231-Z$ between 1969 and 1988 . The upper portion of this table indicates the number, total weight and total volume of TRU waste stored in other containers. The number of other containers of TRU MW is also provided. The same information for non-TRU waste follows. At the bottom of this table are the relative percentages of TRU and non-TRU wastes by container number, weight, and volume. Figures 5-7 through 5-12 present these data graphically.

5.1.2.1 Number of Other Containers. Between 1969 and 13881,993 other containers of radioactive waste were generated at $231-Z$. Of these containers, 861 hold TRU waste, while 1,132 contain non-TRU waste. For reference, during the same period of time a total of 1,978 55-gal drums of radioactive solid waste were generated at 231-Z. Figure 5-7 is a graph of the number of other containers of TRU and non-TRU waste generated at 231-Z by year. The largest number of other containers containing TRU waste (715) was generated in 1969. This is the result of an inordinately large number of fiberboard/plastic boxes, cartons, and cases. It is possible that this is related to the cleanup effort that was required as $231-Z$ prepared to assume device fabrication work from Rocky Flats following the fire there in 1969. Other than 1969 and 1970, the vast majority of other containers contain non.TRU waste. In the years 1979 to 1988 over $95 \%$ of the waste is non-TRU, with fiberboard/plastic boxes, cartons, and cases accounting for over $80 \%$ of the non-TRU total.

Figure 5-8 presents the relative percentages of TRU and non-TRU containers other than 55-gal drums. Two things are apparent from this figure: no waste was packaged in other containers from 1974 to 1976, and after 1977 almost all of the waste in other containers was non-TRU. The AEC directive establishing a basis for distinction between TRU and non-TRU waste was announced in 1973. In the absence of positive evidence to the contrary, all waste was considered to be TRU at 231-Z. For this reason, there was no waste characterized as non-TRU during the mid-1970's. Since it was also the practice to store retrievable TRU waste in 55-gal drums, there were no other containers generated during this period. Once the definition of TRU changed again in 1978, and $231-Z$ considered some waste to be non-TRU, virtually all of the 231-Z waste packaged in other containers became non-TRU.

5.1.2.2 Weight. In the period between 1969 and 1988 approximately $526,053 \mathrm{~kg}$ $(1,159,728.8 \mathrm{lb})$ of radioactive solid waste was generated at $231-\mathrm{Z}$ and placed in containers other than 55-gal drums. This total includes approximately $231,386 \mathrm{~kg}$ $(510,110.22 \mathrm{lb})$ of TRU and $294,667 \mathrm{~kg}(649,618.5 \mathrm{lb})$ of non-TRU contaminated material. These weights are approximations because individual container weights were not required to be recorded for individual containers before 1977. During an update of the R-SWIMS database in the mid-1980's, all waste containers without recorded weights were assigned standard values. For example, all $2-\mathrm{ft}^{3}$ boxes were given a standard weight of $5.5 \mathrm{~kg} \mathrm{(12} \mathrm{lb)} \mathrm{and} \mathrm{5-gal} \mathrm{lard} \mathrm{cans} \mathrm{were} \mathrm{assigned} \mathrm{a} \mathrm{standard} \mathrm{weight} \mathrm{of} 22.7 \mathrm{~kg}(50 \mathrm{lb})$.

Figure 5-9 depicts the weight of TRU and non-TRU waste stored in containers other than 55-gal drums on an annual basis. The most notable feature of this graph is the TRU waste peak in 1980, with a secondary peak in 1981. The large weight of waste disposed of in these 2 years is due to the shipment of 19 extremely large FRPs to burial. These boxes contain approximately 56 gloveboxes and 9 pieces of other equipment that were 
removed from 231-Z during the clesnout effort in 1976 and 1977. After waiting in internal storage for several years, these FRPs were loaded out and shipped to Burial Ground 218-W-4C in the 200 West Area. Table 5-5 contains a listing of the burial boxes removed during this campaign, their weight and volume, and the amount of TRU in each.

Also evident in Figure 5-9 are waste generation peaks associated with the various cleanup campaigns of the 1980's. With the exception of the large FRPs containing gloveboxes (which were loaded in 1976 and 1977), all waste disposed in other containers after 1979 is non-TRU.

Figure 5-10 shows the percent contribution of TRU and non-TRU waste to the total annual weight of waste packaged in other containers. Because of the practice of storing TRU waste in drums when possible, and storing non-TRU waste in other containers, proportionately less of the other container waste is TRU.

5.1.2.3 Volume. The volume of waste generated at 231-Z and packaged in containers other than 55-gal drums during the period from 1969 through 1988 is $2,053 \mathrm{~m}^{3}$ $\left(72,500.62 \mathrm{ft}^{3}\right)$. TRU wastes account for $1,160 \mathrm{~m}^{3}\left(40,964.79 \mathrm{ft}^{3}\right)$ of the total volume; non-TRU wastes account for $893 \mathrm{~m}^{3}\left(31,535.83 \mathrm{ft}^{3}\right)$. Figure 5-11 shows annual volumes of TRU and non-TRU wastes generated by $231-Z$ and packaged in containers other than 55-gal drums, the 19 FRP containers disposed of in 1980 and 1981 , and the volume of waste generated in 1969. Figure 5-12 shows the relative contribution of TRU and non-TRU wastes to the total volume of waste in other containers for each year.

\subsubsection{Summary of Waste Generation Rates at 231-Z Between 1969 and 1988}

5.1.3.1 Number of Waste Containers. Between 1969 and 1988 there were 3,971 containers of radioactive solid waste generated at 231-Z. 55-gal drums account for $50 \%$ of the total number of containers. Containers of TRU compose $56 \%$ of the total container numbers.

Figure 5-13 shows the total numbers of both TRU and non-TRU waste containers generated on an annual basis during this period. The difference in the amount of waste characterized as TRU and non-TRU from 1969 to 1988 is most evident in this graph. Changes in the DOE (formerly AEC) regulations and 231-Z disposal practices directly affected the proportion of the waste determined to be TRU and non-TRU. A significant portion of the waste stored as TRU before 1979 may be redesignated as LLW upon characterization at WRAP.

5.1.3.2 Total Weight. Approximately $711,724 \mathrm{~kg}(1,569,056.4 \mathrm{lb})$ of radioactive solid waste was generated at $231-Z$ between 1969 and 1988. Waste packaged in 55-gal drums accounts for about $26 \%$ of the total weight of waste from $231-Z$, with $74 \%$ of the total weight composed of waste packaged in some other type of waste container. 
Waste designated as TRU makes up $46 \%$ of the total weight, while waste designated as non-TRU makes up the remainder. Figure 5-14 provides a graph of the total weight of TRU and non-TRU waste generated at $231-Z$ on a yearly basis between 1969 and 1988. This graph shows that while the numbers of containers declined in later years, the weight of waste actually increased. This is because fewer containers and containers of larger size were being used to store the waste.

5.1.3.3 Total Volume. In the period between 1969 and $19882,469 \mathrm{~m}^{3}\left(87,191.44 \mathrm{ft}^{3)}\right.$ of radioactive solid wastes were generated at $231-z$. Only $17 \%$ of this volume is composed of 55 -gal drums; the remaining $83 \%$ of the volume is made up of other container types. TRU wastes account for $59 \%$ of the waste volume, while non-TRU wastes make up the remaining $41 \%$. Figure 5-15 shows the total volume of TRU and non-TRU waste generated at $231-Z$ on a yearly basis. The very large size of the 19 glovebox FRPs disposed of in 1980 and 1981 is evident here; in fact they account for over $38 \%$ of the total TRU waste volume from $231-Z$.

\subsection{WASTE CONTAINERS}

\subsubsection{TRU Waste Containers}

Table 5-1 provides a summary of the TRU waste generated annually by $231-\mathrm{Z}$ from 1969 to 1988 sorted by container type. The greatest number of containers are 55-gal drums, $61 \%$ by count; however, there are also significant numbers of fiberboard/plastic boxes, cartons, and cases in 1969 and 1970. The majority of the weight of TRU waste is contained in FRPs, $52 \%$ by weight, with an additional $29 \%$ in 55 -gal drums. The FRPs are all from 1980 and 1981 , and contain the previously mentioned gloveboxes. The percentages for all container types and the weight and volume of these containers are shown for each year in this table.

\subsubsection{Non-TRU Waste Containers}

Table 5-2 provides a summary of the non-TRU waste generated by $231-Z$ from 1969 to 1988 by container type. Fiberboard/plastic boxes, cartons, and cases were the most common containers used, in many years accounting for more than $54 \%$ of the total non-TRU waste count. Significant numbers of metal drums, barrels, and kegs; selfcontained equipment; miscellaneous scrap; and HEPA filters were also generated. The greatest weight of non-TRU waste, $46 \%$, is composed of waste in trucks, flatbeds, compactors, loadluggers, and dump trucks, although there are also large amounts of waste stored in 55-gal drums and metal boxes, cartons, and cases. 


\subsection{TRU WASTE STORAGE LOCATIONS}

Table 5-6 provides the storage locations for TRU waste packaged in 55-gal drums by year. In general, the bulk of the drums generated in 1 year are stored primarily in one facility. Storage locations for TRU waste packaged in other containers are shown in Table 5-7. A summary of 231-Z waste by storage location follows:

- 218-W-3A - Burial Ground 218-W-3A consists of 14 earthen-bottom, gravel filled trenches, with waste emplaced from May 1970 to April 1988. Drums and other containers from $231-Z$ were disposed of here only in 1970 and 1971. None of this waste is listed as containing hazardous constituents.

- 218-W-4B - Burial Ground 218-W-4B, consisting of 14 trenches, accepted retrievable waste through September of 1978. Drum and other container waste from 231-Z was buried here from 1969 to 1978 . Drums from 231-Z containing beryllium and oil from 1972 through 1976 are recorded as being stored at this site.

- 218-W-4C - Burial Ground 218-W-4C consists of six trenches, with the first waste emplaced in March 1978. 231-Z drum waste was sent to this area from 1978 to 1983 , with other containers emplaced in 1980 and 1981 . One 55-gal drum of MW, containing sodium, was buried here in 1982. This is the only recorded MW container at this site.

\subsection{PHYSICAL CONTENTS OF TRU WASTE CONTAINERS}

The physical contents of 55-gal drums are shown in Tables 5-8 through 5-10. There is a separate table for each storage location. The top portion of each table indicates the number of drums for which a given component is listed; the bottom part of the table indicates the percentage of the total drums from $231-Z$ in that burial location that contain the listed constituent. The physical contents for TRU waste containers, other than 55-gal drums, can be found in Tables 5-11 through 5-13.

It should be noted that before 1978 physical contents were not required to be listed on the burial records. A great many of the contents on early records are listed only as "miscellaneous". Also important to realize are the limitations of the SWITS database. The database was searched for information on physical contents of TRU drums and other containers, by storage facility and year. In some cases, the number of waste containers listed for a storage facility in the search is substantially less than the number of drums or other containers known to be stored there. This is true to varying degrees for all storage sites, from 1971 through 1979. A further search was done for waste containers with no listing in the physical constituents field; this search did not revoal any further waste containers. 


\subsection{RADIOLOGICAL DESCRIPTION OF 231-Z SOLID WASTE}

Table 5-14 shows the number of grams of TRU contained in waste stored in 55-gal drums each year by storage location; Table 5-15 provides the same information for containers other than 55-gal drums. Figure 5-16 combines the information on these tables in a graph that shows the total amount of TRU present in waste packages from $231-Z$ by year. It should be noted that not all SWITS records for TRU waste containers (particularly those from the early 1970's) list the number of grams of TRU.

The four notable peaks in Figure 5-16, all above $900 \mathrm{~g}$ (31.75 oz) of TRU, are associated with previously discussed operations at $231-Z$. The peak in 1973 corresponds to process updates and the tearing out of old equipment. Weapon's program cleanout and disposal from gloveboxes resulted in the peak in 1974. In 1977 the cleaning of gloveboxes in preparation for changeout resulted in disposal of a large amount of TRU. Finally, the peak in 1980 corresponds to the disposal of FRPs containing gloveboxes.

\subsection{RADIOACTIVE ISOTOPES PRESENT IN 231-Z SOLID WASTE}

Information on radioactive isotopes was obtained from the SWITS database and from the 231-Z Safety Analysis Report (SAR) Supplement (BNWL 1970). While the information from SWITS is taken from burial records, and therefore represents isotopes known to be in the waste stream, the data from the SAR represents isotopes used in 231-Z processes and laboratories, which may or may not be in the solid waste stream. Listed below are isotopes known or suspected to be in the 231-Z solid waste stream:

- Plutonium - Isotopes ${ }^{238} \mathrm{Pu},{ }^{239} \mathrm{Pu},{ }^{240} \mathrm{Pu},{ }^{241} \mathrm{Pu}$, and ${ }^{242} \mathrm{Pu}$ are all referred to specifically in the SAR (BNWL 1970). Work with plutonium oxide was conducted, including $20 \mathrm{wt} \%{ }^{238} \mathrm{PuO}_{2}$ mixed with sugar and a small amount of water, which was then heated and poured into containers for the Critical Mass Physics Department. The Critical Mass Laboratory also used 2-in. square cubes of plutonium oxide-polystyrene in some experiments. Personnel interviews indicated that a substantial quantity of scrap from the cube fabrication process were disposed of to the burial grounds. It was reported that internal heating sometimes caused these cubes to bubble and deform. Plutonium turnings or other pyrophoric scrap were routinely burned to a safe oxide and then stored for eventual return to recovery operations.

The following plutonium isotopic breakdowns were obtained from the period 1970 to 1972 . This isotopic breakdown is considered to be representive of the later years of $231-Z$ operation as well.

- Uranium - Natural, depleted, and enriched uranium are all listed as waste forms in the SWITS database. The SAR refers to small quantities of ${ }^{233} \mathrm{U}$ and ${ }^{235} \mathrm{U}$ being handled in 231-Z. 
WHC-EP-0659

\begin{tabular}{|c|l|l|l|l|l|}
\hline & ${ }^{238} \mathrm{Pu}$ & ${ }^{230} \mathrm{Pu}$ & ${ }^{240} \mathrm{Pu}$ & ${ }^{241} \mathrm{Pu}$ & ${ }^{242} \mathrm{Pu}$ \\
\hline$(1)$ & 0.04 & 93.03 & 6.30 & 0.60 & 0.03 \\
\hline$*$ & 0.01 & 91.26 & 8.11 & 0.58 & 0.04 \\
\hline & 0.088 & 85.67 & 11.53 & 2.32 & 0.28 \\
\hline$*$ & 0.28 & 75.22 & 18.35 & 5.05 & 1.14 \\
\hline$(2)$ & 0.09 & 72.35 & 22.35 & 4.21 & 0.00 \\
\hline$*$ & 0.35 & 68.50 & 23.10 & 5.61 & 2.38 \\
\hline
\end{tabular}

(1) Normal stream

(2) Special AEC lease

- Plutonium oxide for cubes.

- Neptunium - The SAR refers to small quantities of ${ }^{237} \mathrm{~Np}$ being handled in the plant. The SWITS database also contains one reference to ${ }^{237} \mathrm{~Np}$ in the solid waste. This solid waste is in two drums from 1977 which are stored in Burial Ground 218-W-4B.

- Thorium - The SWITS database contains one entry of ${ }^{232} \mathrm{Th}$, stored in one drum from 1971 located in Burial Ground 218-W-3A.

\subsection{HAZARDOUS CONSTITUENTS OF SOLID WASTE GENERATED BY 231-Z}

This section provides a review of the data on the hazardous components known or suspected to be in the solid waste stream from $231-Z$. Information was gathered from several sources, including: 231-Z Building SAR (BNWL 1970), SWITS, Solid Waste Stream Hazardous and Dangerous Components Study (WHC 1992), SWBRs, personnel interviews, and Unstable and Reactive Chemicals in Transuranic Retrievable Waste at the Hanford Site (Reddinger 1992). The hazardous contents of the MW containers in each burial ground are shown in Tables 5-16 through 5-18.

Table 5-19 provides a list of all known or suspected hazardous constituents in the 231-Z solid waste stream. The reference source for each specific chemical is also included. Because of the inherent health and safety risks of chemicals and chemical combinations, wherever data suggested the possible existence of a hazardous material in the solid waste stream, that chemical or compound was included in the table.

Until at least 1970 the segregation of potentially incompatible hazardous wastes was based solely on the knowledge of the personnel packaging the waste. Since 231-Z was never connected to the tank farms, liquid waste would normally have been sent to cribs and ponds. Up until the early 1970's, however, free liquids were disposed of in the solid waste stream.

The final two columns in Table 5-19 contain information on the toxicity and hazards associated with each of the chemicals listed. The first of these columns lists the EPA 
toxicity category, if designated, which was determined using the EPA "Spill Table" (40 CFR 302.4). Category $X$ marks the most ioxic chemicals, followed by Categories $A$, $B, C$, and D, listed in order of decreasing toxicity. The EPA "Spill Table" (40 CFR 302.4) is incorporated by reference into the (WAC 173-303), "Dangerous Waste Regulations". The final column lists the DOT designation found in the DOT Hazardous Materials Table (49 CFR 172.101) and comments.

Tables 5-20 and 5-21 provide a summary of the information taken from the SWBRS and the SWSDRs regarding the hazardous contents of TRU and non-TRU waste containers. These data were compiled by a complete review of all $231-z$ burial records.

Listed below are the chemicals known, or suspected, to be in the $231-\mathrm{Z}$ solid waste stream. Information on use, forms, disposal practices, and retrieval hazards is included wherever possible.

- Acetone - This is commonly used in processing. Some residual liquid may have been present in discarded containers.

- Aerosol Cans - Unvented cans, including Krylon", lubricants, window cleaner, and solvent sprays are reported to be present in the solid waste.

- Alcohol - This is used to etch specimens during metallography. Some residual liquid may have been present in discarded containers.

- Asbestos - This is present in torn out floor tiles, lagging, and other insulation.

- Benzene - This is used conservatively in some glovebox operations.

- Beryllium - Metallurgical research for fuels development. A large quantity of beryllium was disposed of from 1960 to 1978, primarily in the form of beryllium chips in cardboard boxes. Site personnel noted no special packaging procedures to isolate these waste chips. It is likely that some of the waste was double-bagged and mixed with glovebox waste. Typical amounts per waste container were 200 to $300 \mathrm{~g}(7.05$ to $10.58 \mathrm{oz})$ with the most beryllium in one container estimated at $1 \mathrm{~kg}(2.2 \mathrm{lb})$.

- Cadmium - Laboratory personnel disposed of some cadmium metal in waste boxes.

- Carbon Tetrachloride - This is used as a fluid for measuring the density of plutonium specimens.

- Cellulose Acetate - Replication tape was used in structure and impurity analyses.

\footnotetext{
'Krylon is a trademark of Borden, Incorporated.
} 
- Cyanide Salts - Large quantities were used in the electroplating baths. The solution from these baths typically would have been sent to the 231-Z cribs.

- Freon-113 - This is used in ultrasonic cleaning of plutonium parts. It is also used as a fluid for measuring the density of plutonium specimens.

- Graphite - Suitably protected graphite crucibles were used to hold plutonium metal during melting for casting processes.

- Hydraulic Fluid with Polychlorinated Biphenyls (PCB) - This may be present as a contaminant in gloveboxes and other equipment that were disposed of to solid waste.

- Hydrochloric Acid - This is used to clean the replicas in structure and impurity analyses.

- Hydrogen Peroxide - Small volumes in pint bottles were stored in boxes in the laboratory.

- Lard Oil - No attempt was made to rinse or stabilize solvents. Before the ban on free liquids, solvents were bagged and went out with no kitty litter or other absorbent.

- Lead - In the form of sheets and pigs, lead was entered on burial records from 231-Z. It is certain to be present in the solid waste in significant quantities.

- Magnesium Oxide - This is used as a fire extinguishing agent in gloveboxes. Because of the serious consequences of a glovebox fire, fire extinguishing drills were conducted frequently.

- Mercury - This is used to check the void volume of casting molds. Mercury lost in spills and from broken instruments was reported to have been disposed in the solid waste from $231-2$.

- Methylene Chloride - At least 37.85 to $75.7 \mathrm{~L}$ (10 to 20 gal) of methylene chloride paint strippers were disposed of in 55-gal drums.

- Molybdenum - Personnel indicated that molybdenum may be present in the 231-Z solid waste stream.

- Nitric Acid - Large amounts were used in the cleaning and decontamination of molybdenum. In the mid-1980's nitric acid was pumped out of the vaults and transported to the 200 East Area liquid waste tanks. It is estimated that there are small amounts in solid waste burial.

- Oll - Many oils were used in the processes and experiments at 231-Z. Oils were used as lubricants, in cutting operations, etc. Most of the gloveboxes had oil or hydraulic lines or containers. 
- Phosphoric Acid - Contaminated rags were disposed of *u the waste stream without further processing. Plutonium contaminated phosphoric acid reportedly was also disposed of.

- Plutonium Nitrate - This was concentrated and shipped by the 231-Z Facility before the Plutonium Finishing Plant began operating.

- Polypropylene - Large numbers of polypropylene wound filters were used to keep the phosphoric acid baths clean. When the filters were changed out they were disposed of with plenty of kitty litter or absorbent. There is reported to be a thick, gooey sludge and syrup in the filters which will make retrieval and cleanup efforts especially difficult.

- Polystyrene - Scraps of plutonium oxide - polystyrene from the cube fabrication process were disposed of in substantial quantities. Hydrogen buildup and bubbling of the surface were reported in these cubes.

- Portland Cement - This was used to solidify nitric acid, phosphoric acid, and sodium hydroxide in the bottom of the evaporator. The flash dried acid was reported to be very crumbly and not a solid monolith which will make cleanup efforts more difficult.

- Proparie - Some small cylinders from the maintenance or shop areas may be in the solid waste stream.

- Salts of Copper, Nickel, and Sulfate - These were used in the electroplating baths before 1970. Salt baths were also used in the heat treating of plutonium metal specimens. Salts were disposed of without any special packaging.

- Sodium - Extremely small quantities were stored in boxes.

- Sodium Hydroxide - This was used in the vibratory finisher project, resulting in a ceramic which was put into a sodium hydroxide tank. The waste form was a clay-like sludge in the bottom of the tank. This was then packed with absorbents and disposed of in 55-gal drums. It is estimated that a large amount of this waste form was routed to solid waste. Sodium hydroxide was also used as a neutralizing agent. It was made by dissolving small pellets in 1-gal or smaller bottles.

- Sodium Phosphate - This is listed as a contaminant in the $231-\mathrm{Z}$ burial records.

- Solvents - Many different solvents were used routinely at 231-Z. No attempt was made to rinse or stabilize solvents. Before the ban on free liquids, solvents were bagged and went out with no kitty litter or other absorbent. Organic solvents may found be in reagent bottles which were disposed of in 55-gal drums. 
- Sulfamic Acid - A very large quantity was used during processing. Sulfamic acid was also used in the dissolution of plutonium-clad metal parts. The acid was received as a powder, and was mixed with water before it was used. While sulfamic acid was normally routed to the $231-Z$ cribs, it is possible that some was disposed of in solid waste.

- Tantalum - Oxidized tantalum crucibles were used to hold plutonium metal during melting for casting processes.

- Tefion - Teflon tubes were used to contain specimens during spallation testing.

- Trichloroethane - No attempt was made to rinse or stabilize solvents. Before the ban on free liquids, solvents were bagged and went out without kitty litter or any other absorbent.

- Trichloroethylene - No attempt was made to rinse or stabilize solvents. Before the ban on free liquids, solvents were bagged and went out without kitty litter or any other absorbent.

- Tungsten - This is indicated as a component of the solid waste stream by interviewed personnel.

- Uranyl Nitrate - A small amount may have been made accidentally. This would have been disposed of in small beakers after being solidified in kitty litter.

- Uranyl Nitrate Hexahydrate - Very small amounts were stored in boxes at 231-Z.

- Vacuum Pump Oil - May be present as a contaminant in gloveboxes that were disposed of to solid waste.

- Zirconium - Metallurgical research generated large amounts of zirconium chips. Typically, these chips were either burned to an oxide outside of the 231-Z Building or were disposed of in cardboard boxes. Personnel did not recall any special precautions taken in the disposal of the zirconium chips.

\subsection{CLASSIFIED WASTE}

The vast majority of the work, which was performed during PNL's tenure at 231-Z, was classified. There is the possibility that some classified material or drawings may be contained in this waste, however, none of this waste has been officially designated as "classified".

\footnotetext{
Teflon is a trademark of E.I. duPont de Nemours and Company.
} 
Figure 5-1. 55-Gallon Drum Waste Count Generated by 231-2 Annually.
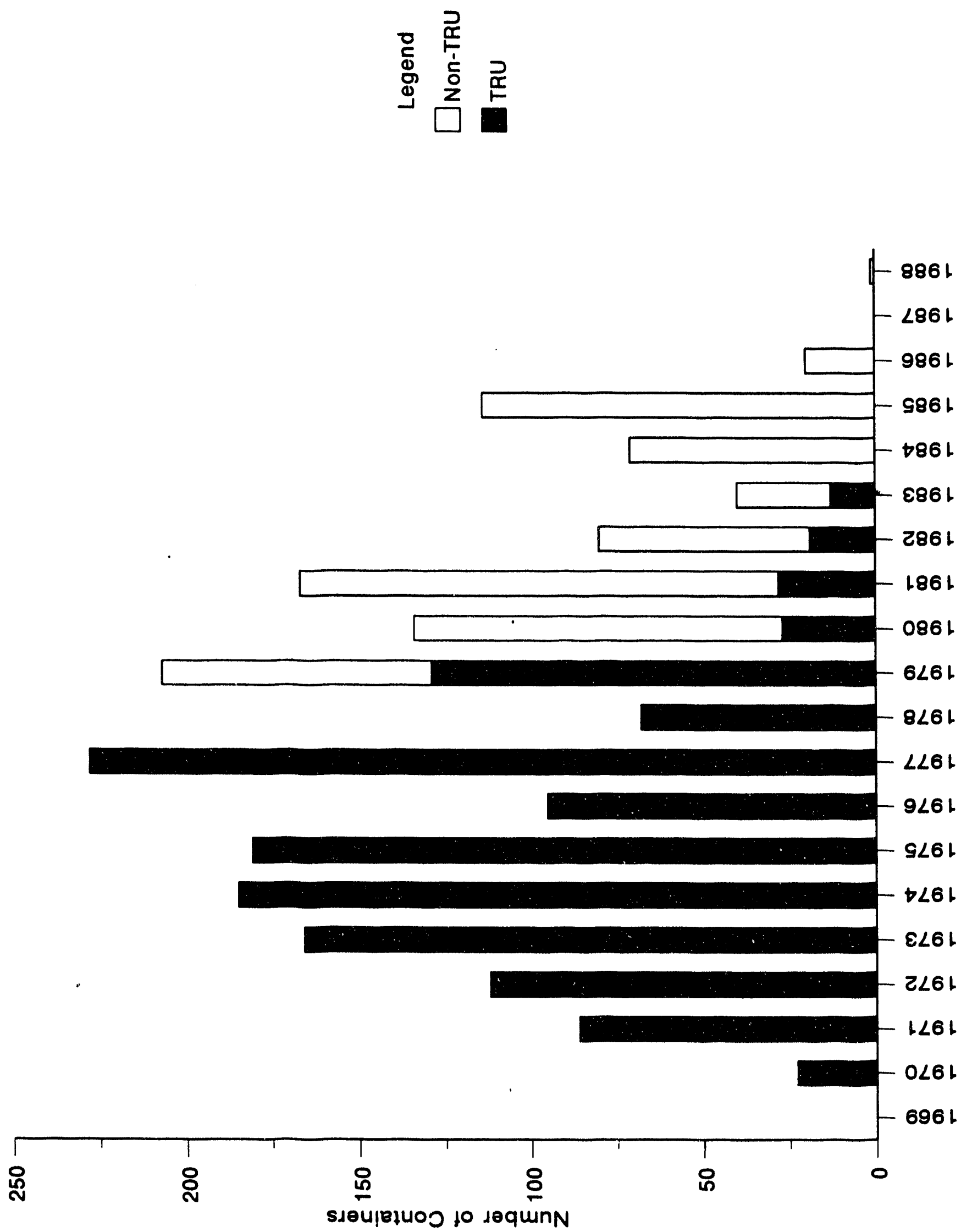


\section{WHC-EP-0659}

Figure 5-2. Percentage of 231-Z TRU/Non-TRU 55-Gallon Drums.

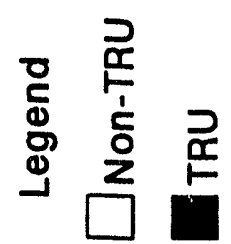

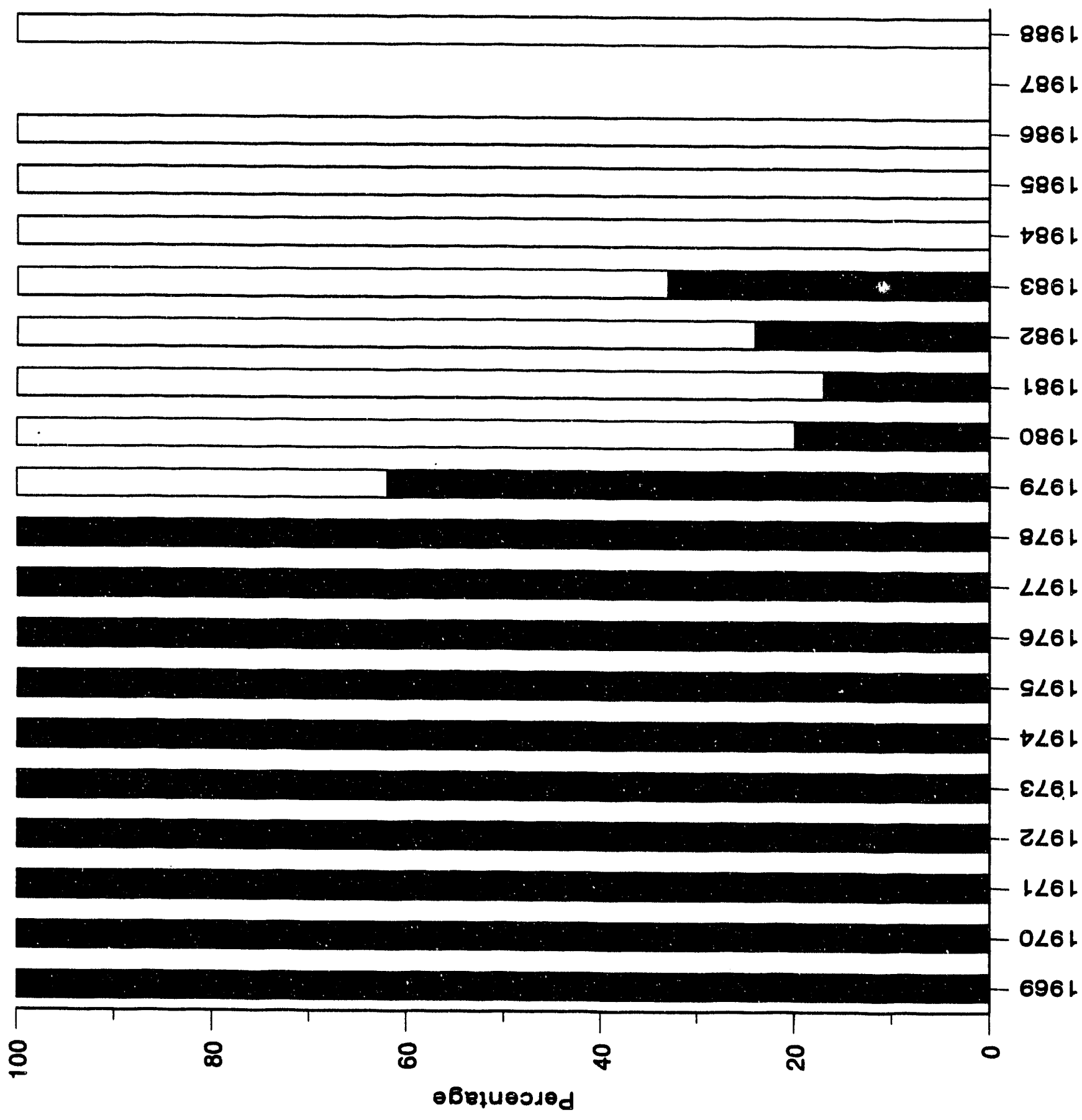


Figure 5-3. Weight of 55-Gallon Drum Waste Generated by 231-Z Annually.
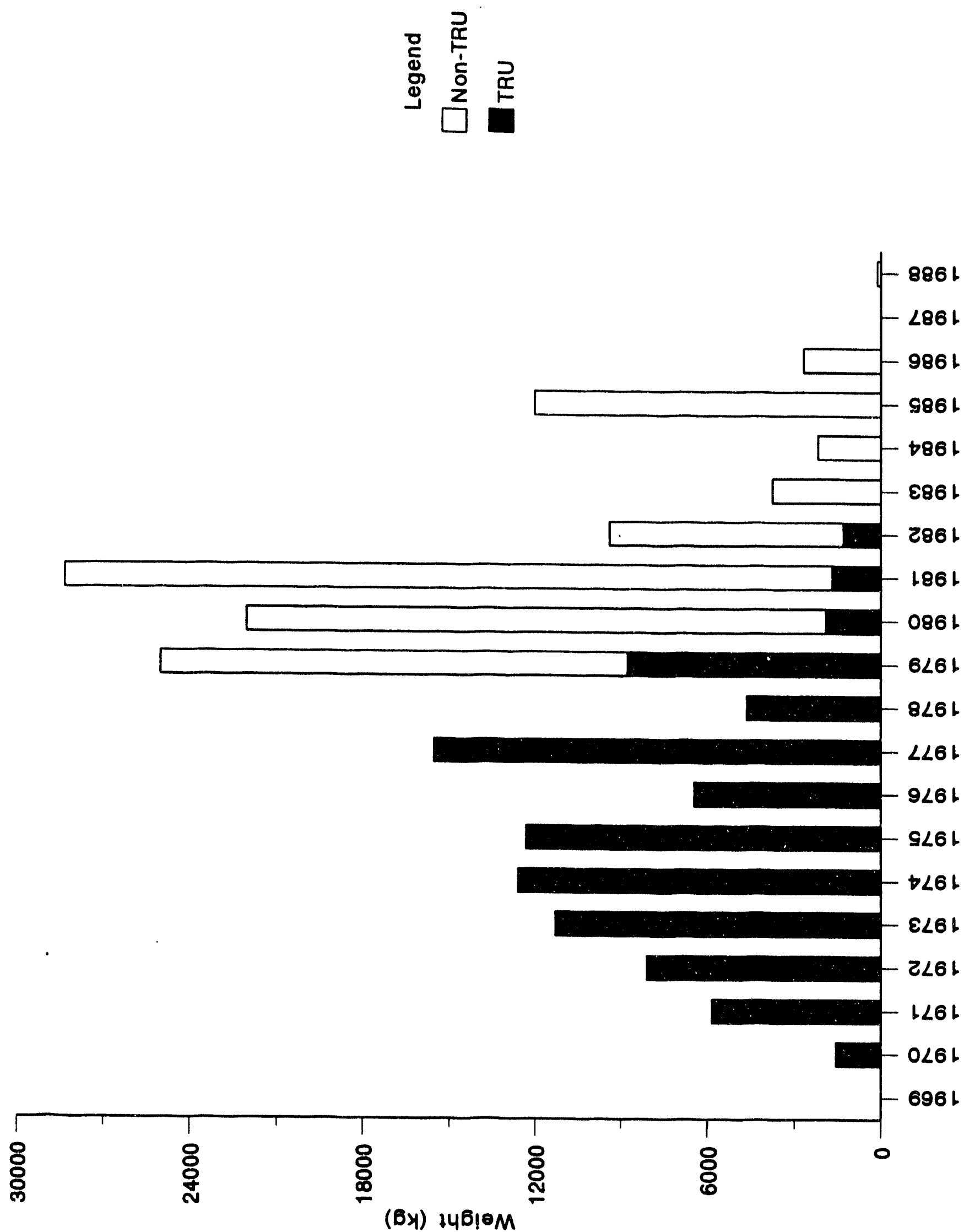
Figure 5-4. Weight Percentage of 231-Z 55-Gallon Drums.
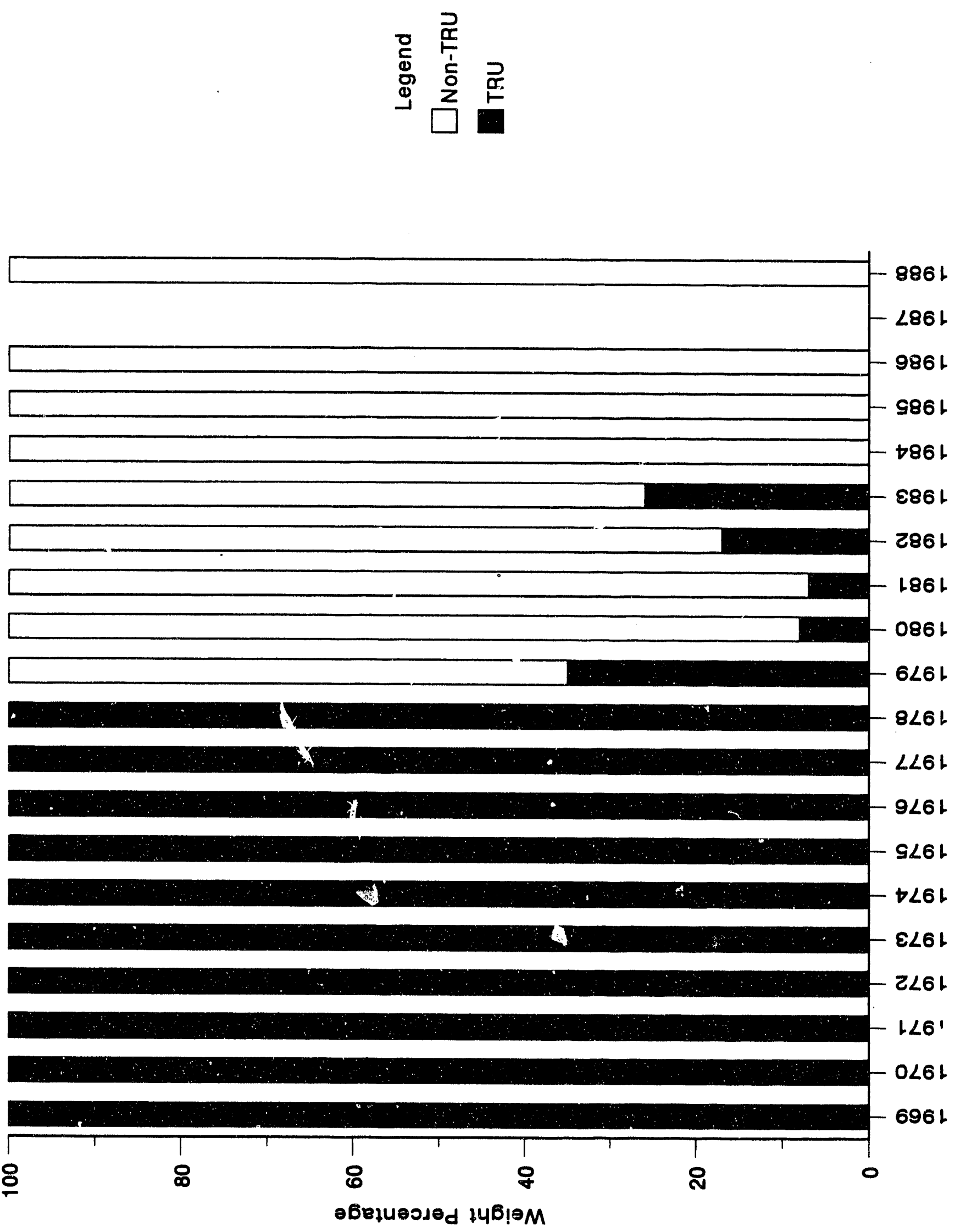


\section{WHC-EP-0659}

Figure 5-5. Volume of 55-Gallon Drum Waste Generated by 231-Z Annually.
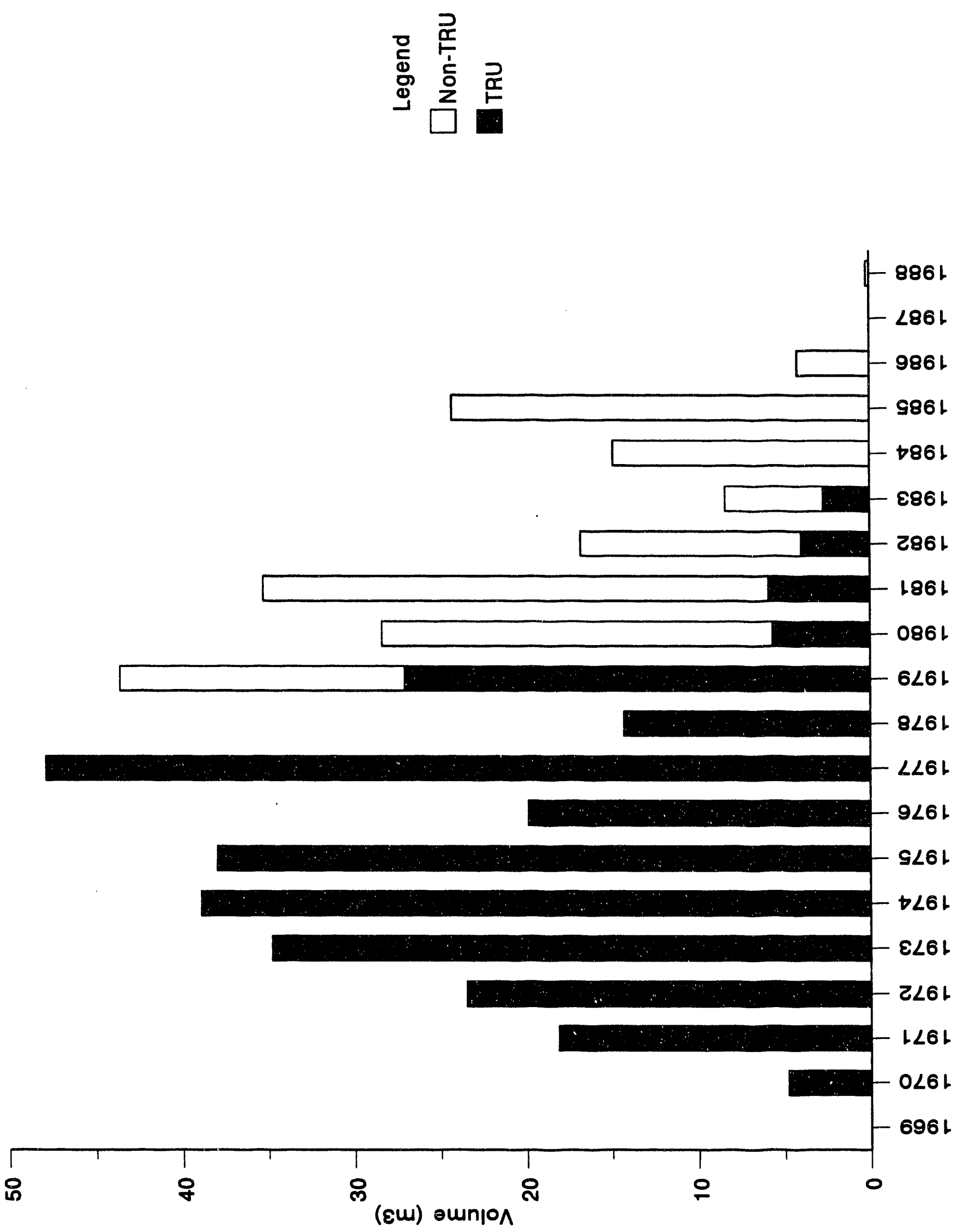
WHC-EP-0659

Figurg 5-6. Volume Percentage of 231-Z 55-Gallon Drums.
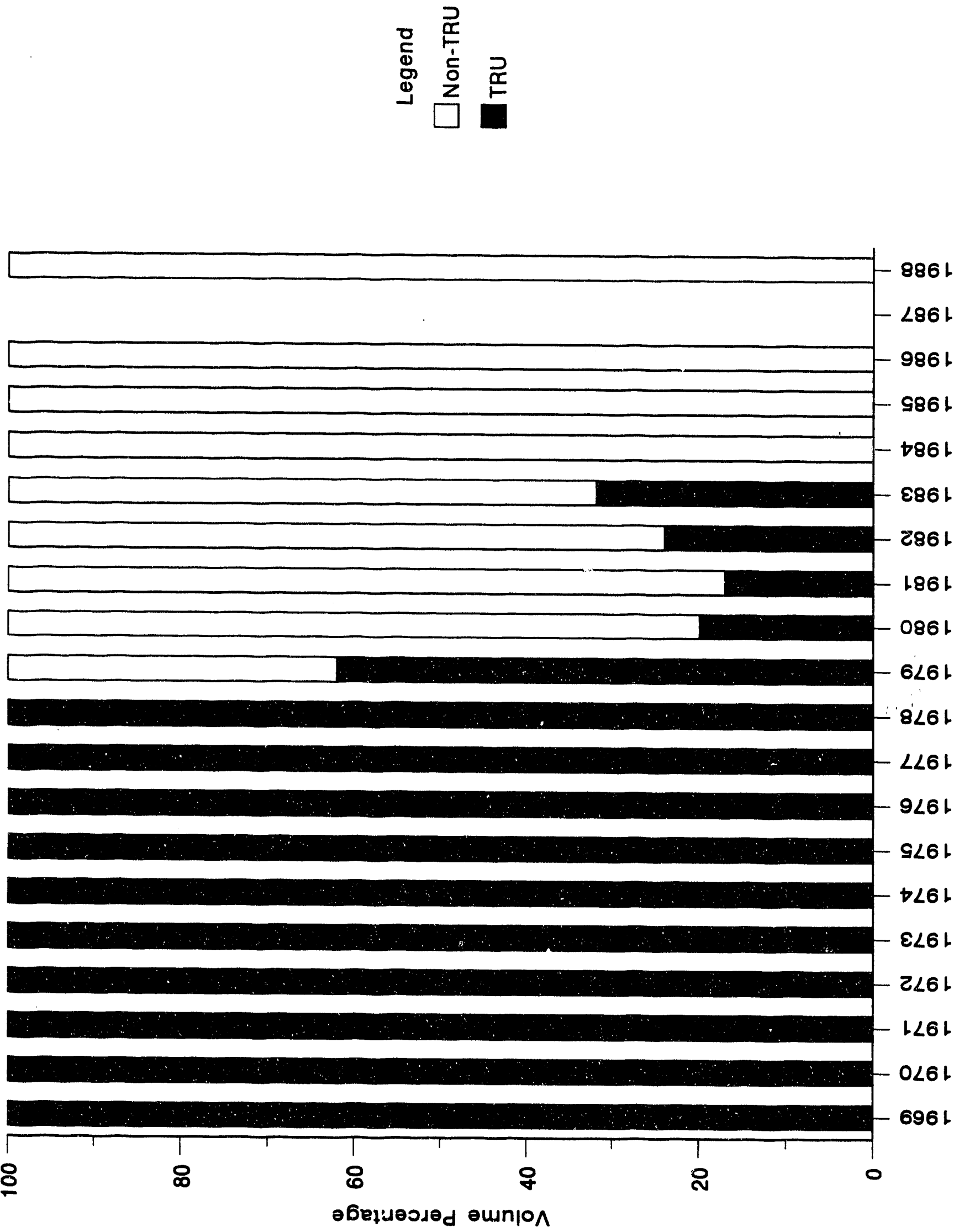
Figure 5-7. Other Container Waste Count Generated by 231-Z Annually.
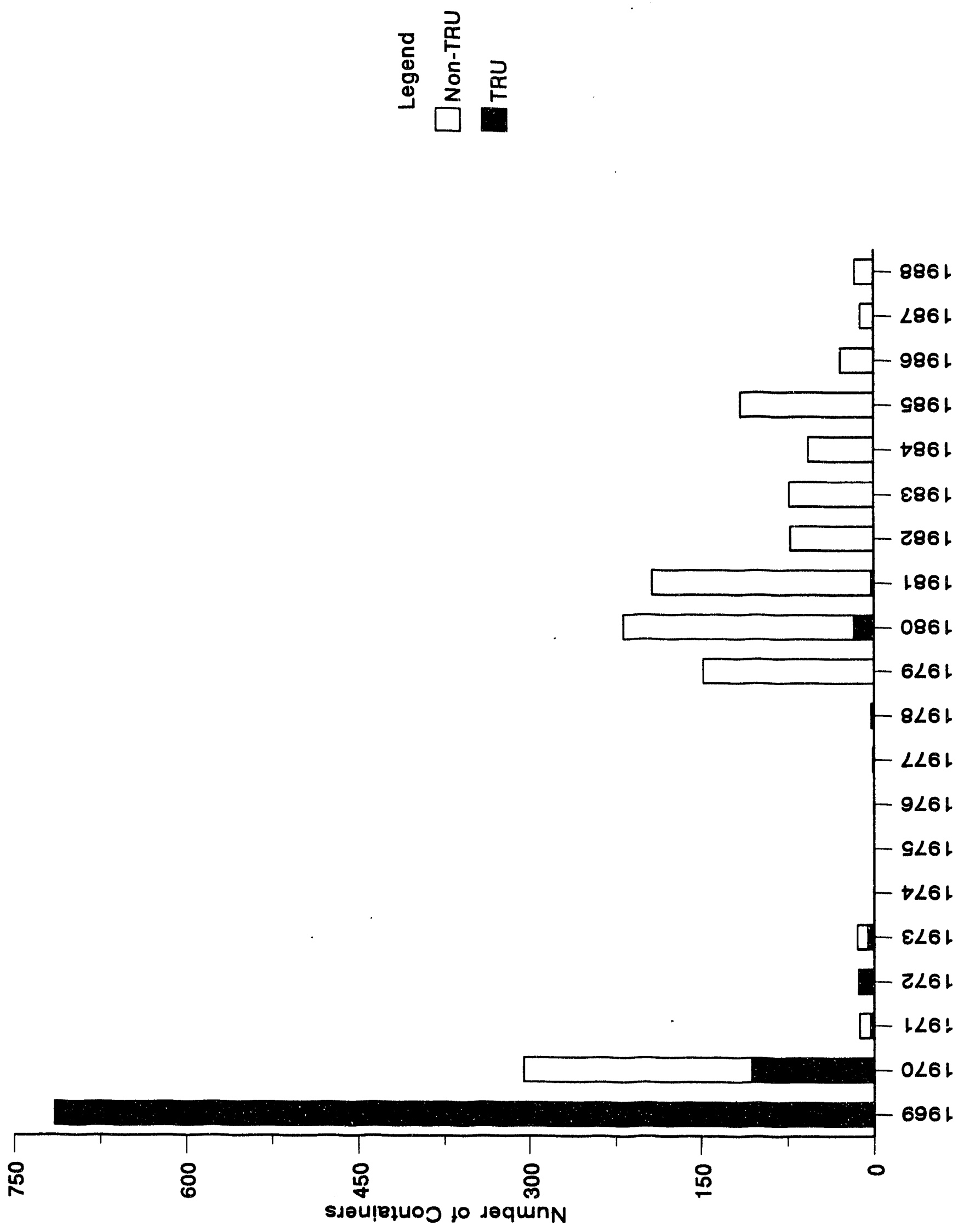
Figure 5-8. Percentage of 231-Z TRU/Non-TRU Other Containers.
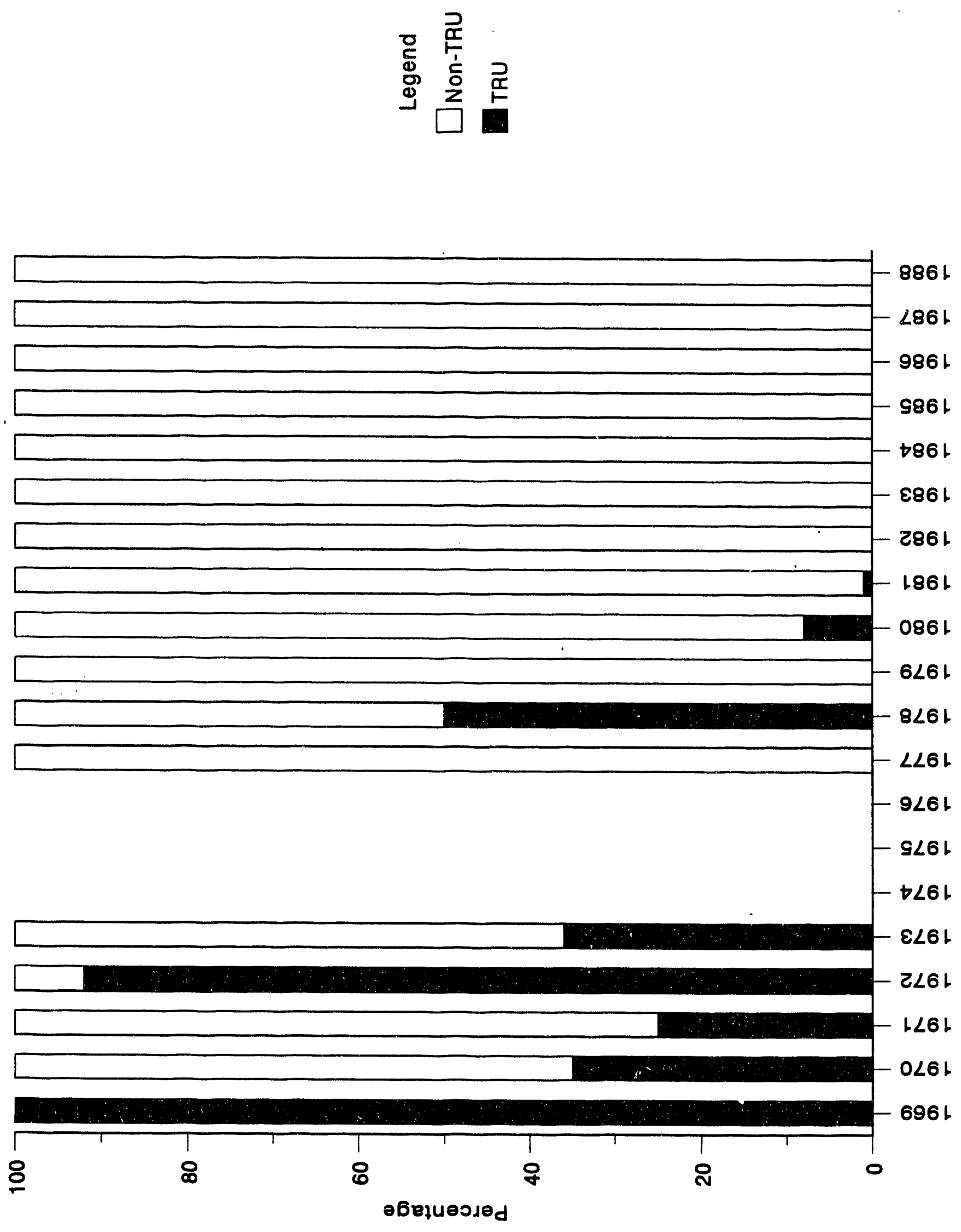
Figure 5-9. Weight of Other Containers Generated by 231-Z Annually.

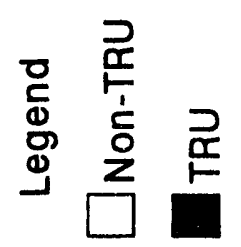

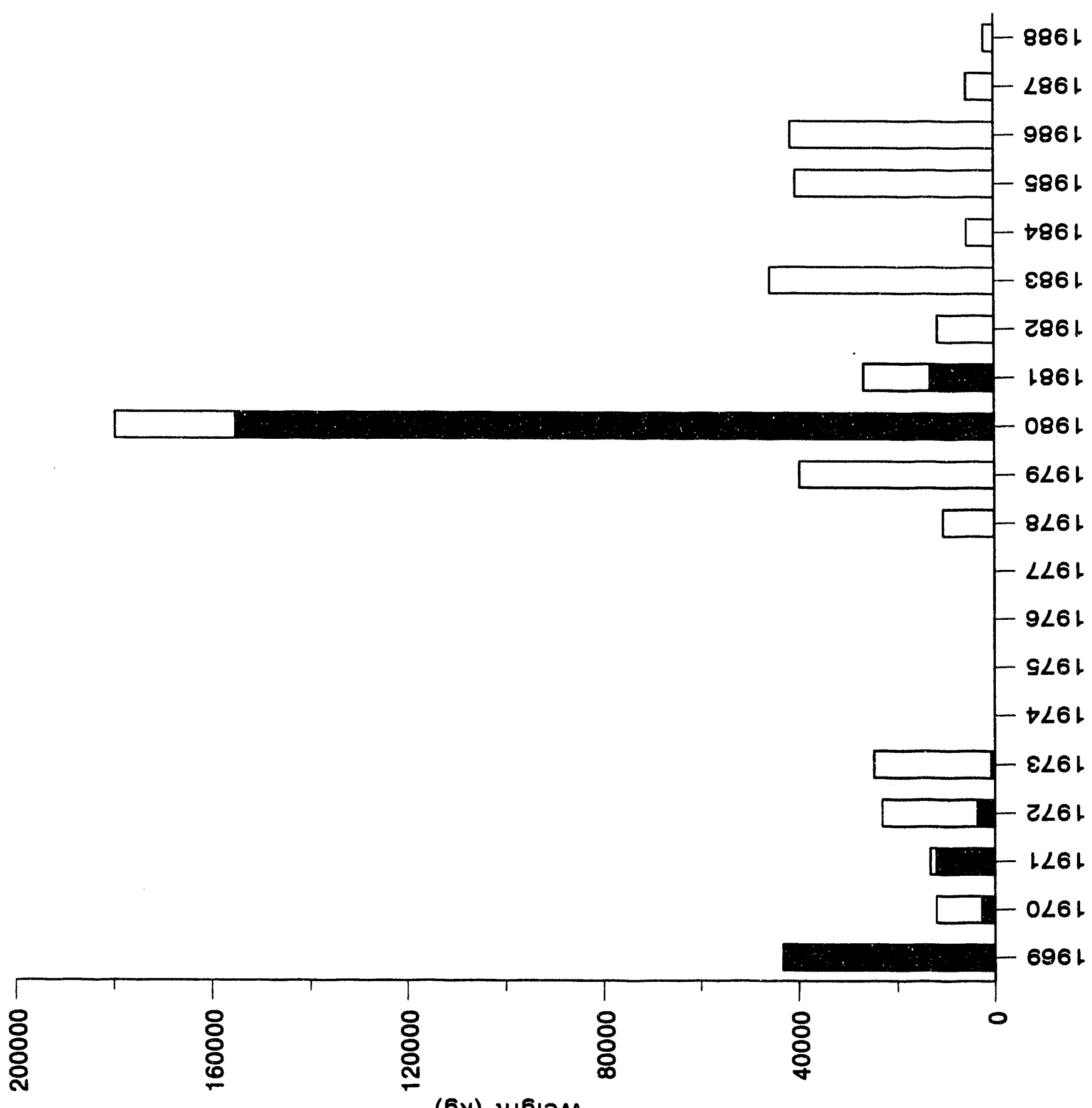

(6x) $146 ! \ominus M$ 
Figure 5-10. Weight Percentage of Other Containers Generated by 231-Z Annually.
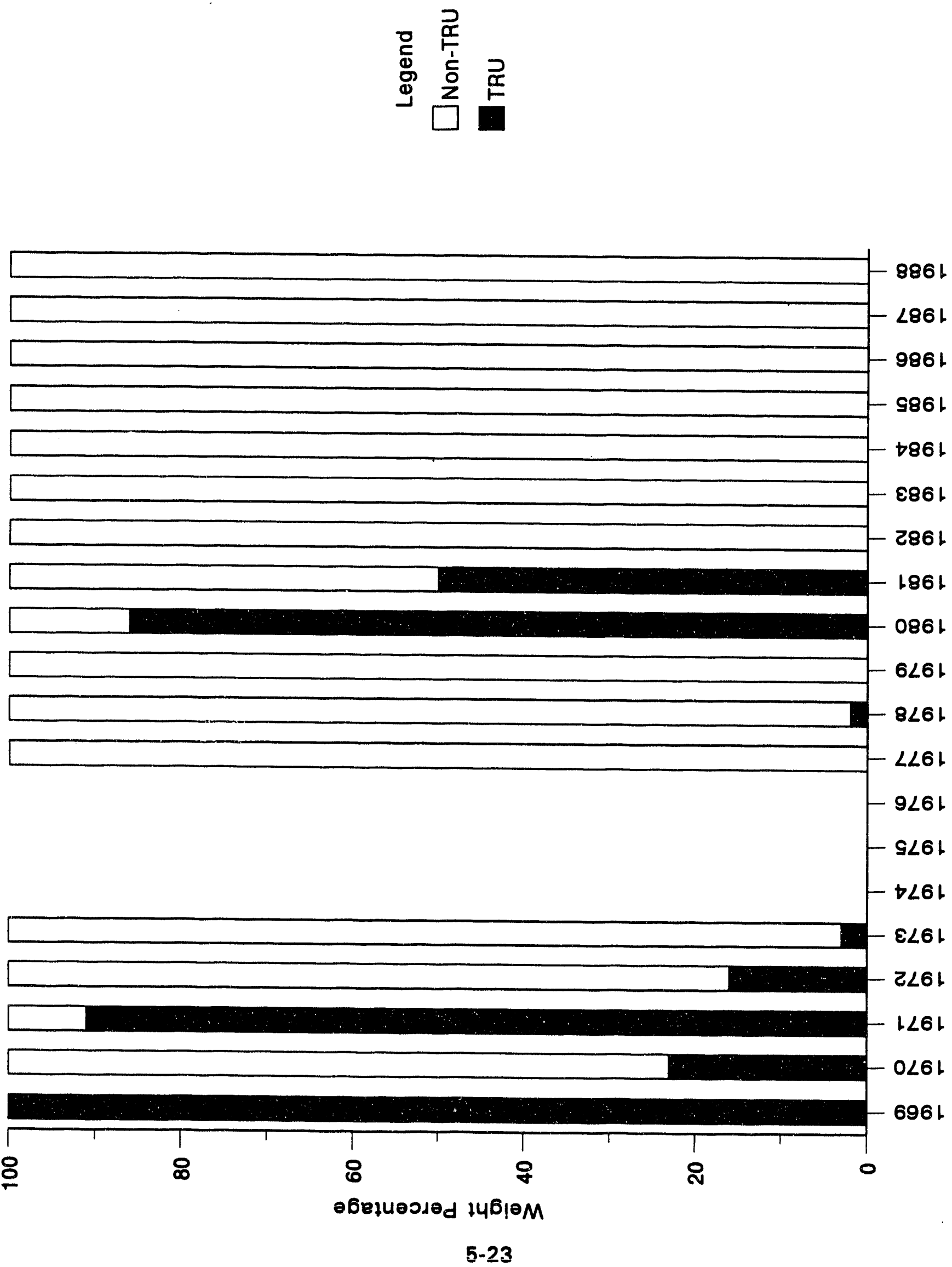


\section{WHC-EP-0659}

Figure 5-11. Volume of Other Containers Generated by 231-Z Annually.

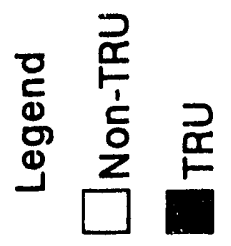

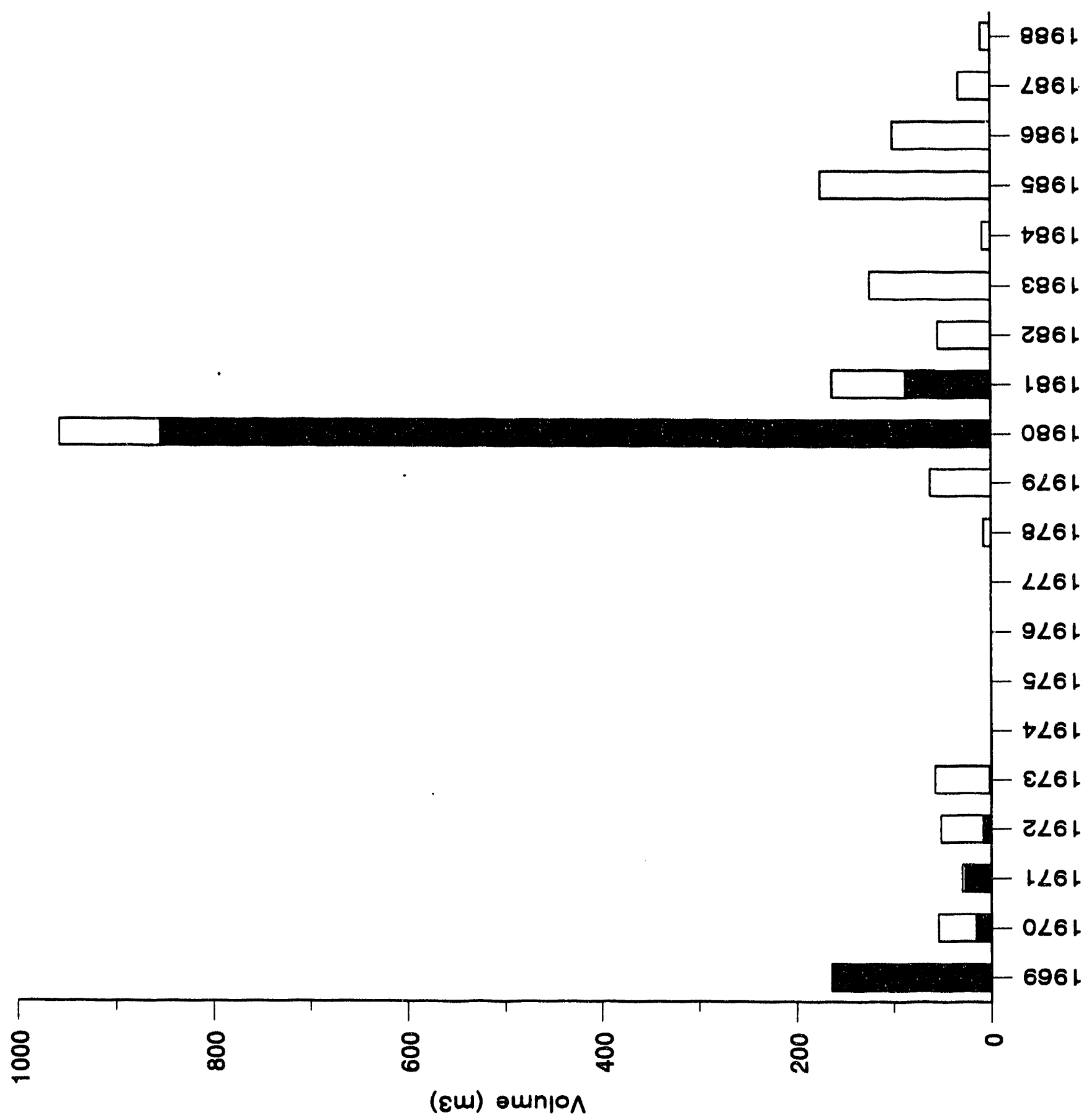


Figure 5-12. Volume Percentage of Other Containers Generated by 231-Z Annually.
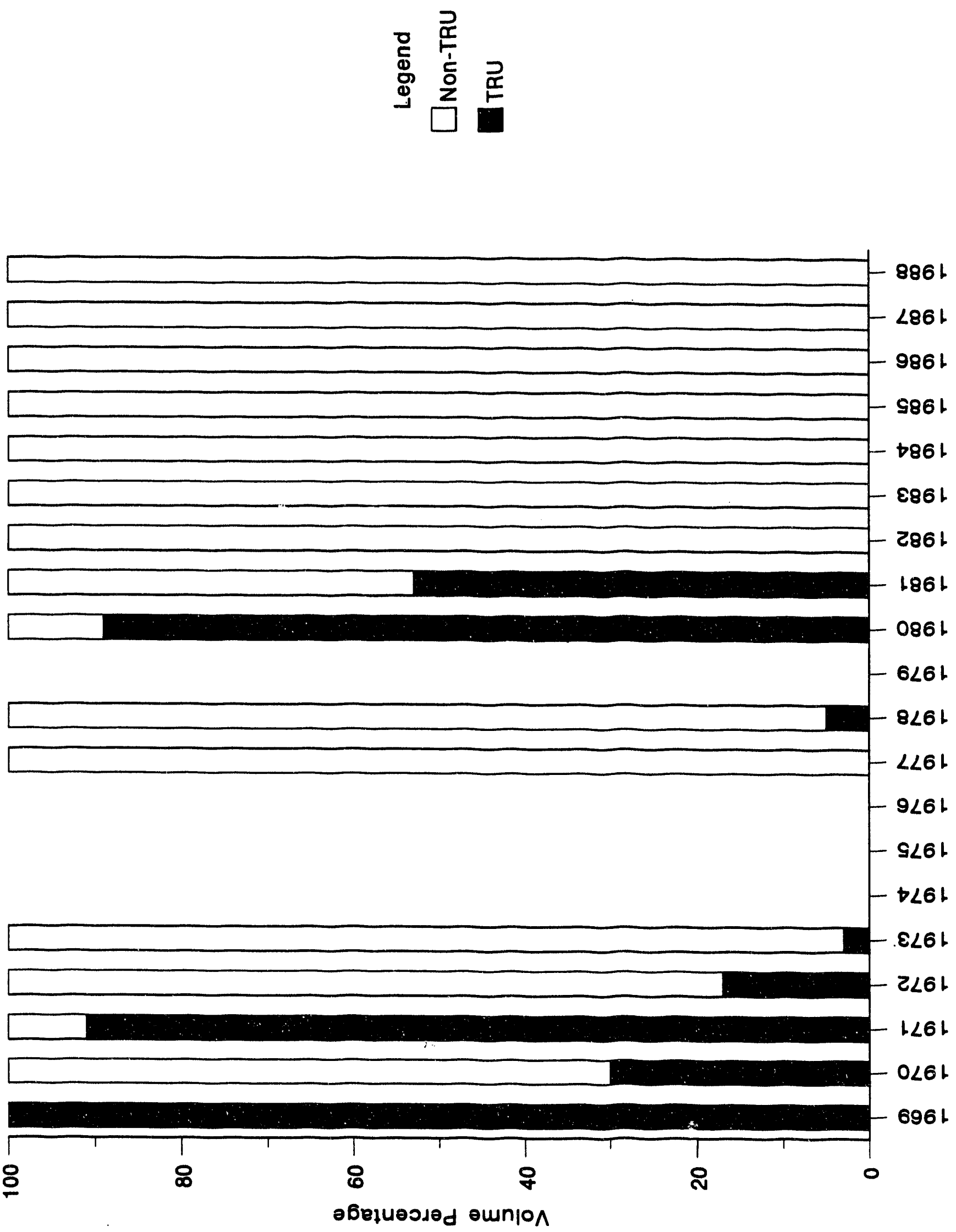


\section{WHC-EP-0659}

Figure 5-13. Total Number of Waste Containers Generated by 231-Z Annually.
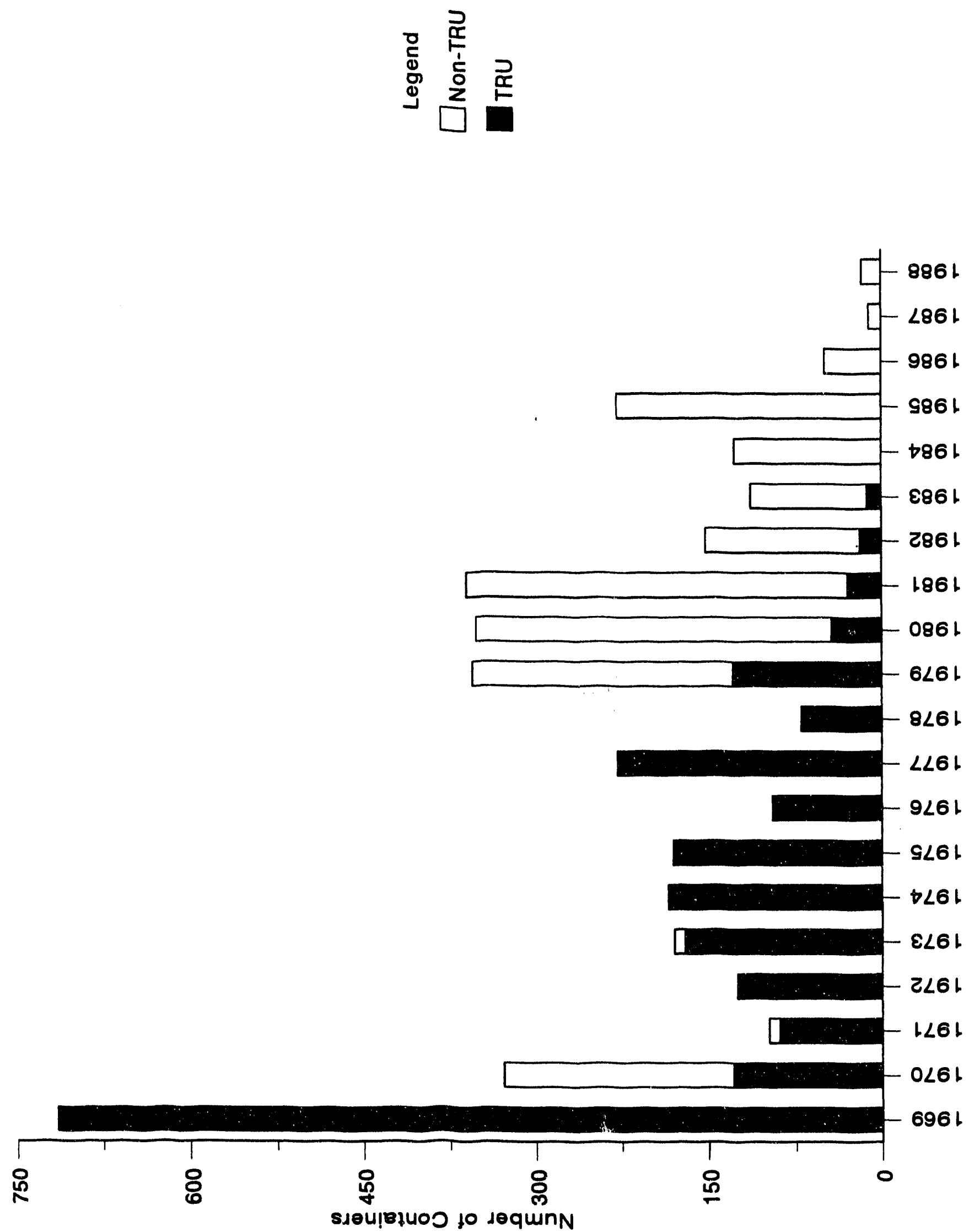
Figure 5-14. Total Weight of Waste Generated by 231-z Annually.
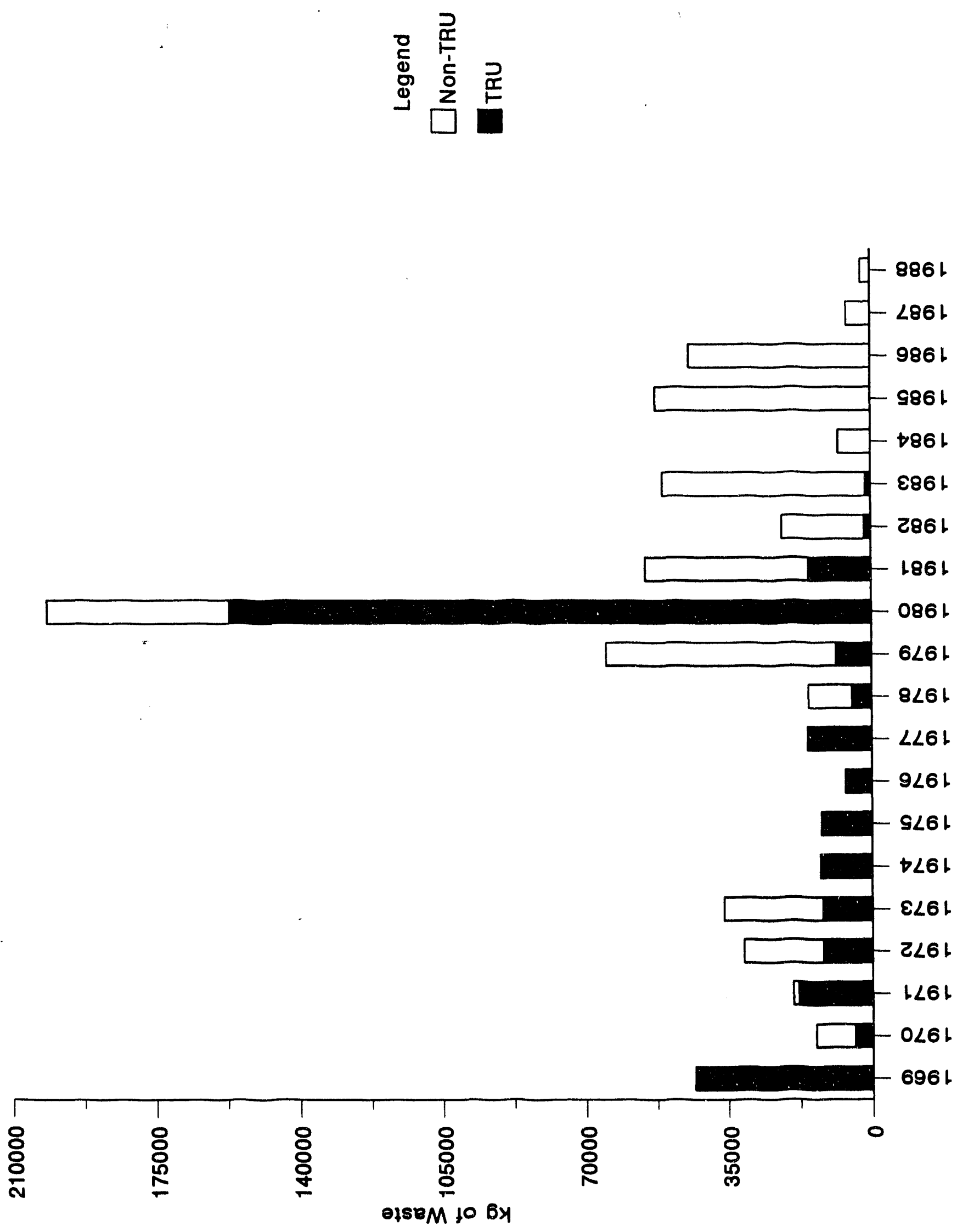
Figure 5-15. Total Volume of Waste Generated by 231-Z Annually.
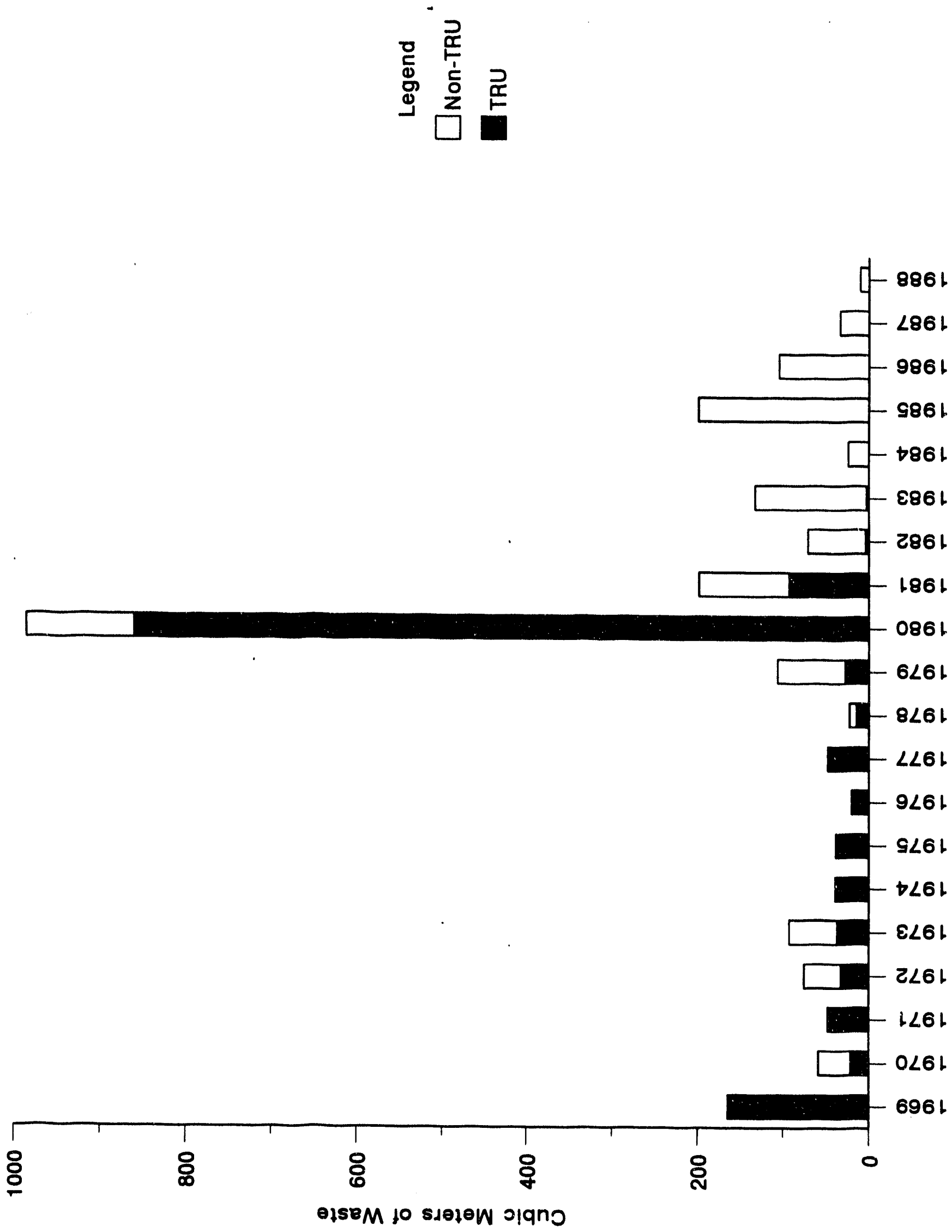
WHC-EP-0659

Figure 5-16. Grams of TRU Waste Generated by 231-Z Annually.
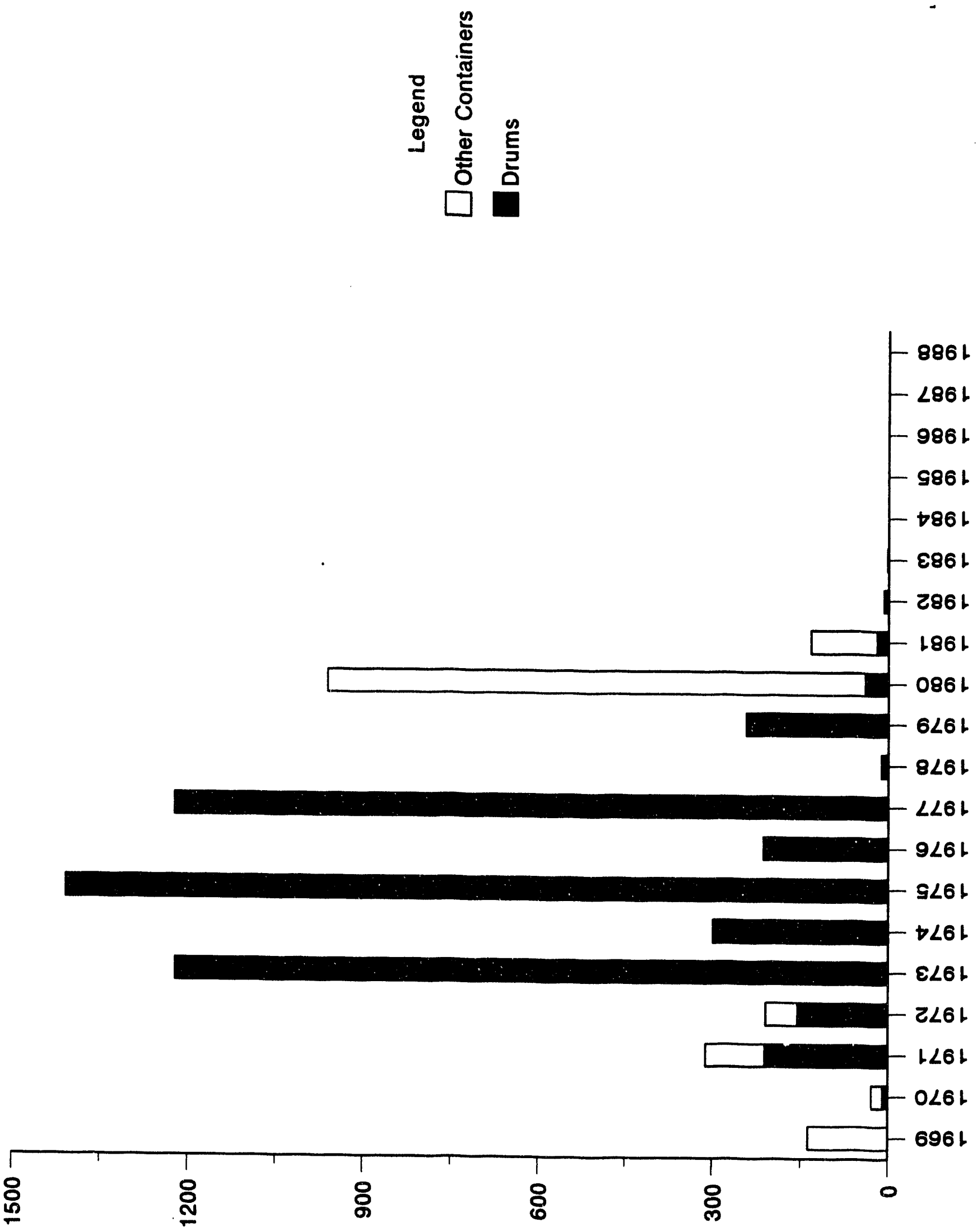

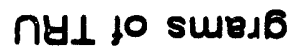


Table 5-1. TRU Waste Generated at 231-Z by Container Type and Year. (3 sheets)

\begin{tabular}{|c|c|c|c|c|c|c|c|}
\hline Container type & $\begin{array}{l}\text { Container } \\
\text { size }\end{array}$ & $\begin{array}{l}\text { Container } \\
\text { number }\end{array}$ & $\begin{array}{l}\text { Percent } \\
\text { of total }\end{array}$ & $\begin{array}{l}\text { Total } \\
\text { container } \\
\text { weight } \\
\text { (kg) }\end{array}$ & $\begin{array}{l}\text { Percent } \\
\text { weight }\end{array}$ & $\begin{array}{l}\text { Volume } \\
\left(\mathrm{m}^{3}\right)\end{array}$ & $\begin{array}{l}\text { Percent } \\
\text { volume }\end{array}$ \\
\hline \multicolumn{8}{|c|}{1969} \\
\hline \multirow{2}{*}{$\begin{array}{l}\text { Fiberboard/plastic boxes, } \\
\text { cartons, and gases }\end{array}$} & $2 \mathrm{ft}^{3}$ & 3 & $0.4 \%$ & 16 & $<0.1 \%$ & 0.1 & $0.1 \%$ \\
\hline & unknown & 688 & $96.2 \%$ & 8738 & $20.2 \%$ & 87.2 & $53.1 \%$ \\
\hline $\begin{array}{l}\text { Trucks, flatbeds, } \\
\text { compactor, loadlugger }\end{array}$ & unknown & 20 & $2.8 \%$ & 32537 & $75.1 \%$ & 72.5 & $44.1 \%$ \\
\hline \multirow{3}{*}{$\begin{array}{l}\text { Wooden boxes, cartons, } \\
\text { and cases }\end{array}$} & $2 \times 4 \times 8 \mathrm{ft}$ & 1 & $0.1 \%$ & 610 & $1.4 \%$ & 1.4 & $0.8 \%$ \\
\hline & $3 \times 5 \times 5 \mathrm{ft}$ & 1 & $0.1 \%$ & 8676 & $2.0 \%$ & 1.9 & $1.1 \%$ \\
\hline & unknown & 2 & $0.3 \%$ & 521 & $1.2 \%$ & 1.2 & $0.7 \%$ \\
\hline \multicolumn{2}{|l|}{ Total } & 715 & & 43298 & & 164.3 & \\
\hline \multicolumn{8}{|c|}{1970} \\
\hline \multirow{2}{*}{$\begin{array}{l}\text { Fiberboard/plastic boxes, } \\
\text { cartons, and cases }\end{array}$} & $2 \mathrm{ft}^{3}$ & 2 & $1.6 \%$ & 24 & $0.5 \%$ & 0.1 & $0.5 \%$ \\
\hline & unknown & 99 & $76.7 \%$ & 1257 & $28.7 \%$ & 12.6 & $59.7 \%$ \\
\hline \multirow{2}{*}{$\begin{array}{l}\text { Metal drums, barrels, or } \\
\text { kegs }\end{array}$} & $30 \mathrm{gal}$ & 4 & $3.1 \%$ & 163 & $3.7 \%$ & 0.5 & $2.4 \%$ \\
\hline & $55 \mathrm{gal}$ & 23 & $17.8 \%$ & 1565 & $35.7 \%$ & 4.8 & 22.70 \\
\hline $\begin{array}{l}\text { Trucks, flatbeds, } \\
\text { compactors, loadluggers }\end{array}$ & unknown & 1 & $0.8 \%$ & 1372 & $31.3 \%$ & 3.1 & 14.7 \\
\hline Total & & 129 & & 4381 & & 21.1 & \\
\hline \multicolumn{8}{|c|}{1971} \\
\hline Gloveboxes & unknown & 1 & $1.1 \%$ & 11430 & $63.3 \%$ & 25.5 & $56.2 \%$ \\
\hline $\begin{array}{l}\text { Metal drums, barrels, or } \\
\text { kegs }\end{array}$ & $55 \mathrm{gal}$ & 86 & $96.6 \%$ & 5851 & $32.4 \%$ & 18.1 & $39.9 \%$ \\
\hline Miscellaneous scrap & unknown & 1 & $1.1 \%$ & 356 & $2.0 \%$ & 0.9 & $2.0 \%$ \\
\hline Self-contained equipment & unknown & 1 & $1.1 \%$ & 408 & $2.3 \%$ & 0.9 & $2.0 \%$ \\
\hline \multicolumn{2}{|l|}{ Total } & \multicolumn{2}{|l|}{89} & 18045 & & 45.4 & \\
\hline \multicolumn{8}{|c|}{1972} \\
\hline \multirow{2}{*}{$\begin{array}{l}\text { Metal boxes, carton, and } \\
\text { cases }\end{array}$} & $2 \times 2 \times 3 \mathrm{ft}$ & 11 & $8.9 \%$ & 1677 & $14.1 \%$ & 3.7 & $11.6 \%$ \\
\hline & $3.5 \times 6 \times 8 \mathrm{ft}$ & 1 & $0.8 \%$ & 2136 & $17.9 \%$ & 4.8 & $15.0 \%$ \\
\hline \multirow{2}{*}{$\begin{array}{l}\text { Metal drums, barrels, or } \\
\text { kegs }\end{array}$} & $55 \mathrm{gal}^{\circ}$ & 10 & $8.1 \%$ & 706 & $5.9 \%$ & 2.1 & $6.6 \%$ \\
\hline & $55 \mathrm{gal}$ & 102 & $82.3 \%$ & 7405 & $62.1 \%$ & 21.4 & $66.9 \%$ \\
\hline Total & & 124 & & 11924 & & 32.0 & \\
\hline
\end{tabular}


Table 5-1. TRU Waste Generated at 231-z by Container Type and Year. (3 sheets)

\begin{tabular}{|c|c|c|c|c|c|c|c|}
\hline Container yype & Container: & Crntainer & $\begin{array}{l}\text { Percent } \\
\text { of total }\end{array}$ & $\begin{array}{l}\text { Total } \\
\text { container } \\
\text { weight } \\
(\mathrm{kg})\end{array}$ & $\begin{array}{l}\text { Percent } \\
\text { weight }\end{array}$ & $\begin{array}{l}\text { Volume } \\
\left(\mathrm{m}^{3}\right)\end{array}$ & $\begin{array}{l}\text { Percent } \\
\text { volume }\end{array}$ \\
\hline \multicolumn{8}{|c|}{1973 . } \\
\hline $\begin{array}{l}\text { Metal boxes, cartons, and } \\
\text { cases }\end{array}$ & $2 \times 2 \times 3 \mathrm{ft}$ & 5 & $2.9 \%$ & 762 & $6.3 \%$ & 1.7 & $4.7 \%$ \\
\hline \multirow{2}{*}{$\begin{array}{l}\text { Metal drums, barrels, or } \\
\text { kegs }\end{array}$} & $55 \mathrm{gal}^{\circ}$ & 4 & $2.3 \%$ & 272 & $2.6 \%$ & 0.8 & $2.2 \%$ \\
\hline & $55 \mathrm{gal}$ & 162 & $94.7 \%$ & 11022 & $91.4 \%$ & 34.0 & $93.2 \%$ \\
\hline Totel & & 171 & & 12056 & & 36.5 & \\
\hline \multicolumn{8}{|c|}{1974 . } \\
\hline $\begin{array}{l}\text { Metal drums, barrels, or } \\
\text { kegs }\end{array}$ & $55 \mathrm{gal}^{\circ}$ & 185 & $100.0 \%$ & 12587 & $100.0 \%$ & 38.9 & $100.0 \%$ \\
\hline Total & & 185 & & 12587 & & 38.9 & \\
\hline \multicolumn{8}{|c|}{1975} \\
\hline \multirow{2}{*}{$\begin{array}{l}\text { Metal drums, barrels, or } \\
\text { kegs }\end{array}$} & $55 \mathrm{gal}^{\circ}$ & 2 & $1.1 \%$ & 136 & $1.1 \%$ & 0.4 & $1.1 \%$ \\
\hline & $55 \mathrm{gal}$ & 179 & $98.9 \%$ & 12179 & $98.9 \%$ & 37.6 & $98.9 \%$ \\
\hline Total & & 181 & & 12315 & & 38.0 & \\
\hline \multicolumn{8}{|c|}{1976 . } \\
\hline \multirow{2}{*}{$\begin{array}{l}\text { Metal drums, barrels, or } \\
\text { kegs }\end{array}$} & $55 \mathrm{gal}$ & 1 & $1.1 \%$ & 68 & $1.1 \%$ & 0.2 & $1.0 \%$ \\
\hline & $55 \mathrm{gal}$ & 94 & $98.9 \%$ & 6396 & $98.9 \%$ & 19.7 & $99.0 \%$ \\
\hline Total & & 95 & & 6464 & & 19.9 & \\
\hline \multicolumn{8}{|c|}{1977 . } \\
\hline $\begin{array}{l}\text { Metal drums, barrels, or } \\
\text { kegs }\end{array}$ & $55 \mathrm{gal}$ & 228 & $100.0 \%$ & 15513 & $100.0 \%$ & 47.9 & $100.0 \%$ \\
\hline Total & & 228 & & 15513 & & 47.9 & \\
\hline \multicolumn{8}{|c|}{1978} \\
\hline $\begin{array}{l}\text { Metal boxes, cartons, and } \\
\text { cases }\end{array}$ & $2 \times 2 \times 3 \mathrm{ft}$ & 1 & $1.4 \%$ & 175 & $3.6 \%$ & 0.4 & $2.7 \%$ \\
\hline $\begin{array}{l}\text { Metal drums, barrels, or } \\
\text { kegs }\end{array}$ & $55 \mathrm{gal}$ & 68 & $98.6 \%$ & 467 & $96.4 \%$ & 14.3 & $97.3 \%$ \\
\hline Total & & 69 & & 4802 & & 14.7 & \\
\hline \multicolumn{8}{|c|}{1979} \\
\hline $\begin{array}{l}\text { Metal drums, barrels, or } \\
\text { kegs }\end{array}$ & $55 \mathrm{gal}$ & 129 & $100.0 \%$ & 8773 & $100.0 \%$ & 27.1 & $100.0 \%$ \\
\hline Toted & & 129 & & 8773 & & 27.1 & \\
\hline
\end{tabular}


Table 5-1. TRU Waste Generated at $231-\mathrm{Z}$ by Container Type and Year. (3 sheets)

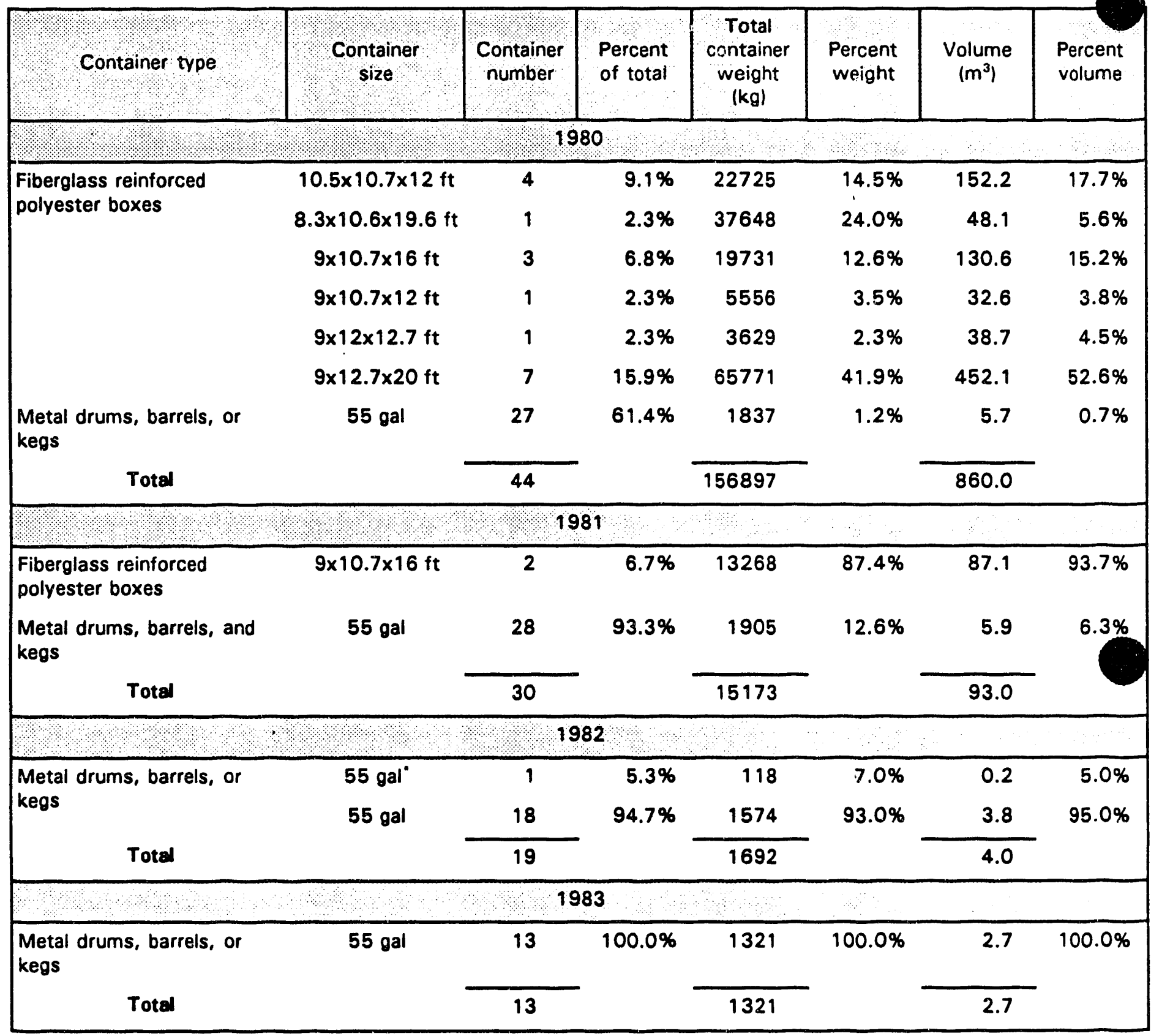

- These containers hold mixed waste. 
Table 5-2. Non-TRU Waste Generated at 231-Z by Container Type and Year. (4 sheets)

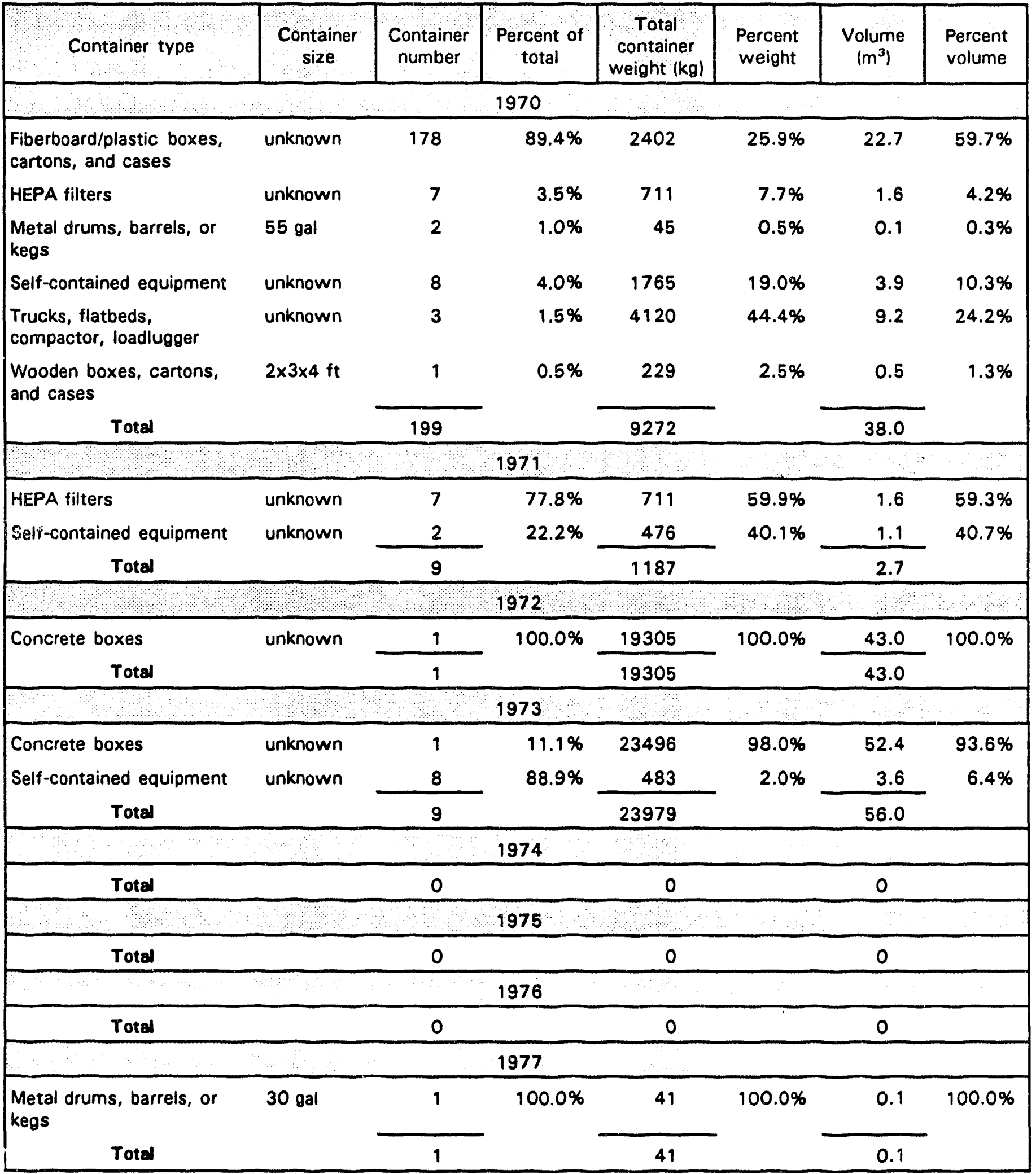


Table 5-2. Non-TRU Waste Generated at 231-Z by Container Type and Year. (4 sheets)

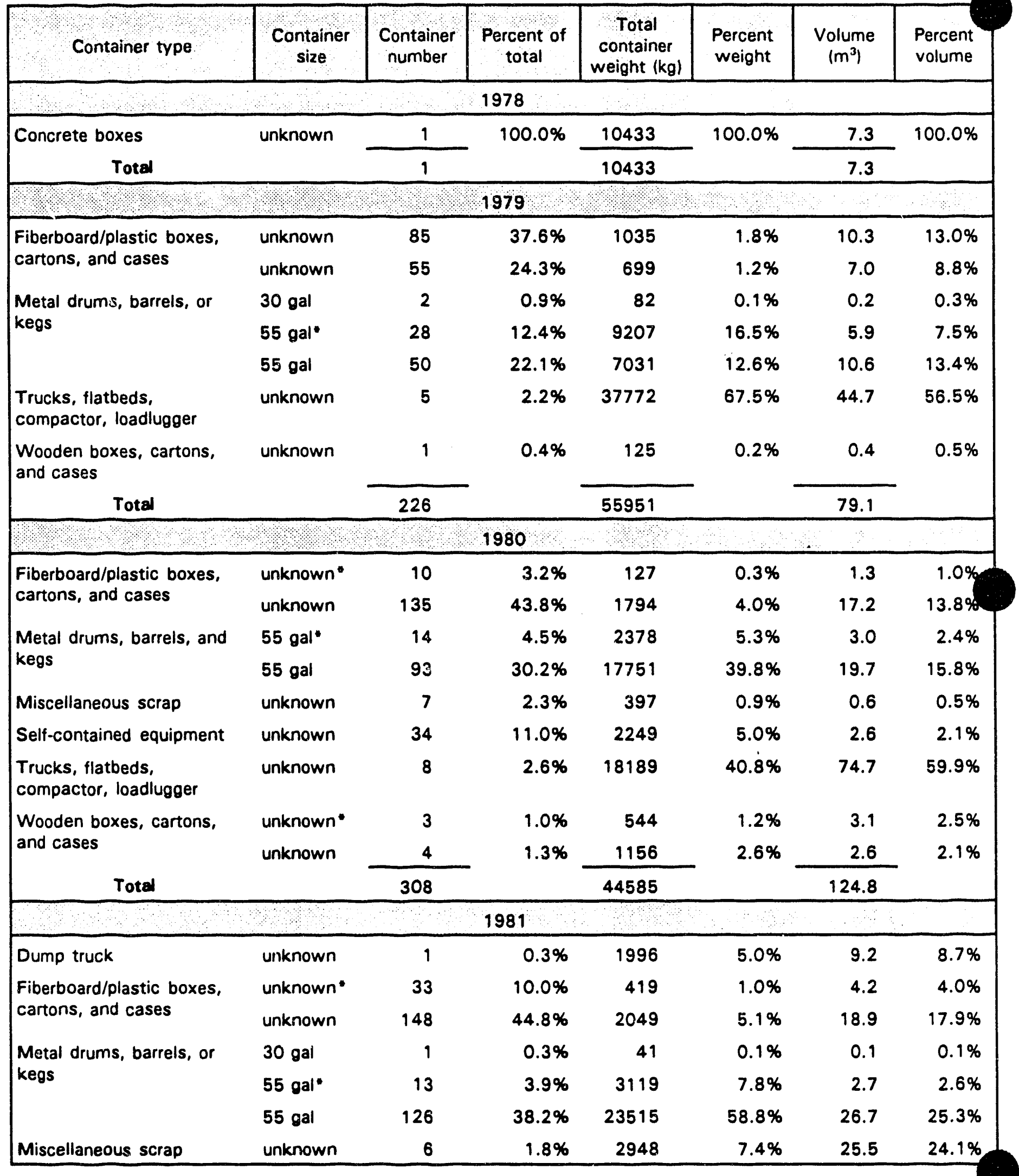


Table 5-2. Non-TRU Waste Generated at 231-Z by Container Type and Year. (4 sheets)

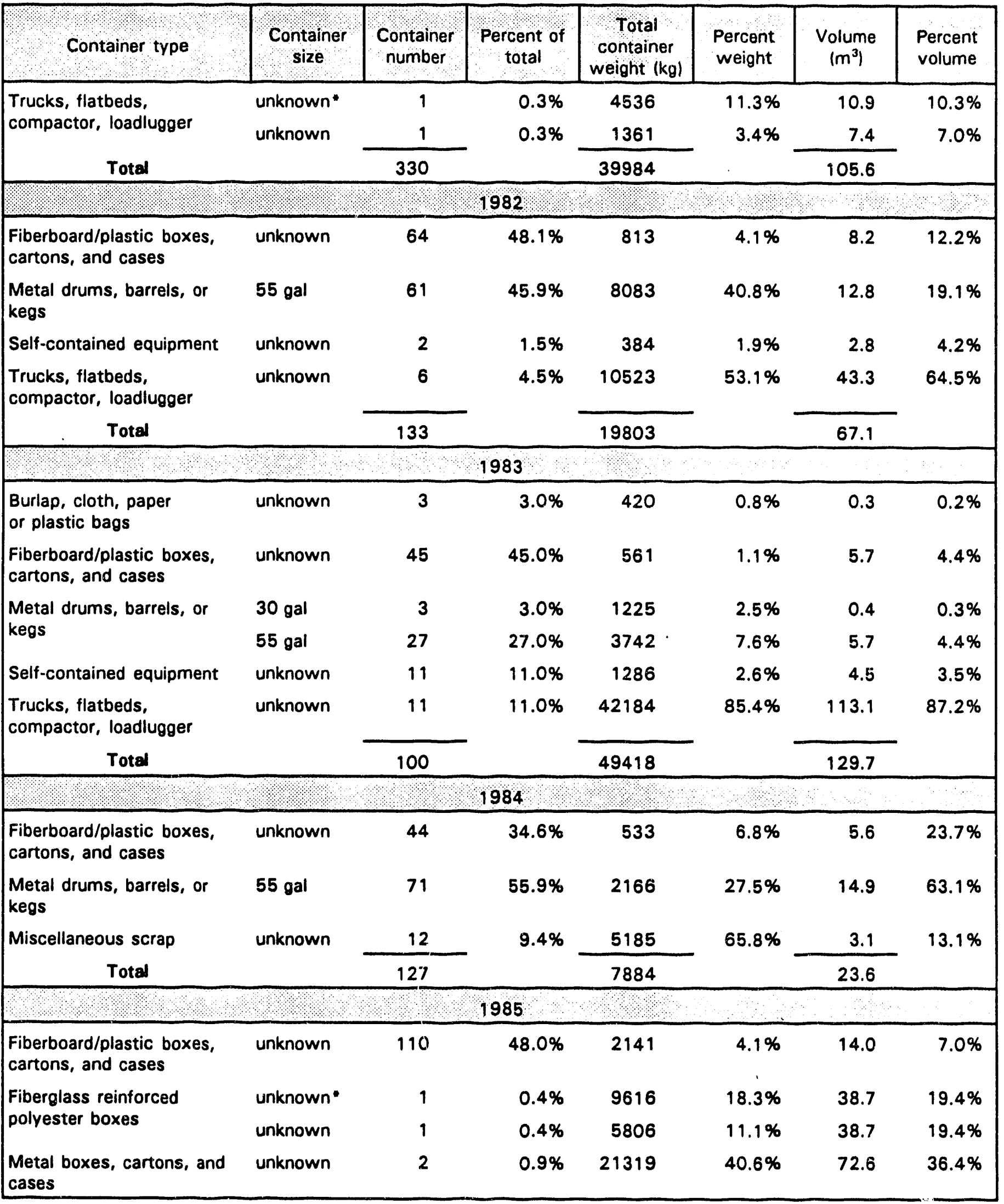


Table 5-2. Non-TRU Waste Generated at 231-Z by Container Type and Year. (4 sheets)

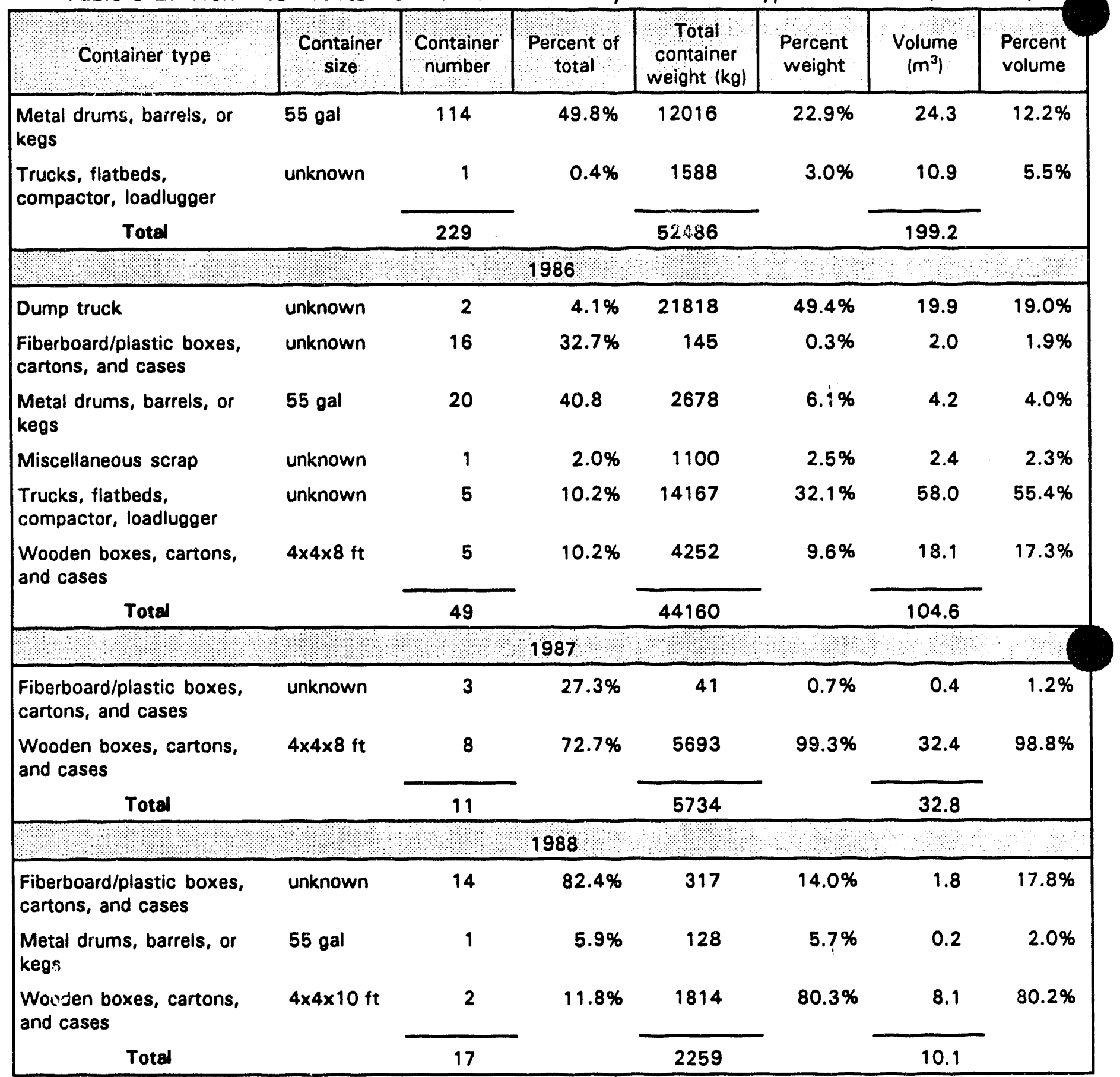

HEPA = High-efficiency particulate air.

- These containers hold mixed waste. 


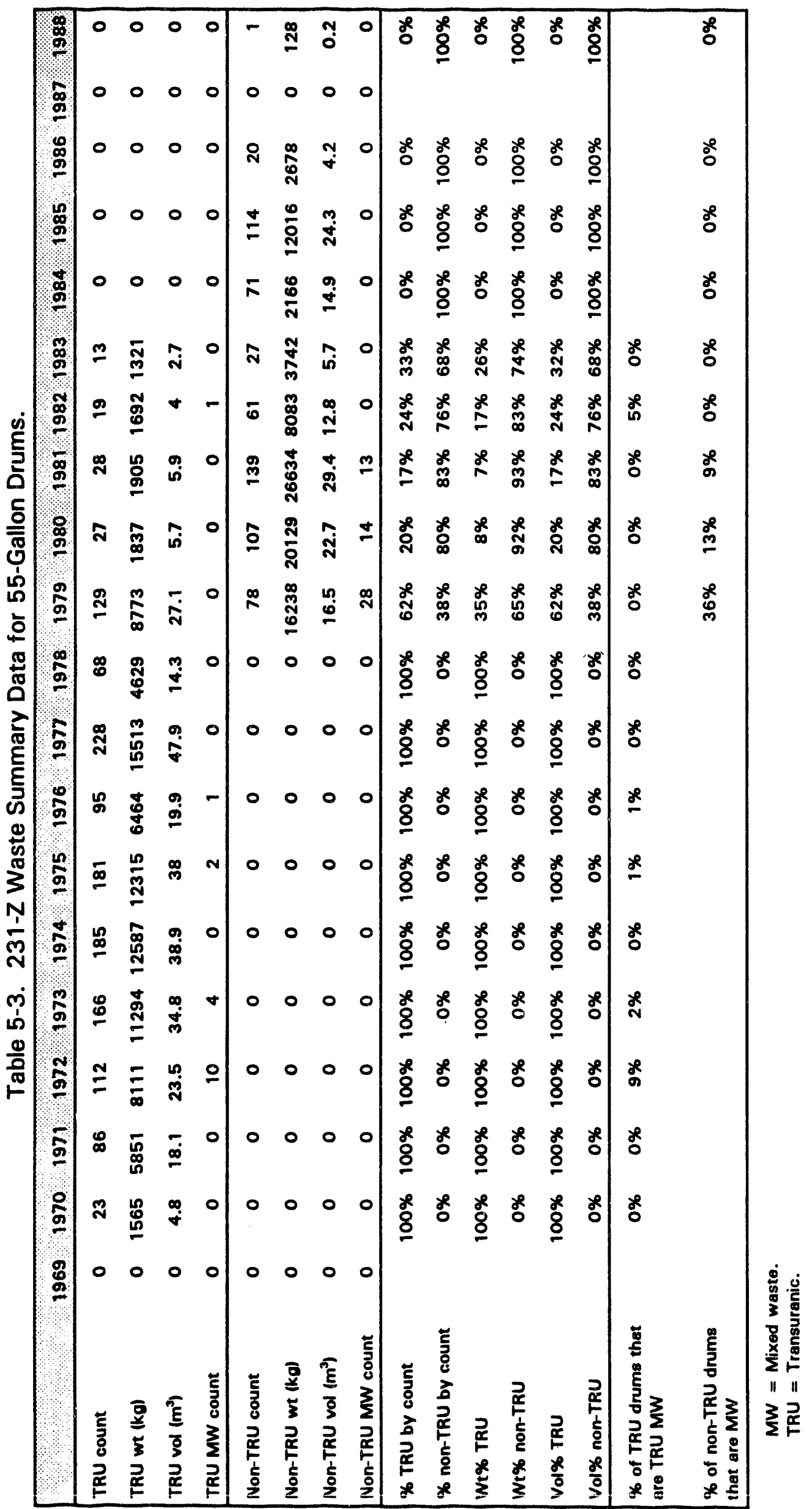




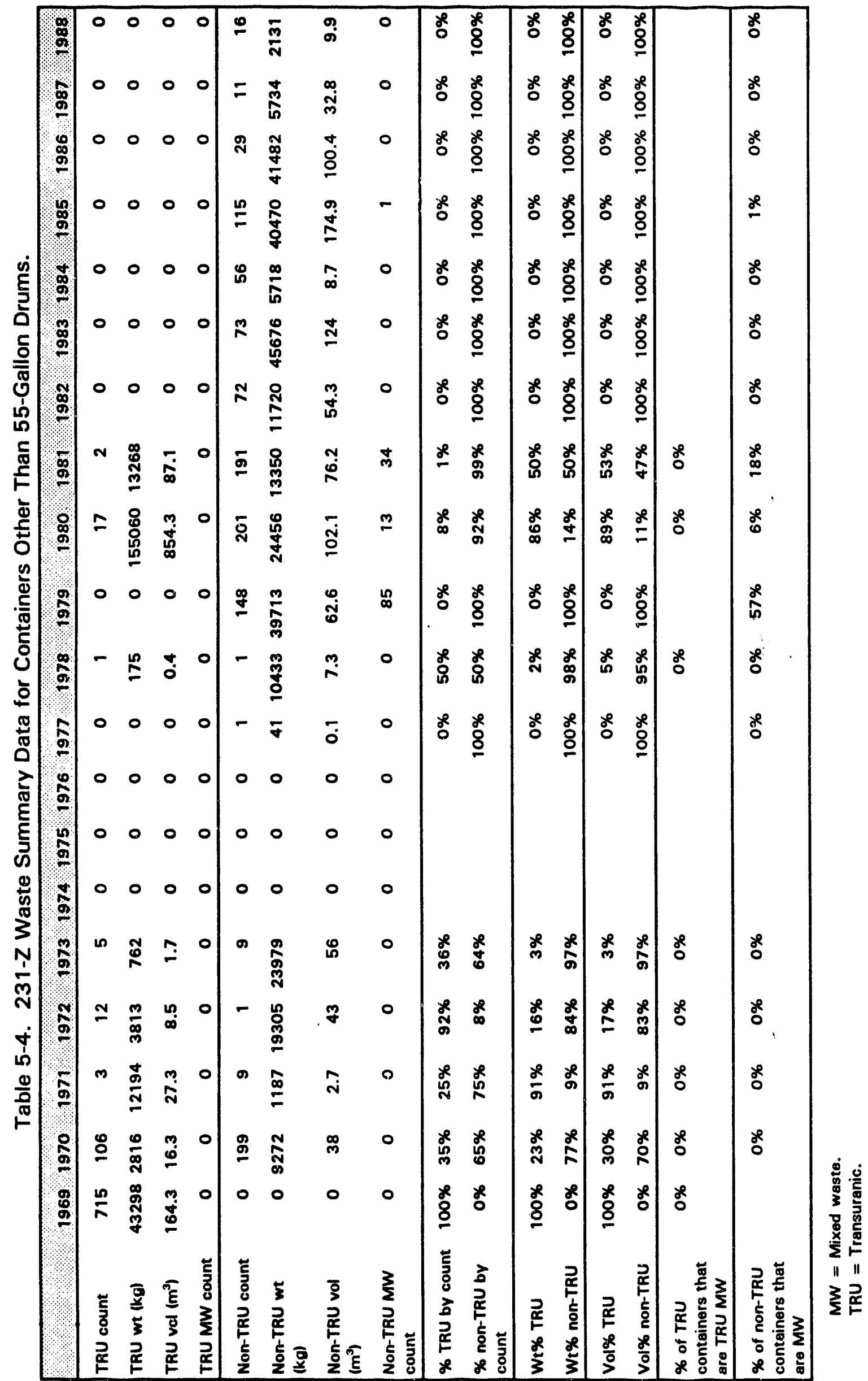


Table 5-5. 231-Z Burial Boxes From 1980 and 1981.

\begin{tabular}{|c|c|c|c|c|c|}
\hline $\begin{array}{c}\text { Container } \\
\text { number }\end{array}$ & $\begin{array}{c}\text { Date } \\
\text { accepted }\end{array}$ & $\begin{array}{c}\text { Storage } \\
\text { location }\end{array}$ & $\begin{array}{c}\text { Container } \\
\text { weight (Ib) }\end{array}$ & $\begin{array}{c}\text { Container } \\
\text { volume (ft }\end{array}$ & $\begin{array}{c}\text { Grams } \\
\text { of TRU } \\
\text { (PU) }\end{array}$ \\
\hline $231-Z-D R-1$ & $11 / 18 / 80$ & $218-W-4 C$ & 22,000 & 2,281 & $53.0 \mathrm{~g}$ \\
\hline $231-Z-D R-2$ & $11 / 19 / 80$ & $218-W-4 C$ & 13,000 & 1,344 & $0.0 \mathrm{~g}$ \\
\hline $231-Z-D R-3$ & $11 / 18 / 80$ & $218-\mathrm{W}-4 \mathrm{C}$ & 20,000 & 2,281 & $200.0 \mathrm{~g}$ \\
\hline $231-Z-D R-4$ & $2 / 9 / 81$ & $218-\mathrm{W}-4 \mathrm{C}$ & $13,00 \mathrm{C}$ & 1,537 & $39.0 \mathrm{~g}$ \\
\hline $231-Z-D R-5$ & $11 / 20 / 80$ & $218-\mathrm{W}-4 \mathrm{C}$ & 22,500 & 2,281 & $30.0 \mathrm{~g}$ \\
\hline $231-Z-D R-6$ & $11 / 19 / 80$ & $218-\mathrm{W}-4 \mathrm{C}$ & 18,000 & 2,281 & $<0.01 \mathrm{~g}$ \\
\hline $231-Z-D R-7$ & $2 / 9 / 81$ & $218-\mathrm{W}-4 \mathrm{C}$ & 12,000 & 1,537 & $5.0 \mathrm{~g}$ \\
\hline $231-Z-D R-8$ & $11 / 19 / 80$ & $218-\mathrm{W}-4 \mathrm{C}$ & 13,000 & 1,344 & $157.0 \mathrm{~g}$ \\
\hline $231-Z-D R-9$ & $11 / 20 / 80$ & $218-\mathrm{W}-4 \mathrm{C}$ & 11,600 & 1,344 & $8.0 \mathrm{~g}$ \\
\hline $231-Z-D R-10$ & $11 / 19 / 80$ & $218-\mathrm{W}-4 \mathrm{C}$ & 12,500 & 1,344 & $<0.01 \mathrm{~g}$ \\
\hline $231-Z-D R-11$ & $11 / 17 / 80$ & $218-\mathrm{W}-4 \mathrm{C}$ & 83,000 & 1,710 & $108.0 \mathrm{~g}$ \\
\hline $231-Z-D R-12$ & $2 / 9 / 81$ & $218-\mathrm{W}-4 \mathrm{C}$ & 15,500 & 1,537 & $30.0 \mathrm{~g}$ \\
\hline $231-Z-D R-13$ & $12 / 2 / 80$ & $218-\mathrm{W}-4 \mathrm{C}$ & 16,000 & 1,537 & $184.0 \mathrm{~g}$ \\
\hline $231-Z-D R-14$ & $2 / 9 / 81$ & $218-\mathrm{W}-4 \mathrm{C}$ & 13,250 & 1,537 & $74.0 \mathrm{~g}$ \\
\hline $231-Z-D R-15$ & $11 / 20 / 80$ & $218-\mathrm{W}-4 \mathrm{C}$ & 16,500 & 2,281 & $108.0 \mathrm{~g}$ \\
\hline $231-Z-D R-16$ & $11 / 19 / 80$ & $218-\mathrm{W}-4 \mathrm{C}$ & 12,250 & 1,152 & $<0.01 \mathrm{~g}$ \\
\hline $231-Z-D R-17$ & $11 / 20 / 80$ & $218-\mathrm{W}-4 \mathrm{C}$ & 23,000 & 2,281 & $1.0 \mathrm{~g}$ \\
\hline $231-Z-D R-19$ & $11 / 19 / 80$ & $218-\mathrm{W}-4 \mathrm{C}$ & 23,000 & 2,281 & $17.0 \mathrm{~g}$ \\
\hline $231-Z-D R-20$ & $11 / 18 / 80$ & $218-\mathrm{W}-4 \mathrm{C}$ & 8,000 & 1,368 & $14.0 \mathrm{~g}$ \\
\hline
\end{tabular}

TRU = Transuranic. 

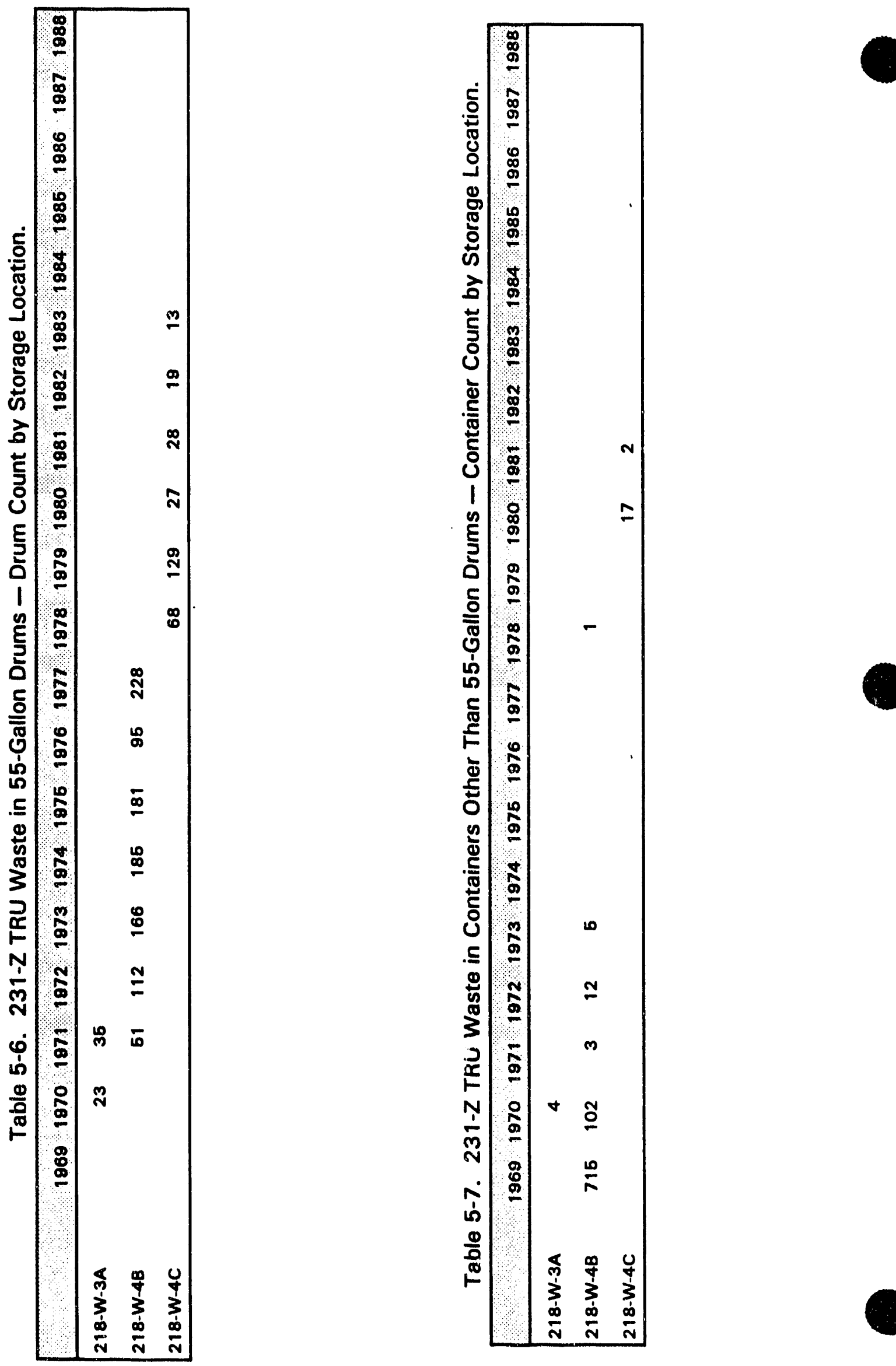

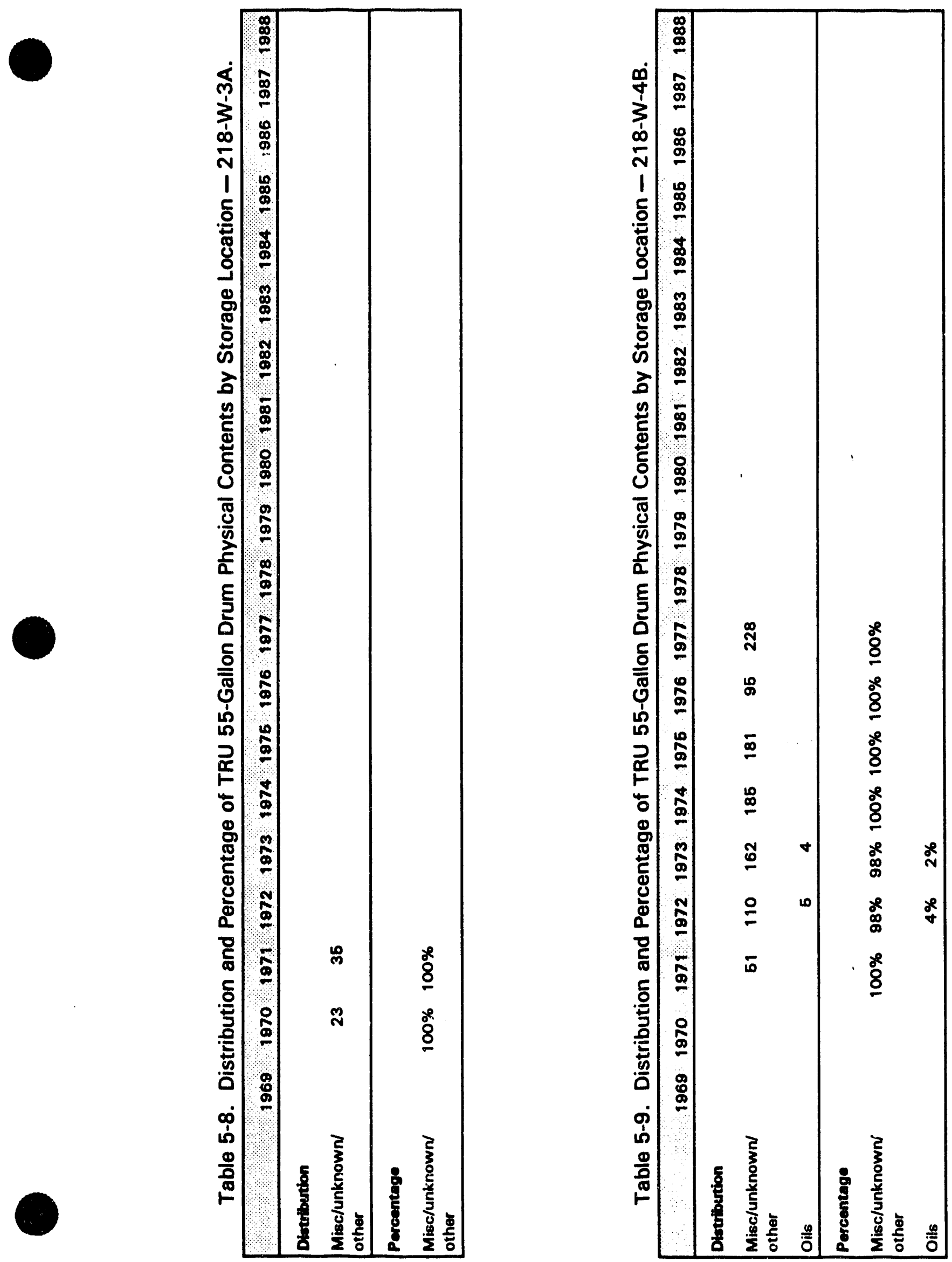
WHC-EP-0659

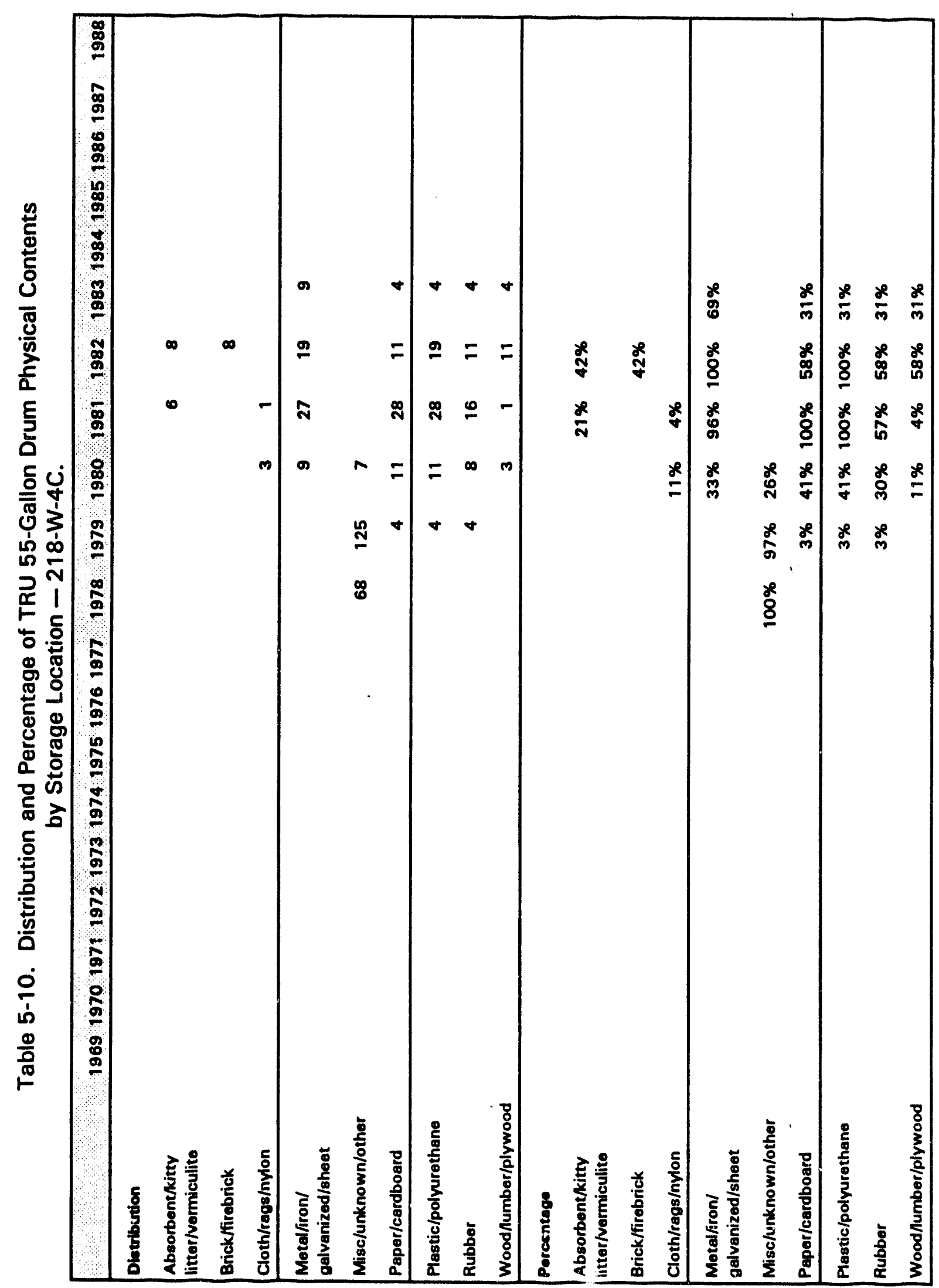


WHC-EP-0659
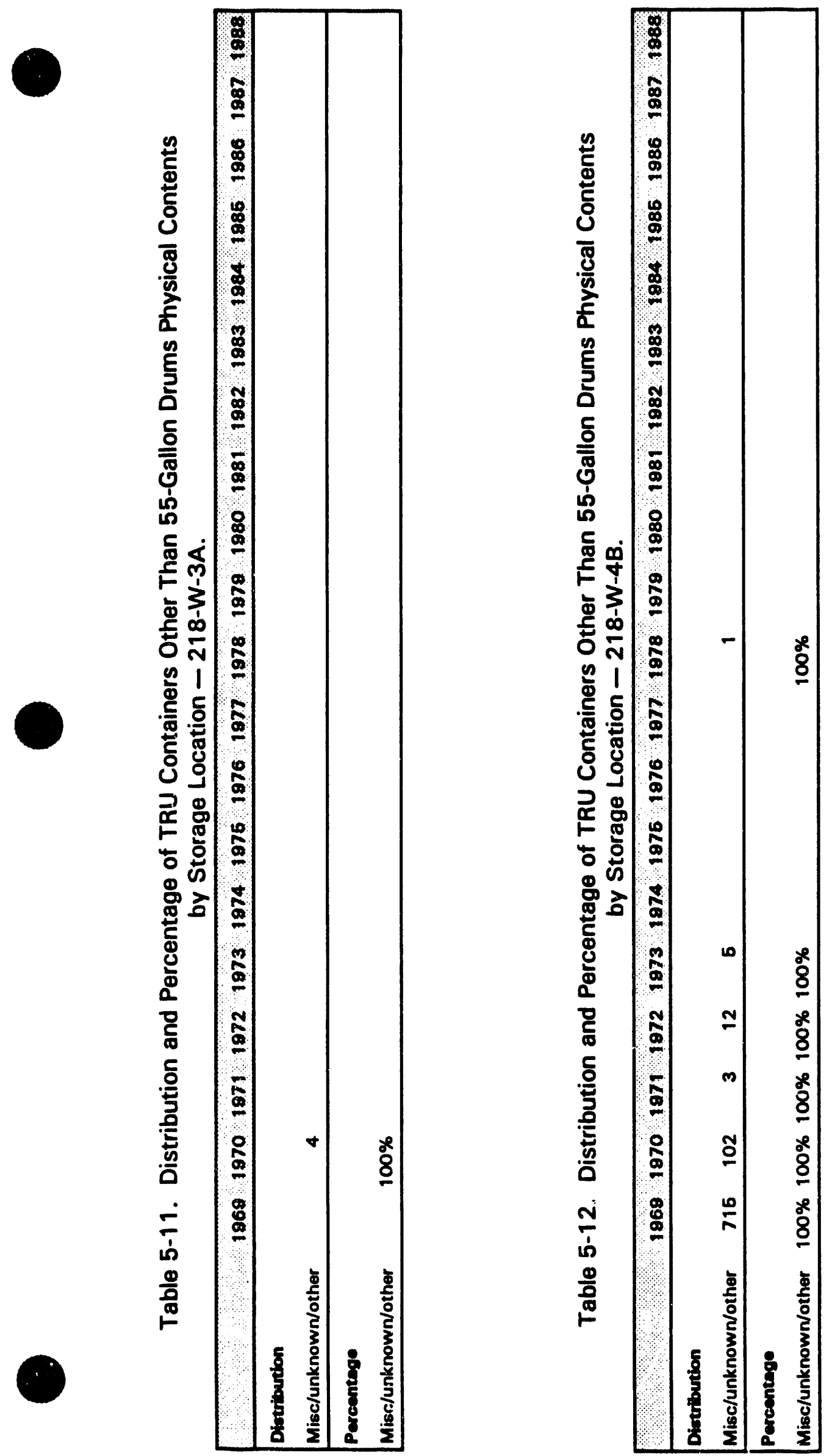

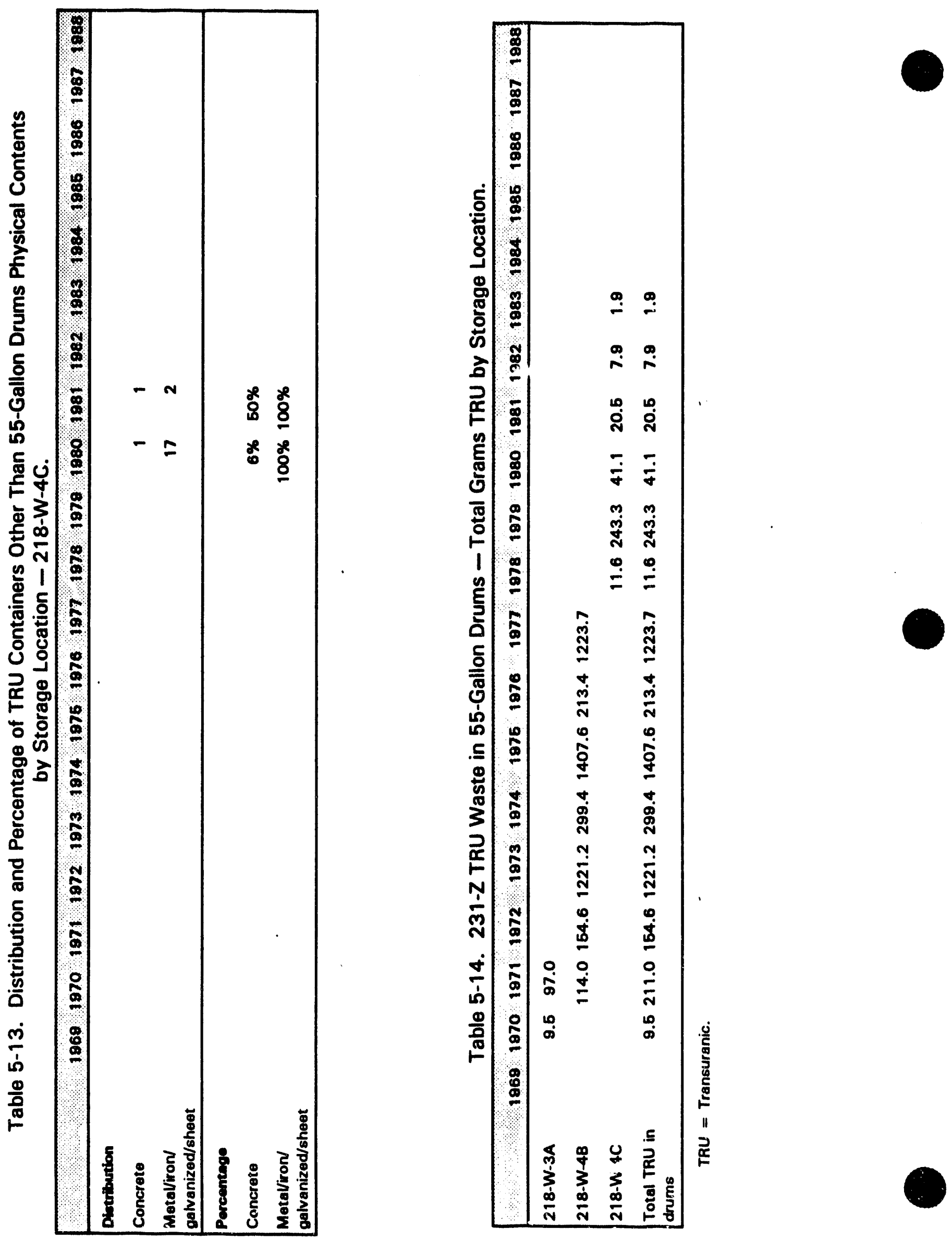
WHC-EP-0659
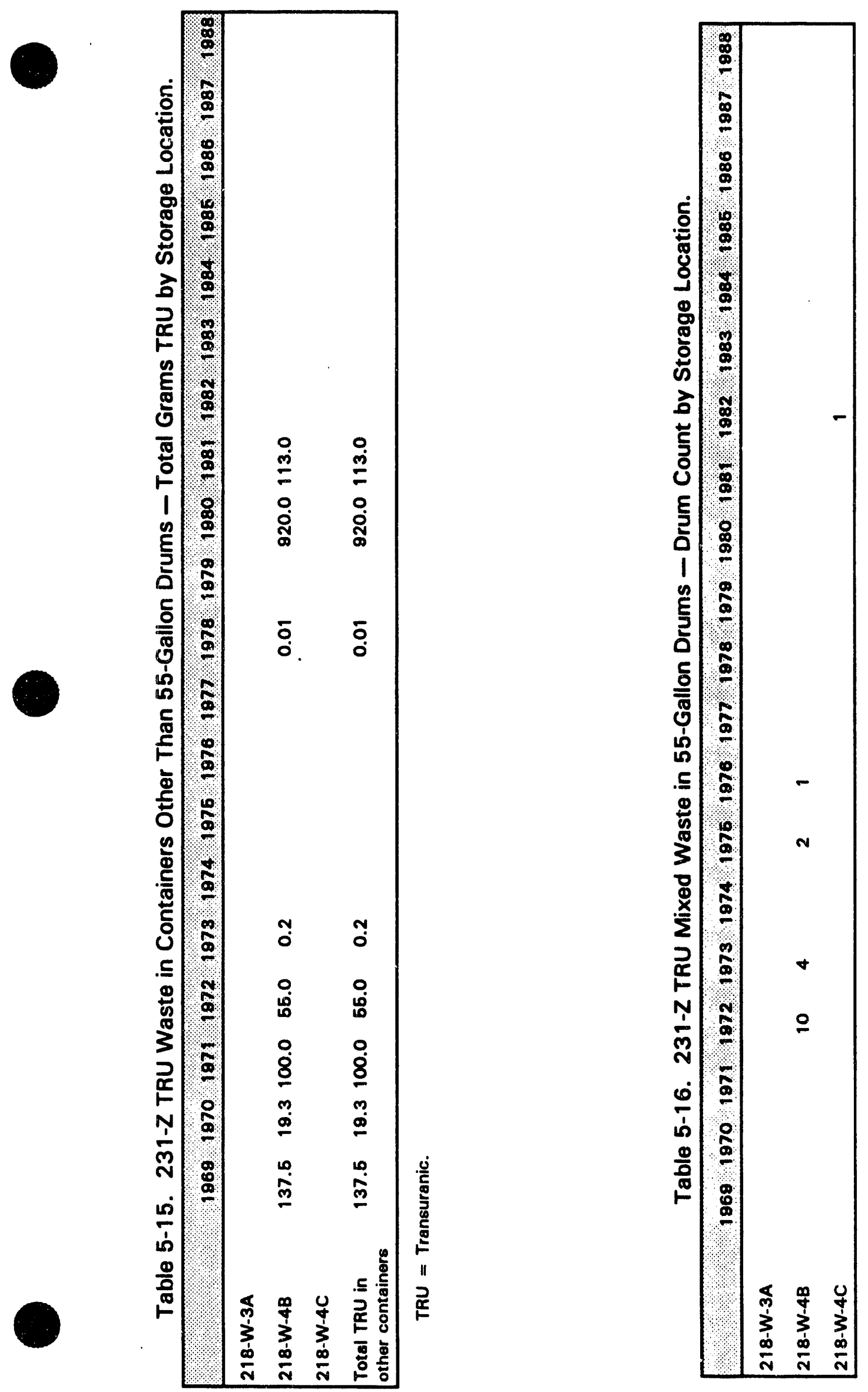

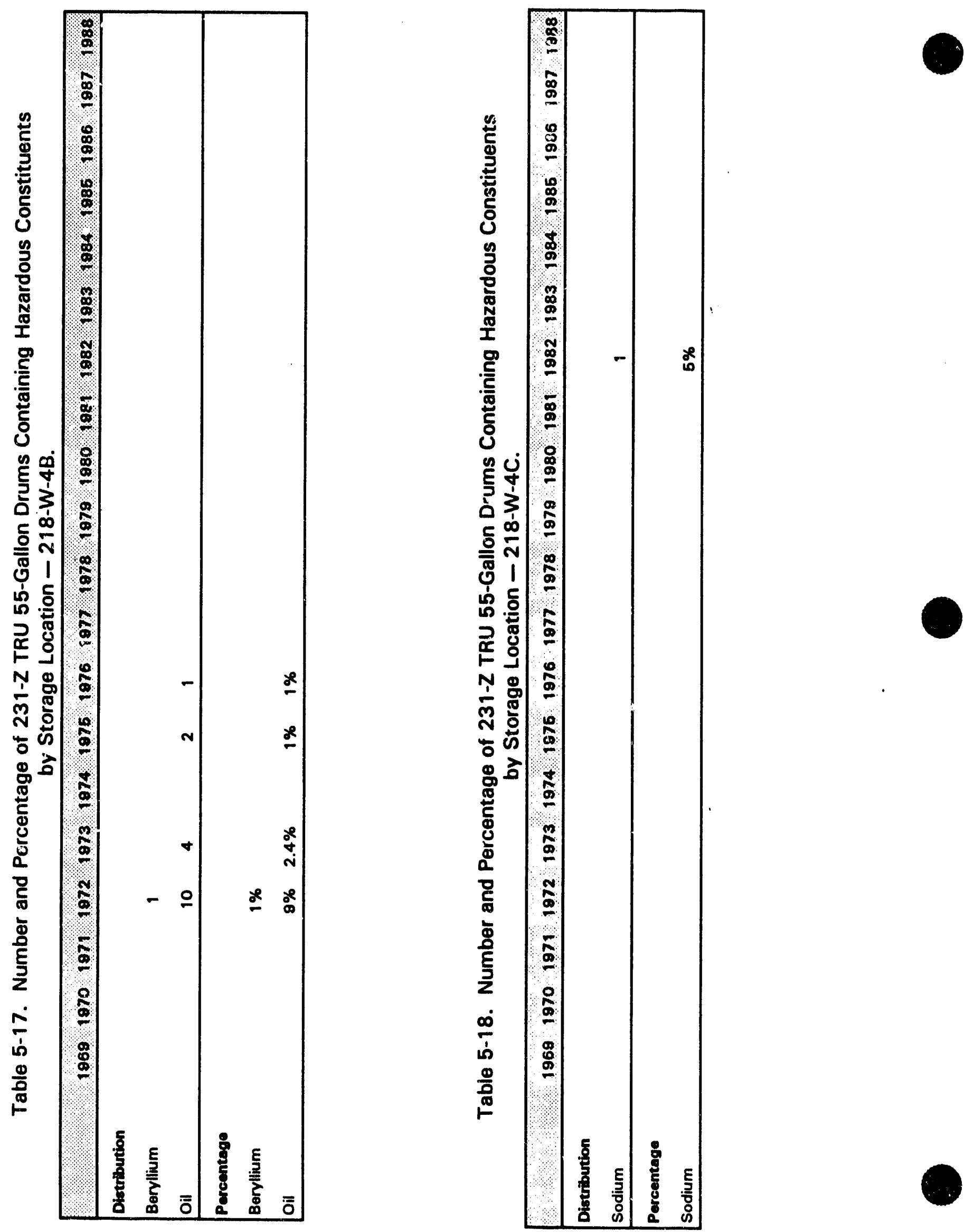
Table 5-19. Hazardous Substances Known or Suspected to be in the 231-Z Solid Waste System. (3 sheets)

\begin{tabular}{|c|c|c|c|c|}
\hline $\begin{array}{c}\text { Compound } \\
\text { name }\end{array}$ & Chemical formula & $\begin{array}{c}\text { Information } \\
\text { source }\end{array}$ & $\begin{array}{c}\text { EPA } \\
\text { toxicity } \\
\text { category }\end{array}$ & $\begin{array}{c}\text { DOT } \\
\text { classification }\end{array}$ \\
\hline Acetone & $\mathrm{CH}_{3} \mathrm{COCH}_{3}$ & 5,6 & $D$ & Flammable liquid \\
\hline Alcohol & $\mathrm{C}_{2} \mathrm{H}_{5} \mathrm{OH}$ & 1,5 & & Flammable liquid \\
\hline Asbestos & Fibrous mineral silicates & 5 & $x$ & ORM-C \\
\hline Benzene & $\mathrm{C}_{8} \mathrm{H}_{6}$ & 1 & A & Flammable liquid \\
\hline Berkelium $^{b}$ & Bk & 4 & & \\
\hline Beryllium & $\mathrm{Be}$ & $2,3,4,5,6$ & $x$ & Poison B \\
\hline Cadmium & $\mathrm{Cd}$ & 3 & A & \\
\hline $\begin{array}{l}\text { Carbon } \\
\text { tetrachloride }\end{array}$ & $\mathrm{CCl}_{4}$ & 1 & A & ORM-A \\
\hline Cellulose acetate & Partially acetylated cellulose & 1 & & \\
\hline Copper salts & & 5 & $D$ & \\
\hline Cyanide salts & $\mathrm{CN}$ & 5,6 & A & Poison B \\
\hline Freon-113 & $\mathrm{CCl}_{2} \mathrm{FCClF}_{2}$ & 1 & B & \\
\hline Graphite & C & 1 & & \\
\hline Hydraulic fluid & Various hydrocarbons & 1 & B & \\
\hline Hydrochloric acid & $\mathrm{HCl}$ & 1 & $D$ & $\begin{array}{l}\text { Nonflammable gas, } \\
\text { corrosive }\end{array}$ \\
\hline Hydrogen peroxide & $\mathrm{H}_{2} \mathrm{O}_{2}$ & 3 & B & Oxidizer \\
\hline Lard oil & & 5 & & \\
\hline Lead & $\mathrm{Pb}$ & 4 & $x$ & \\
\hline Magnesium oxide & $\mathrm{MgO}$ & 1,5 & & \\
\hline Mercury & $\mathrm{Hg}$ & 4,5 & $x$ & ORM-B \\
\hline Methylene chloride & $\mathrm{CH}_{2} \mathrm{Cl}_{2}$ & 5 & C & ORM-A \\
\hline Molybdenum & Mo & 5 & & \\
\hline Nickel salts & & 5 & B & \\
\hline Nitric acid & $\mathrm{HNO}_{3}$ & 5 & C & Oxidizer, corrosive \\
\hline Oil & Various hydrocarbons & 1,2 & & \\
\hline Oil, vacuum pump & Various hydrocarbons & 1,4 & & \\
\hline PCBs & Polychlorinated biphenyls & 5 & $x$ & \\
\hline
\end{tabular}


Table 5-19. Hazardous Substances Known or Suspected to be in the 231-Z Solid Waste System. (3 sheets)

\begin{tabular}{|c|c|c|c|c|}
\hline $\begin{array}{l}\text { Compound } \\
\text { name }\end{array}$ & Chemical formula & $\begin{array}{l}\text { Information } \\
\text { source }\end{array}$ & $\begin{array}{c}\text { EPA } \\
\text { toxicity } \\
\text { category }\end{array}$ & $\begin{array}{l}\text { DOT } \\
\text { classification }\end{array}$ \\
\hline Phosphoric acid & $\mathrm{H}_{3} \mathrm{PO}_{4}$ & 4,5 & D & Corrosive \\
\hline Plutonium nitrite & & 5 & & \\
\hline $\begin{array}{l}\text { Plutonium oxide - } \\
\text { sugar mixture }\end{array}$ & $\mathrm{PuO}_{2}$ - sugar & 1 & & \\
\hline Polypropylene & $\mathrm{C}_{3} \mathrm{H}_{6}$ & 5 & & \\
\hline Polystyrene & $\mathrm{C}_{\mathrm{g}} \mathrm{H}_{\mathrm{e}}$ & 1,5 & & \\
\hline Portland cement & & 5 & & \\
\hline Propane & $\mathrm{CH}_{3} \mathrm{CH}_{2} \mathrm{CH}_{3}$ & 3,5 & $x$ & Flammable gas \\
\hline Sodium phosphate & $\mathrm{H}_{x} \mathrm{Na}_{x} \mathrm{O}_{4} \mathrm{P}$ & 4 & D & \\
\hline Sodium & $\mathrm{Na}$ & 2.3 & A & $\begin{array}{l}\text { Flammable solid, } \\
\text { dangerous when wet }\end{array}$ \\
\hline Sodium hydroxide & $\mathrm{NaOH}$ & $3,4,5$ & C & Corrosive \\
\hline Sulfamic acid & $\mathrm{H}_{3} \mathrm{NO}_{3} \mathrm{~S}$ & 1 & D & \\
\hline Sulfate salts & & 1,5 & & \\
\hline Tantalum & $T_{i}$ & 1,5 & & \\
\hline Teflon & $\mathrm{CF}_{2}$ chains & 1 & & \\
\hline Trichloroethane & $\mathrm{C}_{2} \mathrm{H}_{3} \mathrm{Cl}_{3}$ & 5 & B & ORM-A \\
\hline Trichloroethylene & $\mathrm{C}_{2} \mathrm{H} \mathrm{Cl}_{3}$ & 5 & B & ORM-A \\
\hline Tungsten & W & 5 & & \\
\hline Uranyl nitrate & $\mathrm{N}_{2} \mathrm{O}_{8} \mathrm{U}$ & 5 & $\mathbf{B}$ & Radioactive material \\
\hline
\end{tabular}


Table 5-19. Hazardous Substances Known or Suspected to be in the 231-Z Solid Waste System. (3 sheets)

\begin{tabular}{|c|c|c|c|c|}
\hline $\begin{array}{l}\text { Compound } \\
\text { name }\end{array}$ & Chemical formula & $\begin{array}{l}\text { Information } \\
\text { source" }\end{array}$ & $\begin{array}{l}\text { EPA } \\
\text { toxicity } \\
\text { category }\end{array}$ & $\begin{array}{l}\text { DOT } \\
\text { classification }\end{array}$ \\
\hline $\begin{array}{l}\text { Uranyl nitrate } \\
\text { hexahydrate }\end{array}$ & $\mathrm{N}_{2} \mathrm{O}_{8} \mathrm{U} \cdot 6 \mathrm{H}_{2} \mathrm{O}$ & 3 & B & Radioactive material \\
\hline Zirconium & $\mathrm{Zr}$ & 5,6 & & $\begin{array}{l}\text { Flammable solid, } \\
\text { flammable liquid }\end{array}$ \\
\hline
\end{tabular}

"Source number refers to the following:

1. BNWL-CC-1924, Safety Analysis Report, 231-Z Building (BNWL 1970)

2. Solid Waste Information Tracking System (SWITS)

3. WHC-SD-WM-RPT-056, Solid Waste Stream Hazardous and Dangerous Components Study (WHC 1992)

4. Solid Waste Burial Records (SWBR)

5. Personnel interviews

6. WHC-EP-0603, Reactive and Unstable Chemicals in Transuranic Retrievable Waste at the Hanford Site (Reddinger 1992).

berkelium has been determined to have been entered on the Solid Waste Burial Record in error.

'Tefion is a trademark of duPont de Nemours and Company.

DOT = U.S. Department of Transportation.

EPA $=$ U.S. Environmental Protection Agency.

ORM = Other radioactive material. 
Table 5-20. Summary of Information from Solid Waste Storage Disposal Records for TRU Wastes with Hazardous Contents from PNL 231-Z.

\begin{tabular}{|c|c|c|c|c|c|c|}
\hline $\begin{array}{l}\text { Date } \\
\text { accepted }\end{array}$ & PIN & $\begin{array}{l}\text { Burial record } \\
\text { number }\end{array}$ & $\begin{array}{l}\text { Hazardous } \\
\text { constituents }\end{array}$ & $\begin{array}{l}\text { Waste } \\
\text { Codes }\end{array}$ & $\begin{array}{l}\text { Weight } \\
\text { (kg) }\end{array}$ & $\begin{array}{c}\text { Volume } \\
(\%)\end{array}$ \\
\hline $04 / 28 / 72$ & & 231-Z-BA-28-72-018 & Beryllium mercury & & & \\
\hline $06 / 02 / 72$ & & 231-Z-BR-6-2-72-024 & Beryllium & & & \\
\hline $12 / 01 / 72$ & $11-72 * 6$ & BNW-231-Z-72-076 & Beryllium & & & \\
\hline $02 / 27 / 73$ & $2-73-14$ & 231-Z-BNW-73-031 & Sodium hydroxide & & & \\
\hline $03 / 23 / 79$ & $231-z-14$ & 231-Z-PNL-79-3 & Phosphoric acid & & & \\
\hline $05 / 18 / 79$ & $4-78-26$ & 231-Z-PNL-79-40 & Phosphoric acid & & & \\
\hline $05 / 18 / 79$ & $4-78-27$ & 231-Z-PNL-79-41 & Phosphoric acid & & & \\
\hline $05 / 18,79$ & $4-78-28$ & 231-Z-PNL-79-42 & Phosphoric acid & & & \\
\hline $05 / 18 / 79$ & $4-78-29$ & 231-Z-PNL-79-43 & Phosphoric acid & & & \\
\hline $05 / 18 / 79$ & 4-78-30 & $231-Z-P N L-79-44$ & Phosphoric acid & & & \\
\hline $05 / 18 / 79$ & $4-78-31$ & 231-Z-PNL-79-45 & Phosphoric acid & & & \\
\hline $05 / 18 / 79$ & 4-78-32 & 231-Z-PNL-79-46 & Phosphoric acid & & & \\
\hline $06 / 01 / 79$ & $231-2-17$ & 231-Z-PNL-79-6 & Phosphoric acid & & & \\
\hline $02 / 18 / 81$ & PNL-2-18-81 & 231-Z-PNL-81-6 & Lead (pigs) & D008 & & 11 \\
\hline $04 / 16 / 82$ & $231-z-81-2$ & 231-Z-PNL-82-1 & Sodium phosphate & & & $3 \cdot$ \\
\hline $04 / 16 / 82$ & $231-z-81-2$ & 231-Z-PNL-82-1 & Sodium phosphate & & & $3 \bullet$ \\
\hline $04 / 16 / 82$ & $231-z-81-2$ & 231-Z-PNL-82-1 & Sodium phosphate & & & $3^{\circ}$ \\
\hline $04 / 16 / 82$ & $231-z-81-2$ & 231-Z-PNL-82-1 & Sodium phosphate & & & $3 \bullet$ \\
\hline $04 / 16 / 82$ & $231-z-81-2$ & 231-Z-PNL-82-1 & Sodium phosphate & & & $3^{*}$ \\
\hline $04 / 16 / 82$ & $231-z-31-2$ & 231-Z-PNL-82-1 & Sodium phosphate & & & $3 \cdot$ \\
\hline $04 / 16 / 82$ & $231-Z-81-2$ & 231-Z-PNL-82-1 & Sodium phosphate & & & $3 *$ \\
\hline $04 / 16 / 82$ & $231-2-81-2$ & 231-Z-PNL-82-1 & Sodium phosphate & & & $3 *$ \\
\hline $07 / 31 / 85$ & PNL-85-161 & 231-Z-PNL-85-2 & Lead (sheet) & D008 & 455 & 2 \\
\hline
\end{tabular}

PIN = Personal identification number.

- Volume percents represent entire shipment, rather than individual containers. 
Table 5-21. Summary of Information from Solid Waste Storage Disposal Records for Low-Level Waste with Hazardous Contents from PNL 231-Z.

\begin{tabular}{|c|c|c|c|c|c|c|}
\hline $\begin{array}{l}\text { Date } \\
\text { accepted }\end{array}$ & PIN & $\begin{array}{l}\text { Burial record } \\
\text { number }\end{array}$ & $\begin{array}{l}\text { Hazardous } \\
\text { constituents }\end{array}$ & $\begin{array}{l}\text { Waste } \\
\text { codes }\end{array}$ & $\begin{array}{l}\text { Weight } \\
\text { (kol }\end{array}$ & $\begin{array}{l}\text { Volume } \\
(\%)\end{array}$ \\
\hline $10 / 05 / 79$ & $231-z-28$ & 231-Z-PNL-79-14 & Phosphoric acid & & & 95 \\
\hline $11 / 27 / 79$ & $231-z-35$ & 231-Z-PNL-79-17 & Phosphoric acid & & & \\
\hline $03 / 04 / 80$ & $231-z-46$ & 231-Z-PNL-80-8 & Phosphoric acid & & & 80 \\
\hline $05 / 21 / 81$ & $231-z-78$ & 231-Z-PNL-81-14 & Sodium phosphate & & & 100 \\
\hline $06 / 30 / 81$ & $231-2-79$ & 231-Z-PNL-81-15 & Sodium hydroxide & & & 50 \\
\hline
\end{tabular}

PIN = Personal identification number. 
This page intentionally left blank. 


\subsection{REFERENCES}

40 CFR 265, 1991, "Interim Status Standards for Owners and Operators of Hazardous Waste Treatment, Storage, and Disposal Facilities," Code of Federal Regulations, as amended.

40 CFR 302.4, 1989, "Spill Table," Code of Federal Regulations, as amended.

49 CFR 100-199, 1989, "Transportation," Code of Federal Regulations, as amended.

AEC, 1970, Immediate Action Directive 0511-21, U.S. Atomic Energy Commission, Washington, D.C.

AEC, 1973, Atomic Energy Commission Manual, Chapter 0511, "Radioactive Waste Management," U.S. Atomic Energy Commission, Washington, D.C.

Anderson, B. C., J. D. Anderson, J. A. Demiter, D. R. Duncan, L. A. Fort, D. C. McCann, and S. J. Stone, 1991, Contact-Handled Transuranic Waste Characterization Based on Existing Records, WHC-EP-0225, Revision 1, Westinghouse Hanford Company, Richland, Washington.

ARH, 1974, Specifications and Standards for Packaging, Storage, and Disposal of Richland Operations Solid Wastes, as amended, ARH-3032, Atlantic Richfield Hanford, Richland, Washington.

BNWL, 1970, Safety Analysis Report 231-Z Building, BNWL-CC-1924, Supplements 1 and 4, Battelle Northwest Laboratory, Richland, Washington.

BNWL, 1976, Detailed Plan for the Decontamination and Restoration of the 231-Z Facility, BNWL-B-479/UC-70, Battelle Northwest Laboratory, Richland, Washington.

DOE, 1982, Management of Transuranic Material, DOE Order 5820.1, U.S. Department of Energy, Washington, D.C.

Duncan, D. R., D. A. Burbank, B. C. Anderson, and J. A. Demiter, 1992, Application of Service Examinations to Transuranic Waste Container Integrity at the Hanford Site, WHC-SA-1450-FP, Westinghouse Hanford Company, Richland, Washington.

Resource Conservation and Recovery Act of 1976, Public Law 94-580, 90 Stat. 2003. 42 USC 6901 et seq.

Reddinger, R. W., 1992, Reactive and Unstable Chemicals in Transuranic Retrievable Waste at the Hanford Site - A Review of Available Data, WHC-EP-0603, Westinghouse Hanford Company, Richland, Washington.

RHO, 1980, Hanford Radioactive Solid Waste Packaging, Storage, and Disposal Requirements, as amended, RHO-MA-222, Rockwell Hanford Operations, Richland, Washington. 
RHO, 1985, 200 Areas Fact Book, Rockwell Hanford Operations, Richland, Washington.

WAC 173-303, 1989, "Dangerous Waste Regulations," Washington Administrative Code, as amended.

WHC, 1992, Solid Waste Stream Hazardous and Dangerous Components Study, WHC-SP-WM-RPT-056, Westinghouse Hanford Company, Richland, Washington.

Willis, N. P. and G. C. Triner, 1991. Hanford Site Radioactive Solid Waste Acceptance Criteria, WHC-EP-0063-3, Westinghouse Hanford Company, Richland, Washington. 
WHC-EP-0659

\section{APPENDIX A}

DATA ON 231-Z WASTE GENERATION FROM THE SOLID WASTE INFORMATION TRACKING SYSTEM 
WHC-EP-0659

This page intentionally left blank. 


\section{DATA ON 231-Z WASTE GENERATION FROM THE SOLID WASTE INFORMATION TRACKING SYSTEM}

The information found in this appendix is from the Solid Waste Information and Tracking System (SWITS) database. This database incorporates the older Richland Solid Waste Information Management System (R-SWIMS) database and is used to track information on radioactive and other wastes stored or disposed of at the Hanford Site.

Each SWITS data run in this appendix is preceded by the query used to generate the data. A brief explanation of the run and any additional information needed to uncerstand the da: $A$ presented is also included.

The bulk of the data provided is limited to information about transuranic (TRU) waste generated at Plutonium Metallurgy Laboratory (231-Z); however, some general information on non-TRU waste is included for completeness. The term non-TRU is used, instead of low-level waste (LLW), because a small percentage of the waste has been designated orily as not TRU. It is believed that most, if not all, of the non-TRU waste is LLW.

The data runs in this appendix are further segregated by waste container type. Since initial retrieval efforts and the Waste Retrieval and Processing Plant (WRAP) 1 will focus on 55-gal drums, these container types are considered separately.

Some general information about the SWITS database and the codes used follows. Please note the disclaimer found on the next page. 


\section{WHC-EP-0659}

DON'T SAY IT -- Write It!

Date:

To:

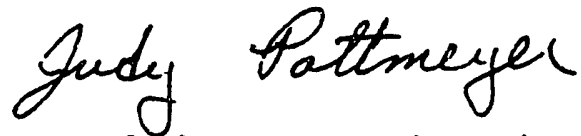

From: Solid Waste Engineering Data Management Group

N3-11 6-4394/6-4020

Re: SWITS DATA REQUEST

Attached for your information and use is the data which you requested. This data represents best available information regarding wastes currently in storage at the Hanford site. I trust the information will be suitable to your needs.

Requests for information from the solid Waste Information and Tracking system (SWITS) are normally relatively limited in scope, requesting specific data fields or summary data. The responses to these requests undergo review during data collection, summary and response preparation.

The response to this request represents a simple reproduction of the sWITS Database. Transmittal of this information is made with the following disclaimers:

1) The information contained in this transmittal is raw data, and represents information provided to Solid Waste Engineering (SWE) on burial records or other documents. This data has not been validated.

2) The information contained in this transmittal is subject to change without notice. Continual update of swITs information and improvement of the software system make it impossible to ensure consistency of this data with the database after transmittal.

3) This information is current as of $12 / 11 / 22$.

If I can be of further assistance to you, do not hesitate to call me. 
WHC-EP-0659

\begin{tabular}{|c|c|c|c|}
\hline SWIR401 & Solid Waste Information and Tracking System & $\begin{array}{l}05 / 01 / \\
13: 2.5 \\
\text { Pagge: }\end{array}$ & $\begin{array}{l}92 \\
1\end{array}$ \\
\hline $\begin{array}{l}\text { Primary Waste } \\
\text { Type Code }\end{array}$ & Primary Waste Type Description & $\begin{array}{l}\text { Ship } \\
\text { Iime }\end{array}$ & Rad \\
\hline $\begin{array}{l}\text { AH } \\
\mathbf{C H} \\
\mathbf{H} \\
\mathbf{H P} \\
\mathbf{M} \\
\mathbf{M P} \\
\mathbf{N} \\
\mathbf{P} \\
\mathbf{R} \\
\mathbf{R P} \\
\mathbf{U}\end{array}$ & $\begin{array}{l}\text { HAZ, ADMIN HOLD } \\
\text { MORATORIUN CONTROITD } \\
\text { HAZA DOUS } \\
\text { HAZARDOUS WASTE PCB } \\
\text { MIXED } \\
\text { MIXED PCB } \\
\text { NON-REGUIATED } \\
\text { PCB } \\
\text { RADIOACTIVE } \\
\text { RADIOACTIVE PCB } \\
\text { UNKNOWN }\end{array}$ & $\begin{array}{l}89 \\
89 \\
89 \\
29 \\
89 \\
29 \\
29\end{array}$ & $\begin{array}{l}\mathbf{N} \\
\mathbf{N} \\
\mathbf{N} \\
\mathbf{N} \\
\mathbf{Y} \\
\mathbf{Y} \\
\mathbf{N} \\
\mathbf{N} \\
\mathbf{Y} \\
\mathbf{Y} \\
\mathbf{N}\end{array}$ \\
\hline
\end{tabular}




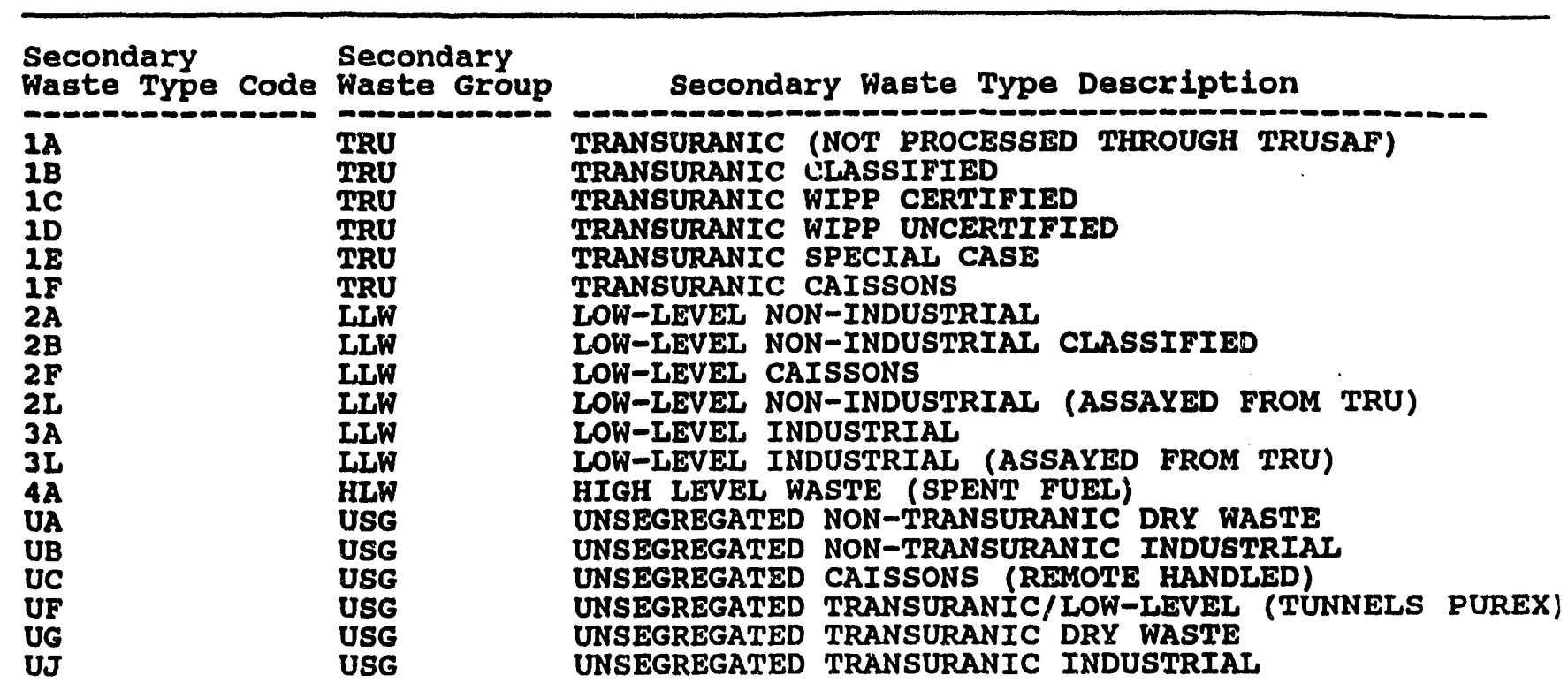


WHC-EP-0659

APPENDIX A. 1

CONTAINER NUMBER AND WEIGHT OF TRU WASTE IN 55-GALLON DRUMS BY WASTE TYPE 
WHC-EP-0659

This page intentionally left blank.

A-8 


\section{CONTAINER NUMBER AND WEIGHT OF TRU WASTE IN 55-GALLON DRUMS BY WASTE TYPE}

This data run gives an overall look at the waste types, container numbers, and total weight (in kilograms) of the radioactive wastes generated at Plutonium Metallurgy Laboratory $(231-\mathrm{Z})$ on a yearly basis. These data are for wastes stored in 55-gal drums only. The meanings of primary and secondary waste codes can be found in the introductory materials for this appendix.

The data in the average weight column should be taken cautiously, especially for LLW codes. Concern is warranted because LLW records are still done on a batch basis. This means that one weight datum may be the composite weight for a group of drums. The computer program used simply divided the sum of all weight values by the number of values used to compute the total weight, not the actual number of containers that value represents.

From 1970 until 1978 individual container weights were not required for TRU waste drums. During the data re-entry prosnram in the mid-1980's standard weights were assigned for all container types; 55-gal drums were given a standard weight of $68 \mathrm{~kg}$ $(149.9 \mathrm{lb})$. This is why the average weight per drum for TRU is so consistent during this period. 


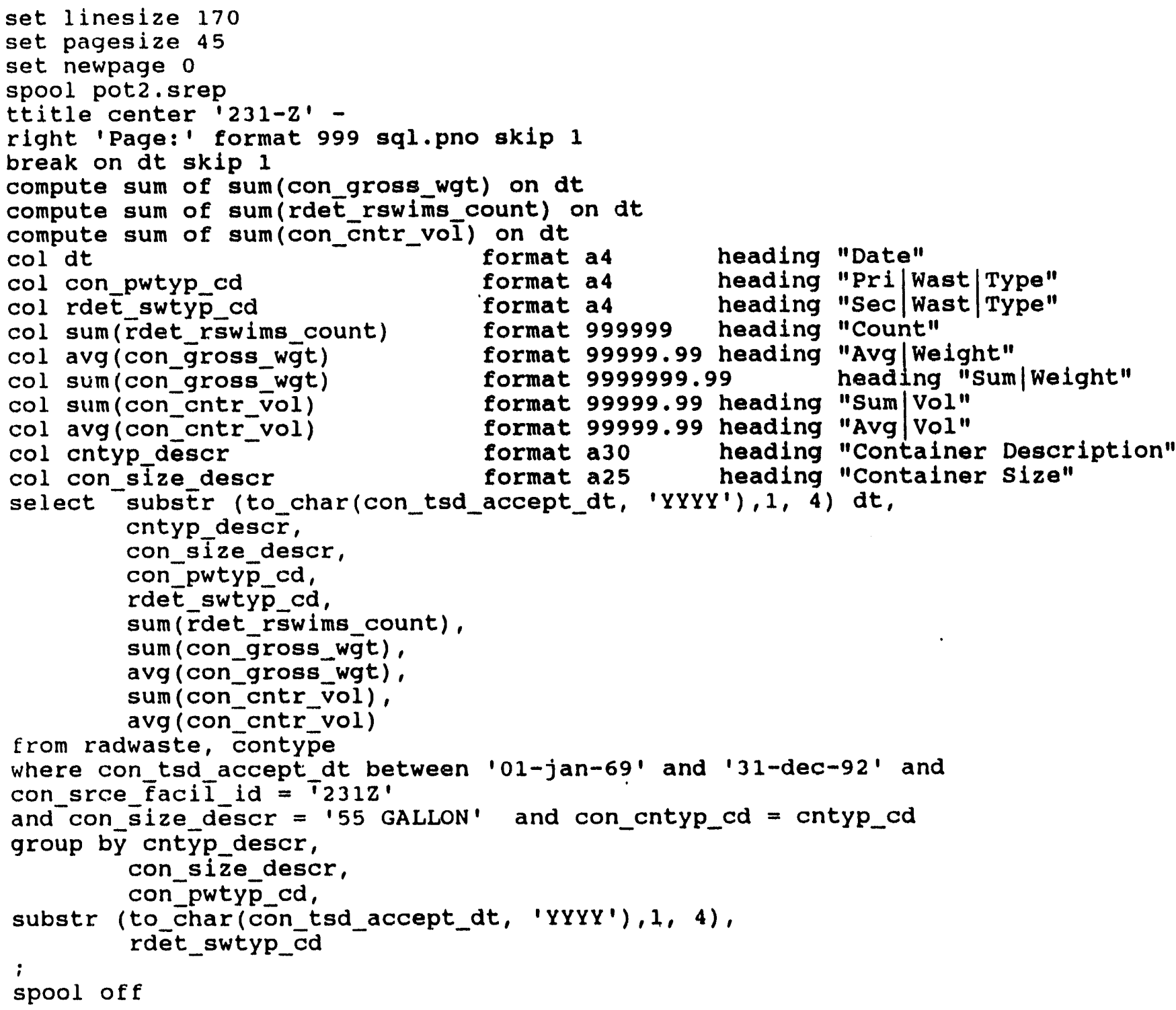


WHC-EP-0659

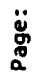

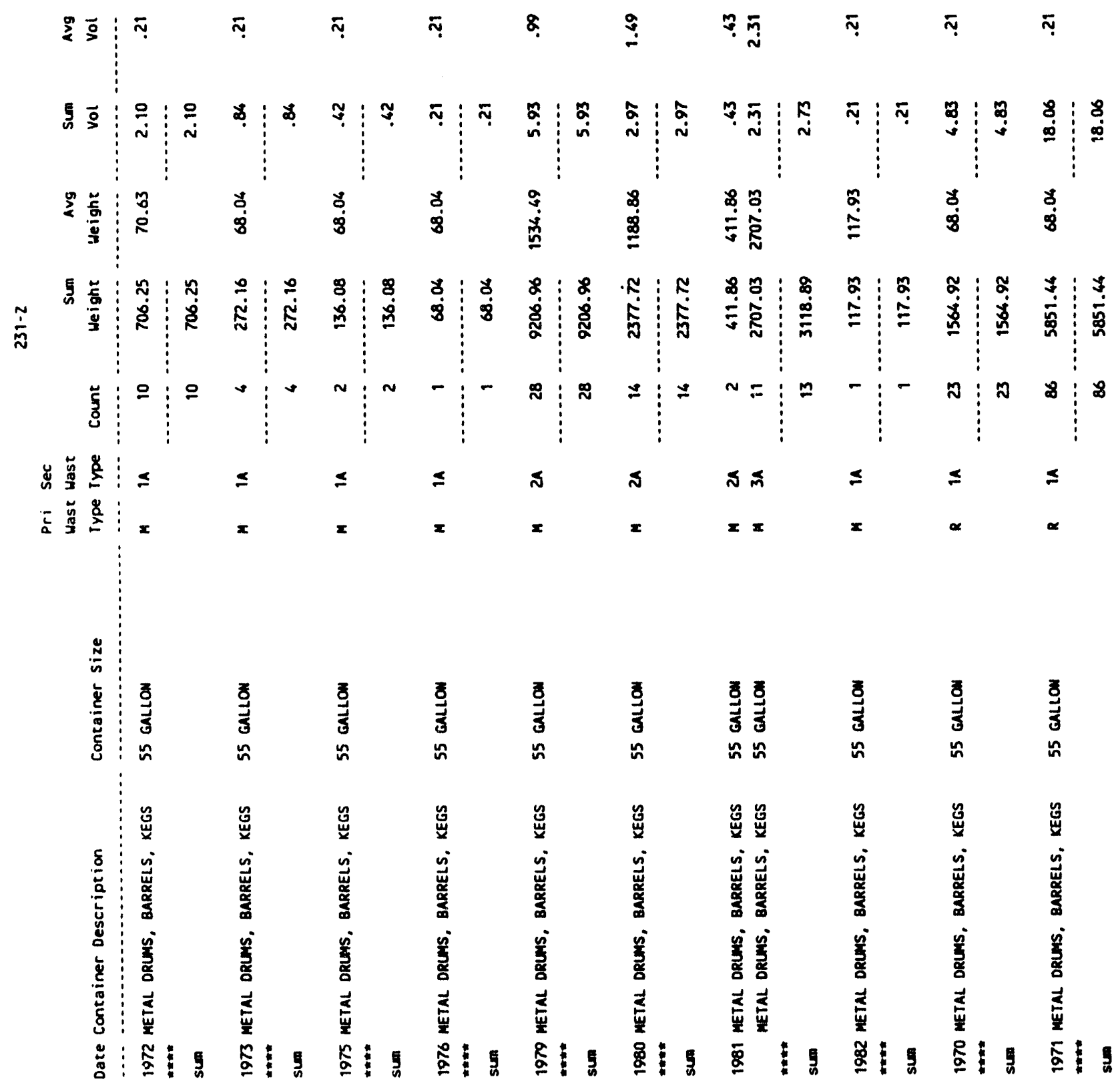




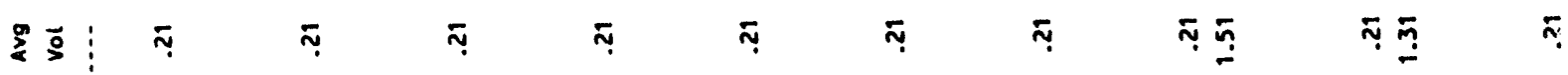

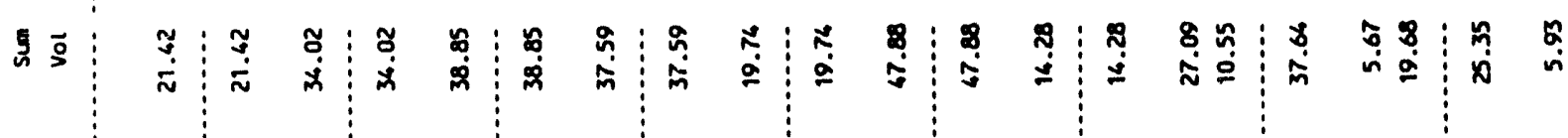

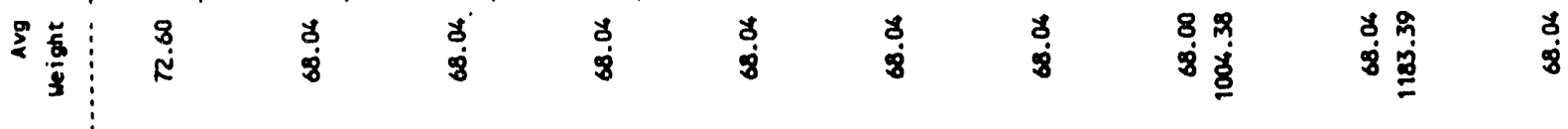

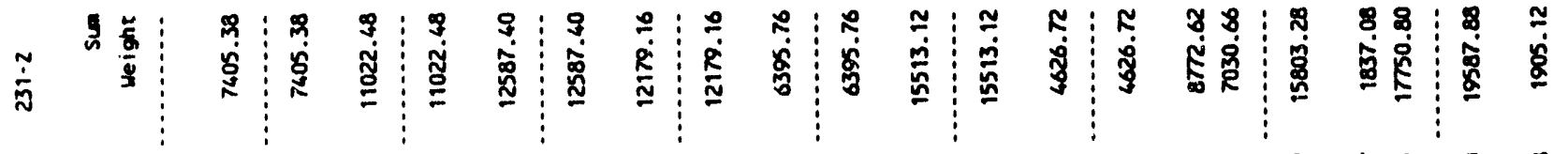

$$
\begin{aligned}
& \text { 芌 }
\end{aligned}
$$

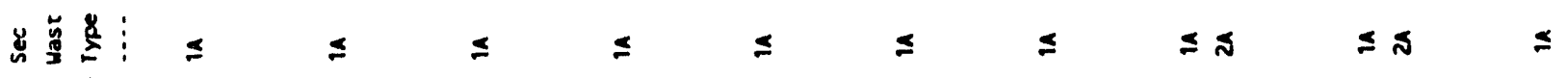

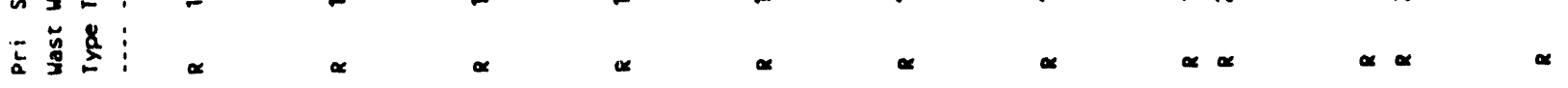

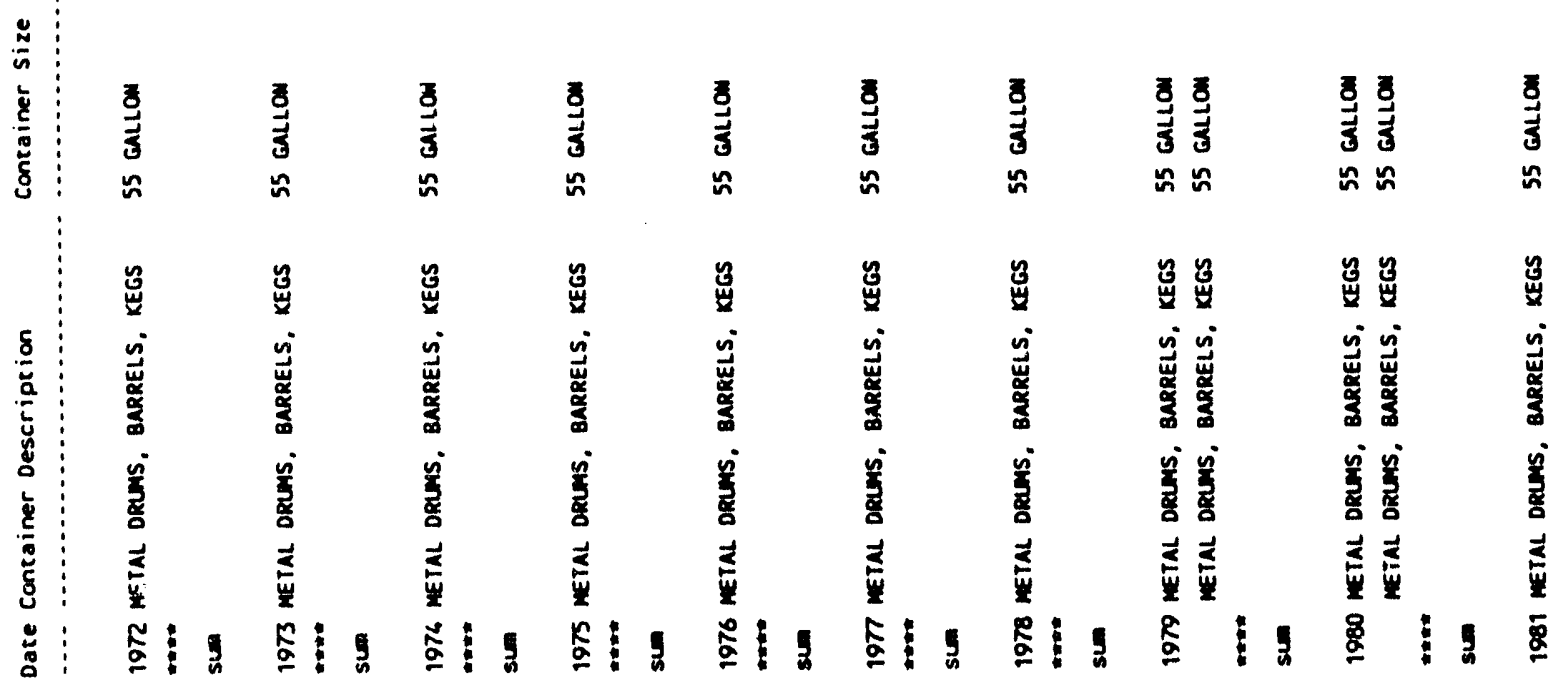




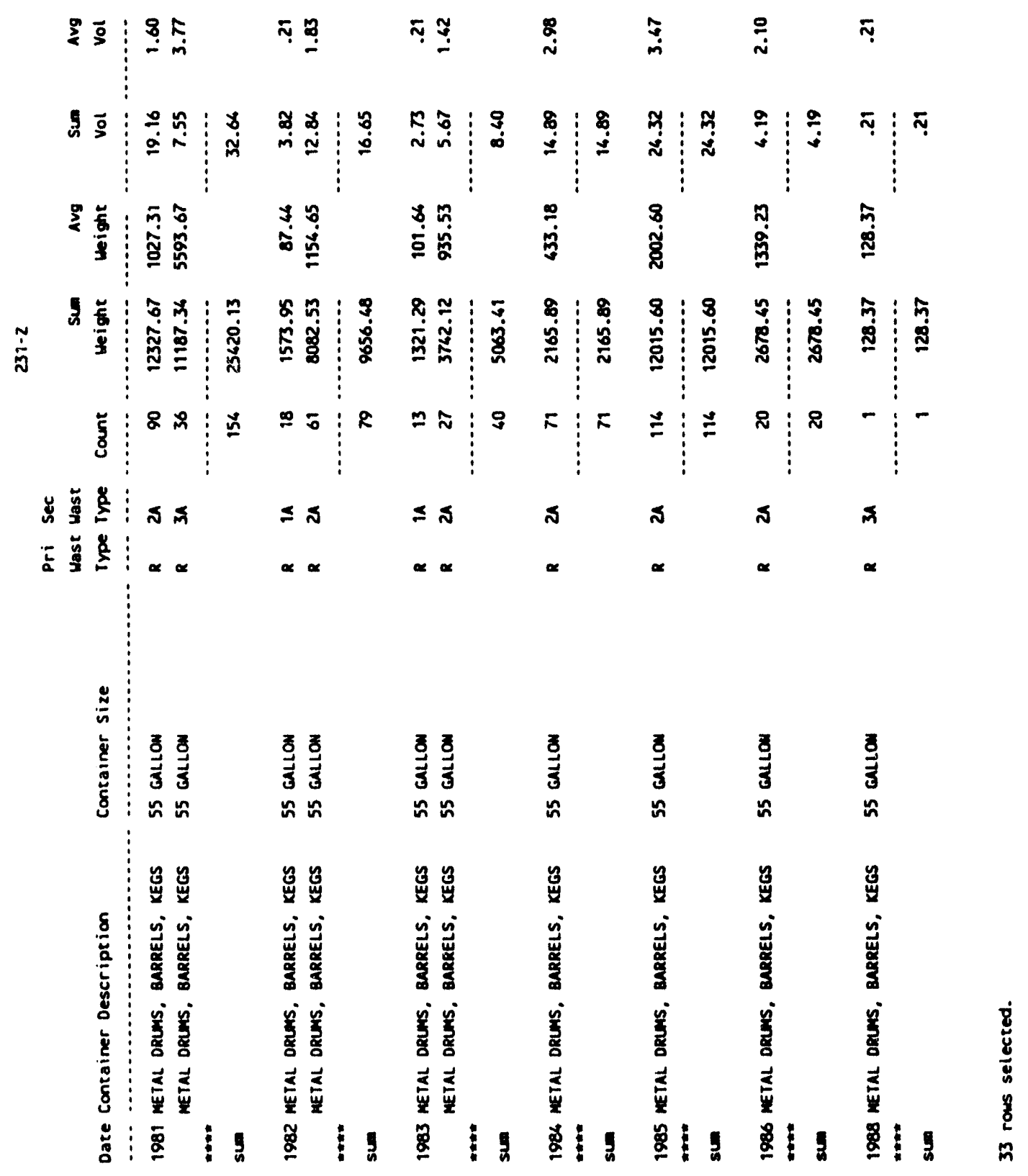


WHC-EP-0659

This page intentionally left blank. 
WHC-EP-0659

\section{APPENDIX A.2}

231-2 TRU WASTE CONTAINERS JORTED BY CONTAINER DESCRIPTION, SIZE, YEAR, AND PRIMARY WASTE TYPE 
WHC-EP-0659

This page intentionally left blank.

A-16 


\section{1-Z TRU WASTE CONTAINERS SORTED BY CONTAINER DESCRIPTION, SIZE, YEAR, AND PRIMARY WASTE TYPE}

This subappendix provides information on the Plutonium Metallurgy Laboratory $(231-Z)$ TRU waste containers' weighi and volume, and the primary waste type stored at various TRU wasie storage facilities on the Hanford Site. The data provide the TRU waste generation from the 231-Z Facility by year. 


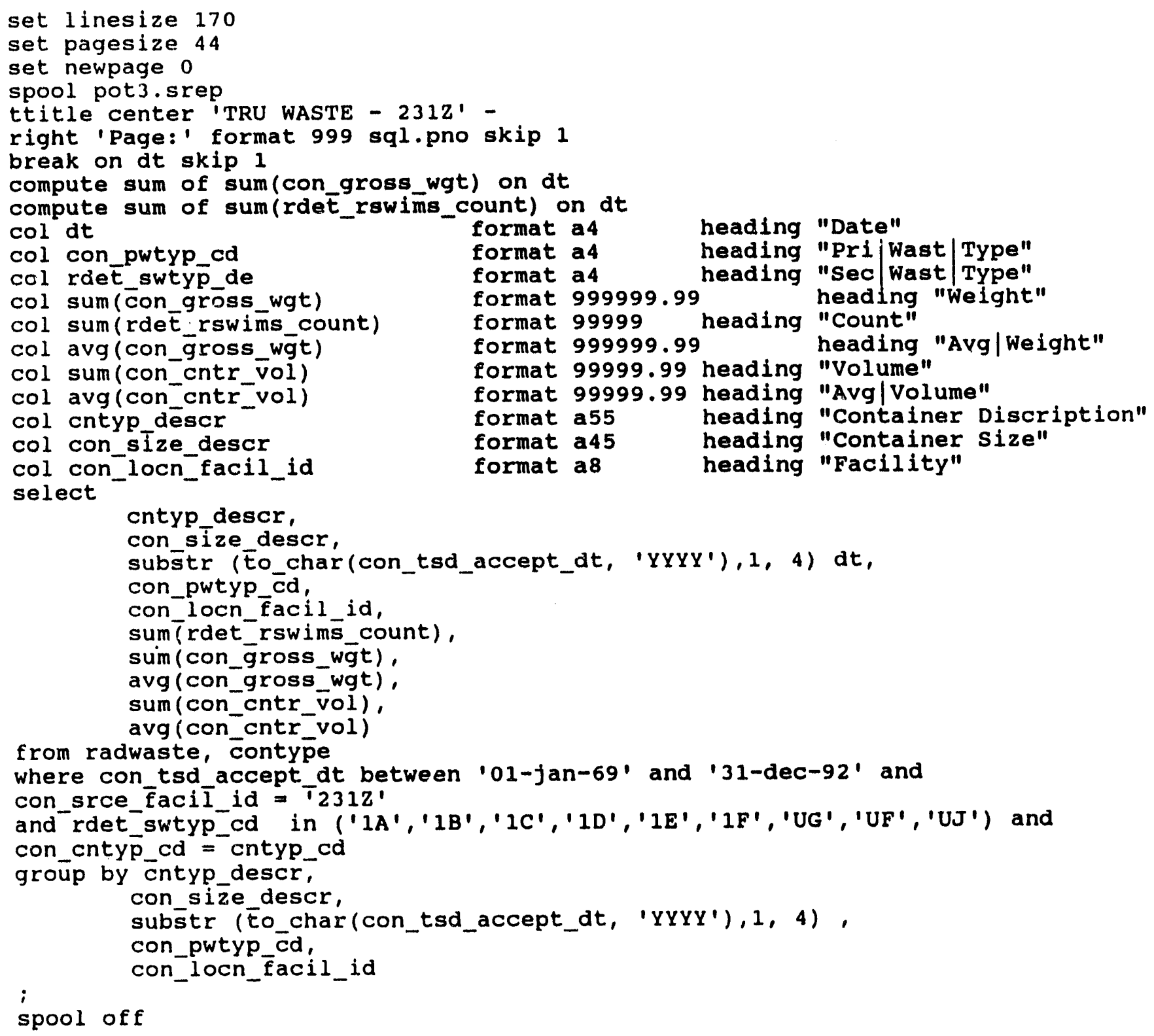
format as heading "Facility"

heading "Date"

heading "Pri|Wast|Type"

heading "Sec Wast Type" heading "Weight" heading "Count" heading "Avg/Weight" 


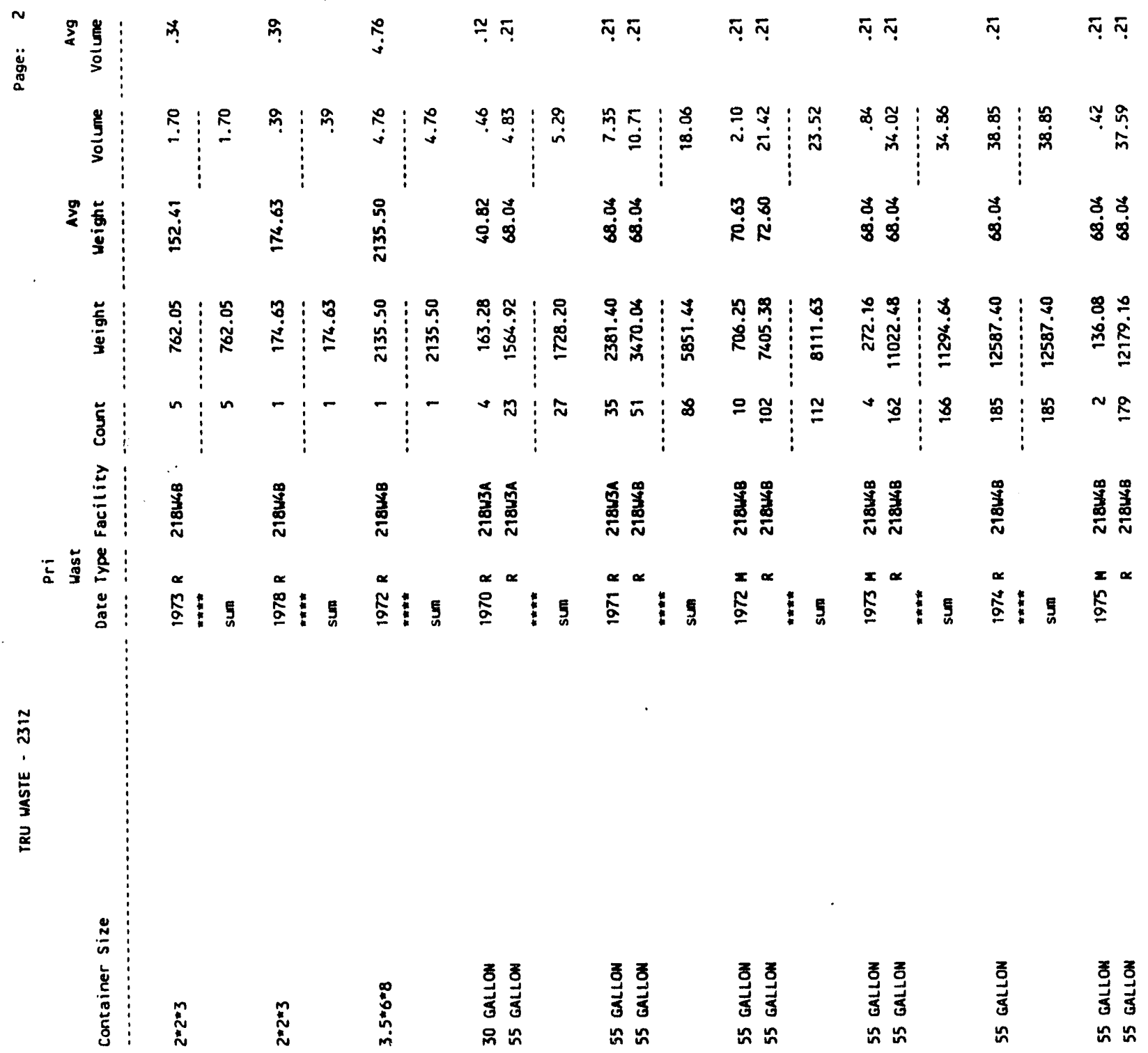


WHC-EP-0659

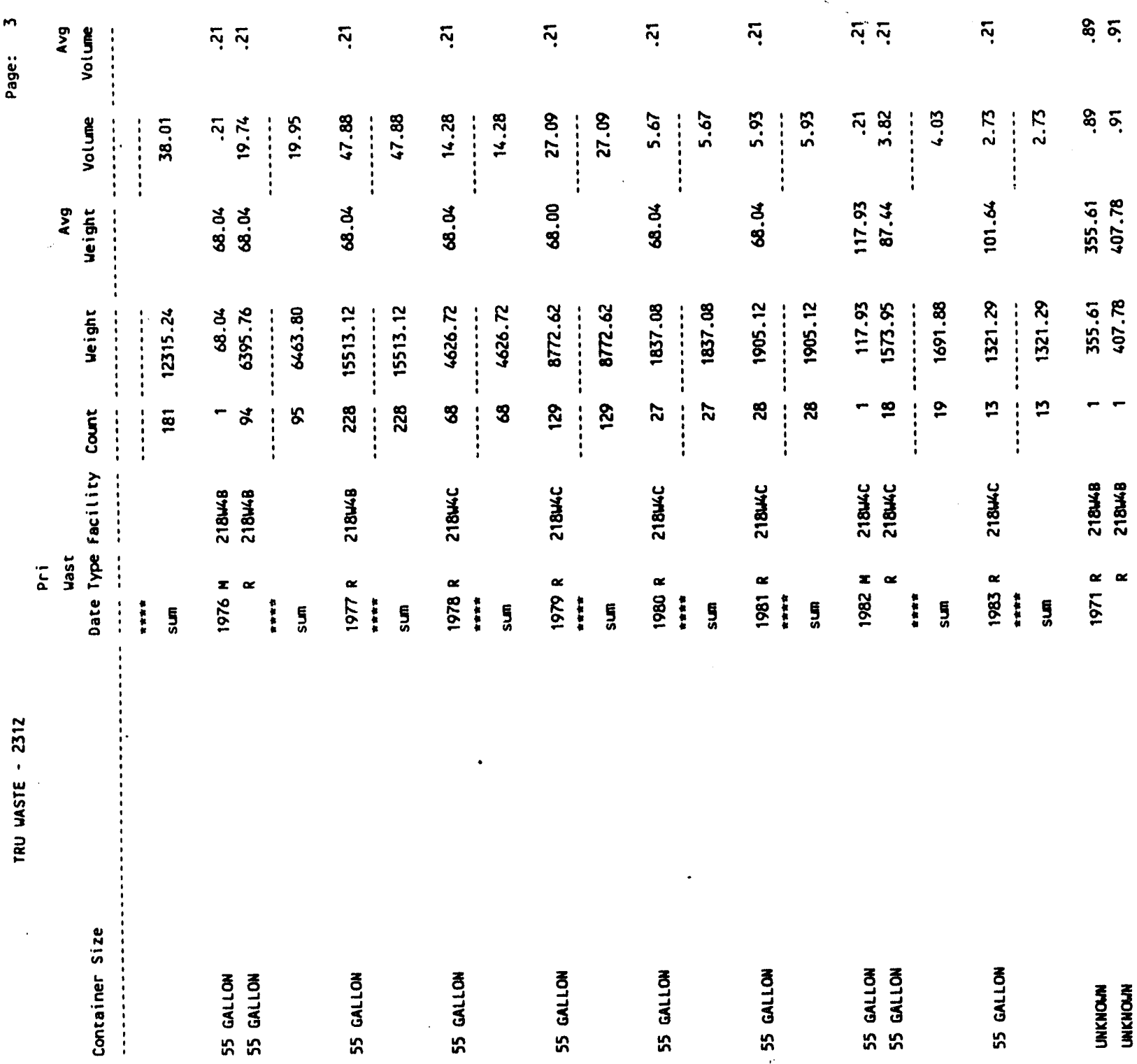

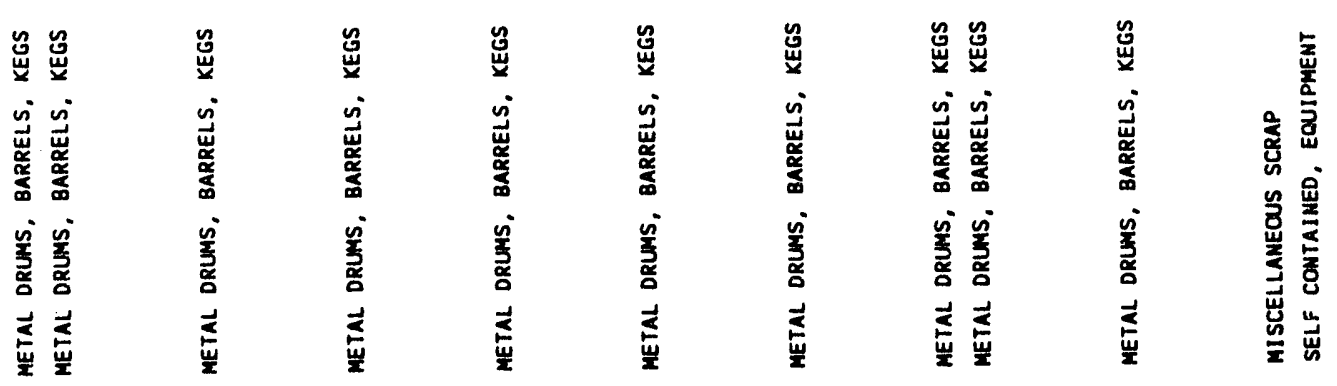




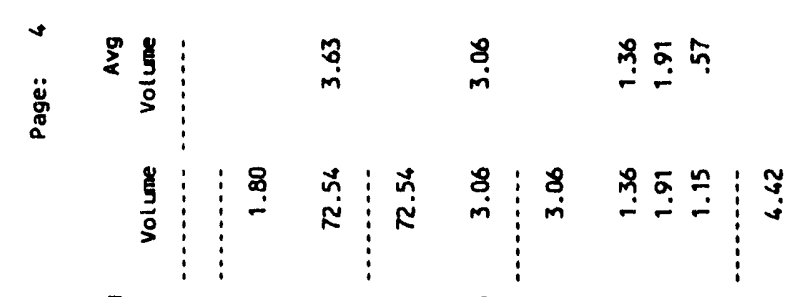

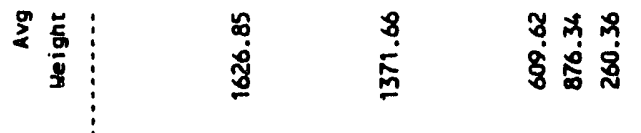

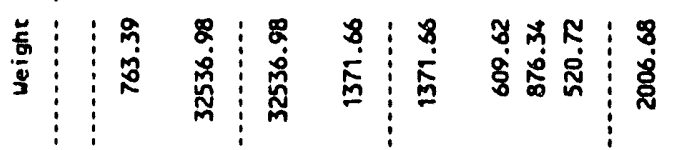

尌

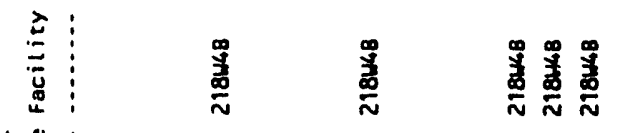

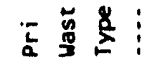

苟

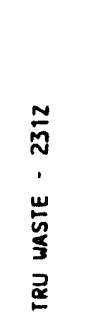

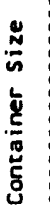

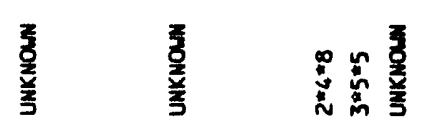

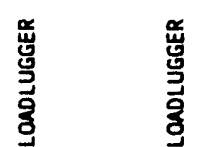

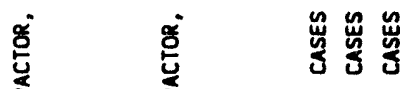

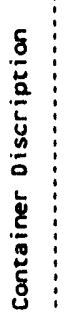

紫范

ป 了

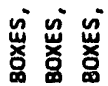

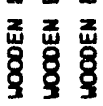

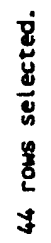


WHC-EP-0659

APPENDIX A.3

231-Z NON-TRU WASTE CONTAINERS SORTED BY CONTAINER DESCRIPTION, SIZE, YEAR, AND PRIMARY WASTE TYPE 


\section{WHC-EP-0659}

This page intentionally left blank. 


\section{1-2 NON-TRU WASTE CONTAINERS SORTED BY CONTAINER DESCRIPTION, SIZE, YEAR, AND PRIMARY WASTE TYPE}

This subappendix provides information on the Plutonium Metallurgy Laboratory (231-Z) non-TRU waste containers' weight and volume, and the primary waste type stored at various waste storage facilities on the Hanford Site. The data provide the non-TRU waste generation from the 231-Z Facility by year. 


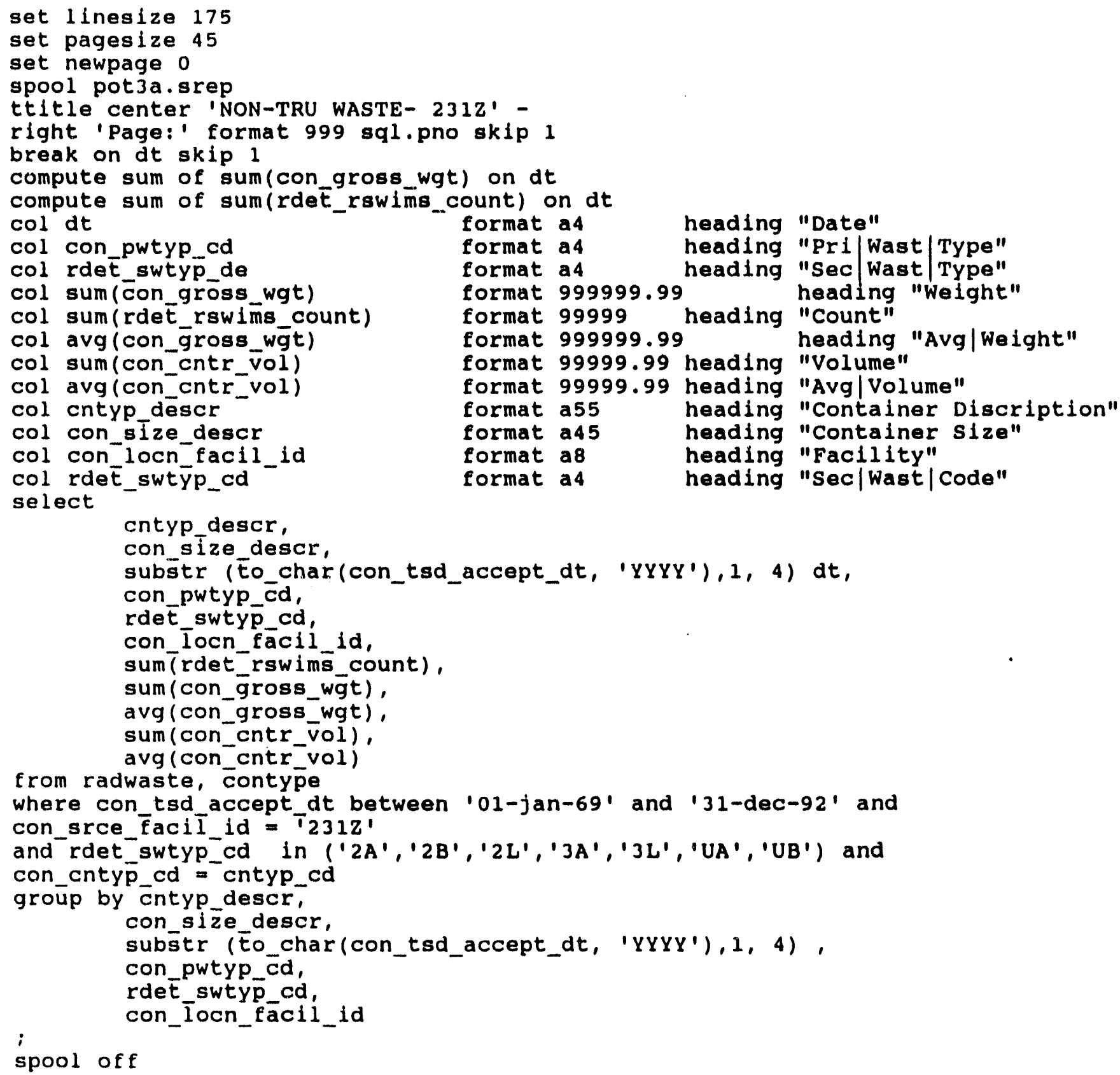


-

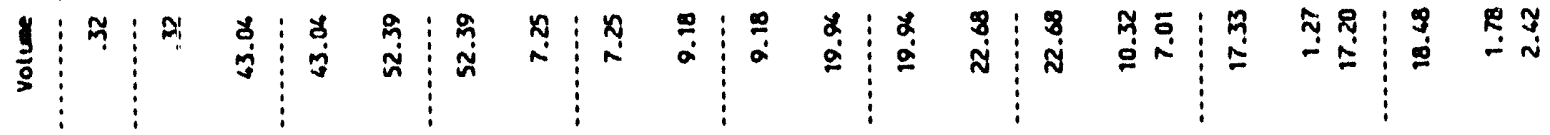

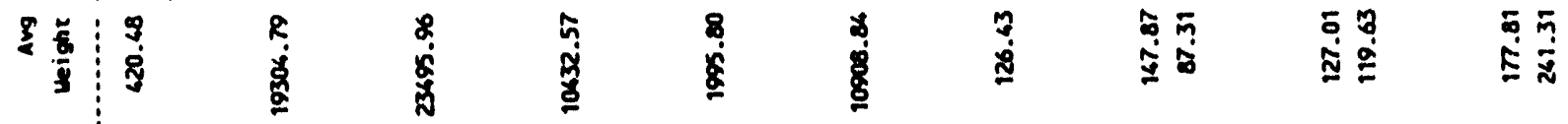

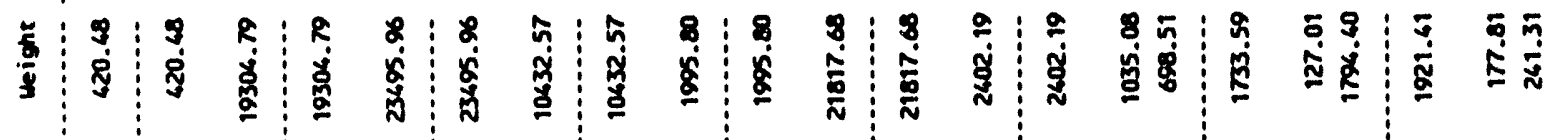

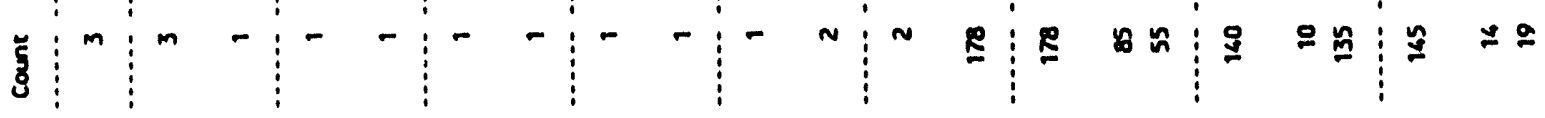

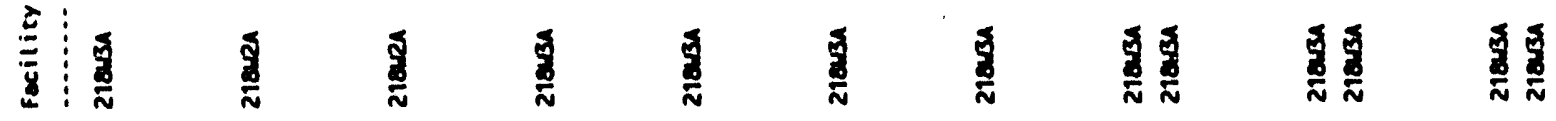

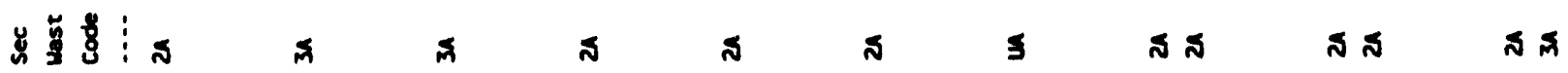

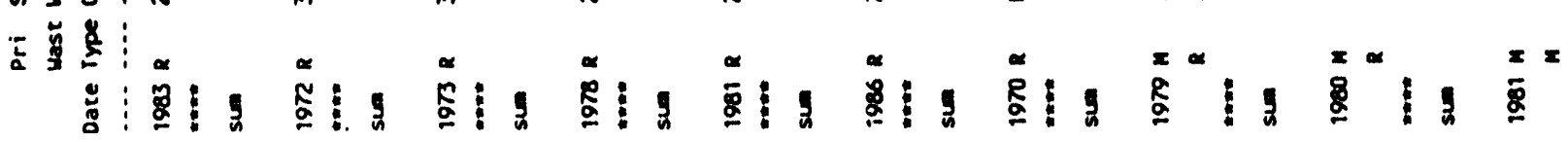

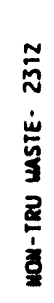
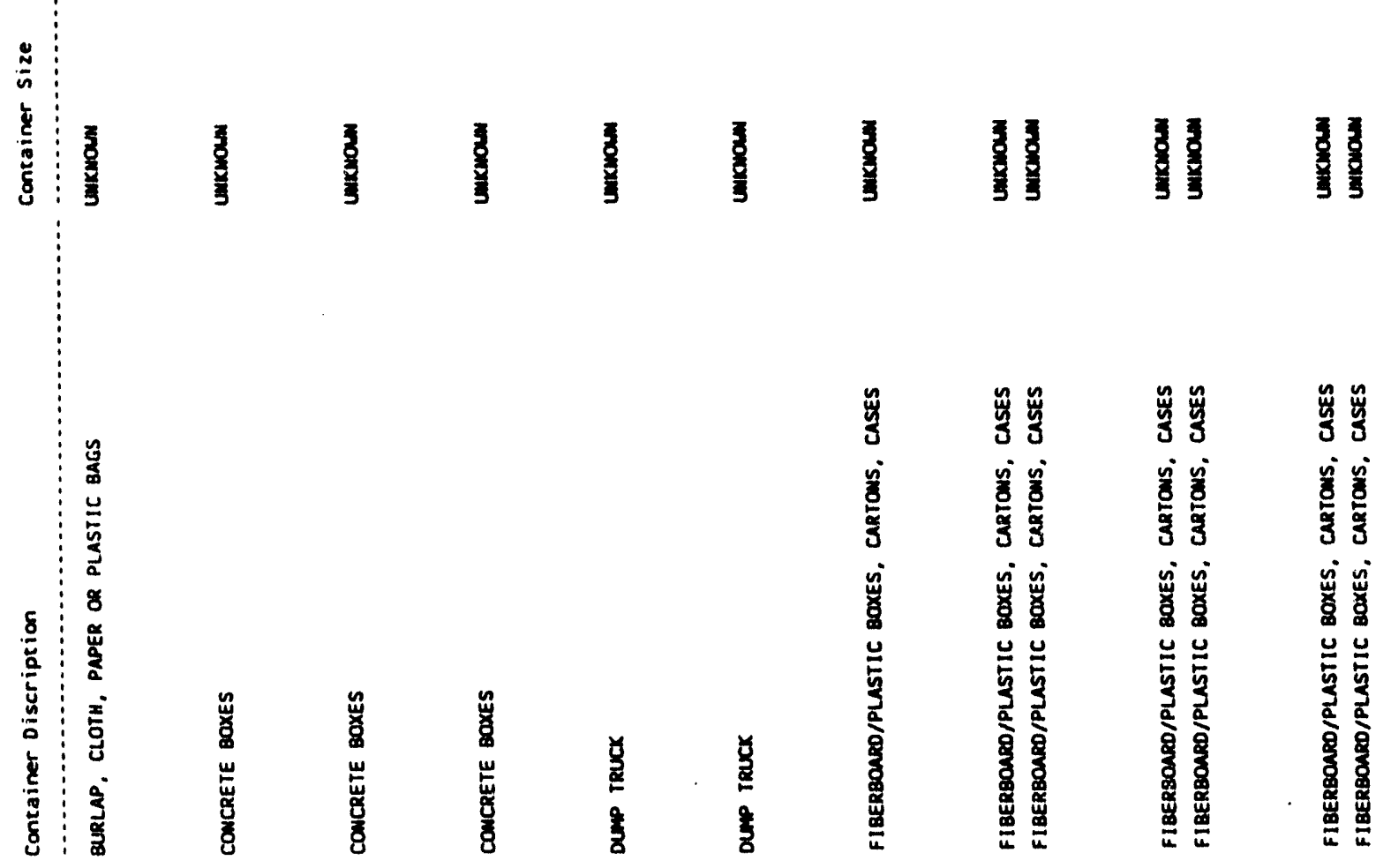
〜 高

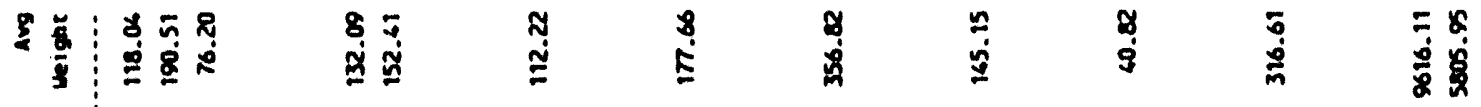

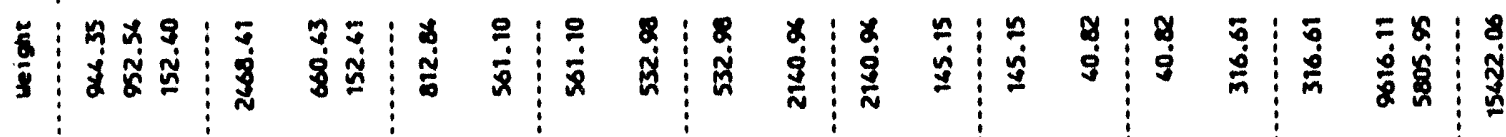
马ु

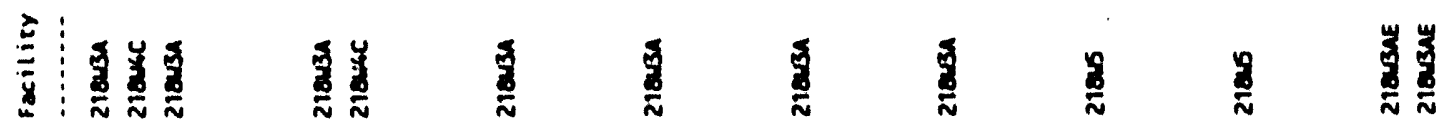

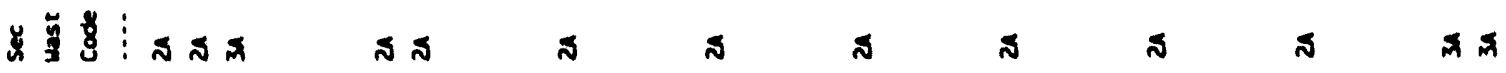

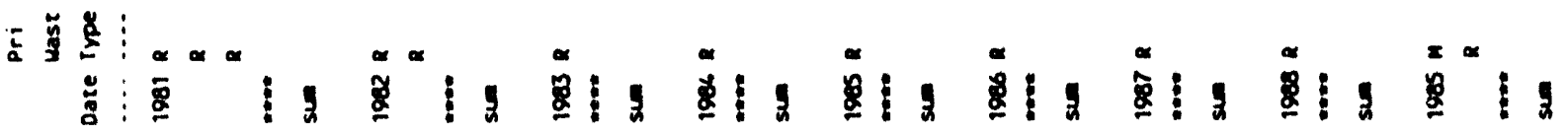

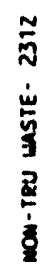

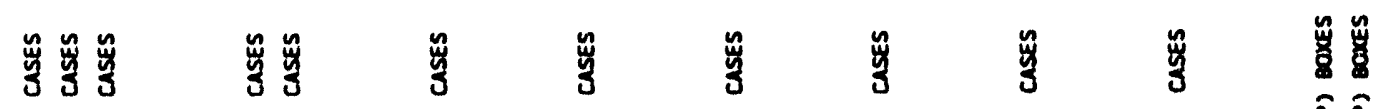

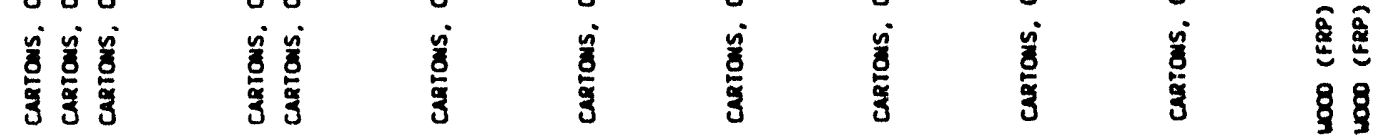




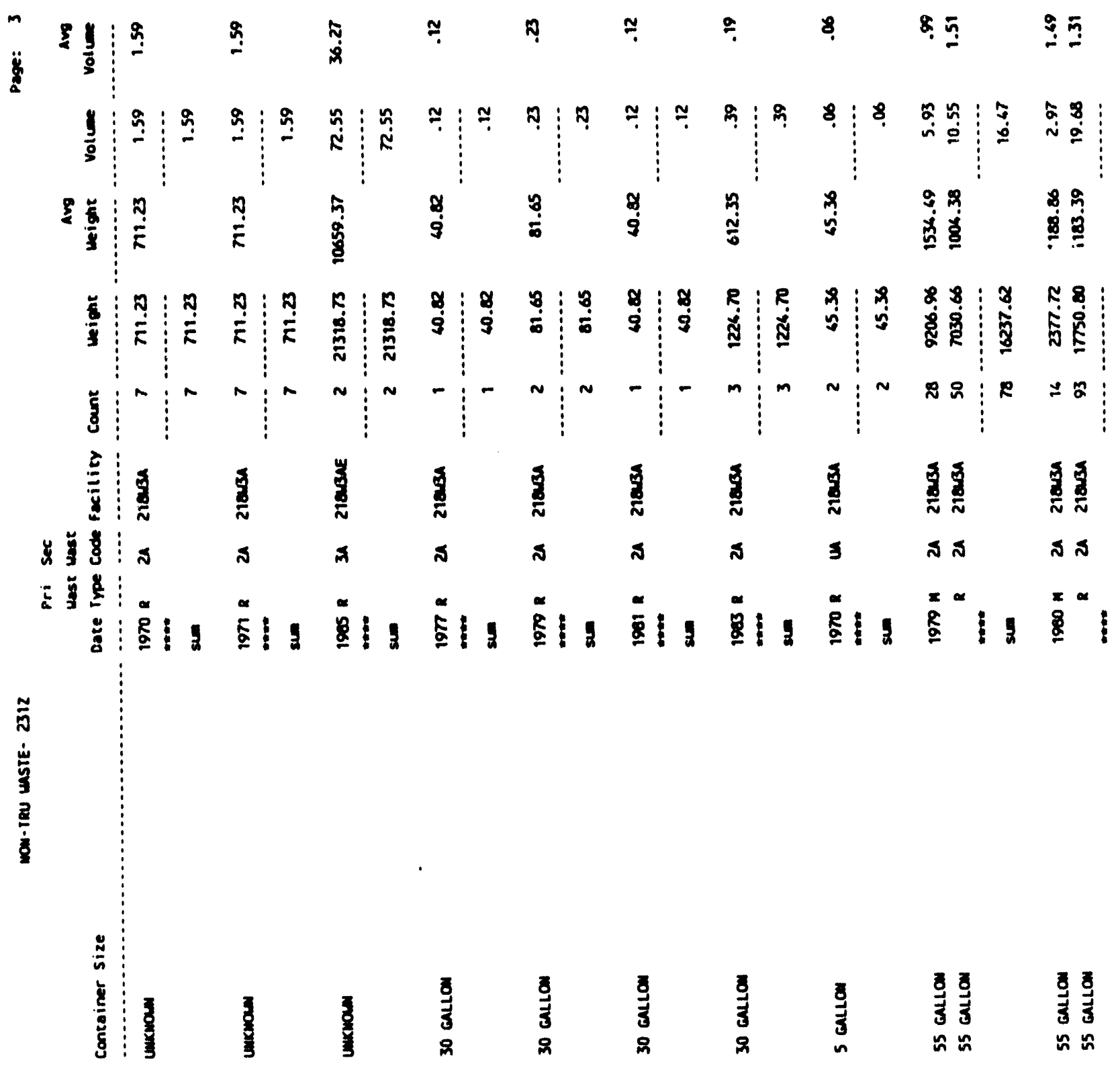



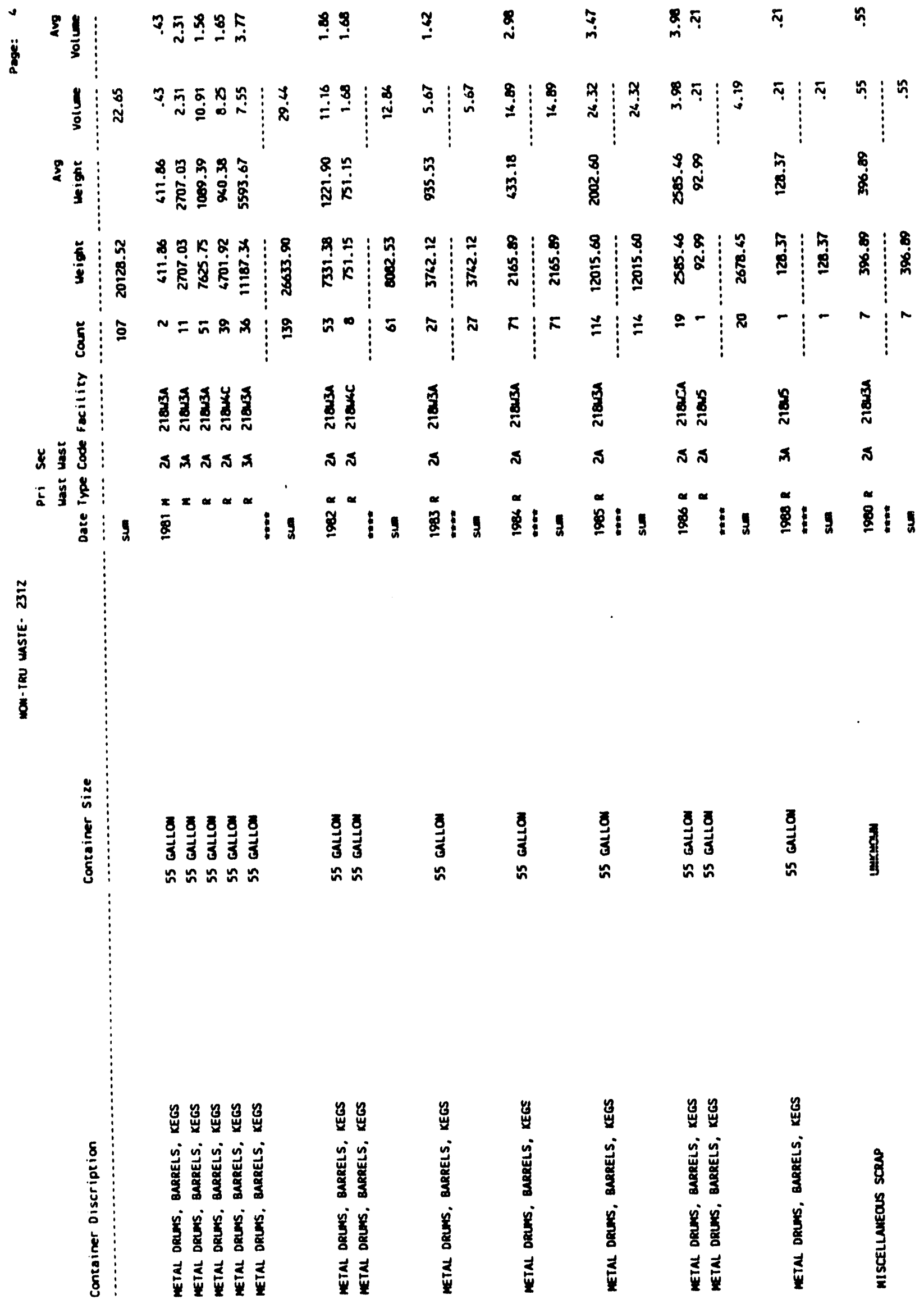


\begin{tabular}{|c|c|c|c|c|c|c|c|c|c|c|c|c|c|c|c|c|}
\hline 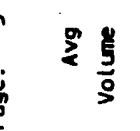 & 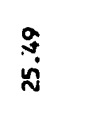 & & $\stackrel{\vec{m}}{\dot{m}}$ & $\stackrel{F}{\sim}$ & & 党 & & $\stackrel{\infty}{\longrightarrow}$ & $\bar{\square}$ & & ఖุ & & مَه هِ & & $\stackrel{g}{\square}$ & $\underset{r}{8}$ \\
\hline$\frac{5}{5}$ & 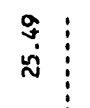 & : & 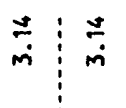 & $\stackrel{n}{\sim}$ & $\stackrel{n}{\sim}$ & 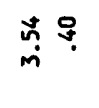 & $\underset{\text { ma }}{\not{m}}$ & $\begin{array}{l:l}\stackrel{\circ}{\circ} & \stackrel{\circ}{-}\end{array}$ & & 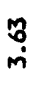 & & 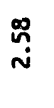 & 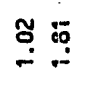 & $\stackrel{\not}{\sim}$ & \begin{tabular}{l:l}
$\vec{f}$ & \multirow{5}{5}{}
\end{tabular} & $\stackrel{5}{a}$ \\
\hline 学䓂 & 雚 & & 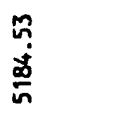 & 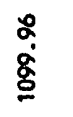 & & 商 & & 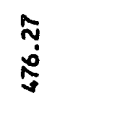 & $\frac{\bar{n}}{\bar{N}}$ & & 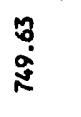 & & 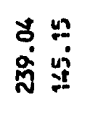 & & $\begin{array}{l}\text { dै } \\
\text { ه్ }\end{array}$ & $\dot{s}$ \\
\hline 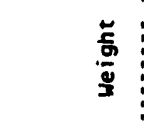 & 雚: & 誉 & 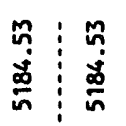 & 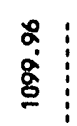 & $\begin{array}{l}\not 2 \\
\stackrel{2}{\alpha}\end{array}$ & 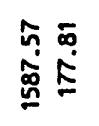 & : & 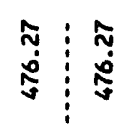 & $\begin{array}{l:}\stackrel{\widetilde{\leftrightarrow}}{\tilde{g}} \\
\end{array}$ & ֻั: & \begin{tabular}{l|l}
8 & \\
\multirow{3}{*}{} &
\end{tabular} & $\begin{array}{l}8 \\
\text { d. }\end{array}$ & 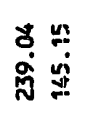 & $\frac{a}{\dot{j}}$ & 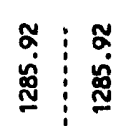 & $\begin{array}{l}\bar{n} \\
\bar{g} \\
\bar{g}\end{array}$ \\
\hline & & $\circ$ & & - & - & in $\mathrm{m}$ & $\infty$ & & & $\infty$ & & 4 & & $\sim$ & $=$ & \\
\hline & $\begin{array}{l}\tilde{u} \\
\stackrel{\vec{w}}{\sim}\end{array}$ & & 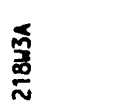 & $\underset{\underset{\sim}{\tilde{m}}}{\sim}$ & & 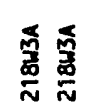 & & 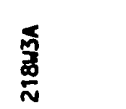 & 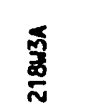 & & 息 & & 䆠 & & 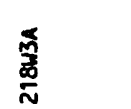 & 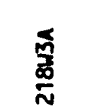 \\
\hline 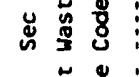 & $\approx$ & & న & $\Phi$ & & s క & & న & s & & న & & $\pi \mathbb{N}$ & & s & \\
\hline : & $\stackrel{\alpha}{\bar{\alpha}}$ & & \begin{tabular}{l|l}
$\alpha$ \\
$\Phi$ \\
$\Phi$
\end{tabular} & 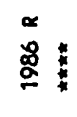 & & $\stackrel{\alpha}{\alpha}^{\alpha}$ & 5 & $\stackrel{\alpha}{\alpha}$ & $\stackrel{\alpha}{\alpha}$ & & & 5 & & & 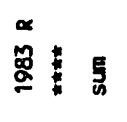 & \\
\hline
\end{tabular}

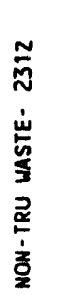

:

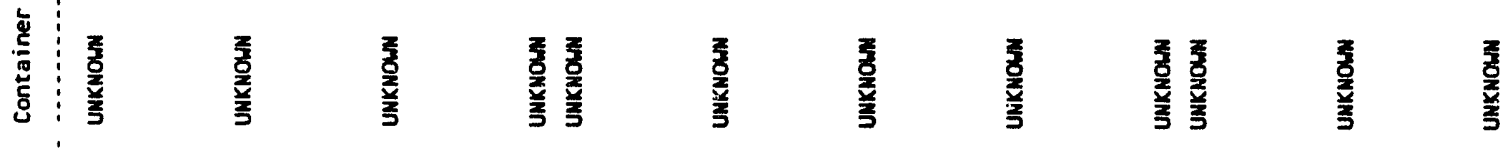
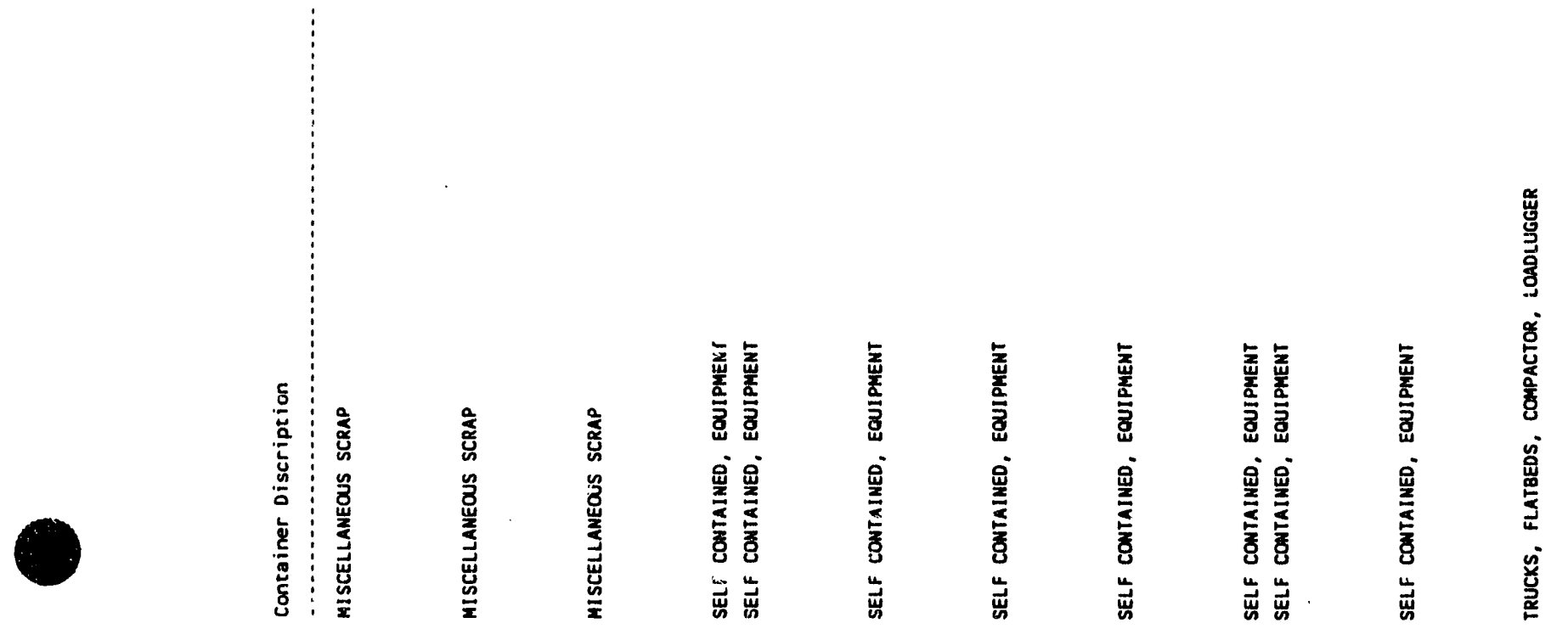


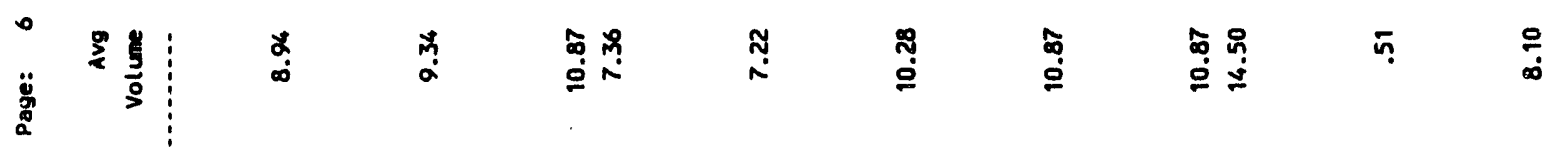

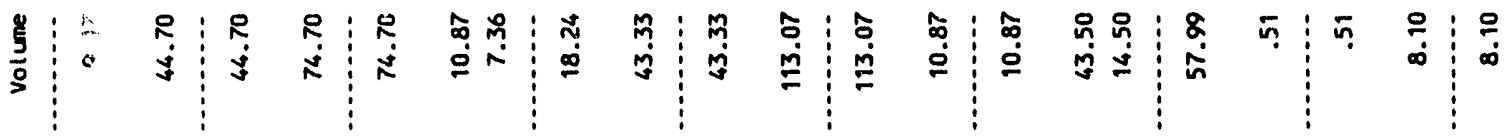

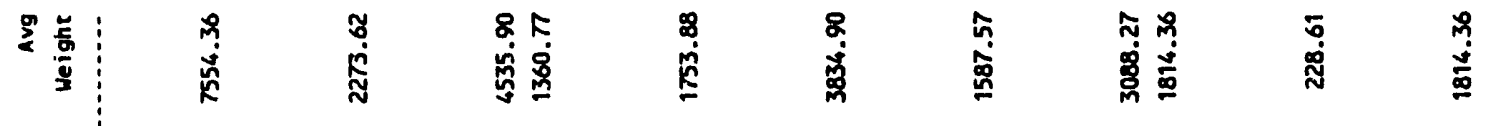

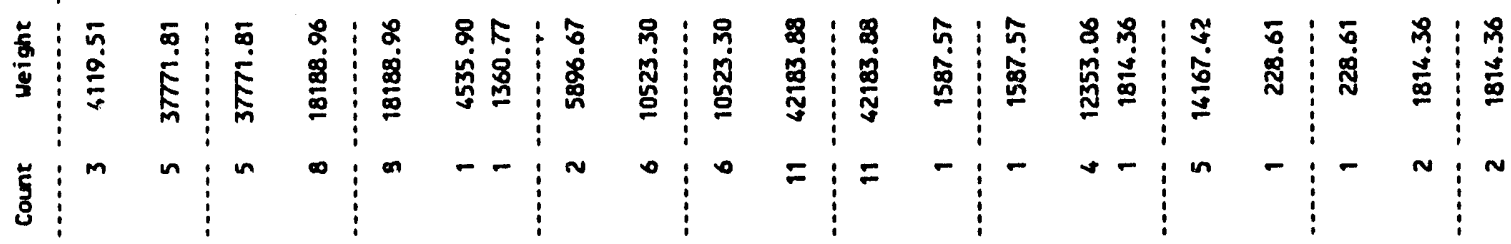

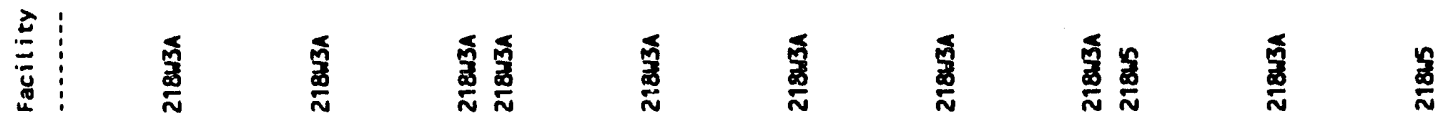

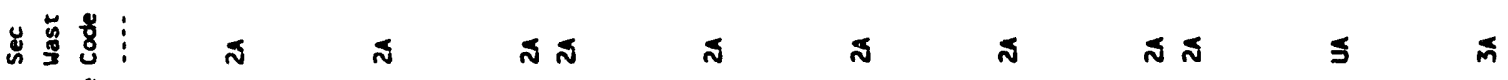

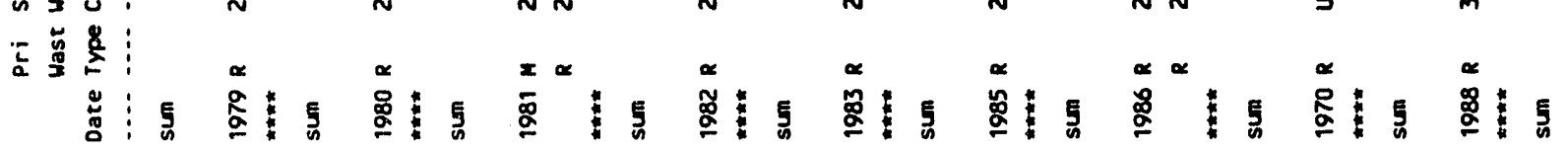

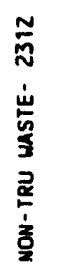

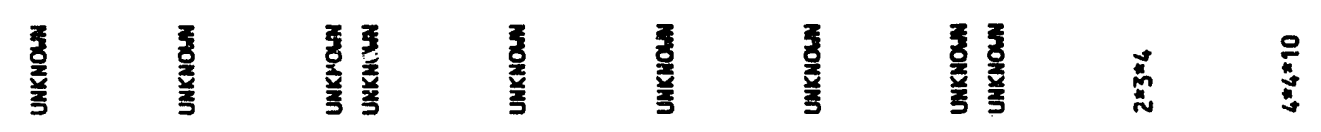

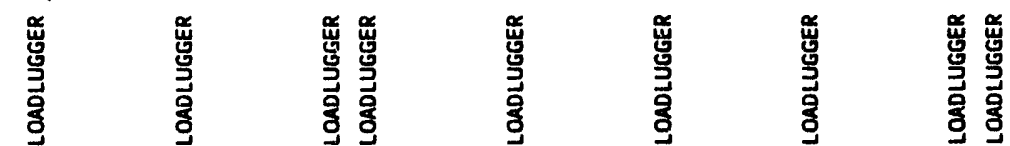

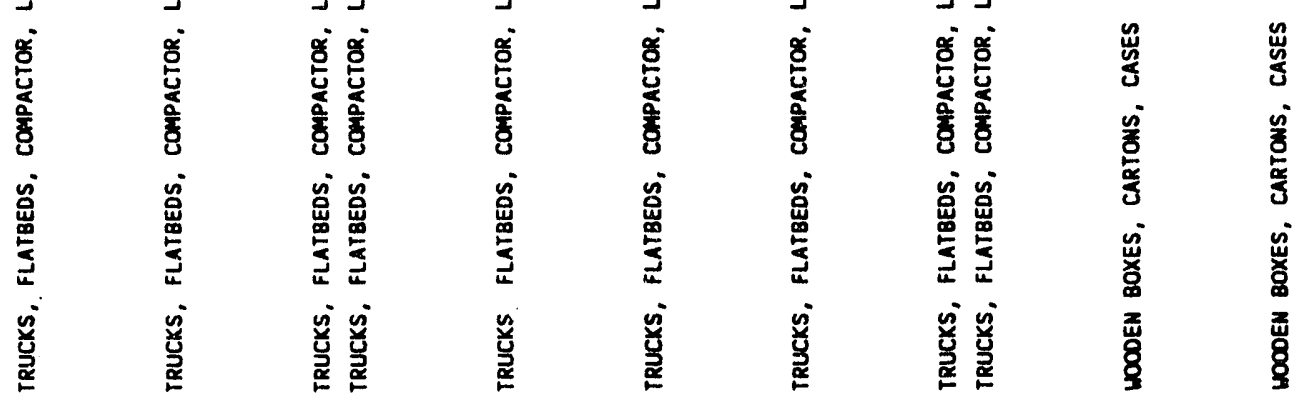


WHC-EP-0659

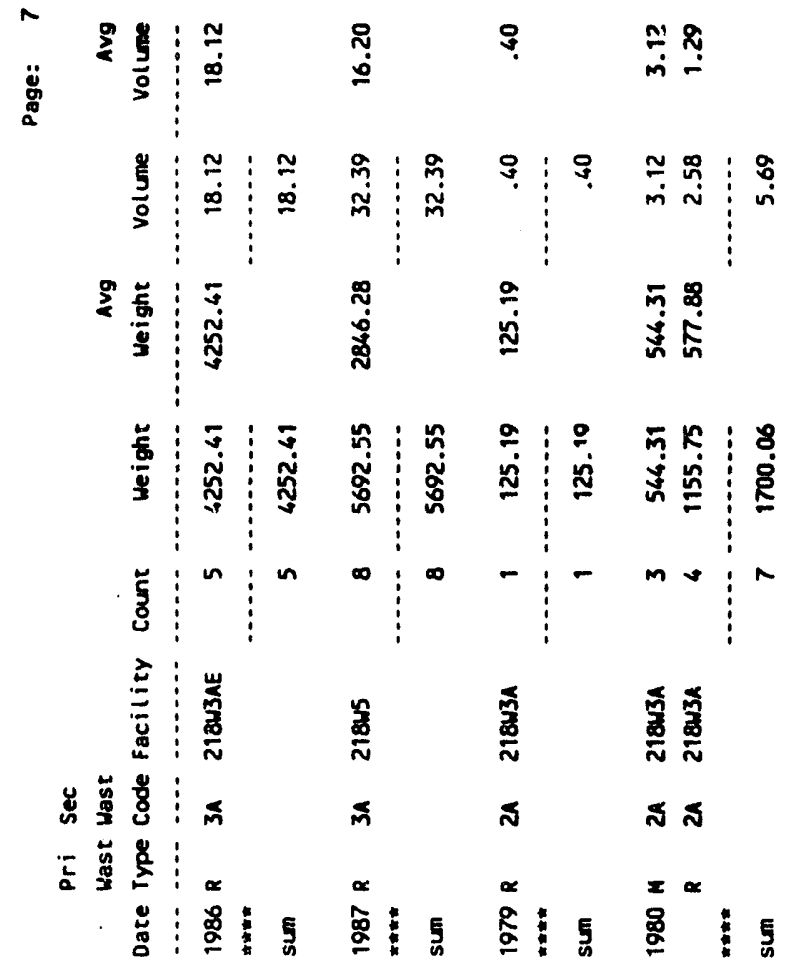

N

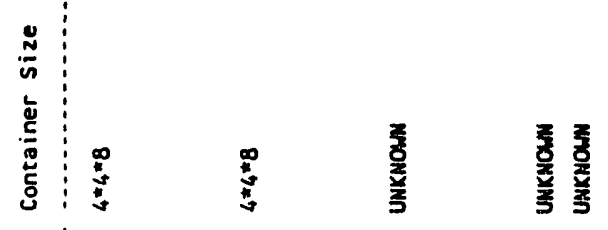


WHC-EP-0659

This page intentionally left blank. 
WHC-EP-0659

APPENDIX A.4

RADIOLOGICAL DATA FOR TRU WASTE CONTAINERS SORTED BY DATE, PRIMARY WASTE TYPE, AND STORAGE FACILITY 
WHC-EP-0659

This page intentionally left blank. 


\section{RADIOLOGICAL DATA FOR TRU WASTE CONTAINERS SORTED BY DATE, PRIMARY WASTE TYPE, AND STORAGE FACILITY}

This subappendix summarizes the radiological data for all TRU waste containers generated at Plutonium Metallurgy Laboratory (231-Z). Specifically, this computer run provides the total grams of TRU elements in a given container type in a given year. In addition, the average gram loading for a given container type in a given year has been calculated.

In 1991 and 1992 the number of curies of alpha radiation was included on the Solid Waste Burial Records (SWBRs). Since the 231-Z waste generation data are all from 1969 to 1988 , these columns contain blank entries. The "Max Dose" column contains the highest value recorded for a given container in a given year, in $\mathrm{mrem} / \mathrm{h}$.

Additional information about the isotopes present in $231-Z$ waste containers can be found in subappendixes A.9 and A.10. 


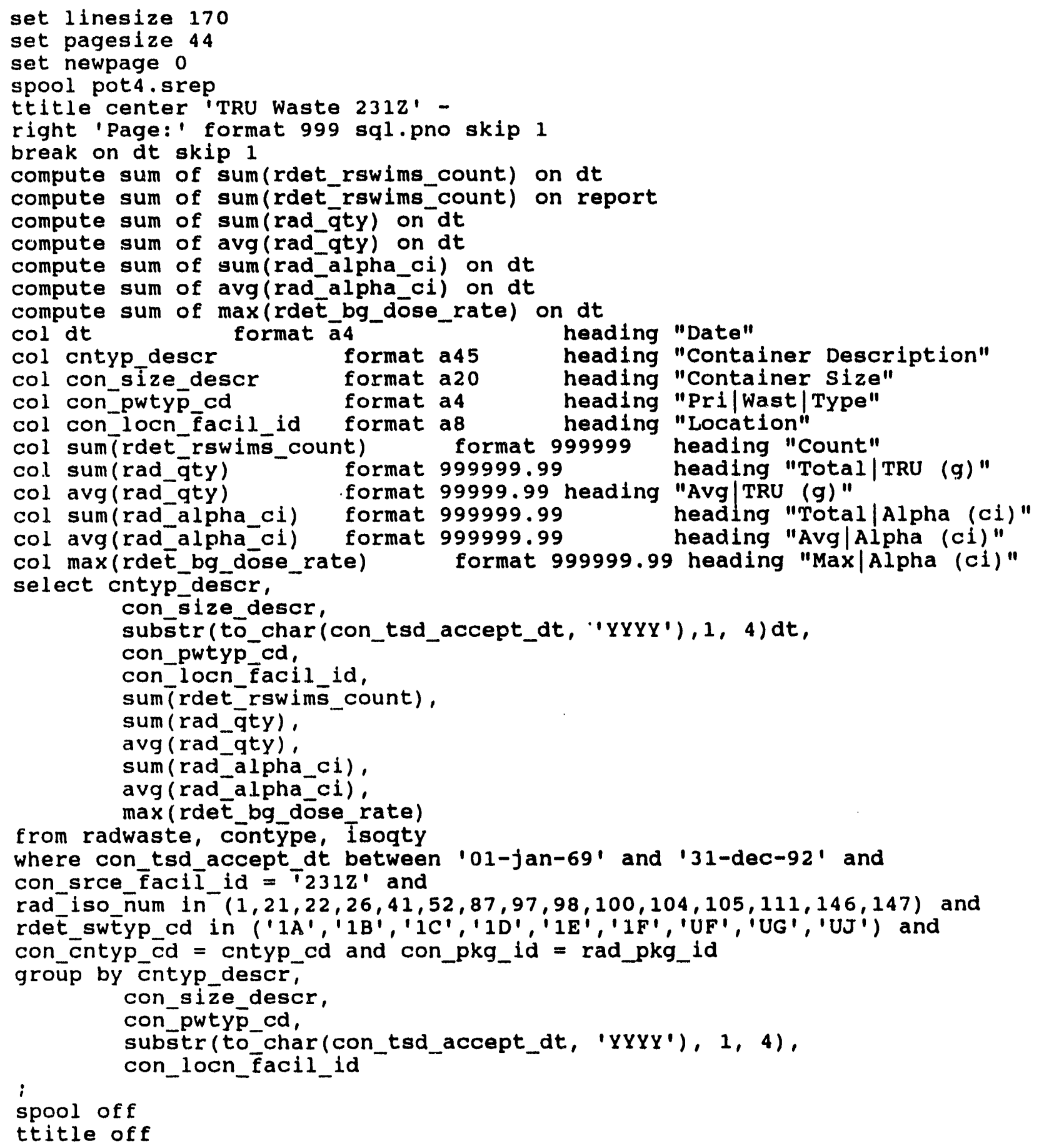


\%ั

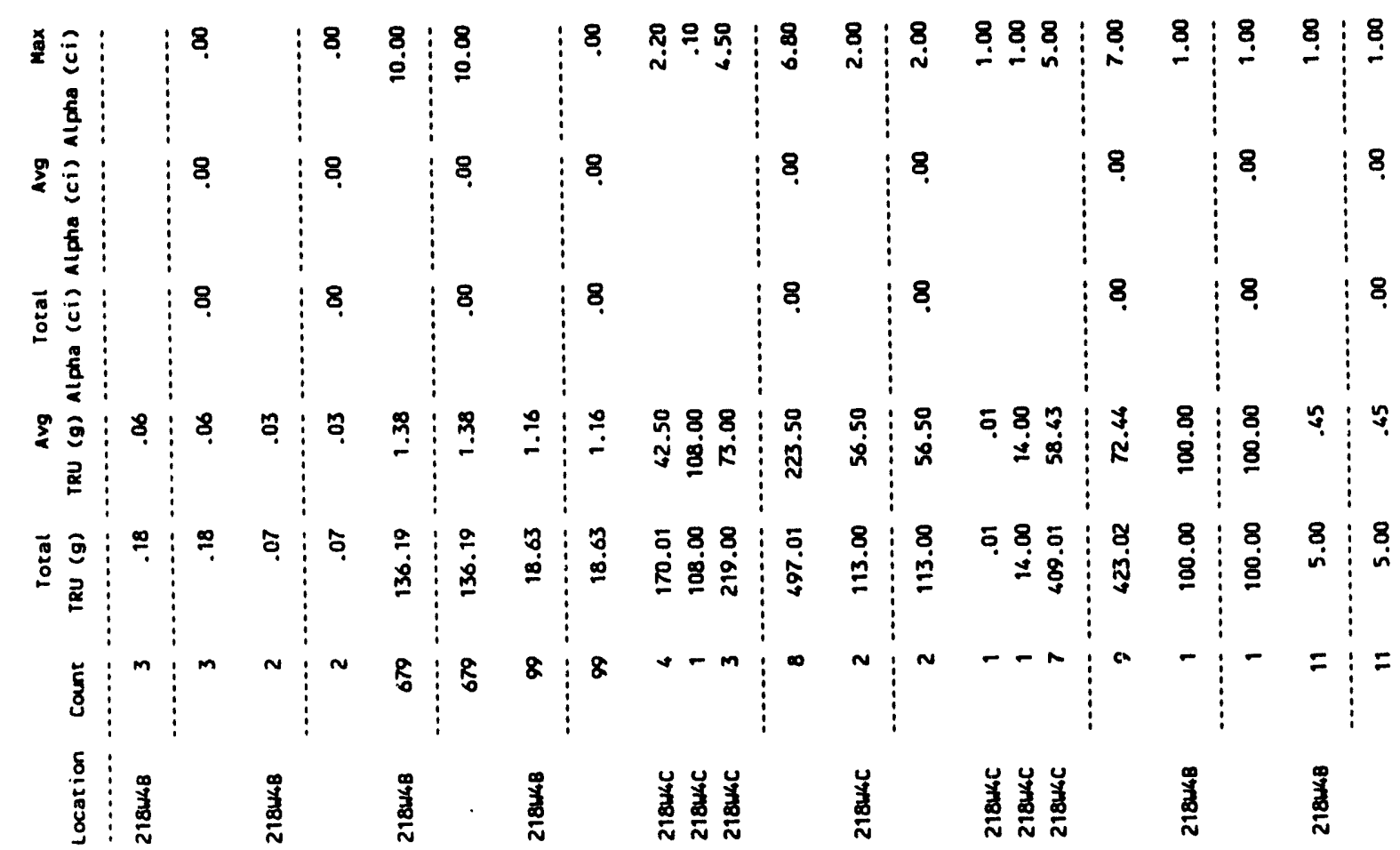
巨龺喜

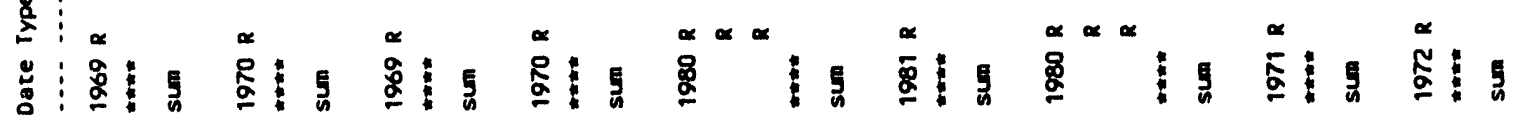

$\frac{n}{n}$

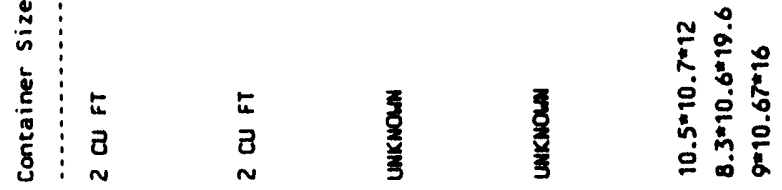

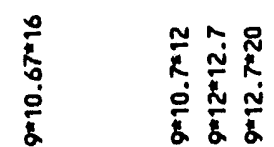

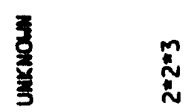

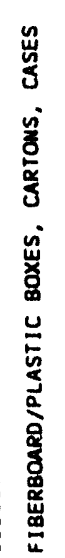

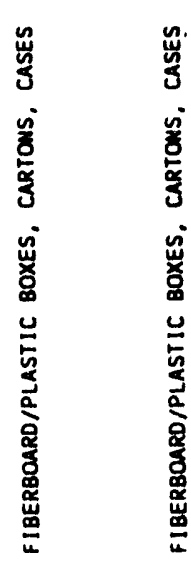

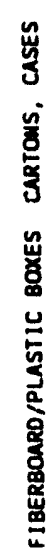

繁鲳

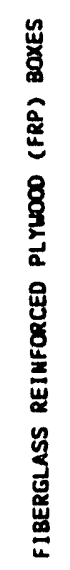

曾鲁

ำ

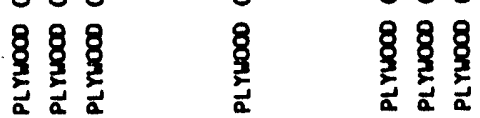

兽

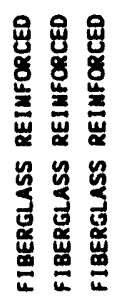

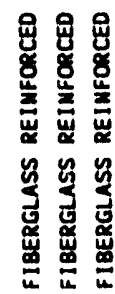

染

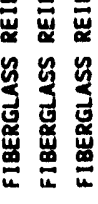

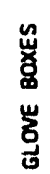


$\ddot{8}$

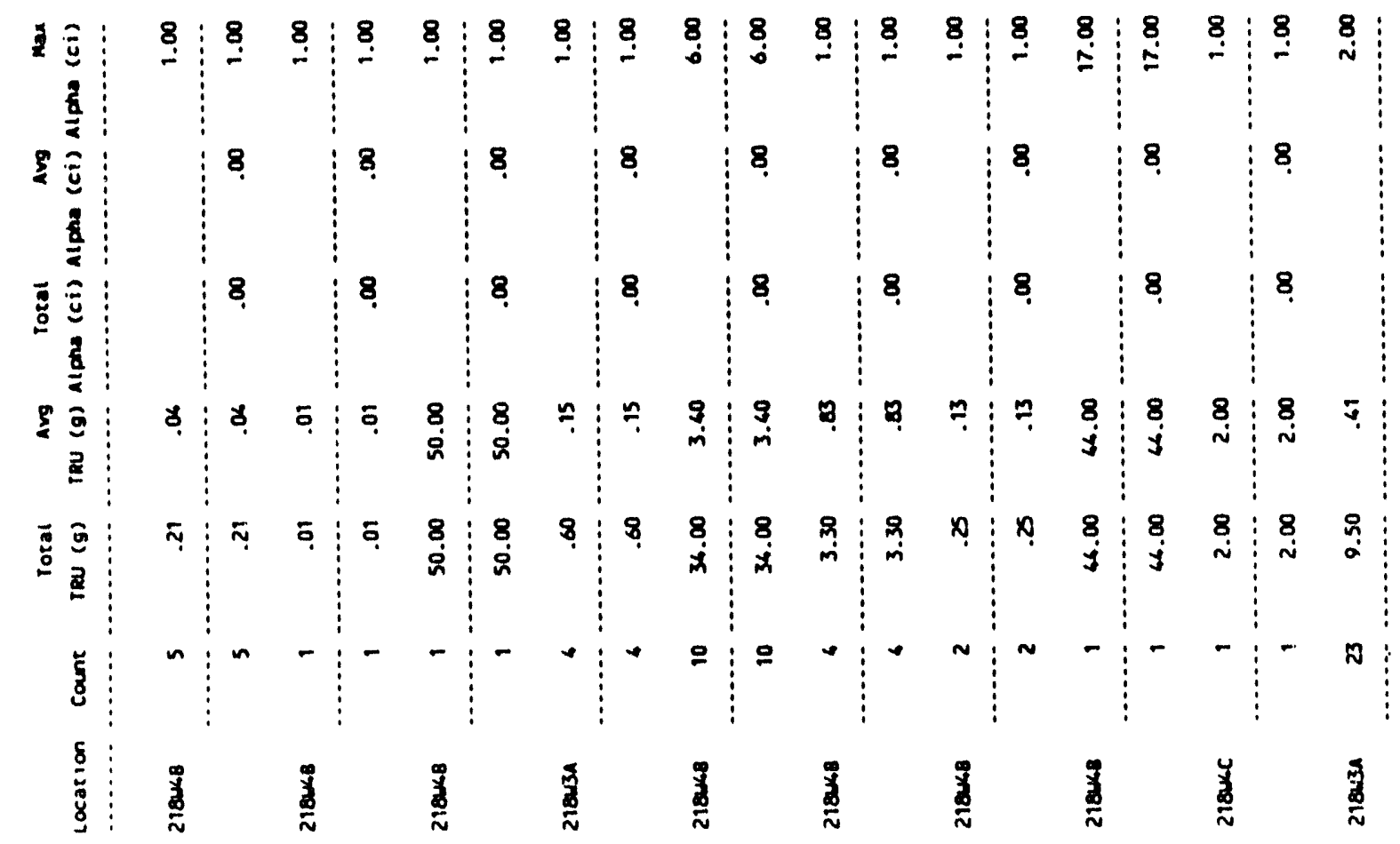

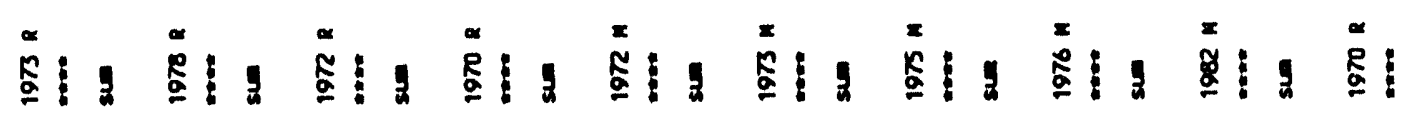

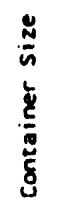

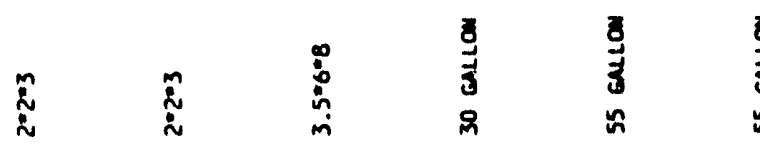

焉

$\underset{3}{3}$

$\frac{3}{3}$
n
$n$

$\frac{3}{3}$

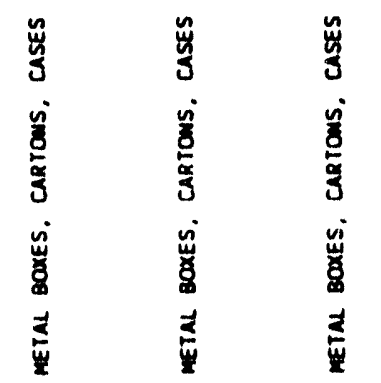

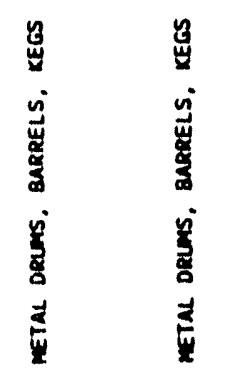

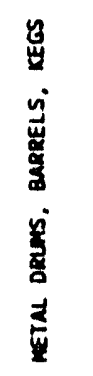

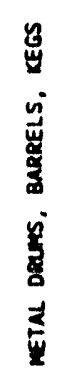

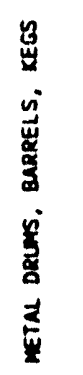

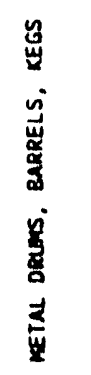

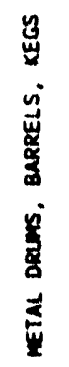




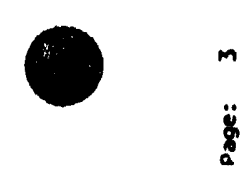

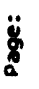

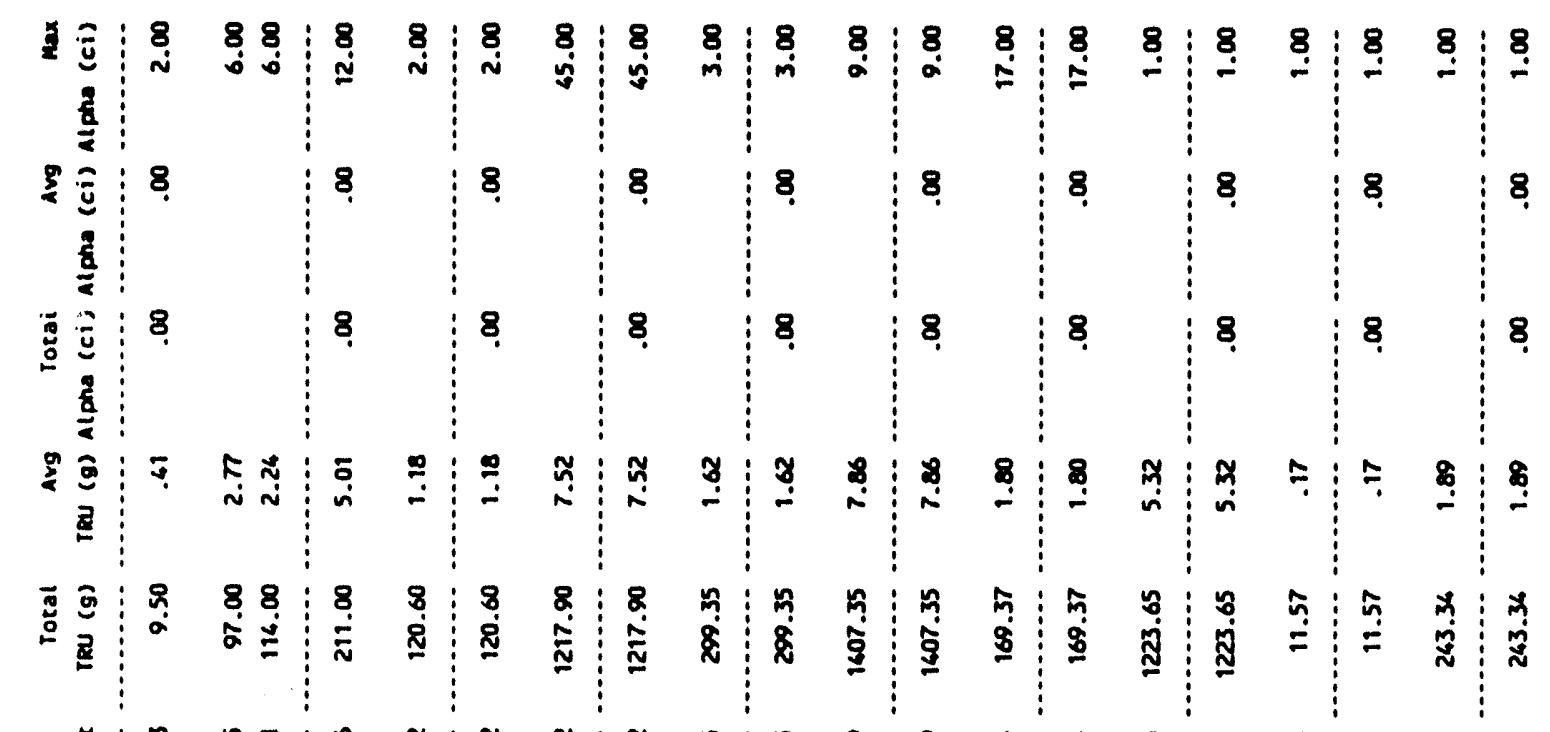

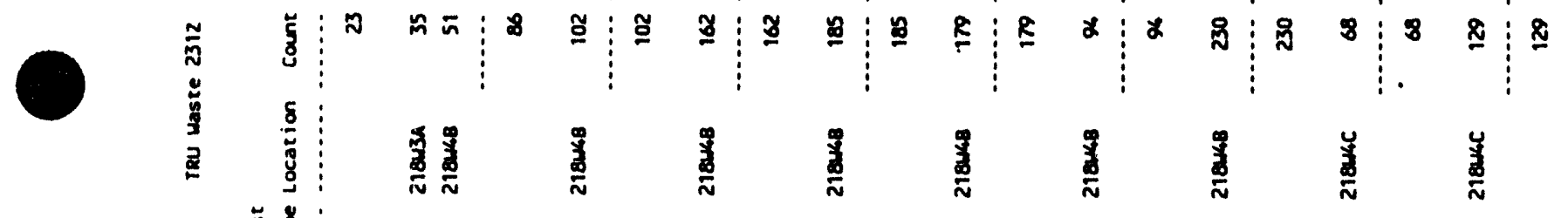

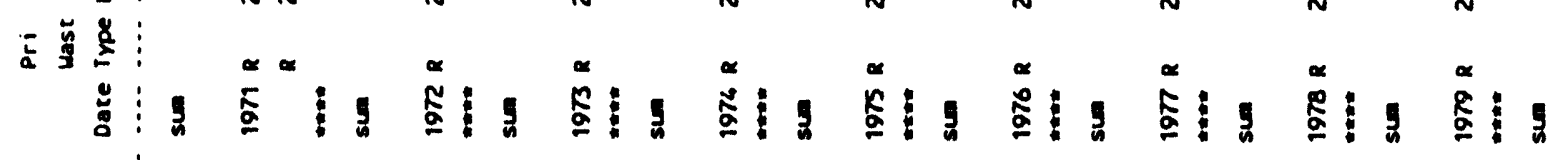

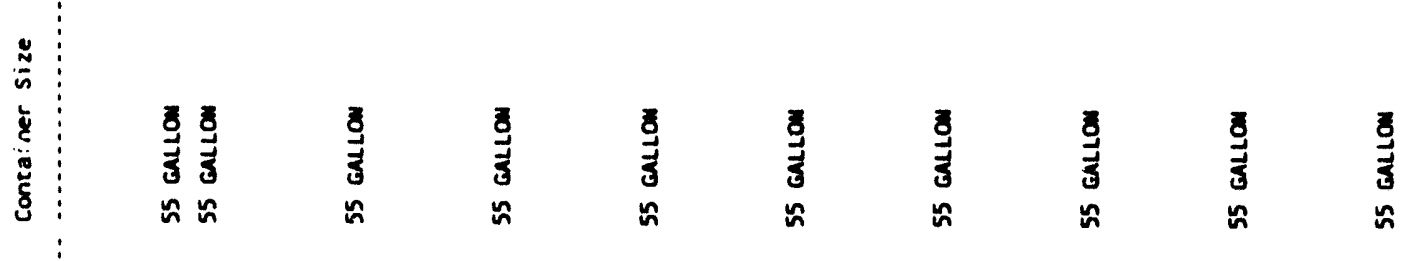

H.11:11111 


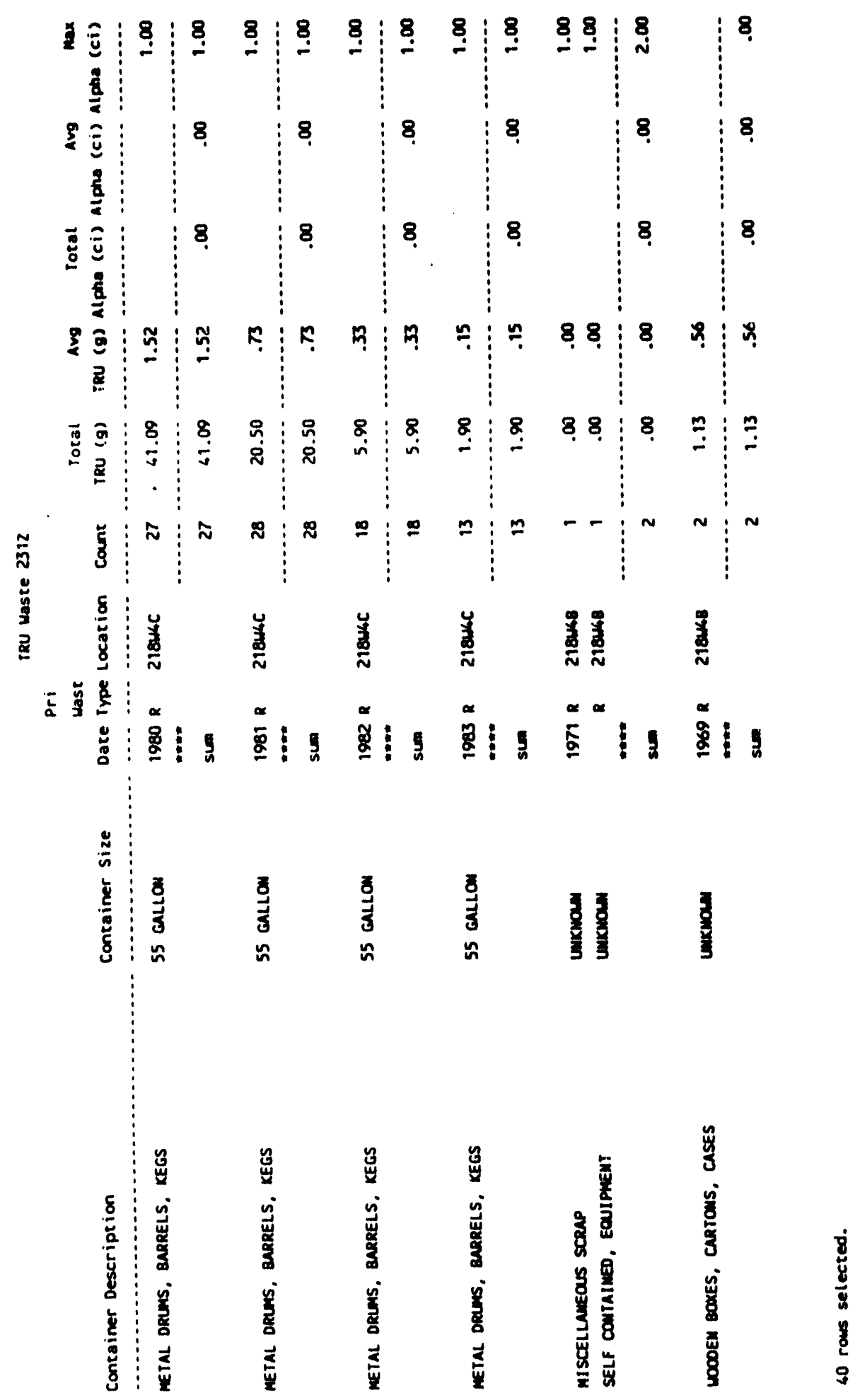


WHC-EP-0659

\author{
APPENDIX A.5
}

PHYSICAL CONTENTS DESCRIPTION FOR 231-Z B5-CALLON DRUMS CONTAINING TRU WASTE SORTED BY DATE, PRIMARY WASTE TYPE, AND STORAGE FACILITY 
WHC-EP-0659

This page intentionally left blank. 


\section{PHYSICAL CONTENTS DESCRIPTION FOR 231-2. 55-GALLON DRUMS CONTAINING TRU WASTE SORTED BY DATE, PRIMARY WASTE TYPE, AND STORAGE FACILITY}

This subappendix describes the physical contents of the 55-gal drums of TRU waste generated by Plutonium Metallurgy Laboratory (231-Z). Before 1978 physical contents were not required on the burial records, so a great many of the early records list the contents of the drum as "Miscellaneous".

The printout for this computer run sorts the contents data by storage facility, date, and primary waste type. The introduction to Appendix A contains a table of waste codes and their meanings. 


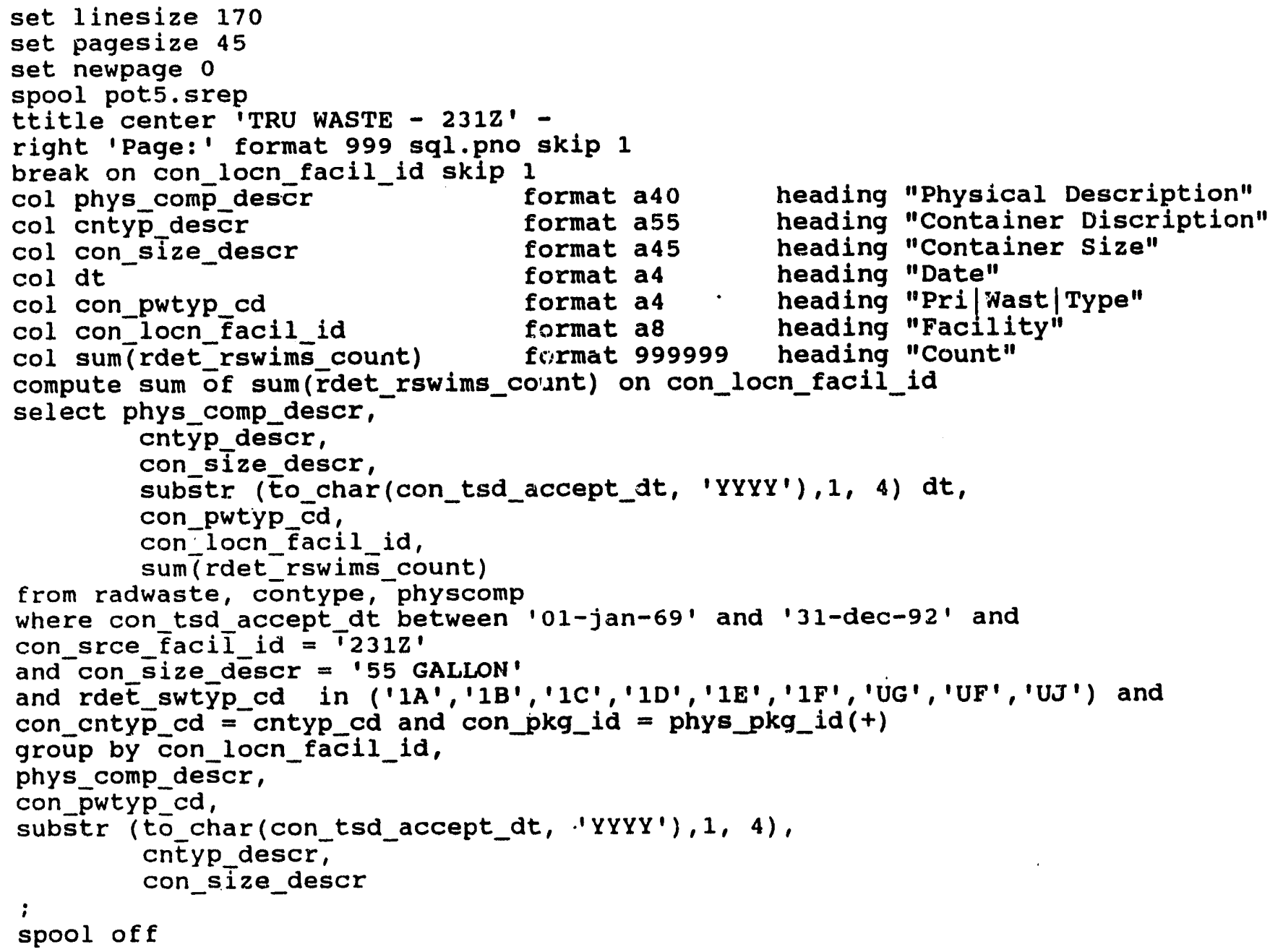




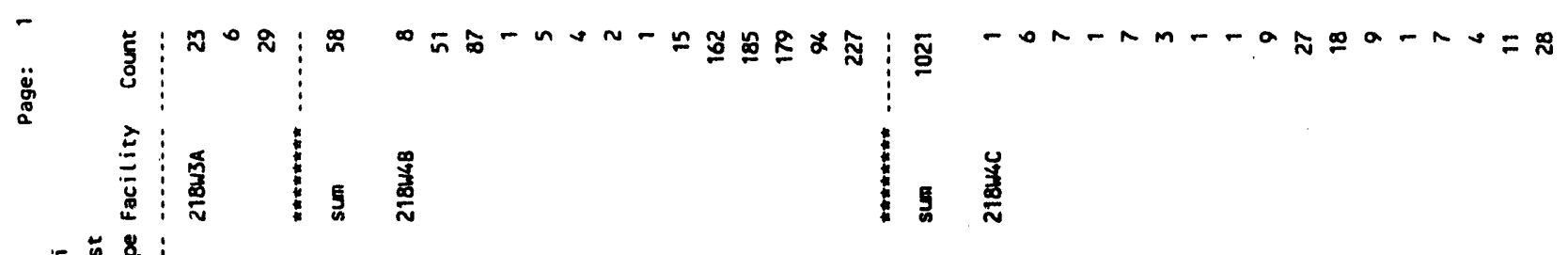

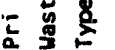

$2 \cos 2$

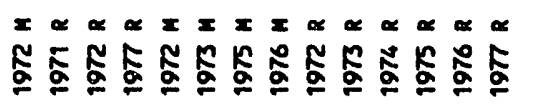

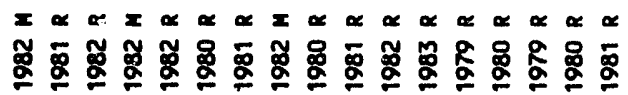
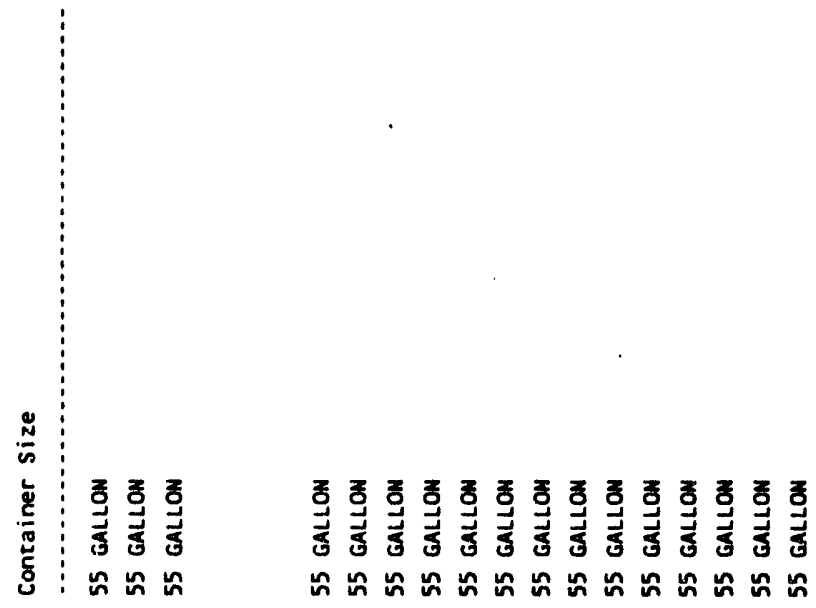

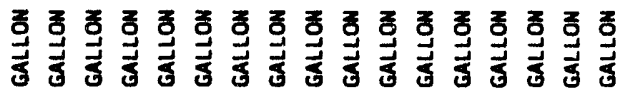

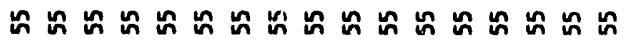

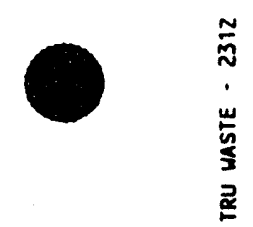

总总总

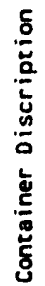

iे is

岃 $\underset{\sim}{\tilde{\alpha}} \underset{\alpha}{\alpha}$

面 面

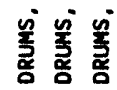

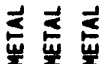

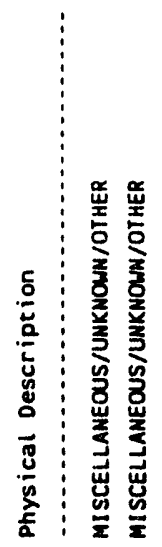

总总总总总总总总总总总总总总

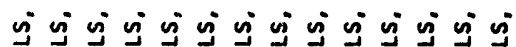

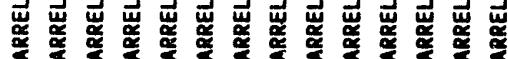

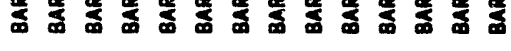

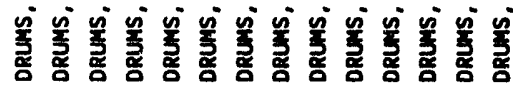

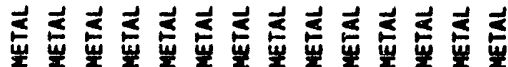

总总总总总总总总总总总总总总总总总

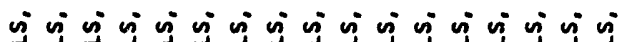

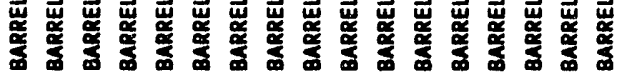

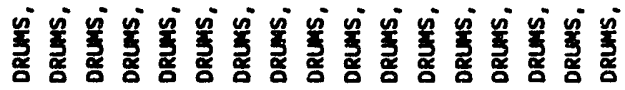

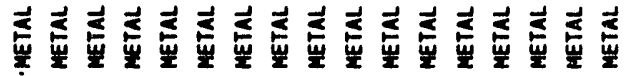

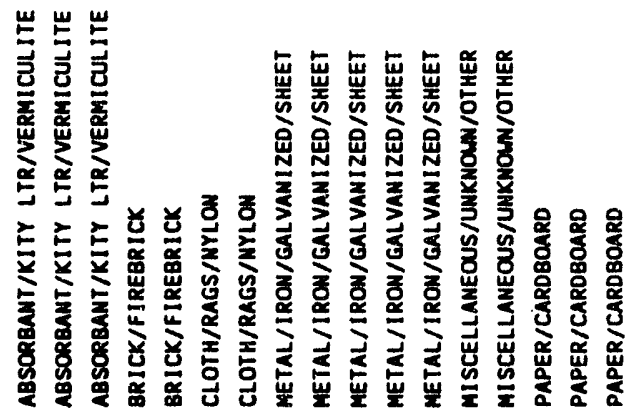


WHC-EP-0659

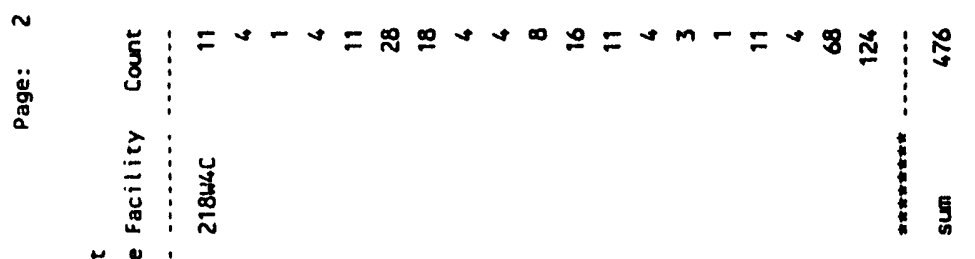

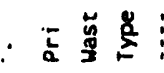

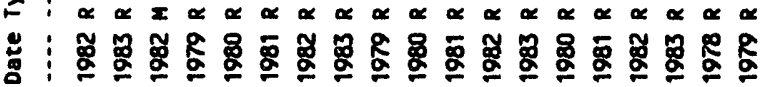

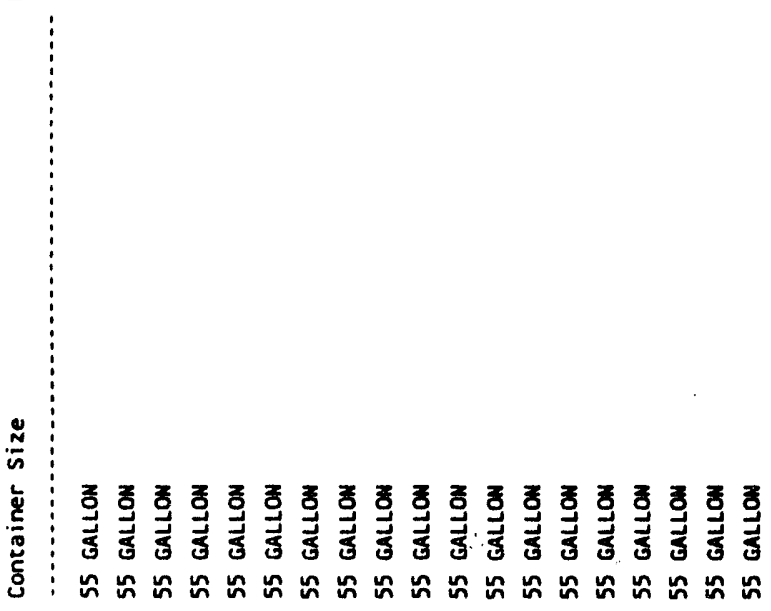

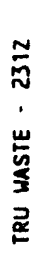

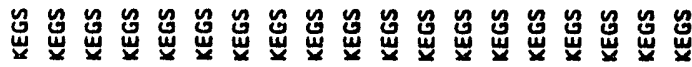

نे vे vं

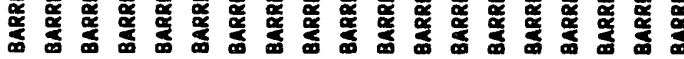

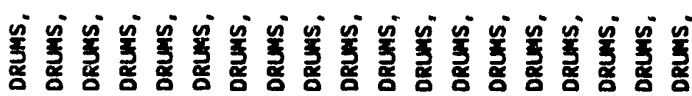

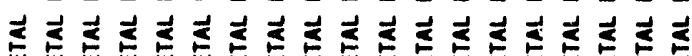

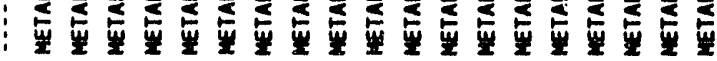

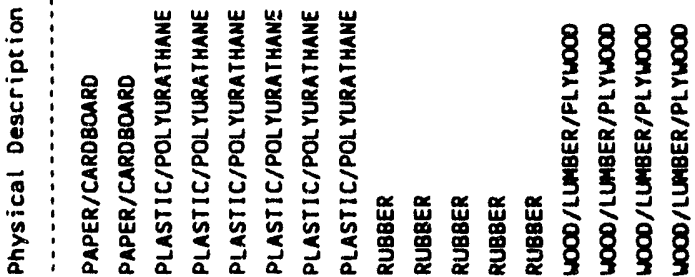


WHC-EP-0659

\section{APPENDIX A.6}

PHYSICAL CONTENTS DESCRIPTION FOR 231-Z TRU WASTE CONTAINERS OTHER THAN 55-GALLON DRUMS SORTED BY DATE, PRIMARY WASTE TYPE, AND STORAGE FACILITY 
WHC-EP-0659

This page intentionally left blank. 


\section{PHYSICAL CONTENTS DESCRIPTION FOR 231-Z TRU WASTE CONTAINERS OTHER THAN 55-GALLON DRUMS SORTED BY DATE, PRIMARY WASTE TYPE, AND STORAGE FACILITY}

This subappendix describes the physical contents of the TRU waste containers other than 55-gal drums generated at Plutonium Metallurgy Laboratory $(231-\mathrm{Z})$. Before 1978 physical contents were not required on the burial records, so a great many of the early records list the contents of the drum as "Miscellaneous".

The printout for this computer run sorts the contents data by storage facility, date, and primary waste type. The introduction to Appendix A contains a table of waste codes and their meanings. 


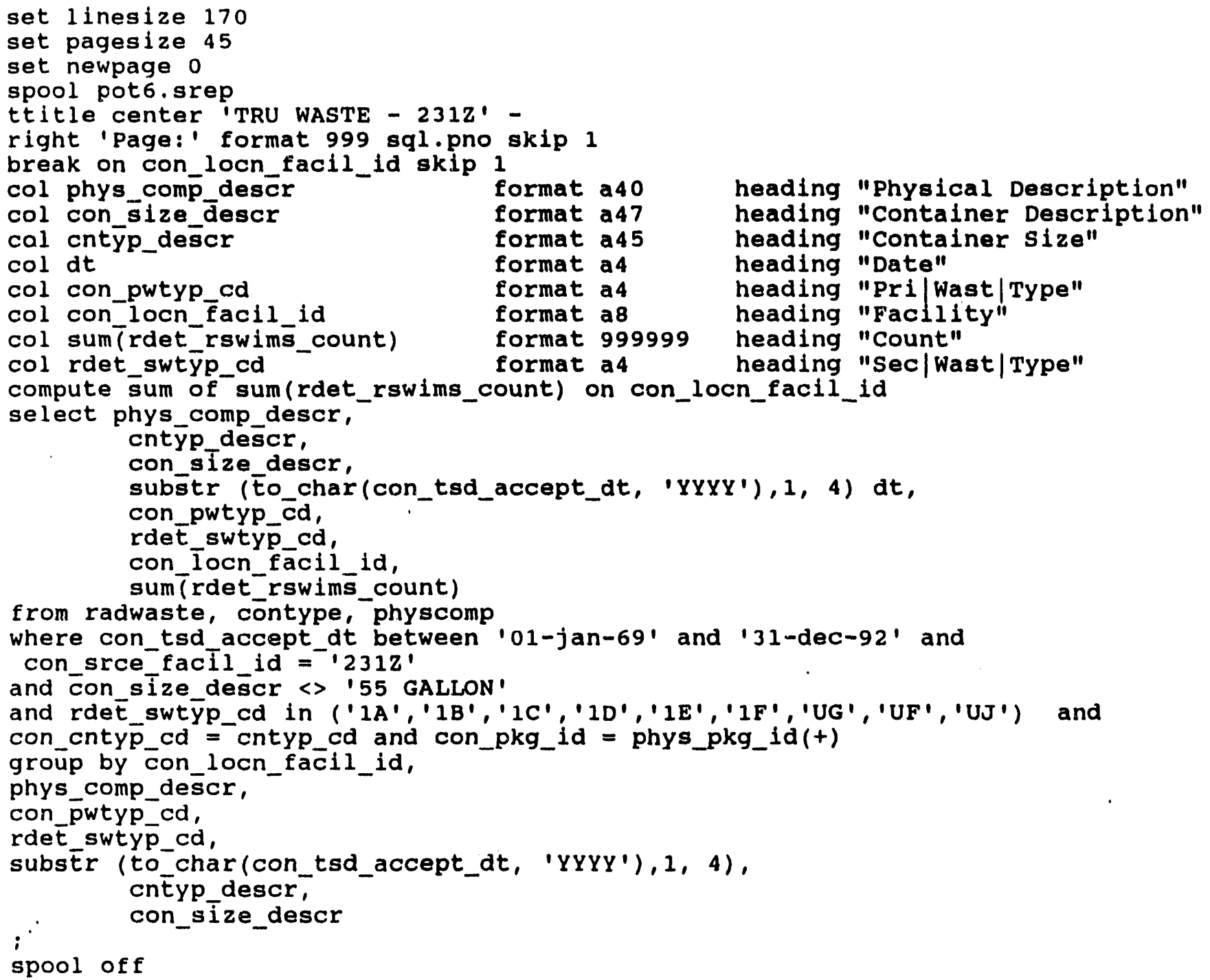


WHC-EP-0659

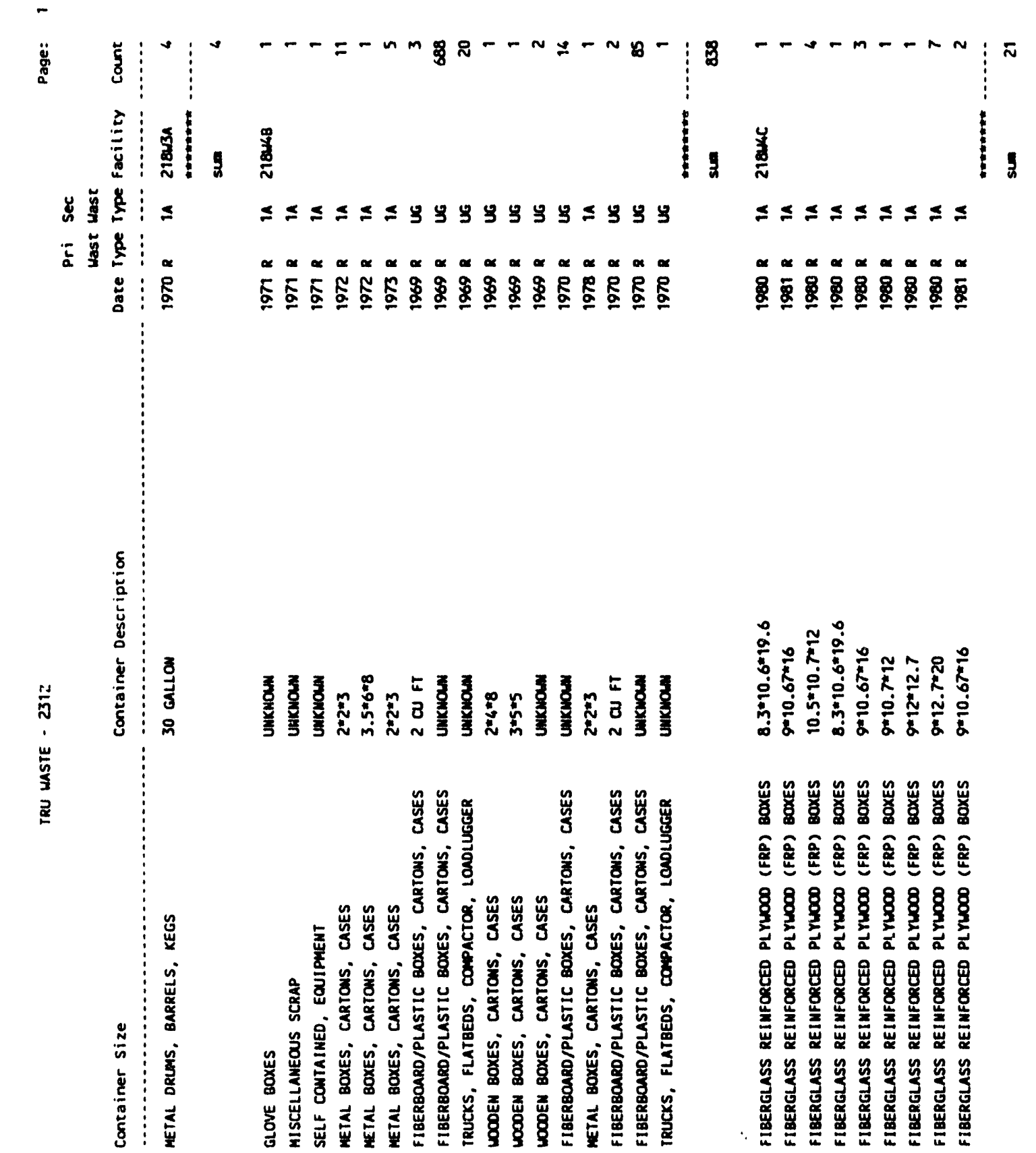

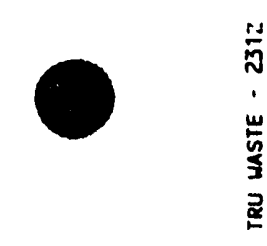

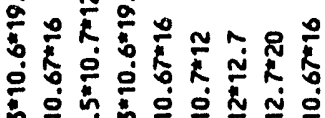

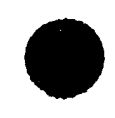

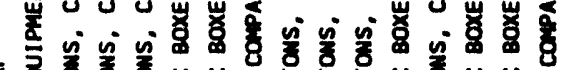

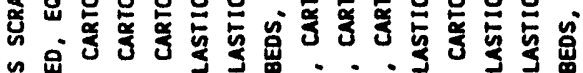

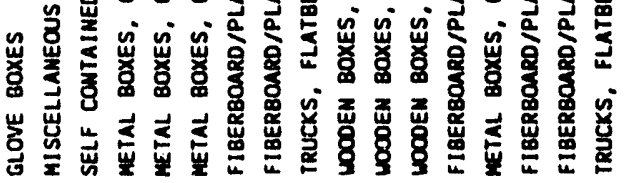
(m)

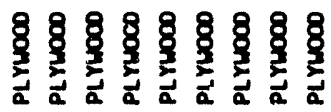

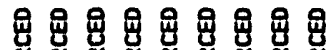
88888888

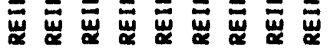

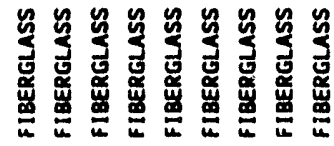
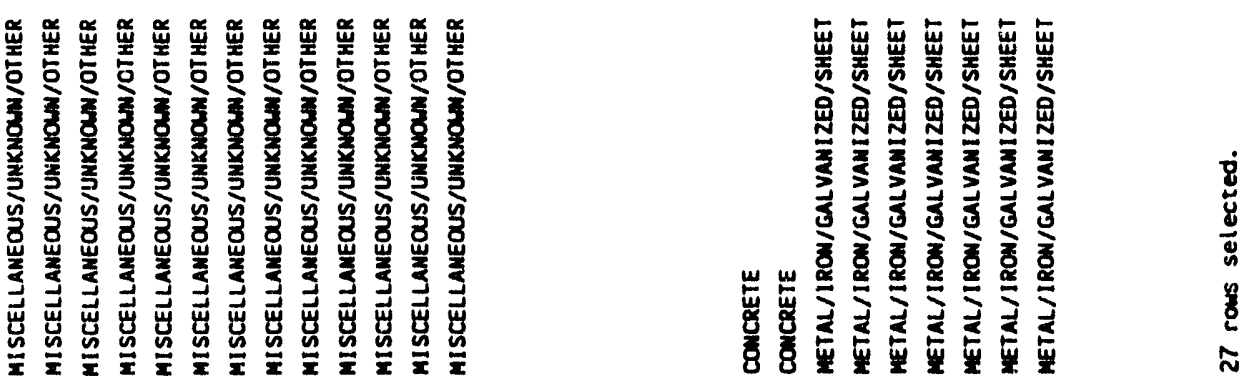
WHC-EP-0659

This page intentionally left blank. 
WHC-EP-0659

APPENDIX A.7

HAZARDOUS CONSTITUENTS OF 58-GALLON DRUMS CONTAININO TRU WASTE 
WHC-EP-0659

This page intentionally left blank. 


\section{HAZARDOUS CONSTITUENTS OF 55-CALLON DRUMS CONTAINING TRU WASTE}

The presence of hazardous constituents in a radioactive waste drum designates the waste as "Mixed" (primary waste code "M"). In this subappendix the hazardous contents of 55-gal drums generated at Plutonium Metallurgy Laboratory (231-Z) are sorted by storage facility.

Information concerning the hazardous constituents of waste containers was not required before 1986. During the R-SWIMS data re-entry program in the mid-1980's an attempt was made to add any available information on the hazardous materials present, however, this information was limited. 


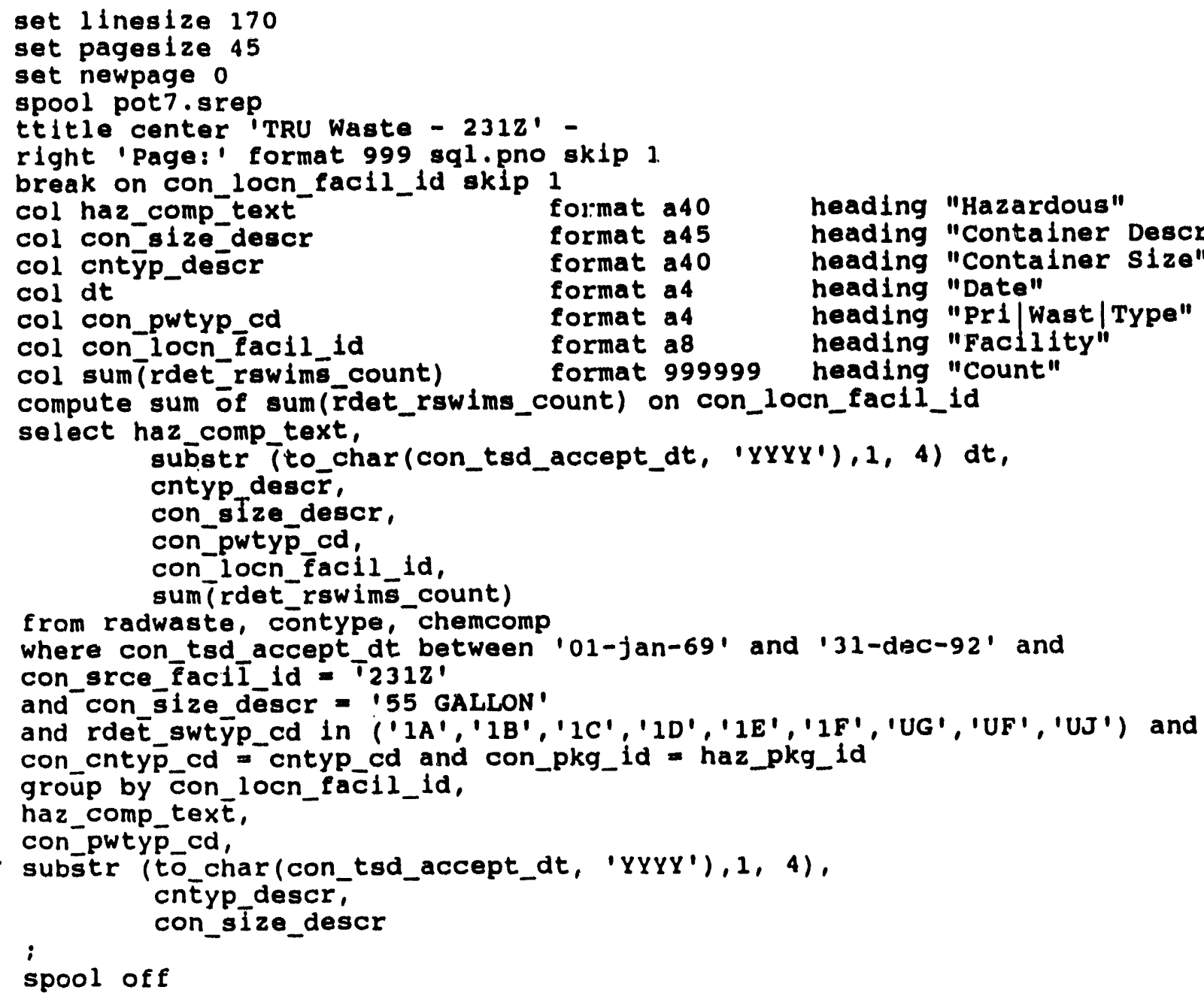


WHC-EP-0659

-

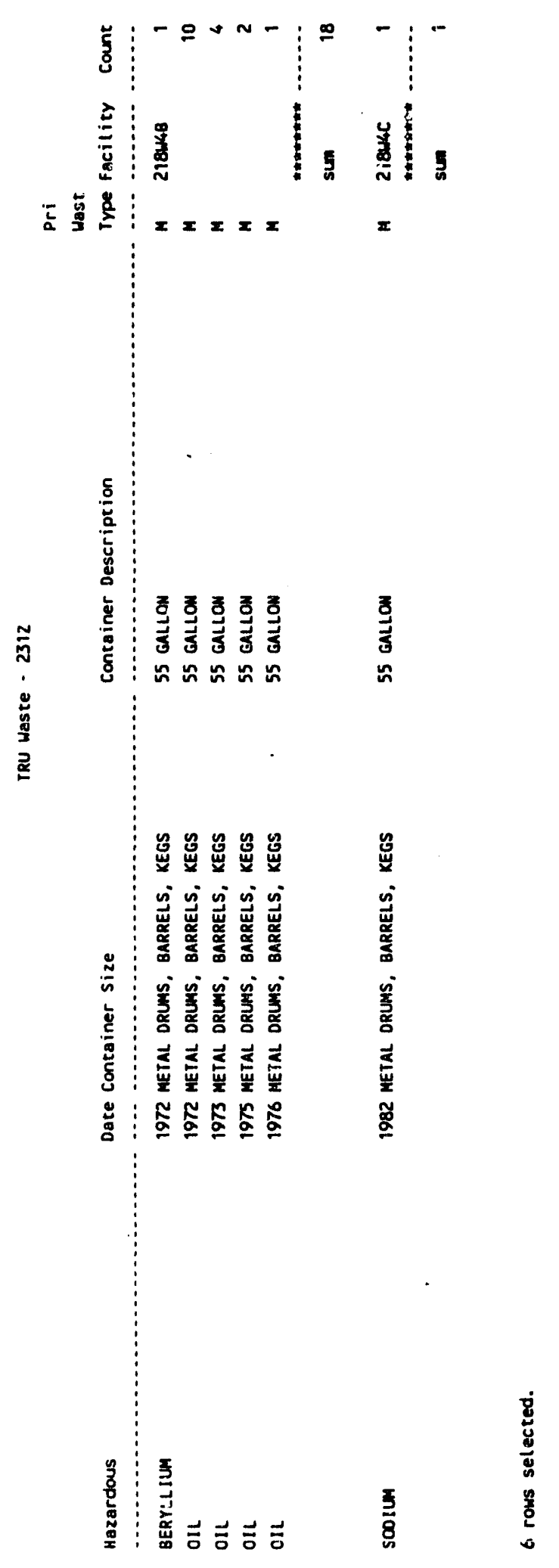


WHC-EP-0659

This page intentionally left blank. 
WHC-EP-0659

APPENDIX A.8

HAZARDOUS CONSTITUENTS OF TRU WASTE CONTAINERS OTHER THAN 55-GALLON DRUMS 
WHC-EP-0659

This page intentionally left blank.

\section{A-62}




\section{HAZARDOUS CONSTITUENTS OF TRU WASTE CONTAINERS OTHER THAN 55-GALLON DRUMS}

The presence of hazardous constituents in a radioactive waste drum designates the waste as "Mixed" (primary waste code " $\mathrm{M}^{\mathrm{N}}$ ). No hazardous constituents are listed in containers other than 55-gal drums generated at Plutonium Metallurgy Laboratory (231-Z); therefore this run did not reveal any hazardous information. 


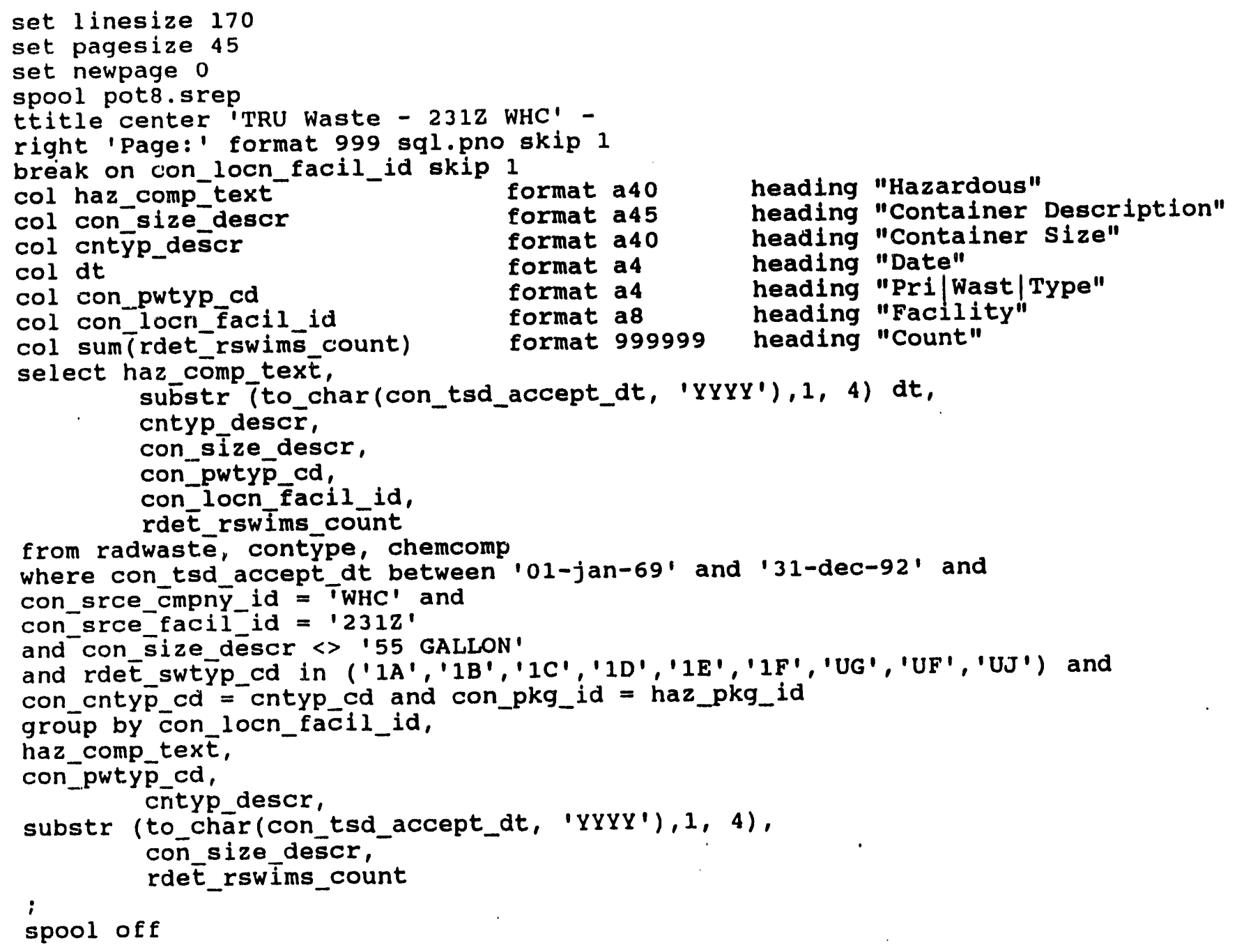




\section{WHC-EP-0659}

col con_pwtyp_cd

col con locn facil id

format a4

format as

heading "Pri|Wast|Type"

col sum(rdet_rswims_count)

format 999999

heading "Facility"

select haz comp tex $\bar{t}$,

substr (to_char(con_tsd_accept_dt, 'YYYY'), 1, 4) $d t$, cntyp descr,

con_size_descr,

con_pwtyp_cd,

con locn facil id, rdét_rswims count

from radwaste, contype, chemcomp

where con tsd accept dt between' $01-j a n-69$ ' and '31-dec-92' and

con_srce_cmpny $\bar{y}_{\text {id }}=$ ' $\mathrm{WHC}$ ' and

con srce facilid $=' 231 \mathrm{Z}^{\prime}$

and con size descr 255 GALLON'

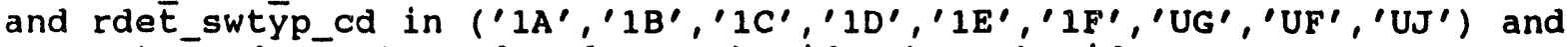
con_cntyp_cd = cntyp_cd and con_pkg_id = haz_pkg_id

"pot̄8.sql" 37 lines, 1184 characters

SQL> Qpot8

no rows selected

SQL>

$\circ \circ \circ$

'VT100॰ 80 COL" 7 BIT MODE" 
WHC-EP-0659

This page intentionally left blank. 
WHC-EP-0659

APPENDIX A.9

ISOTOPES LISTED IN 55-GALLON DRUMS CONTAINING TRU WASTES 


\section{WHC-EP-0659}

This page intentionally left blank. 


\section{ISOTOPES LISTED IN EE-GALLON DRUMS CONTAINING TRU WASTES}

This subappendix contains a listing of the SWITS isotope information for TRU waste from Plutonium Metallurgy Laboratory $(231-Z)$ stored in 55-gal drums. The isotope field in SWITS contains several types of information including the following:

- Specific isotope (e.9., ${ }^{241} \mathrm{Am},{ }^{237} \mathrm{~Np},{ }^{233} \mathrm{U}$, and $\left.{ }^{230} \mathrm{Pu}\right)$

- Generic isotope listings (e.g., plutonium, uranium-enriched, and uraniumdepleted)

- ${ }^{230} \mathrm{Pu}$ fissile gram equivalents (230 PU FSL GR equivalent).

- Total alpha

- Total beta/gamma.

This computer run contains the isotope field listing along with the number of TRU waste drums with that listing. The run is sorted by storage facility and year. 


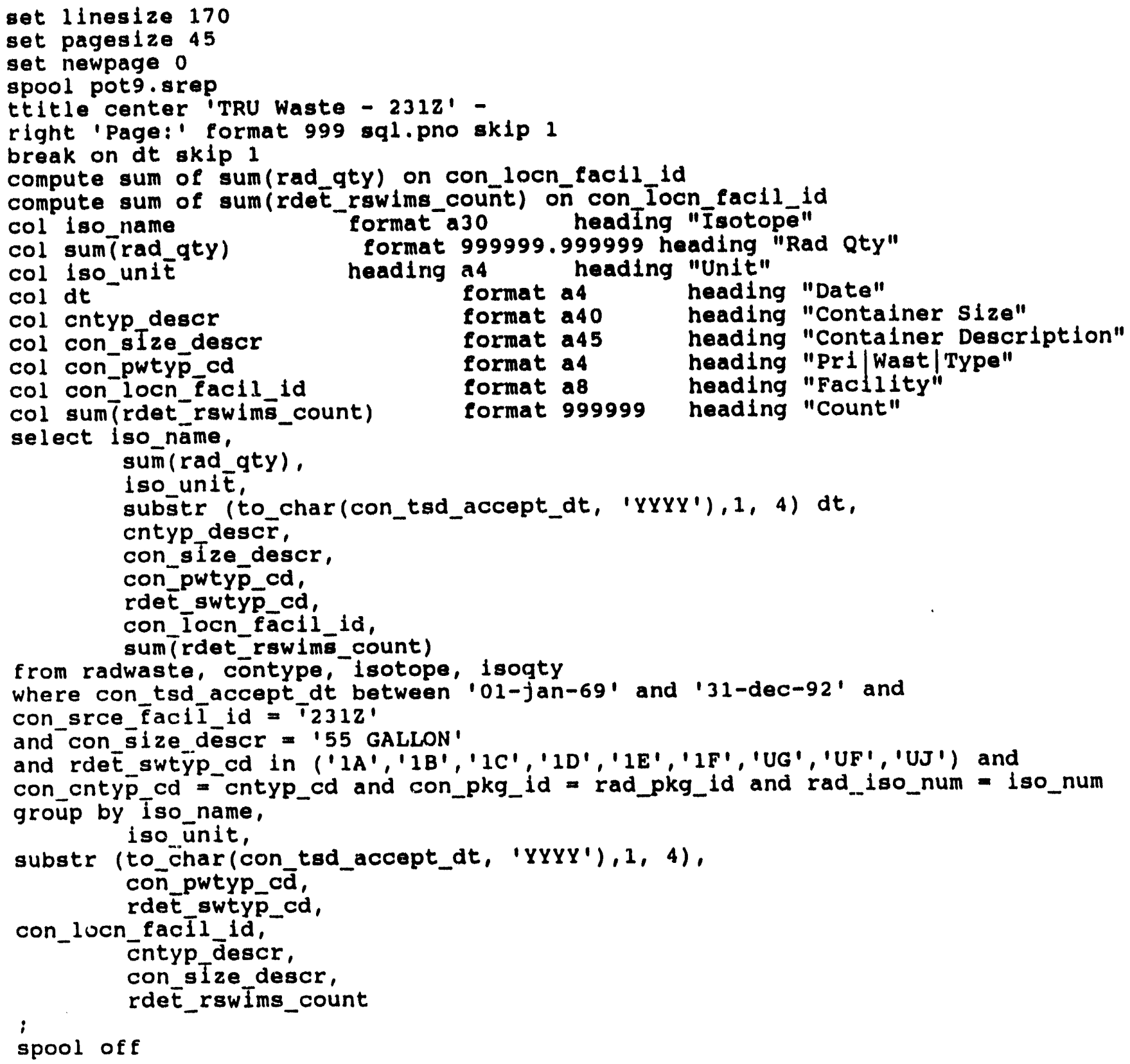


WHC-EP-0659

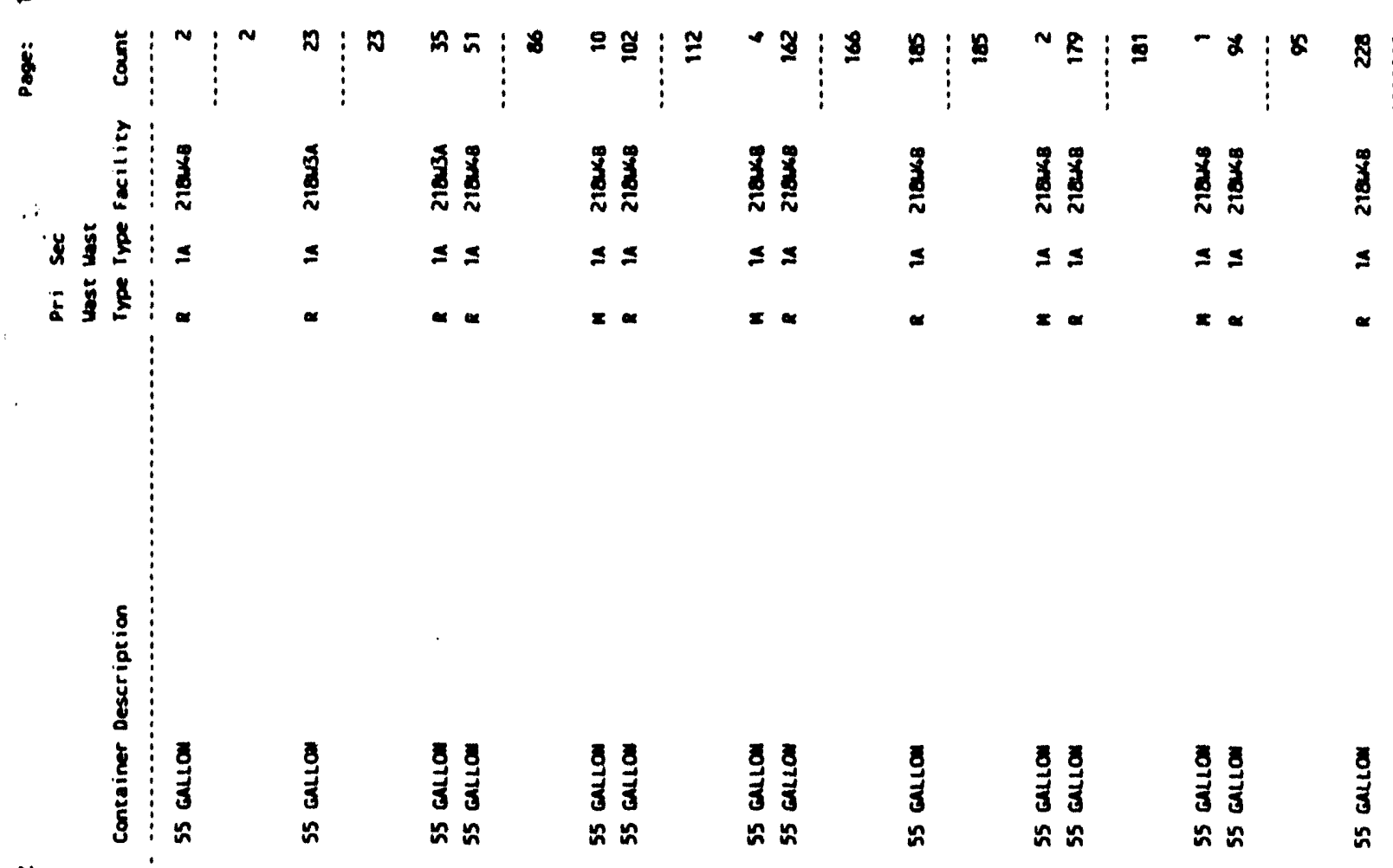

$\tilde{7}$
$\vdots$
0
$z$
$z$

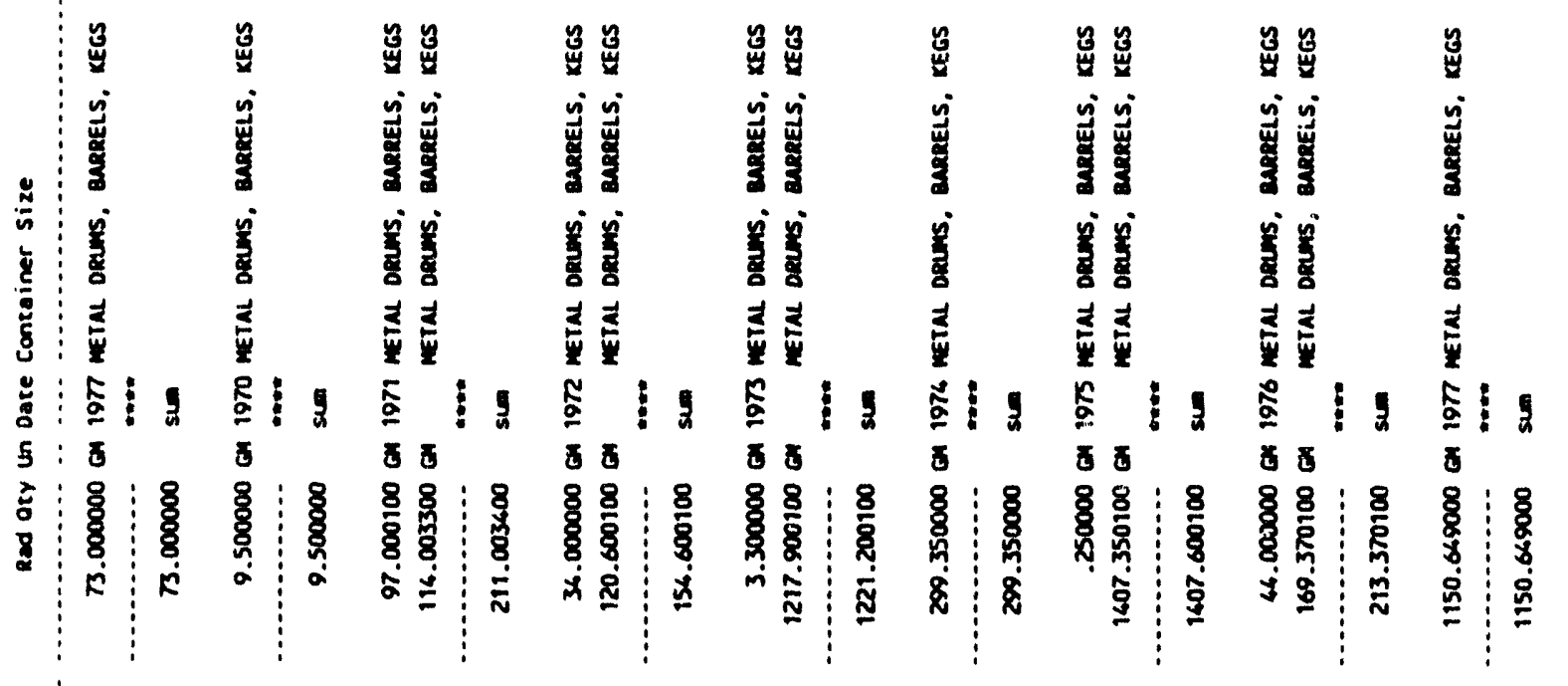

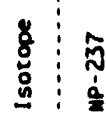

$\vec{a} \quad \vec{a} z \quad z \vec{a}$

$\vec{z} \mathbf{z} \quad \vec{z}$

$\vec{a} \mathbf{a}$

a 2

z 


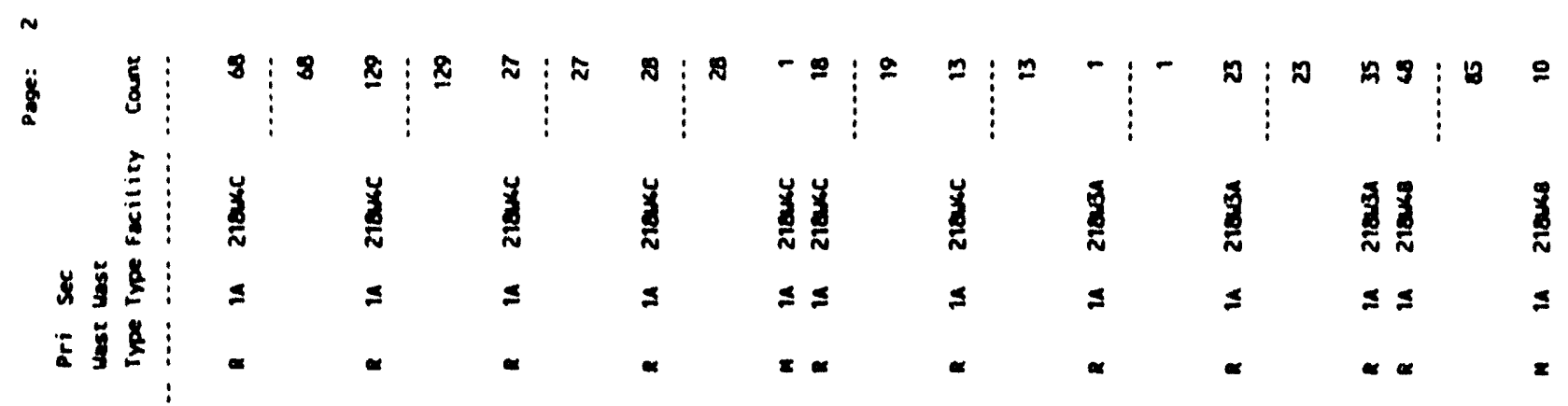

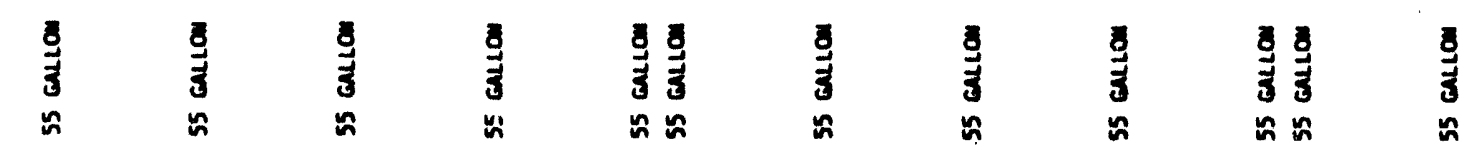

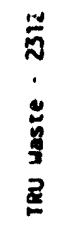

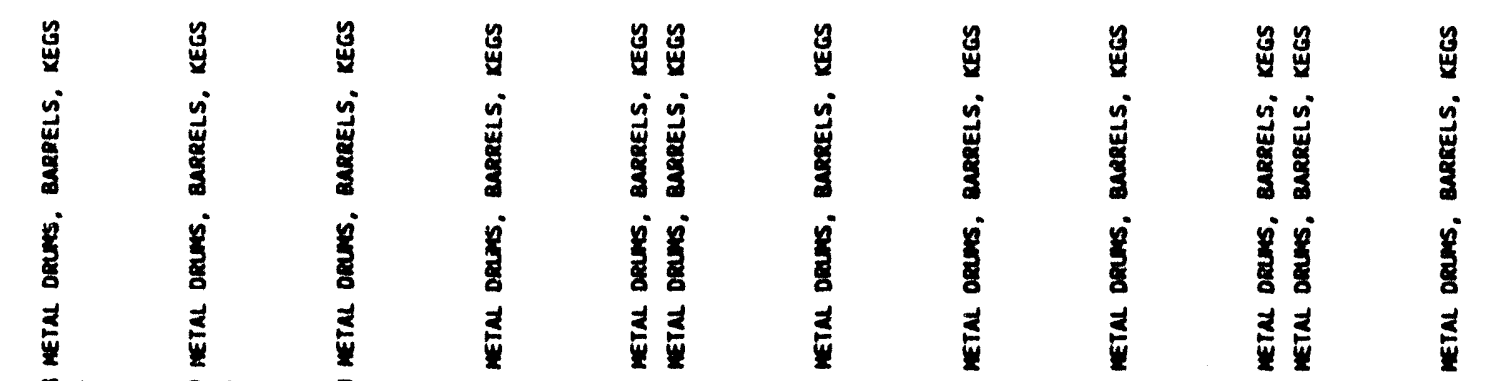

苟

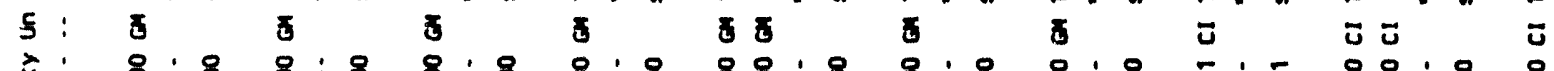

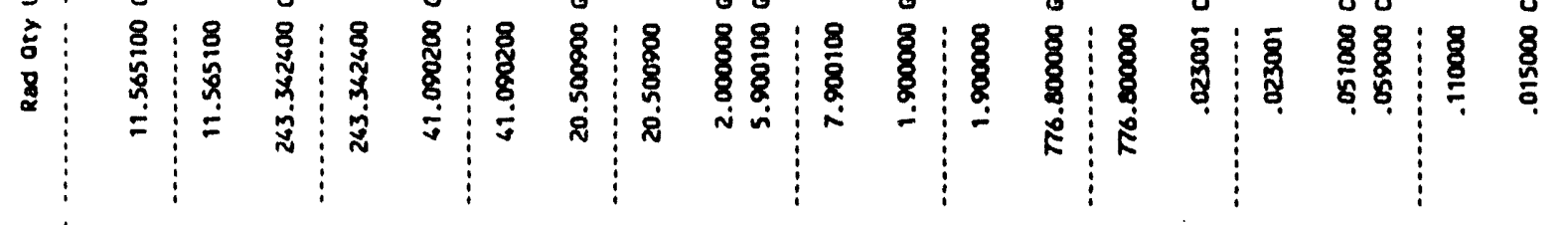

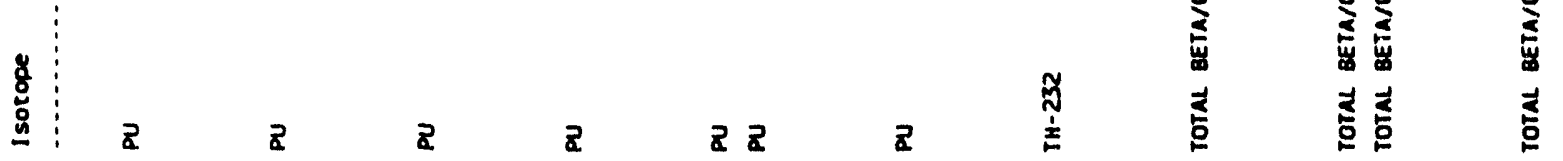


WHC-EP-0659

0

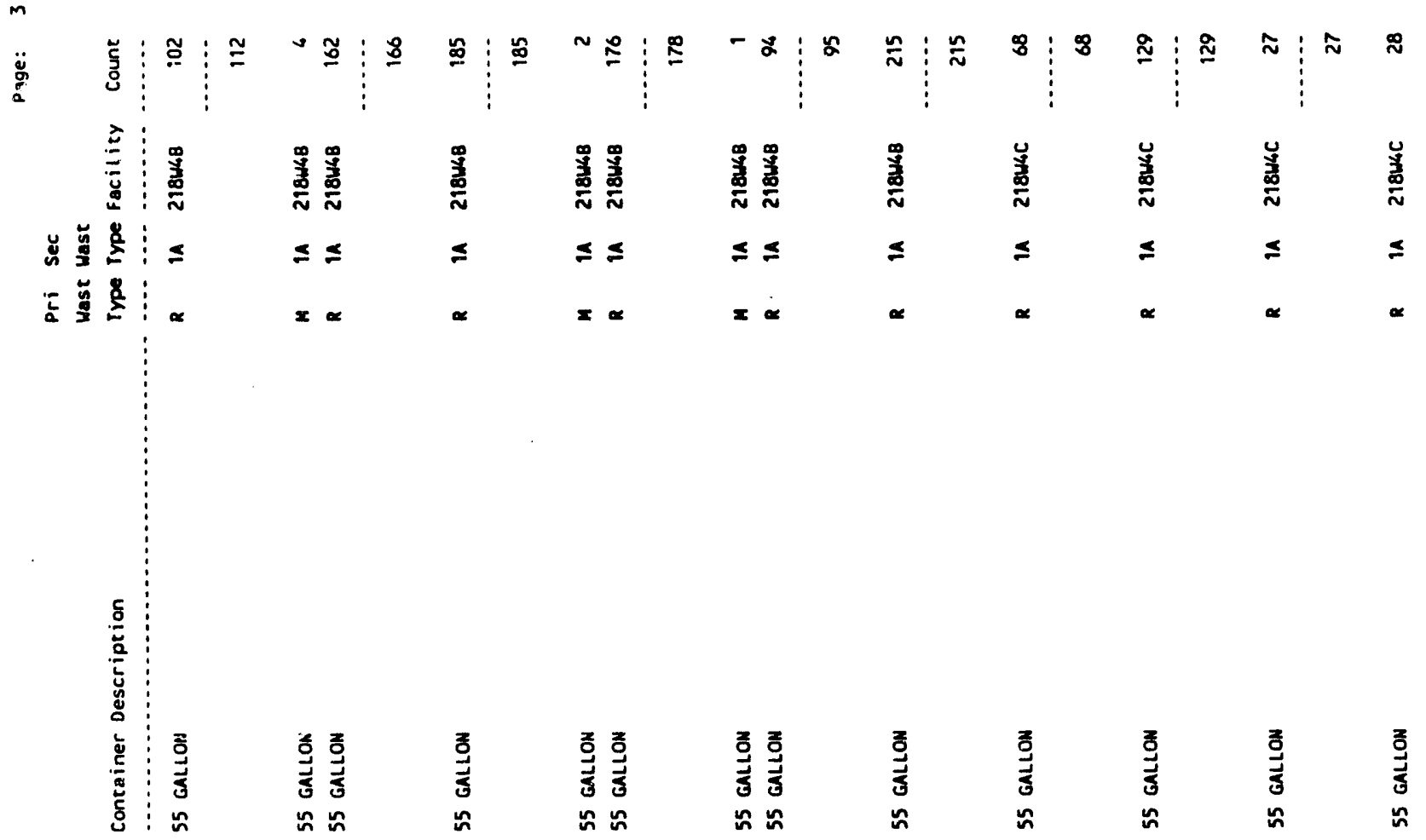

-

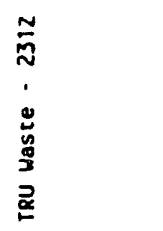

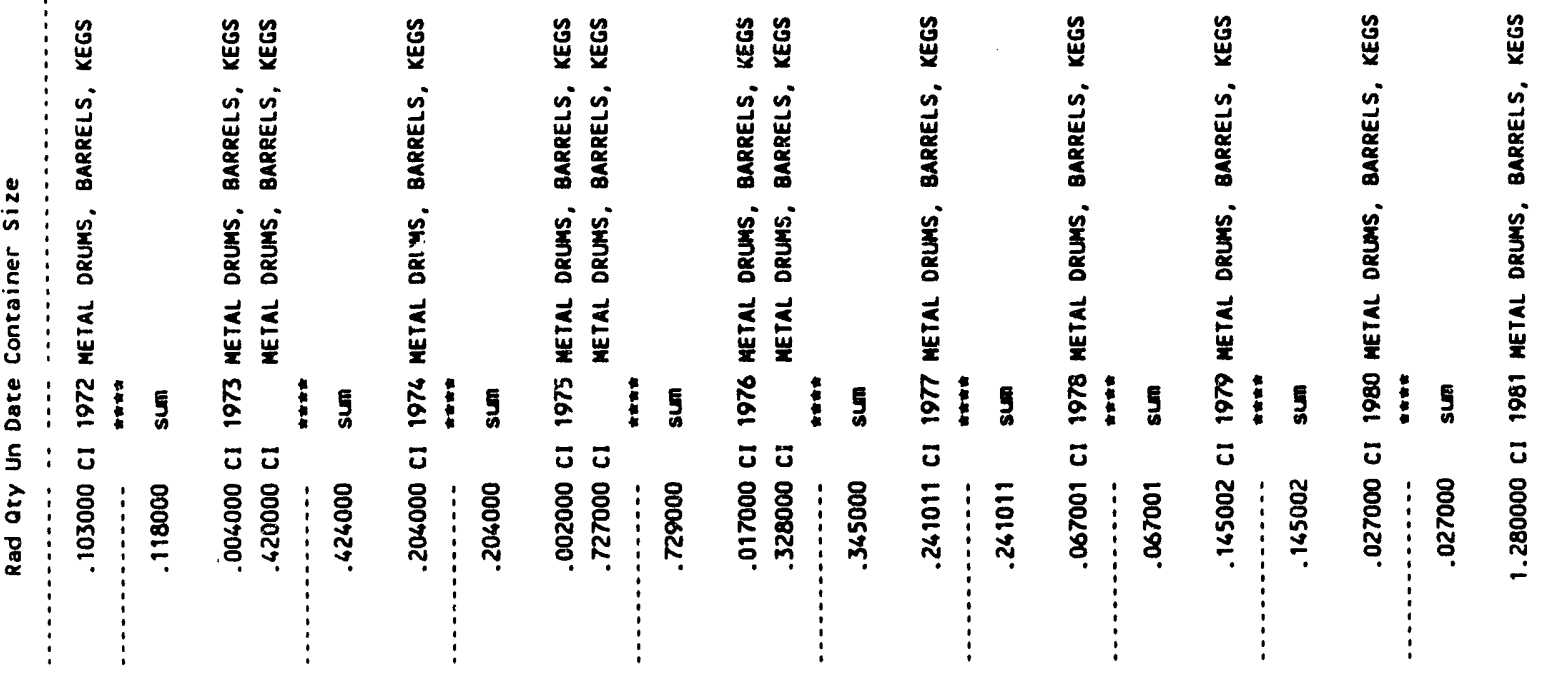

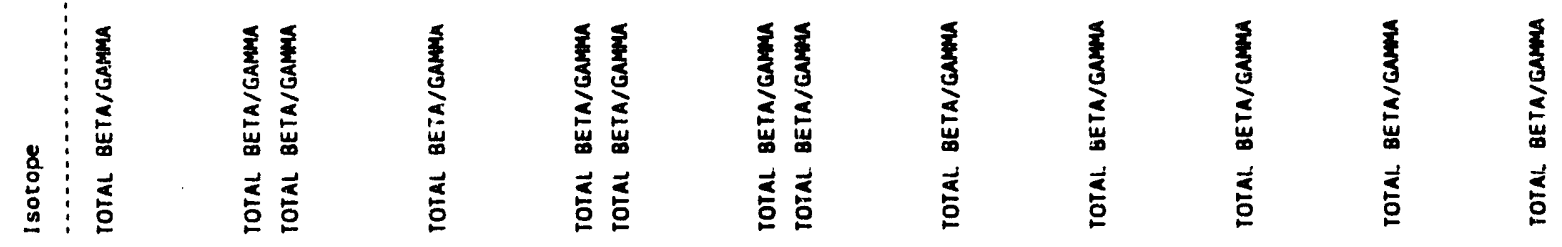


WHC-EP-0659

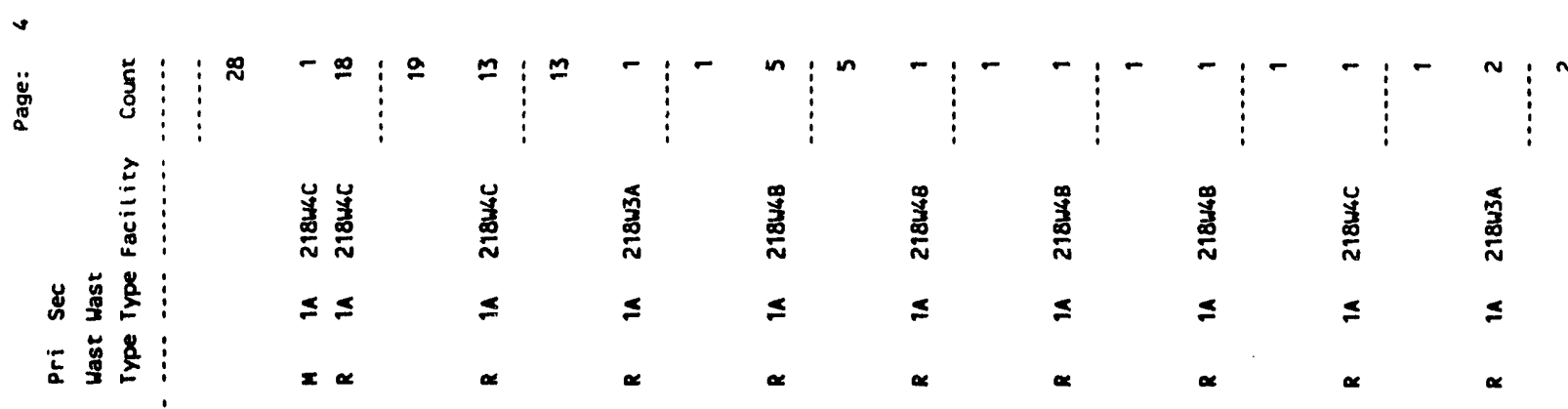

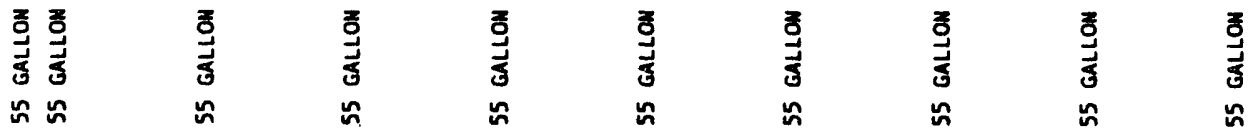

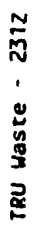

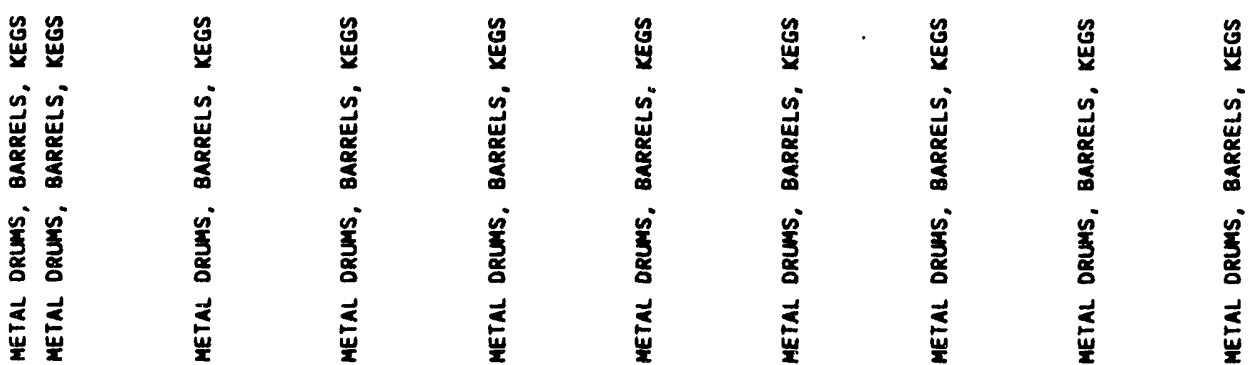

总

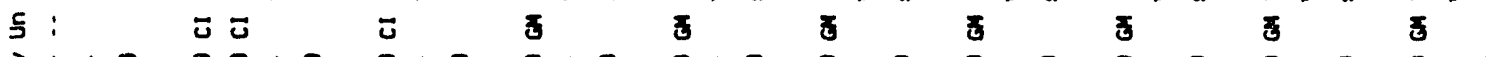

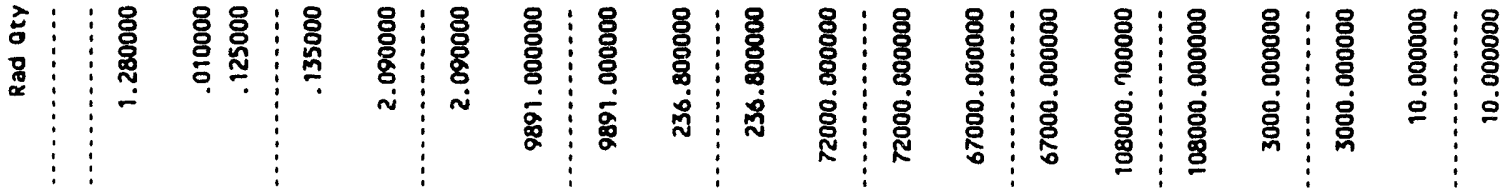

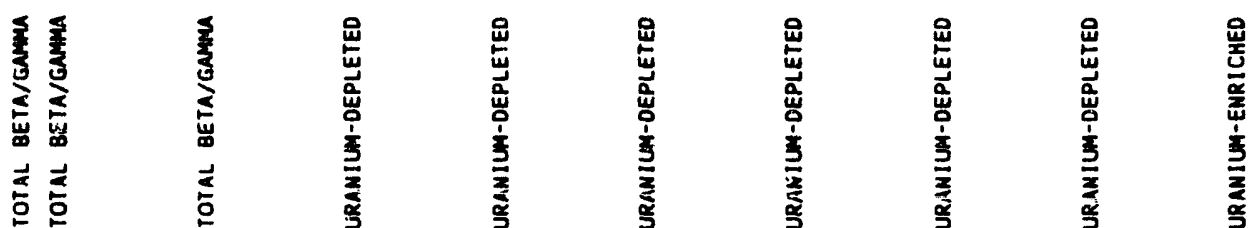

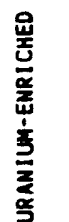


WHC-EP-0659

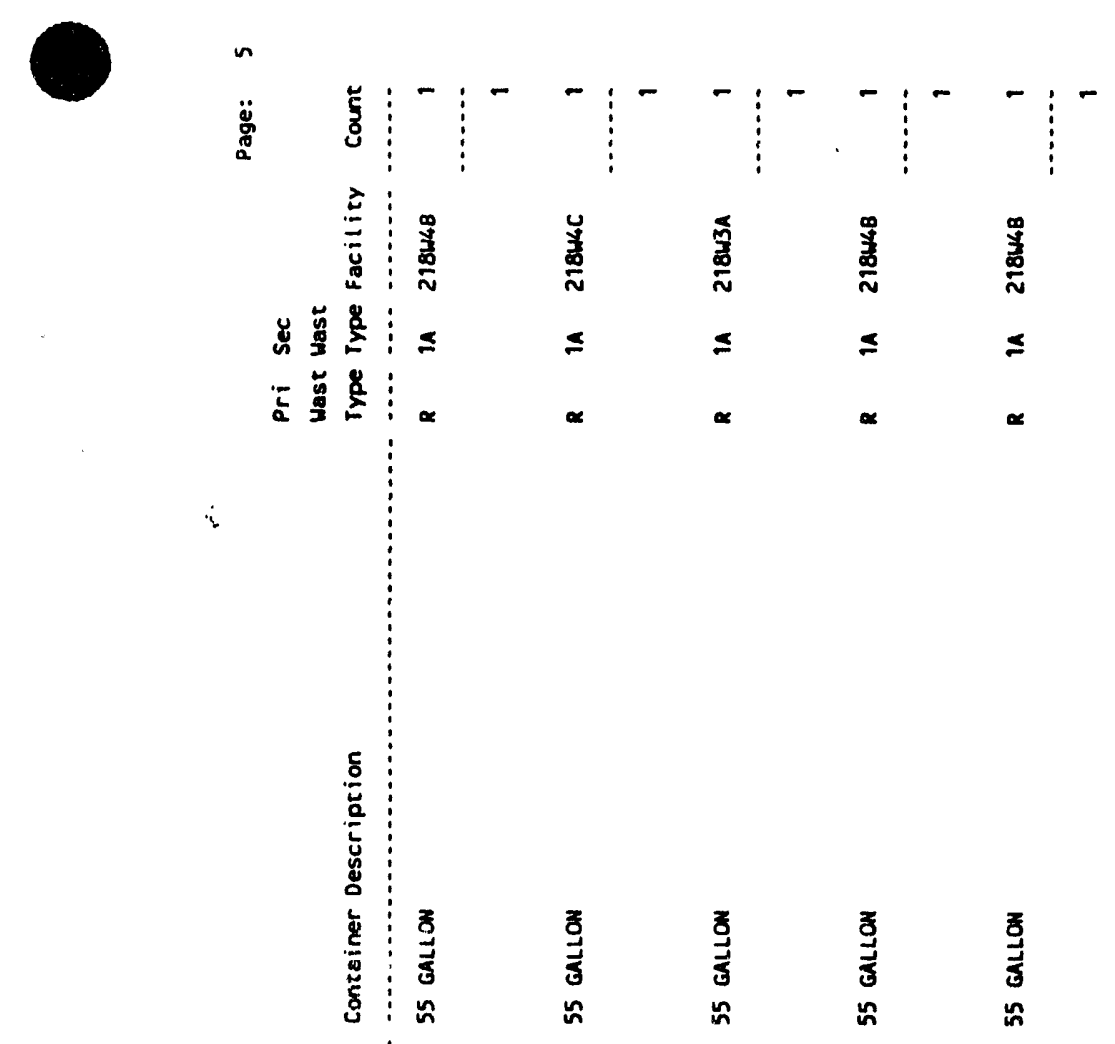

-

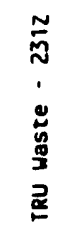

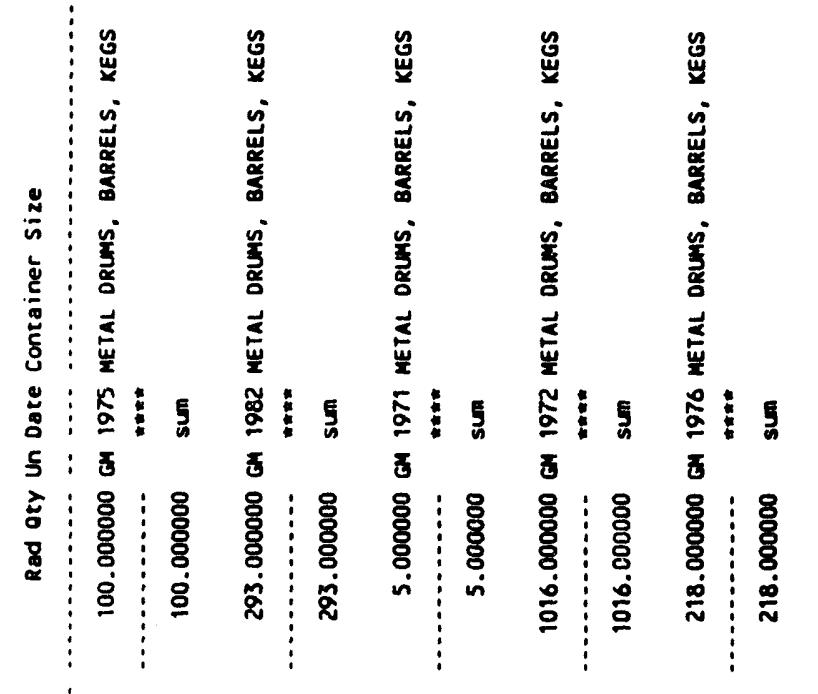

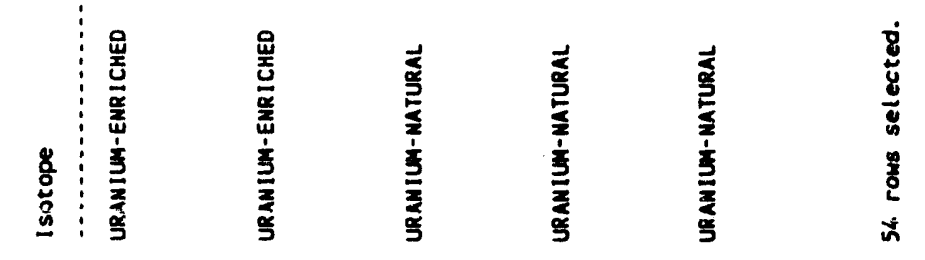


WHC-EP-0659

This page intentionally left blank. 
WHC-EP-0659

APPENDIX A.10

ISOTOPES LISTED IN TRU CONTAINERS OTHER THAN 55-GALLON DRUMS 
WHC-EP-0659

This page intentionally left blank. 


\section{ISOTOPES LISTED IN TRU CONTAINERS \\ OTHER THAN 55-GALLON DRUMS}

This subappendix contains a listing of the SWITS isotope information for TRU waste from Plutonium Metallurgy Laboratory (231-Z) stored in containers other than 55-gal drums. The isotope field in SWITS contains several types of information including the following:

- Specific isotope (e.g., ${ }^{241} \mathrm{Am},{ }^{237} \mathrm{~Np},{ }^{233} \mathrm{U}$, and $\left.{ }^{238} \mathrm{Pu}\right)$

- Generic isotope listings (e.g., plutonium, uranium-enriched, uranium-depleted)

- ${ }^{230} \mathrm{Pu}$ equivalent curies (PE-CI)

- Total alpha radionuclide content

- Total beta/gamma radionuclide content

- Plutonium equivalent curies (PE-Ci).

This computer run contains the isotope field listing along with the number of TRU waste containers with that listing. The run is sorted by storage facility and year. 


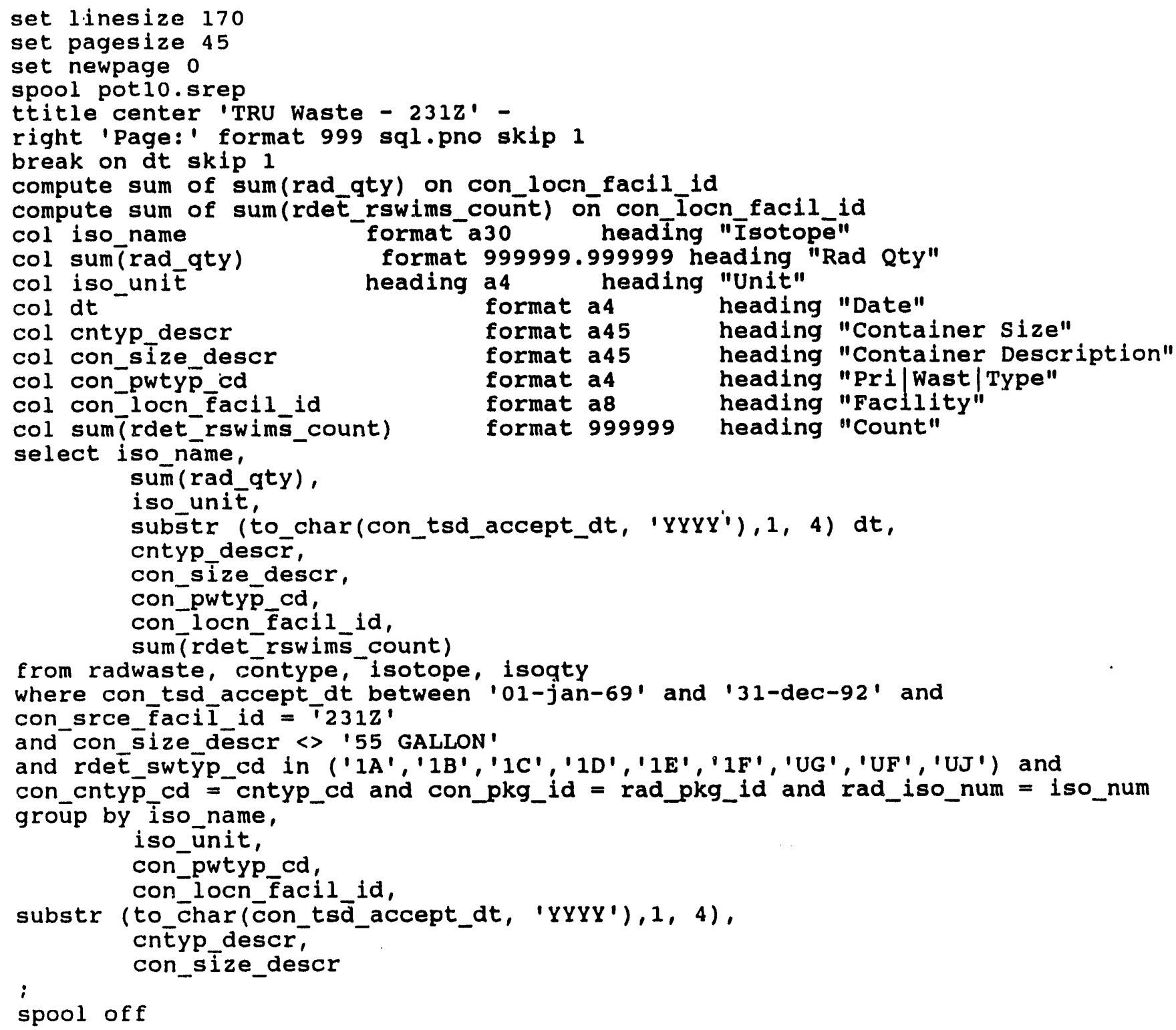


$\bullet$

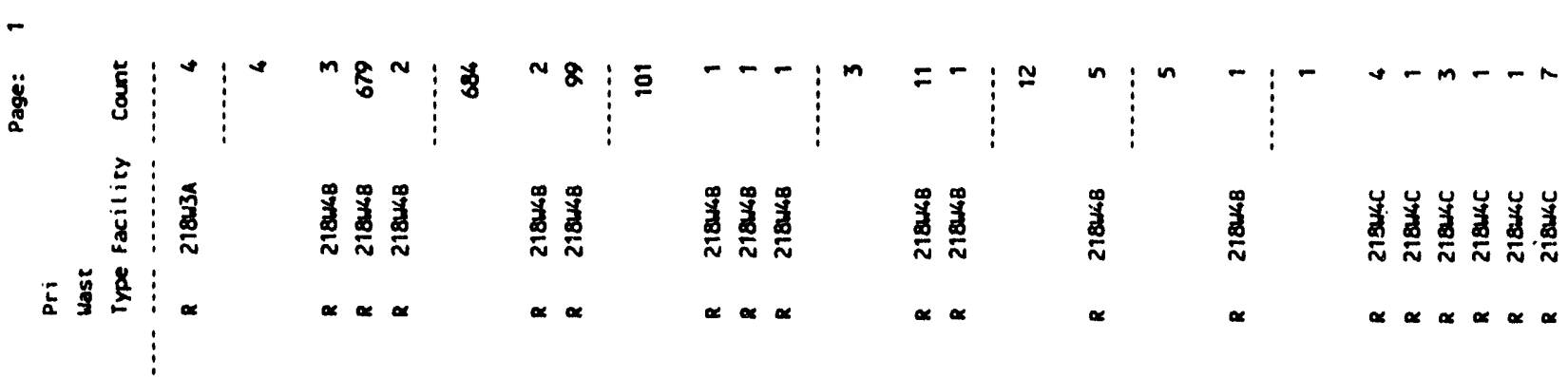

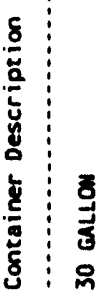

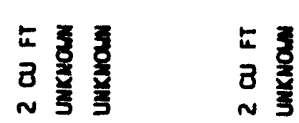

III

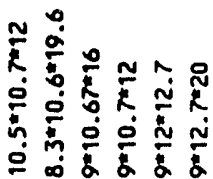

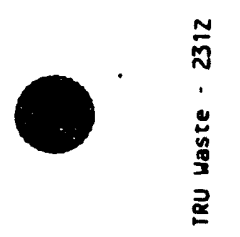

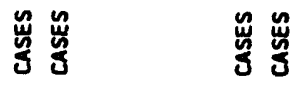

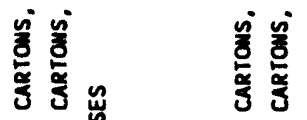

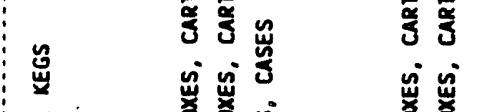

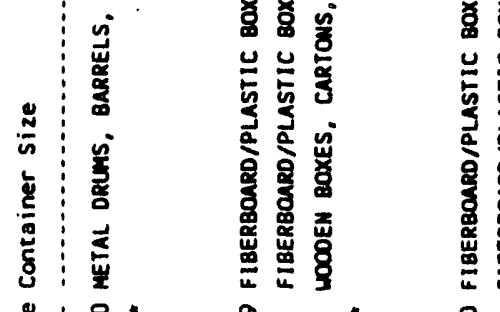

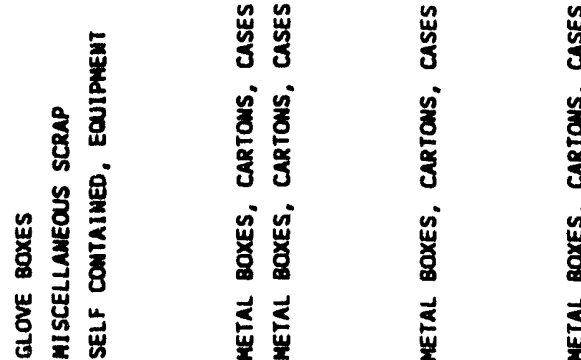

苛

s:

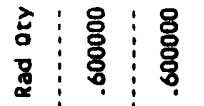

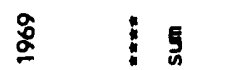

蛋

잉

实

졿 万ٓ

उ

万ᄌ

ฐ

是

恣

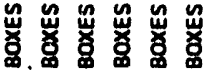

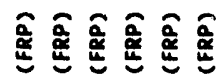

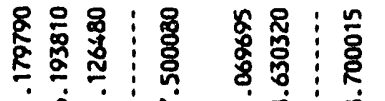

8.

条 :

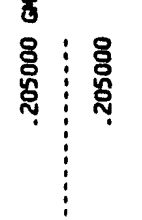

岁

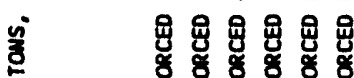

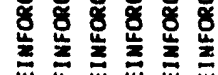

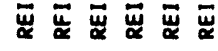

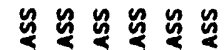

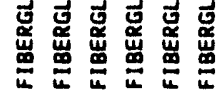

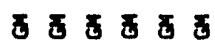

8

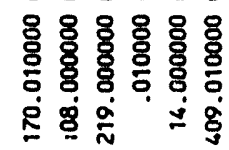

$\because$

$\begin{array}{l:l}8 & \\ 8 & \\ 0 & 2\end{array}$

दू द इ

द

z ฉ z

ฉ ฉ

$\mathbf{z}$

z

ฉ る る る る a 
WHC-EP-0659

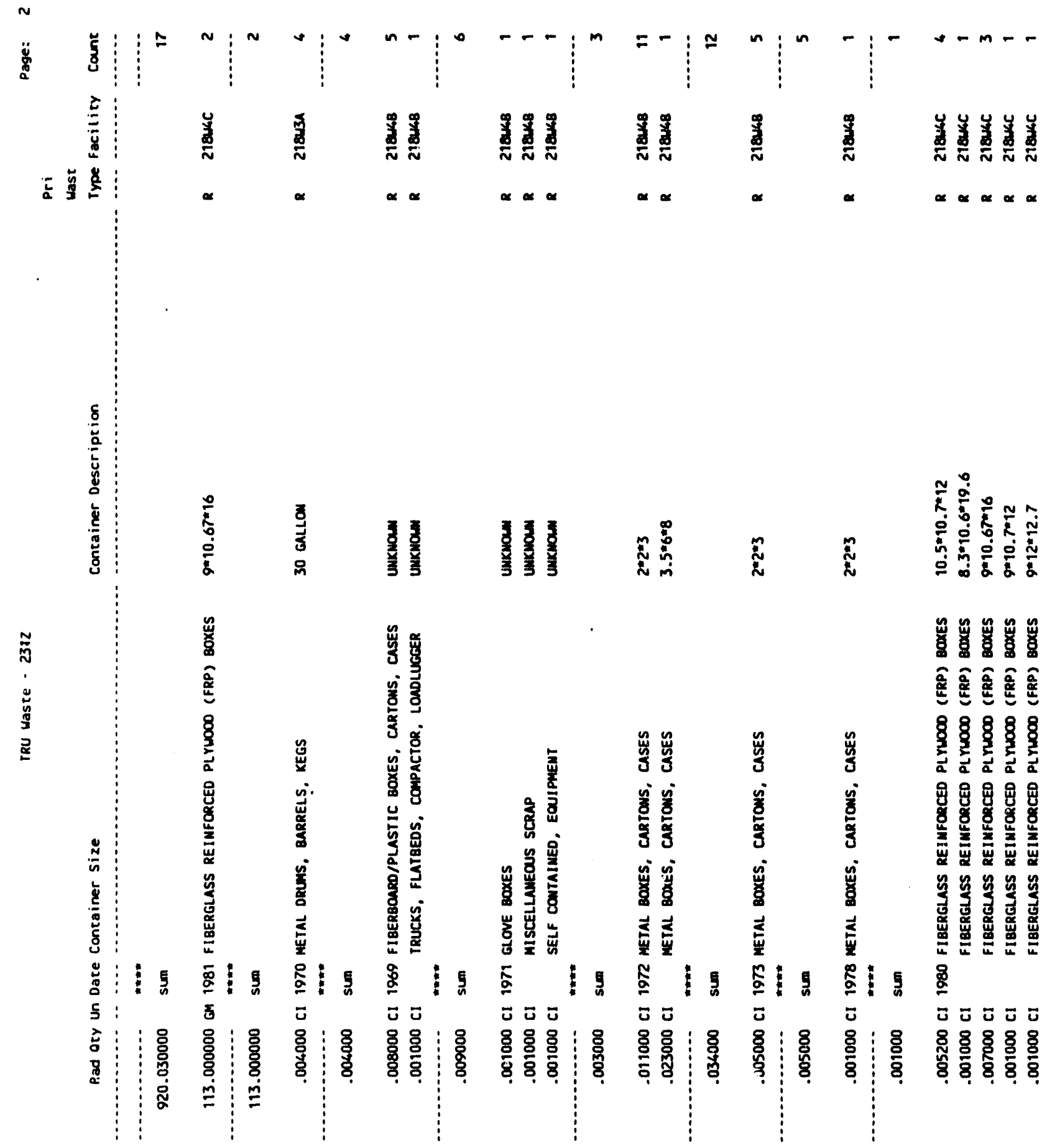


WHC-EP-0659
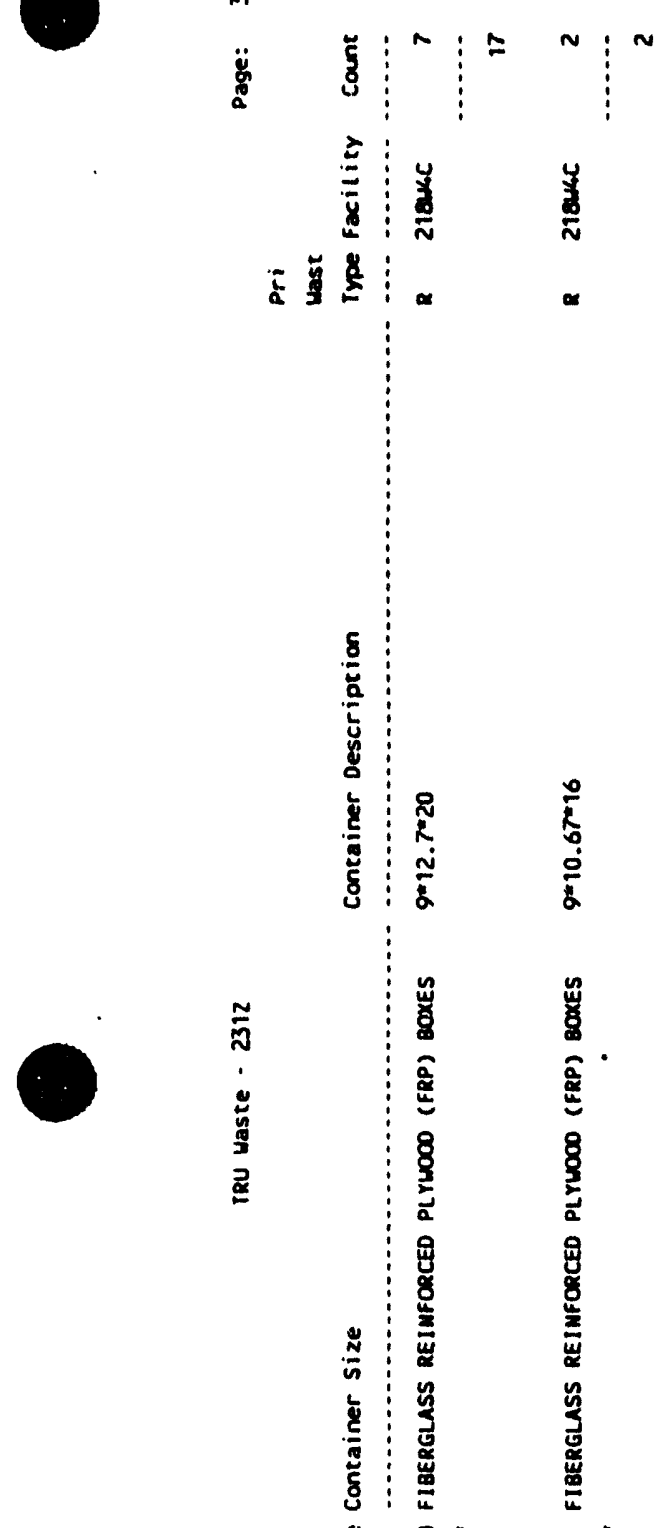

艾:

ร: $匚$ उ

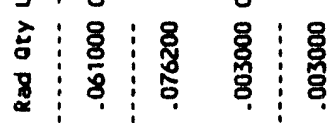

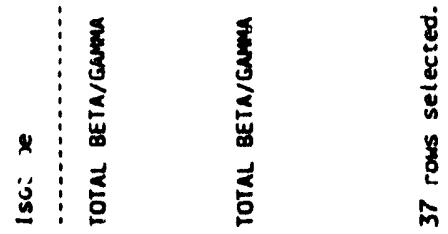


WHC-EP-0689

This page intentionally left blank.

\section{A-84}




\section{DISTRIBUTION}

Number of copies

OFFSITE

2

Los Alamos Technical Associates 8633 Gage Blvd.

Kennewick, Washington 99336

J. Pottmeyer (2)

\section{ONSITE}

4

U.S. Department of EnerayRichland Field Office

R. M. Gordon

R3-80

R. F. Guercia (2)

A5-21

Public Reading Room

A1-65

Westinahouse Hanford Comoany

J. D. Anderson

N3-13

V. C. Asmund

P7-78

J. A. Demiter

L5-31

D. R. Duncan (3)

H5-33

W. O. Greenhalgh

L5-31

D. M. Johnson

H5-33

R. R. King

P7-70

B. A. Mayancsik

H5-33

M. M. McCarthy

G1.19

M. W. McCoy

P7-68

E. P. Mertens

H5-33

J. G. Riddelle

H5-33

R. J. Roberts

N3-13

J. A. Swenson (2)

G6-45

F. F. Walters

T4-18

Central Files

L.8-04

Document Processing and

Distribution (2)

L8-04

Information Release

Administration

Pecific Northwest Laboratory

PNL Technical Files

K1-11

Distr.1 1 
DATE

FILMED

$8 / 12 / 93$ 